\title{
Recovering Subjects: Investment in an Age of Reconciliation
}

by

Robyn Green

A thesis submit ted to the Faculty of Graduate and Postdoctoral Affairs in partial fulfillment of the requirements for the degree of

Doctor of Philosophy

in

Canadian Studies

Carleton University

Ottawa, Ontario

(C) 2016

Robyn Green 


\title{
Recovering Subjects: Investment in an Era of Reconciliation
}

\author{
Robyn Green, Carleton University
}

This doctoral project examines reconciliation and how Canada's Indian Residential Schools Settlement Agreement (2005) was designed to provide reparations to former students who were harmed in residential schools. In the past three decades, many Indigenous leaders and organizations identified a need for public investment to address historical injustice. In response, settler governments reframe these demands as opportunities for economic investment that are guaranteed to produce self-esteem and social inclusion for Indigenous peoples. This dissertation documents and problematizes an ideological shift whereby demands for redress and restitution give way to an investment rationale that is used to bypass demands for self-determination (Green 2015). Therefore, in this study I ask: how do investment discourses structure Indigenous-settler relationships? What is specific about the application of investment rationale when deployed during redress and reconciliation processes? In order to answer these questions I use a multi-site methodology to examine material and symbolic reparations, such as the Independent Assessment Process, the Truth and Reconciliation Commission, and therapeutic health supports. I draw on governmentality literatures to argue that an investment rationale disciplines individual compensation claimants through categories of harm and legal accounting processes to construct Indigenous subjects as dysfunctional and wage employment as emancipatory. I then examine how Indigenous health supports are subject to disinvestment, which effectively marginalizes Indigenous conceptualizations of health that privilege self-determination. Finally, I explore how the Truth and Reconciliation Commission routinely valorizes "mutually beneficial partnerships" as a template for contemporary Indigenous-settler relationships. My analysis thus contributes to the field of settler colonial studies and reveals how investment rationale is deployed to contain the cost of reparations and to create a politics of exchange where a return can be recovered from monies allotted to reparative strategies. The expected return that is desired by the settler state is, ultimately, the assimilation of Indigenous peoples' into neoliberal citizenship. 
I dedicate my thesis to Nathan Praw, and his mother, Naomi Angel. Naomi had a rare talent for finding triumph in the wake of profound loss. This made her a blessing to all she met. 


\section{Acknowledgements}

I have been told by many people that undertaking and finishing a doctoral project is more about endurance than brilliance. Fatigue sets in early because managing one's time and output is exacerbated by the need to manage one's anxieties, emotions and expectations. It can difficult to keep perspective under such conditions, so I want to extend a thank-you to those who helped me keep mine for the duration of this project.

First and foremost, I want to thank my supervisor Eva Mackey, for both her support and for holding my project to the highest standards, mirroring her own exceptional scholarship. From her, I learned that rigorous research and concise writing can create endless conversations and possibilities. This valuable insight has and will inspire all the academic work I undertake. I would also like to thank my committee member, Jennifer Henderson, whose scholarship has deeply influenced my project. I was always impressed by her powers of foresight and her ability to get to the heart of every argument so precisely. My committee member Nadine Changfoot's feedback, support, enthusiasm and patience were much appreciated throughout the process. Peter Hodgins has always encouraged me to develop my ideas even when I wasn't sure where I was going or if what I wanted to do was possible. He routinely put me back together after my confidence collapsed and could always lighten the darkest of moods.

I would also like to extend a huge thank you to Dr. Dian Million and Dr. Alexis Shotwell who served as examiners of my dissertation. Their feedback and insights gave me interesting perspectives on my current project and will be central to helping me conceptualize my future scholarship.

I also want to acknowledge the unfailing support of my parents, John and Barb, who answered the phone sometimes two or three times a day to listen to my anxieties and stresses. Their emotional and (let's face it) financial support enabled me to complete this project. They both embody such intelligence, grace and tenacity and always gave me an ideal to aspire to. I would also like to acknowledge the support of my sister Barb, my brother(-in-law) Greg and my three nieces Cameron, Holly and Anna, whose happy and hardworking family has always been of great comfort to me.

I also developed another family in the School of Canadian Studies through my friendships with Julie Tomiak, Jeff Ruhl, Danielle Ruhl, Gabrielle Etcheverry, Kelly Black, Andy Thompson and Peter Thompson. Each and every one of you inspired, comforted and challenged me as a scholar and as a person and I would have been lost without your help. I also want to thank the Sociology/PSCI boys: Chris Hurl, Jamie Brownlee, Ajay Parasram and Mat Nelson for great times, frank conversations and conference adventures. And I want to thank Emma Lind for being committed to creating a solid feminist community of two.

To my besties, Neale Macdonald and Kristy Holzworth, I thank you for every phone call, sob and worry that you shared with me. I am so proud of both of you and consider myself infinitely lucky to have had you on my side the whole way through. And to my hometown buddies, Danny 
Riddell and Sherri Ellis, I am excited at the prospect of seeing more often and being more relaxed when I do.

I also want to acknowledge important work colleagues who gave me time off, provided me space to work and always cheered me on: Chris Dornan, Barry Wright, and Chris Brown. It is also important to recognize the day-to-day efforts of Elaine Rouleau who experienced every heartbreak and victory throughout the process right along with me. Having your knowing presence and sympathetic ear in the room next to me did wonders for my mental health and made this project possible.

I would also like to thank some very important academic colleagues that have provided me encouragement and feedback throughout the process, namely, Dr. Andrew Woolford, Dr. Rosemary Nagy, Dr. Pauline Wakeham, and Dr. Karine Vanthuyne.

And finally, I would like to thank Caroline Roulx for reminding me of the importance of keeping perspective and for always helping me to find it. 


\section{Table of Contents}

$\begin{array}{ll}\text { Abstract } & \text { i } \\ \text { Dedication } & \text { ii } \\ \text { Acknowledgements } & \text { iii } \\ \text { Table of Contents } & \text { V } \\ \text { Publishing Notice } & \text { vi }\end{array}$

Chapter 1: Recovering Subjects: Investment in an Era of Reconciliation 1 Residential Schooling $\quad 6$ Genocide and Reparations $\quad 9$

$\begin{array}{ll}\text { The Symbolic and the Material: Transitional Justice } & 13\end{array}$

$\begin{array}{lr}\text { The Consolidation of Settler and Neoliberal Projects } & 17\end{array}$

The Ascendancy of Investment Rationale $\quad 24$

Affecting Investment 33

$\begin{array}{ll}\text { Methodology } & 35\end{array}$

Summary of Thesis $\quad 39$

Chapter 2: The Economics of Reconciliation: Investing in Indigenous-Settler

Relationships $\quad 42$

Depending on Canada: National Investment $\quad 45$

"The Cost of Doing Nothing": Social Investment 53

No Pain No Gain: Therapeutic Investment 66

Conclusion: Investing in Reconciliation 78

Chapter 3: Accounting for Justice: The Indian Residential School Settlement

$\begin{array}{lr}\text { Agreement } & 80\end{array}$

The Politics of Doubt and the Alternative Dispute Resolution Mechanism 82

Taking Action: The Politics of Settlement and Containment 88

Restoring Stakeholders 96

The Indian Residential Schools Settlement Agreement 100

$\begin{array}{ll}\text { Common Experience Payment } & 100\end{array}$

The Independent Assessment Process 106

$\begin{array}{lr}\text { Therapeutic Health Supports } & 109\end{array}$

The Truth and Reconciliation Commission 112

$\begin{array}{ll}\text { Conclusion } & 116\end{array}$

Chapter 4: Employing Trauma: Loss and Capital in the Independent Assessment $\begin{array}{ll}\text { Process } & 118\end{array}$

$\begin{array}{ll}\text { Therapeutic Jurisprudence } & 120\end{array}$

No Points for Guessing: The Medicalization of Abuse 124

$\begin{array}{ll}\text { Employing Trauma } & 138\end{array}$

Economic Development, Reconciliation and Healing 147

$\begin{array}{ll}\text { Conclusion } & 152\end{array}$ 
Chapter 5: Dwindling Investments: Disinvestment, Reconciliation and Health Supports for Indigenous Survivors 155

$\begin{array}{ll}\text { Health, Audits and the Shadow State } & 158\end{array}$

Indigenous-Settler Relations: Mental Health Supports 168

$\begin{array}{ll}\text { The Aboriginal Healing Foundation } & 169\end{array}$

The Indian Residential Schools Resolution Health Support Program 178

Analyzing Disinvestment 185

$\begin{array}{ll}\text { Conclusion } & 193\end{array}$

Chapter 6: "It's not like we are asking you to marry the government": The Politics of Partnership at the Truth and Reconciliation Commission of Canada 196

$\begin{array}{ll}\text { Settling Participation } & 198\end{array}$

$\begin{array}{ll}\text { Reconciliation Talk } & 202\end{array}$

Indigenous-Settler Partnerships $\quad 204$

$\begin{array}{ll}\text { Expressing Reconciliation } & 210\end{array}$

Investing in Affective Partnerships $\quad 212$

$\begin{array}{ll}\text { Forgetting Partnership } & 225\end{array}$

$\begin{array}{ll}\text { Conclusion } & 231\end{array}$

$\begin{array}{ll}\text { Conclusions } & 233\end{array}$

Appendix A: Interview Chart 242

$\begin{array}{ll}\text { References } & 243\end{array}$ 
Parts of this dissertation have already been published in the following articles:

Green, Robyn. 2012. "Unsettling Cures: Exploring the Limits of the Indian Residential School Settlement Agreement”, Canadian Journal of Law and Society 27, 1: 129-148

Green, Robyn. 2014. "Recovering Space: Trauma, Education and The Lesser Blessed" Canadian Literature and Cultural Memory, 354-372. Toronto: Oxford University Press.

Green, Robyn. 2015. "The Economics of Reconciliation: Tracing Investment in Indigenoussettler Relations", Journal of Genocide Research 17, 4: 473-49 


\section{Chapter 1: Recovering Subjects: Investment in an Era of Reconciliation}

Where do you begin telling someone their world is not the only one? (Lee Maracle qted in King 99).

The error lay in the willingness to embrace power and a national policy of assimilation. The issue is not who is responsible, but the fact that authority was not questioned (Department of Indian Affairs and Northern Development 2000, 4).

Residential school policies initiated the removal of Indigenous children from their communities and homelands to attend "educational institutions." These institutions deployed curricula to culturally assimilate Indigenous peoples into the settler society, and in the process, Indigenous children were subjected to widespread abuse and neglect by school administrators (Fiske 2008; Grant 1988; Miller 1996; Milloy 1998). In numerous testimonies and public commissions, the residential school system was cited by many Indigenous peoples as not only damaging to their personal lives but to the relationship between Indigenous peoples and settler Canadians (see Royal Commission on Aboriginal Peoples1996). Stephanie Irlbacher-Fox (2007) has noted that the imposition of residential schooling "set the tone and trajectory of the relationship between the state and Indigenous peoples" (150). This relationship — characterized by violence and mistrust - remains fraught to this day, due to a history of genocidal policies perpetrated against Indigenous peoples by the settler state.

Numerous attempts to "reconcile" the beleaguered relationships between Indigenous peoples and the settler state have occurred over the past three decades. While reconciliation is a concept that has been used to affirm Indigenous peoples' inherent rights to territory, resources and jurisdiction (Henderson, S. 2013; Ladner 2006), it has more recently been taken up in mainstream Canadian society to describe a process that publicly addresses the historical violence committed against Indigenous peoples (Alfred 2005; Coulthard 2014; Ladner and Dyck 2008; Mackey 2013; 
Henderson 2013; Simpson 2012; Turner 2013), especially in relation to residential schooling (Green 2012; Henderson and Wakeham 2009; Million 2013; Nagy 2012; Winter 2012). Taking the multiple definitions of reconciliation into account, my dissertation examines the mobilization of Indigenous peoples' demands for historical justice and how these demands are re-articulated by the settler state. Most instructive in illustrating this discursive confrontation is Henderson and Wakeham's (2009) distinction between reconciliation and redress. These scholars suggest that reconciliation's “more abstract resonances of overcoming differences lend the term to co-optation by governments seeking to cleanse the national image through more symbolic measures," while redress is defined by "aggrieved constituencies' movements from below to achieve state recognition and material forms of compensation for injustices" (15). Building on these definitions, I concur with the prevailing scholarly critique that mainstream and official reconciliation processes run the risk of being co-opted by mainstream settler and neoliberal projects (see Blackburn 2007; Henderson and Wakeham 2009; Green 2012; Mackey 2013; Million 2013; Nagy 2012).

Kanien'gehaga scholar Taiaiake Alfred (2005) also dismisses reconciliation "as a process and a concept [that] is not compelling" (152). He maintains that, instead, resurgence and restitution are more meaningful political goals for Indigenous peoples. As I will demonstrate in the following chapters, calls for restitution that demand extensive capital and land transfer to Indigenous nations are routinely negated by the settler state because they are viewed as an obstacle to accessing Indigenous lands in the pursuit of economic development and profit. Therefore, in this dissertation I advocate for the need for a decolonization of the settler state to inform reconciliation processes if they are to be considered worthwhile (Green 2012; Henderson and Wakeham 2009; Nagy 2012; Park 2014; Regan 2010). According to Joyce Green (2003) decolonization requires "the understanding of the historical colonial process. Then, it requires substantive power-sharing to 
ameliorate the inequitable, unjust, and illegal appropriation of indigenous peoples' territories, resources, and political autonomy," and finally, this process "implies fundamental change in the Canadian federation, constitution, and political culture" (54). ${ }^{1}$ In other words, the acknowledgement of Indigenous autonomy, territorial jurisdiction and the recognition of the nation-to-nation relationship is required if true reconciliation is to take place in Canada (see also Maka and Fleras 2005).

To situate the ascendancy of reconciliation discourse in Canada, I draw attention to a statement made in the Royal Commission on Aboriginal Peoples' Final Report (1996), which noted that there was a "great debt is owing" to Indigenous peoples due to a history of dispossession and oppression, "a debt on which governments and Canadians cannot renege" (55). I present the Royal Commission's use of the language of debt and repayment here to foreground the settler state's role in enacting colonization to engender settler enrichment and assimilate Indigenous peoples. Despite the immense "debt owed" to Indigenous peoples, the settler state routinely deploys what I have labelled investment discourse to ensure a financial return from the reconciliation process. Investment rationale and discourse creates and maintains a politics of exchange where a surplus return is demanded for any money invested. This dissertation is animated by the following questions: how is the settler state's investment rationale and discourse deployed to structure Indigenous-settler relationships? How does this investment rationale negate or subvert Indigenous demands for restitution and decolonization? What is specific about the application of investment rationale when deployed during redress and reconciliation processes?

\footnotetext{
${ }^{1}$ In using Green's definition of decolonization, I do not assert that this is the only definition of decolonization. This process represents an assemblage of projects and practices that range from re-structuring of government systems and policies to the decolonization of the mind. But at the base of each of these different projects is the need to dismantle colonial assumptions and to respect the autonomy of Indigenous epistemologies.
} 
The concept of reconciliation in Canada is strongly associated with the contemporary reparations process. Reparative strategies were designed to acknowledge and compensate for child removal policies, and are implemented and governed through the Indian Residential Schools Settlement Agreement (IRSSA). Briefly, former students or survivors of the residential school system organized to appeal for redress ${ }^{2}$ by launching a series of class action lawsuits against the four administering churches and the federal government in the late 1990s. ${ }^{3}$ The IRSSA was officially negotiated in 2005 when the Cloud v. Canada and Baxter v. Canada class action lawsuits were settled out of court. The court mandated reparations were provided in the form an ex gratia Common Experience Payment, an Independent Assessment Process, a Truth and Reconciliation Commission, health support funding, and monies dedicated to commemoration projects. The Agreement's reparative components were developed from a restorative model of justice "where all stakeholders involved in an injustice have an opportunity to discuss its effects on people and to decide what is to be done to attempt to heal those hurts" that have been inflicted by the perpetrator (Braithwaite 2002, 246). The restorative process was enacted to ensure that Indigenous peoples were the primary recipients of reparations, however, as I have noted above, many scholars have argued that reconciliation processes in Canada continue to advance settler interests because

\footnotetext{
${ }^{2}$ The two main national Survivor Societies are: The National Residential School Survivor Society which has recently been de-funded and whose work is currently associated with the Shingwauk Project located in Sault Ste. Marie, Ontario; and The Indian Residential School Survivor Society, a group based out of British Columbia and currently funded through the Conservative government's Advocacy and Public Information. <http://www.irsss.ca/>

${ }^{3}$ The use of the word "survivor" to describe former students of residential schools has been publicly debated. The term has been used primarily by public organizations (such as the Assembly of First Nations) that have brought together former students of the residential school system to initiate settlement and health support programs. The Truth and Reconciliation Commission is also governed by an Indian Residential School Survivor Committee and its members primarily represent all former students of this system. Nevertheless, the Chief Commissioner of the Truth and Reconciliation Commission of Canada, Murray Sinclair, has expressed discomfort with this terminology, stating in a much publicized Facebook post that former students have accomplished much more than "survival" in the wake of historical injustice.
} 
reparations are enacted through settler law (Blackburn 2012; Henderson and Wakeham 2009; Green 2012; Mackey 2013; Million 2013; Nagy 2012; Regan 2010).

I argue that, in spite of the demands for restitution and socio-economic justice made by Indigenous peoples, investment rationale disciplines reparation strategies. I argue that reparative strategies govern Indigenous peoples “at a distance” (see Rose 1999) in order to subvert decolonial goals and maintain the continuity of corporate investment and capitalist accumulation from the reparations process. Therefore, I argue that investment rationale is a symptom of converging settler and neoliberal governmentalities that are operationalized in diverse and contradictory ways (see also Blackburn 2012; Henderson 2013; Mackey 2013; Million 2013). Investment rationale is mode of governance that is circulated not only as a means to "default" on reparative debt, but it is also used to ideologically shift the conceptualization of settler indebtedness. The responsibility for settler debt is shifted to Indigenous peoples through the provision of reparations, by making the reception of reparations dependent (or conditional) upon the demand for neoliberal citizenship.

Using the lens of "investment" discourse to analyze the reconciliation process, I document how reconciliation processes financialize problematic histories and bodies to ensure prosperous outcomes for the nation-state and the Canadian taxpayer. Given the complexity of the IRSSA, in this dissertation I deploy a multi-site approach to determine how reparations strategies mobilized across multiple modalities such as legal frameworks (compensation), quasi-judicial processes (Truth and Reconciliation Commission of Canada) and public policy (health supports) are subject to capitalist modes of exchange. Specifically, I document how reparations were designed to accomplish two things: to contain or limit the parameters of reparations, and to encourage claimants to make an economic contribution to the settler state after receiving reparations. I examine how investment rationale was applied to the implementation of the Indian Residential 
Schools Settlement Agreement so as to contain the exorbitant expense of redress through predetermined class eligibility, non-negotiable deadlines and compensation frameworks designed to calculate reparations for a decipherable number of claimants and compensatory awards. While the Agreement provided the settler state with an opportunity to budget for reparations, investment rationale is deployed to discipline individual claimants by "accounting" for and quantifying their suffering and loss within compensation frameworks; to discipline organizations through institutional evaluation and audits, such as in the case of the Aboriginal Healing Foundation; and to discipline Indigenous-settler relations writ large by emphasizing the importance of partnership at Truth and Reconciliation Commission National Events. I also examine how neoliberal and settler ideologies are fully supported by "structures of feeling" (see Gordon 2010; Ventura 2012) that encourage Indigenous peoples to live happy and healthy lives as a duty of said citizenship. Taking these observations into account, the ongoing need for the settler state to benefit from the reconciliation process calls into question the spirit of justice enacted through the Agreement.

\section{Residential Schooling}

Residential schooling — enacted through a set of principles embedded in the Indian Act (1876) - led to the removal of over 150,000 children from their homes, communities, and families, who were then placed in "educational" institutions. Upton argues that "the policy of assimilation was the result of a concurrence of sentiment and interest: the sentiment that a superior race (the British) had definite responsibilities towards an inferior (the Indians) coincided with the selfinterest of the British government in cutting the costs of colonial administration"' (quoted in Wotherspoon and Satzewich 2001, 16). By tempering a civilizing rationale with a cost-effective strategy, residential schooling was designed to integrate and assimilate Indigenous peoples into a 
wage economy. For this reason, the portfolio of education would prove to be useful in acts of dispossession and the destruction of community.

Residential schooling was introduced through a set of legislation implemented in the Indian Act (1876), following the policies initially instituted in the Gradual Civilization Act (1850). The Indian Residential School system became enshrined in this legislation, making the attendance of residential school mandatory for all Indigenous children by 1920. Parents unwilling to comply with mandatory schooling were subject to arrest and imprisonment. At first, "residential schools originally operated as day schools, but administrators felt that the children's returning to their parents at the end of each day was undoing their day of lessons in the proper conduct of 'civilized' persons" (Woolford 2005, 85). Thus, these schools became "total institutions'...where a large number of people lived and worked together cut off from both the wider First Nation and mainstream societies" (Assembly of First Nations 1994, 3), and the student's life was 'determined and controlled"" by school authorities (Llewellyn 2008). ${ }^{4}$ The geographic isolation of these institutions and their relative neglect by government and police agencies were factors that contributed to crimes of the most egregious nature taking place in Canada's residential schools. Increasingly, the educational system was likened to a punitive system of its own. For instance, Rymhs (2006) states that "[i]n its forced relocation and confinement of indigenous children, the residential school was historically a precursor to the prison system in Canada, used to control or contain Aboriginal subjects for colonial as well as penal purposes" (112). ${ }^{5}$ In fact, one could argue

\footnotetext{
${ }^{4}$ Wotherspoon and Satzewich (2000) caution that employing the concept of "total institutions" may deny the presence of Indigenous resistance in the schools, which was very prevalent (35, see also Grant 1988). However, I use this term to demonstrate the legal constraints placed on Indigenous peoples and their families, which is marked by mandatory attendance and parental imprisonment upon refusal to send their children. Moreover, former students indicate that life within the schools was highly regimented and that they were always under surveillance by caretakers.

${ }^{5}$ I also want to take note of how the Department of Indian Affairs and Northern Development has said that individuals' experiences in residential schools was "not unlike" that of "individuals who have been imprisoned or who have been confined to psychiatric institutions" (Wotherspoon and Satzewich 2000, 35).
} 
that high volumes of incarceration in Indigenous communities can be directly related to the closure of residential schools.

Children placed in Canada's Indian Residential School (IRS) system experienced various forms of violence, including but not limited to their subjugation to a curriculum replete with assimilationist logics designed to demonize Indigenous epistemologies and practices (see Chrisjohn and Young 1997; Furniss 1992; Grant 1988; Milloy 1999; Woolford 2004). ${ }^{6}$ This institutionalized form of what Battiste (2000) refers to as "cognitive imperialism" is argued to have shattered familial and community relationships by undermining parental and elder authority (Green 2014, 356). Likewise, Julien Walker (2009) suggests that because

students were prohibited from speaking Aboriginal languages or practicing their cultures, both in and out of the classroom setting... [and because they] were often physically punished or humiliated if they were found to be speaking their native language or to be practising their traditional faiths... [there has been] a drastic decline of Aboriginal languages in Canada, and many of those that remain are not expected to survive much longer as the only fluent speakers in some communities are elders. (6-7)

In other words, cognitive imperialism is considered to be a main source of former students' traumatic loss, which is constituted by "loss of identity, loss of family, loss of language, [and] loss of culture" (Legacy of Hope 2010, 2).

Narratives of emotional and physical abuse and loss of culture are common in popular and academic accounts of residential schools. Less common are discussions about how this system was designed to ensure the dispossession of Indigenous peoples from their lands. In this regard Bonita Lawrence's (2003) work is pivotal. She notes that as communities were emptied of their youth and students lost their Indian status as a result of residential schooling, it became evident "that the colonial act of establishing legal definitions of Indianness...has enabled the Canadian government

\footnotetext{
${ }^{6}$ Only recently has it been revealed is that the Canadian government used residential schools as sites for medical and scientific experiments, and that at least 3000 students died as a result (see Mosby 2013).
} 
to remove a significant sector of Native people from the land" (Lawrence 2003, 6). Drawing a further correlation between the IRS system and dispossession, de Leeuw (2007) notes that

[t]he 1845 Bagot Report also contains links between colonial education of Aboriginal children and their dispossession from their lands. The government, the commissioners argued, had a moral and protectionist duty to ensure Aboriginal peoples became acclimatized to Eurocolonial expectations of civilization, including agricultural proficiencies and settlement on delineated, privately owned properties. (71)

Indigenous youth were expected to leave their communities and take up residence and employment in predominantly white society.

The Royal Commission of Aboriginal Peoples' Final Report (1996) also asserts that "[r]esidential schools were more than a component in the apparatus of social construction and control. They were part of the process of nation building and the concomitant marginalization of Aboriginal communities" (Vol. 1, 310). Similarly, the Truth and Reconciliation Commission of Canada's Interim Report (2012) concludes that "[w]ith assimilation would come the breaking up of the reserves and the end of treaty obligations. In this way, the schools were part of a broader Canadian policy to undermine Aboriginal leaders and Aboriginal self-government" (26). In presenting the history of residential schooling in this way, I point out how the growth of Canadian industry and nationhood was indelibly linked to the "education" of Indigenous peoples.

\section{Genocide and Reparations}

Drawing on the work of scholars who theorize the genocidal implications of settlement in Australia (see Wolfe 1999; Moses 2004; Short 2005), Canadian scholars have sought to advance the argument that residential schooling constitutes an act of genocide (see Green 2015; MacDonald 2015; Neu and Therrien 2003; Woolford and Benevento 2015). The role of the settler state in committing a genocide against Indigenous peoples in Canada has become a source of public discussion and debate; however, these discussions routinely become mired in the legal definitions 
of genocide or whether a case of this nature can plausibly win recognition in an international forum. ${ }^{7}$

I suggest that residential schooling should not be considered to be a single genocidal legislation, but as one example of the systemic violence imposed on Indigenous peoples following settlement. Residential schooling was exercised in concert with other genocidal acts such as dispossession, environmental degradation, relocations, child welfare removals, the murder of Aboriginal women and the subsequent neglect of the victims by police personnel, and the notably high incarceration rates for Indigenous individuals.

To help understand the breadth and contradictions of genocide, I theorize settler colonialism in Canada through the concept of coloniality. Functioning as an assemblage of different practices, coloniality operates through the twin processes of capitalist accumulation and the social construction of race, the combination of which is most aptly described as the coloniality of power (Maldonado-Torres 2007, 243-4). ${ }^{8}$ Functioning as a portmanteau of modernity and colonialism, Ramon Grosfoguel (2007) asserts that "coloniality is not equivalent to colonialism. It is not derivative from, or antecedent to, modernity. Coloniality and modernity constitute two sides of a single coin" (219). Coloniality represents a matrix of power that affirms European knowledges, languages and forms of governance in an effort to supplant Indigenous systems of knowledge, in order to construct intricate structures of privilege that secure the larger processes of capitalism, patriarchy, and heteronormativity. Through this understanding of coloniality, which

\footnotetext{
${ }^{7}$ Human Rights lawyer Bernie Farber and former National Chief of the Assembly of First Nations and proponent of the Indian Residential Schools Settlement Agreement, Phil Fontaine routinely advocate for the recognition of the residential school system as a genocide by the International Criminal Court (Fontaine and Farber 2013; Fontaine, Dan and Farber 2013).

${ }^{8}$ Anti-colonial and subaltern thinkers have been heavily influenced by the Marxist tradition, or historical materialism, in their assessment of the colonial system. While acknowledging the dynamics of power and the social construction of race, these thinkers understand the relationship between social oppression and the globalization of the capitalist economic system as a universal force in maintaining colonial systems.
} 
situates colonialism and modernity as co-constitutive, the benevolence of the modern civilizational processes is interrogated due to its intimate attachment to unsavoury and violent practices such as dispossession, slavery and genocide.

Conceptualizing settler colonialism through the lens of coloniality makes it difficult to confirm genocide because of the legal definitions stipulated by the oft cited Convention on Genocide. ${ }^{9}$ Therefore, I suggest that Dean Neu and Richard Therrien's book Accounting for Genocide: Canada's Bureaucratic Assault on Aboriginal People (2003) serves as a useful and instructive framework for understanding genocidal violence in Canada. These scholars make a correlation between Canadian bureaucratic practices and regimes such as Nazi Germany by employing a Foucauldian lens to analyze how accounting techniques and rationality constitute a technology of genocide. Their scholarship provides an inventory of accounting practices that document how land claims, economic development policy, and residential schooling all exercised “cost-cutting and other numerical 'solutions"” (Neu and Therrien 2003, 7) to ensure the supremacy of settler state authority over Indigenous peoples. Repressive accounting techniques also "serve to structure the condition of possibility within a particular institutional field" ${ }^{10}$ and "not only frame potential problems within the field, but also construct possible solutions" (Neu and Heincke 2004, 181). Therefore, accounting techniques constitute "a way of seeing society" that presupposes that "the current socio-political order is taken to be at least legitimate" (Gallhofer and Halsam 2003, 2). For these reasons, scholars have also noted that "accounting's role in imperial and colonial

\footnotetext{
${ }^{9}$ The Convention on the Prevention and Punishment of the Crime of Genocide, Article II defines genocide in the following way: "any of the following acts committed with intent to destroy, in whole or in part, a national, ethnical, racial or religious group, as such:(a) Killing members of the group; (b) Causing serious bodily or mental harm to members of the group; (c) Deliberately inflicting on the group conditions of life calculated to bring about its physical destruction in whole or in part; (d) Imposing measures intended to prevent births within the group; (e) Forcibly transferring children of the group to another group" (Fontaine, Dan and Farber 2013, n pag.).

10 The exploration of repressive accounting techniques emerged in the field of governmentality studies (see Hopwood 1990; Miller and Napier 1993)
} 
practices amounts to the seeking of imperialistic domination by Western states and related regulatory practices" (Galhofer and Chew 2000, 262). ${ }^{11}$ Indigenous forms of governance are subsumed under Eurocentric forms in order to regulate Indigenous bodies, identities, political and spatial behaviours. I argue that these practices constitute genocidal acts even if they are not defined as such through the Convention on Genocide.

In this study, I also note that accounting can also have an emancipatory role, especially in the context of documenting the legacy of genocide and in the process of extending reparations. This form of accounting "reflects a concern to express a critique of the social structure, to counter the institutional constraints and to draw attention to negative dimensions of social and organisational functioning that inhibit exposure of the interests of the exploited," and serves to "monitor what matters to people whether material or non-material, financial or non-financial" (Gallhofer and Haslam 2005, 159). In her 2015 book, Who Counts: The Mathematics of Death and Life after Genocide, Diane Nelson explores how numbers and quantification were used to generate numbers and percentages of people who had been victimized during the Guatemalan civil war and to identify acts of perpetration. She also documents how accounting techniques were used to establish reparations for former students or for family members whose lives had been lost. She states that accounting "has provided important leverage for struggles to make people and institutions accountable - to accept responsibility for their actions" (Nelson 2010, 89). Nelson (2015) argues that the relationship between accounting for genocide and accounting for reparations is a form of "double-entry accounting," that establishes "parallel columns of debt and credit, injury

\footnotetext{
${ }^{11}$ Several scholars have traced the application of accounting techniques to Indigenous-settler relations (Galhofer and Chew 2000; Gibson 2000; Greer and Patel 2000; Neu 2000; Neu and Therrien 2003), however, there is little use of First Nations, Inuit and Métis authors to conceptualize colonialism, and the theorization of "Indigenous accounting techniques" is tantamount to a facile anthropological exploration of Indigenous practices in opposition to Western authority.
} 
and repair" (14-16). Therefore, accounting techniques are deployed to reveal the damages caused by acts of genocide and to calculate compensation. The double-entry bookkeeping metaphor employed by Nelson astutely demonstrates the importance of accounting in acknowledging loss and perpetration, but she also warns her readers that numbers may obscure more than they reveal. ${ }^{12}$

This latter point is taken up by other scholars who have suggested that the accounting practices that are used in aftermath of violence or disaster and in calculating reparations can become "less focussed on alleviating suffering and become more concerned with traditional [economic] ends," such as "the reduction of fraud, improved financial accountability and the prediction of future uncertainty" (Saragiacomo et al. 2014, 577). So, accounting techniques that are employed as an emancipatory tool can be used to subsume reparations and compensation under market relations.

In this section, I have documented how repressive accounting techniques can constitute a genocidal practice, but I have also identified how accounting techniques can create a pathway to reparations for victims of genocide and state violence. However, I stop short of a full endorsement of emancipatory accounting because I address the potential for slippage into repressive practices. In returning to Neu and Therrien's (2003) work as a point of entry for the Canadian case study, I ask whether the same technologies that are used to enact genocide against Indigenous peoples are now being used to repair the outcomes of genocide and, if so, what "strings" are attached to reparations once they are received?

\section{The Symbolic and the Material: Transitional Justice}

\footnotetext{
${ }^{12}$ As an anthropologist, she conducted numerous interviews with victims of state violence. Her analysis tends to focus on how recipients of reparations tend to interpret their feelings and emotions after receiving money in exchange for the loss of loved ones.
} 
A substantive amount of scholarship documenting the possibilities and limitations of reparations has been written in the last decade. According to Elazar Barkan (2001), "reparations refer to some form of material recompense for that which cannot be returned, such as human life, a flourishing culture and economy, and identity" (xix). Some transitional justice scholars have argued that the provision of compensation monies to victims function as an important practice in confronting histories of injustice and trauma (Barkan 2001; de Grieff 2006; Minow 1998; Torpey 2006). Brandon Hamber (2000) asserts that "granting reparations can add value to the "truthseeking' phase" of redress and TRC processes, "insofar as it can affirm that the values and interests, as well as the aspirations and rights, of those who suffered are being advanced" (218). Preferably, the acknowledgement of wrongdoing should be followed by a concerted effort to address how historical injustice has impeded the material lives and livelihoods of victims. Assembly of First Nations legal representative Kathleen Mahoney, states that in organizing redress for residential schools claimants, "[t]he money was not the number one consideration" because "for many people, the apology and healing initiatives are the most important" reparative elements (quoted in Popic 2007, 15). Nonetheless, Claire Moon (2012) cautions that "reparations can also function as a mechanism that attempts to placate victim demands for criminal justice and regulate the range of political and historical meanings with which the crimes of the past are endowed and through which they are interpreted" (2). Moon's point introduces an important question relating to the legitimacy of providing reparations to former residential school students.

She goes on to note that scholarly analyses of reparations primarily focus on the "popular practical and analytical distinction between 'material' and 'symbolic' reparations" (Moon 2012, 4). Invoking Raymond Williams, Moon suggests that the material and symbolic aspect of reparations are "indissoluable" because "this distinction, symptomatic of the enduring dualisms 
grounded in Enlightenment thought, is rendered immediately nonsensical at the moment of reception of reparation, at which point the symbolic freight of the material gesture is rendered immediately visible" $(2012,4)$. The separation of the material and symbolic pervades transitional justice scholarship, but in agreement with Moon, I assert that this distinction is not helpful in the analysis of the Canadian reconciliation process. In the comparative analysis of global reconciliation programs, transitional justice scholars have primarily theorized the shortcomings of reconciliatory justice through a lens of scarcity or loss. While many scholars have noted that it is impossible, and even offensive, to compensate loss and suffering with money (see Eng and Kazanjian 2003; Hamber 2009; Minow 1998), they have also argued that a dearth of material reparations is considered the primary reason that reconciliation processes are routinely deemed ineffective (see Humphrey 2005; Short 2005; Torpey 2006). Reconciliation processes with few material reparations are theorized as being merely symbolic, and therefore, only successful at establishing positive public relations for perpetrators.

Others scholars worry that if the reconciliation process in Canada emphasizes only symbolic goals, this will lead to "unwarranted closure" (Blackburn 2007), incomplete resolution (Martin 2009), or a reliance on therapeutic narratives (Green 2012; Henderson and Wakeham 2013; Million 2013), all of which function as a way to absolve the settler state of "historic" violence that has been (and continues to be) committed against Indigenous peoples. Symbolic goals are also believed to undermine commitments to substantive structural change (see Green 2012; James 2013; Nagy 2012; Park 2015), which is particularly worrisome since Canada already functions as a site of non-transition having already realized the goal of liberal democracy (Jung 2009). Stated more clearly, many comparative reconciliation processes are enacted to ensure that democratic authority is established after the dominance of authoritarian regimes (ie Argentina's 
military government; South African apartheid), however in Canada, the average citizen is supposedly already afforded these coveted "freedoms" that are assumed to be tantamount to justice (see also Million 2013, 148). ${ }^{13}$ Therefore, in Canada, a celebration of liberal values embedded in reconciliation processes may serve to attenuate reparative acts and strategies.

I assert that any analysis of the Canadian reconciliation process must also take into account the robust material reparations that were extended through the Indian Residential Schools Settlement Agreement. This IRSSA includes two forms of compensation available to over 80,000 claimants as well as access to health supports and a truth and reconciliation commission (Aboriginal Affairs 2016, n. pag). Before the Indian Residential Schools Settlement Agreement concludes its mandate, over five billion dollars will have been dedicated to the process of reconciliation and the extension of reparations to former students of the residential schools (Curry 2011; Galloway 2012). Therefore, the concerns over scarcity that are so prevalent in analyses of other global reconciliation processes don't apply to Canada. In relying on a frame of material scarcity, scholars may unwittingly equate the extension of material reparations with the realization of justice. What is of primary importance to the analysis of the Indian Residential Schools Settlement Agreement is to avoid confusing the extension of material reparations with restitution or substantive structural change (see Alfred 2009 a). My analysis builds on the analysis of legal scholar Kent Roach (2014), who suggests that the reparations process in Canada has sacrificed distributive justice, which is "concerned with the distribution of resources throughout society" for corrective justice, which "achieves justice by repairing the wrongs that one individual does to another" (572). Taking these caveats into account, I ask: what are the consequences of extending

\footnotetext{
${ }^{13}$ As Million (2013) notes, freedom is conceptualized through the "consumer citizen" who has "many choices that he or she makes in daily relations with corporate advertising affectively attuned to both produce and serve desires"(148).
} 
material forms of recompense to victims of historical injustice? What does the settler state expect from Indigenous peoples when material reparations have been provided?

To begin to answer some of these questions, the next section demonstrate how Indigenous peoples' demands for justice and redress have become imbued with certain values emanating from settler and neoliberal projects that have changed their meaning and application.

\section{The Consolidation of Settler and Neoliberal Projects}

As I argued in the previous section, the separation of symbolic and material recompense after historical injustice is a problematic distinction. Particularly, the implementation of material reparations at this historical moment requires analysis because the consolidation of settler and neoliberal projects in Canada has reached ascendancy in the last two decades. The increased consolidation of settler and neoliberal projects in Canada has particular ramifications for the governance of Indigenous-settler relations (see Blackburn 2012; Green 2012; James 2013; Mackey 2014; Million 2013; Henderson 2013; Tomiak 2011). The overlap of settler and neoliberal projects is revealed in instances where the settler state is preoccupied with ensuring that assimilative projects are efficient and "cost-effective" (Milloy 1996; Turner 2006) and designed to accumulate capital for the nation-state (Gordon 2010; Satzewich and Wotherspoon 2000). At the same time, neoliberalism has been characterized as an economic doctrine that seeks to "eliminate" alternatives to market capitalism (Mignolo 2011; Gibson-Graham 2006), and can therefore be described as powerfully assimilative.

First and foremost, it is important to note that the locus of the coloniality of power in Canada is the settler state. Mainstream Canadians commonly assume the nation-state to be a bastion of liberal justice for all citizens (see Green 2001; Mackey 1999). Nonetheless, Joyce Green (2001) observes that while "the majority of people [in Canada] identify as citizens of the state, the 
human rights of which the government is expected to protect," for Indigenous peoples the state is viewed "as an oppressor that has been economically and politically strong at the direct expense of Aboriginal nations" (Green 2001, 716). For this reason, Paul Nadasdy (2003) conceptualizes the Canadian settler state as "an ideological project" that "confers legitimacy upon the complex constellation of government institutions and processes that have many different (and often contradictory) agendas and interests" (4). ${ }^{14}$ To understand the practices of the settler state, I employ James Scott's (1998) theory of "seeing like a state" to reveal how the goals of public law and policy are presented as mechanisms for establishing the common good, but are actually designed and implemented to retain power for the state and corporations. ${ }^{15}$ By interrogating settler state authority, I reveal a form of governance sustained by what I consider to be a consolidation of settler and neoliberal governmentalities that function to suppress Indigenous peoples' self-determination and jurisdiction.

This project also explores how Indigenous-settler relations are governed in Canada, and is therefore a contribution to governmentality studies because I follow Rose and Miller's method of examining "[t]he actual mechanisms through which authorities of various sorts have sought to shape, normalize and instrumentalize the conduct, thought, decisions and aspirations of others in order to achieve the objectives they consider desirable" (Rose and Miller qted in Neu 2000a, 278). In this section, I trace two different forms of governmentality: a) settler governmentality as

\footnotetext{
${ }^{14}$ In keeping with this conceptualization of the settler state, Joyce Green refers to Project Canada as a "state constructed from the colonies by colonial and then settler elites, evolving but firmly grounded on the original and continuing appropriation of Indigenous land and resources, and built on racist and sexist practices that create the forms of privilege that dominate the state today" (Green 2001, 716).

${ }^{15}$ Critics of James Scott, namely Timothy Mitchell (2006) and James Ferguson (2005), suggest that Scott employs a facile contradistinction between state oppression and "peasant" resistance. As Foucauldian scholars, Mitchell and Ferguson do not view the state as monolith but theorize its presence in the daily lives of individual citizens. Nonetheless, the centrality of the state in enacting various forms of oppressions in relation to Indigenous peoples cannot be denied, and therefore, I still find Scott's work is instructive in demonstrating the power relations embedded in Indigenous-settler governance.
} 
employed to regulate and discipline Indigenous bodies and spaces through policy and settler law, and b) neoliberal governmentality as a set of practices deployed to ensure that public governance is transformed into a corporate model.

To begin, I draw attention to the most obvious example of settler governmentality (Moreton-Robinson 2009; Lindroth 2014; Neu and Therrien 2003; Monaghan 2011) which can be linked to a set of policies and practices that is called the Indian Act (1876). This legislative framework "specifies who is an Indian for entitlement purposes, where they may live, and what they may do" (Maaka and Fleras 2005, 18) and has been used to deny the treaty process and the nation-to-nation relationship established through the Royal Proclamation of 1763. Instead, under the Indian Act (1876), Indigenous peoples were locked into a paternalistic and hierarchical relationship where both their identity and their whereabouts were under constant scrutiny from representatives of the settler state. The residential school system was overseen directly by Indian Act (1876) authority. It is important to note that settler governmentality extends beyond the reaches of Indian Act (1876) legislation to public policy practices, the modern treaty system, ${ }^{16}$ and juridical negotiations (see Diabo 2012).

Attempts to eradicate Indian Act (1876) legislation in the past have been controversial because of fears that existing Indigenous rights would be nullified as part of a larger assimilative approach. ${ }^{17}$ However, Indigenous peoples have presented alternatives to the Indian Act (1876) that would involve implementing "a principled framework for [Indigenous peoples and settler Canadians] 'living together differently"' (Maaka and Fleras 2005, 12). This framework conceives

\footnotetext{
${ }^{16}$ Modern treaties are generally settled through one of two state sponsored processes, Specific Claims Process and the Comprehensive Claims process. Several Northern Dene and Inuit governments have been established through this process to greater or lesser success.

17 There were at least three main instances in the $20^{\text {th }}$ century where Indian Act reforms were proposed: in the 1920s, in 1946 which led to massive changes in the legislation of 1951, and in Trudeau's 1969 "White Paper".
} 
of "an innovative, if unorthodox, pattern of belonging that endorses the notion of nation-states as sites of multiple yet interlocking jurisdictions, each autonomous and self-determining yet sharing in governance of the whole" (Maaka and Fleras 2005, 12 emphasis mine). Indigenous land and treaty rights are an inherent aspect of Indigenous nationhood, and therefore jurisdiction retains a self-determining function because it "is a claim to governance that refers to the legal relationship between a politically organized community and their space" (Pasternak 2013, 3). In short, jurisdiction refers to "the how of governance" (Valverde quoted in Pasternak 2013, 3-4, emphasis Pasternak) and demarcates who makes crucial decisions governing the everyday life of Indigenous peoples in a particular territory. As I will demonstrate in Chapter Two, reconciling Indigenoussettler relationships through an extension of Indigenous jurisdiction has been conceived by the state as a threat to Canadian sovereignty and economic interests.

The denial of jurisdiction is routinely supported by neoliberal doctrine. Neoliberalism represents an economic and political rationale that relies on the logic of market relations to render political, legal or bureaucratic functions of the nation-state equitable and efficient (Larner 2000; Mitchell 2006; Peck and Ticknell 2002; Rose 1999). Neoliberalism generally appears in two forms: roll-back neoliberalism, which is oriented towards spending cuts and privatization, and rollout neoliberalism, which engenders and reproduces particular values, such as individualism and accumulation, to determine "appropriate" behaviours for citizens to embody (see Graefe 2005). According to David Harvey (2005), neoliberalism celebrates a concentration of wealth and is particularly unsympathetic to citizens relying on public institutions to maintain a suitable standard of living. Therefore, a consequence of neoliberal logic is that "regimes of public investment and finance" have begun "to mimic these marketized conditions" (Peck and Ticknell 2002, 385). As service provision is privatized and downloaded, the neoliberal system encourages "people to see 
themselves as individualized and active subjects responsible for enhancing their own well-being" (Larner 2000, 13). As social welfare is increasingly redefined through capitalist logic, individuals who receive support from the state are increasingly required to "give back" to the nation-state alongside and in exchange for the receipt of such support. Since social welfare was designed to address the shortfalls and crises embedded in capitalism, its co-optation by market relations is particularly troubling in an era of reconciliation and reparations, where the economic oppression of racialized peoples goes unchecked under the logic of "bootstrap capitalism"18 in order to shore up a "possessive investment in whiteness"19 (see Lipsitz 2006) that privileges the pursuits and interests of white citizens.

Instead of granting Indigenous groups an extension of jurisdiction, Indigenous scholars have traced the co-optation of self-determination and self-governance demands by settler state authorities (see Alfred and Corntassel 2005; Coulthard 2014; Green 2001; Ladner and Dyck 2008; Million 2013). For instance, Dian Million (2013) has observed that "nations such as Canada often pose self-determination as self-management" in order to adapt Indigenous nations "to capitalist realities" (150 emphasis mine). The process of adapting Indigenous peoples' goals to capitalist demands is considered by Julie Tomiak (2011) to be a neoliberal approach to governance, tantamount to a "reinvention of settler-colonial logic" (7) that functions primarily through acts of individualization and depoliticization. Wendy Brown (2006) suggests that depoliticization

\footnotetext{
${ }^{18}$ David Stoesz's book, A Poverty of Imagination: Bootstrap Capitalism, Sequel to Welfare Reform (2000), examined the ineffectiveness of welfare strategies in the United States. He suggests that these policies produced generational dependence on social services as opposed to emancipation from poverty. He concludes that the welfare system should be redesigned to reflect capitalist rationale and outcomes to enhance its utility and success. Stoesz's analysis focuses on the individual experiences of welfare recipients, and therefore, fails to acknowledge the role of capitalism in producing, legitimizing and maintaining inequality systematically.

${ }^{19}$ In his book The Possessive Investment of Whiteness: How White People Profit from Identity Politics (2007), Lipsitz provides an inventory of policies and procedures that were employed by financial institutions as well as government and municipal agencies to privilege the growth and prosperity of white communities and to undercut the wealth and sustainability of black communities.
} 
"involves construing inequality, subordination, marginalization, and social conflict, which all require political analysis and political solutions, as personal and individual on the one hand, or as natural, cultural, or religious on the other" (15). An analysis of the depoliticization of socioeconomic issues is pertinent to the study of social justice and reconciliation because this form of critique reveals how large scale processes can be used to reproduce settler and neoliberal goals that have been used to constrain Indigenous self-determination.

Neoliberal governmentality is therefore characterized by the economization of the social.

This process means that

[s]ocial government must be restructured in the name of economic logic, and economic government must create and sustain the central elements of economic well-being such as the enterprise form and competition. As this advanced liberal diagram develops, the relation of the social and the economic is rethought. All aspects of social behaviour are now reconceptualised along economic lines - as calculative actions undertaken through the universal faculty of choice. Choice is seen to be dependent upon relative assessments of costs and benefits of "investment" in the light of environmental contingencies (Rose 1999, 141-2).

The economization of the social can primarily be traced through the deployment of economic discourses and calculative techniques in the appeal for social justice and in the responses provided by the state. For instance, the redefinition of social justice along economic lines has forced Indigenous peoples to use the language of the dominant power to appeal for social change. For instance, Jennifer Henderson $(2013,68)$ has documented how organizations such as the Native Women's Association of Canada are now using discourses of investment and economic development to advocate for gender equality. While Henderson (2013) notes that this approach is creative and possibly productive for the organization and Indigenous women writ large, these demands function in "the context of the governing order in which legitimate equality demands must be framed as demands for equality of opportunity to compete" (69). When Indigenous peoples use the language of capital to articulate their goals, the outcomes of social justice are 
determined by capital as well. For example, a 2003 document released by the federal government, entitled Resolving Aboriginal Claims: A Practical Guide to Canadian Experiences, states:

Together with Aboriginal peoples, the Government of Canada is transforming the approach to indigenous issues from an earlier focus on "rights" and "grievances"; into an integrated approach to quality of life, encompassing economic development, human capital, community infrastructure and governance (Indian Affairs and Northern Development 2003, 2-3).

This excerpt from Resolving Aboriginal Claims (2003) exemplifies how state accountability to Indigenous peoples is determined through economic outcomes and the cultivation of public "wellbeing". Not only does this ensure the dominance of capitalist logic in the process of making public grievances, it also assures the marginalization of Indigenous knowledge.

Indigenous peoples have routinely demanded substantive public investment and restitution for historical injustice and ongoing inequality within the Canadian system. For Indigenous-settler relationships to be "reconciled" in a fair and just manner, the settler state must be invested in decolonial goals. Taiaiake Alfred (2009 a) notes that

without massive restitution made to Indigenous peoples, collectively and as individuals, including land, transfers of federal and provincial funds, and other forms of compensation for past harms and continuing injustices committed against the land and Indigenous peoples, reconciliation will permanently absolve colonial injustices and is itself a further injustice. (165)

According to Alfred, massive land and capital transfer are required to ensure that reconciliation is exercised in good faith. Securing jurisdiction alongside these transfers "requires the restructuring of current state policies and practices" and the "substantive restitution and redistribution of wealth" (Tomiak 2011, 8) as the only pathway to affirming the nation-to-nation relationship.

In this section I have documented how the settler state has employ certain practices and tactics to reinforce settler and neoliberal logics in the public sphere. I consider the convergence of settler and neoliberal projects through the lens of "white paper neoliberalism," which is a logic 
that is "committed to the elimination of Indigenous nations as nations, but represents an ideology that seeks to do so through the economization of the social and the normalization of the primacy of private interests" (Tomiak 2011, 288). The consolidation of these two projects is particularly important to the deployment of reparations because the demand for substantive structural change, reparations and restitution has coincided with a historical moment where funding cuts are rampant and the atomization of society has meant that individuals are increasing being made responsible for their own well-being. For this reason, in the next section I argue that the extension of reparations to Indigenous peoples was not only employed to absolve the settler state of responsibility or to realize the symbolic goal of positive public relations: but the settler state utilized reparations to secure a financial (and emotional) return for the settler state.

\section{The Ascendancy of Investment Rationale}

The Royal Commission of Aboriginal Peoples Final Report (1996) noted that a post-World War I audit of Department of Indian Affairs stated that "Indian expenditures were ' $a$ good investment"' (Vol. 1, 310 emphasis mine) because assimilative policies ensured that Indigenous peoples would contribute to the settler state through the wage economy and increased tax revenue. The expenditures - most notably the imposition of residential schooling - were enacted to accelerate land dispossession and fill menial labour shortages in the mainstream Canadian economy (see de Leeuw 2007; Gordon 2010), effectively situating the settler state as the primary beneficiary of this "investment." ${ }^{20}$ I suggest that the residential school system represents a disciplinary investment employed by the federal government to support the intense regulation of Indigenous bodies and behaviours through "training" and "education" in an effort to enact

\footnotetext{
${ }^{20}$ According to the Aboriginal Healing Foundation, the Government of Canada spent approximately 1.5 billion dollars maintaining 130 residential schools between 1877 and 1965 (Castellano Vol. 1 2006, 208).
} 
assimilative outcomes. Situating residential schools as a disciplinary investment for the settler state contradicts popular narratives of misplaced settler benevolence.

During the 1950s and 1960s, spending on assimilative projects such as residential schooling became increasingly unpopular. Government officials and taxpayers viewed large scale assimilation projects as having failed to integrate Indigenous peoples into mainstream Canadian society and instead produced a climate of economic dependency and poverty in Indigenous communities. In a government commissioned study on Indian Act reform, Indigenous peoples addressed the growing socio-economic hardship for First Nations, Inuit and Métis communities despite the implementation of assimilative policies (see Turner 2006). Despite this hardship, Dale Turner (2006) convincingly argues that it was the "skyrocketing costs of running the Department of Indian Affairs" (16) that led the settler state to propose Indian Act reform.

Recommended reform of the Indian Act (1876) yielded another type of assimilationist legislation that became popularly known as The White Paper (see Turner 2006, 15). Relying on theories of "trickle-down" capitalism, White Paper legislation focused on integrating Indigenous peoples further into the mainstream Canadian economic and social milieu by eradicating Indigenous rights and status guaranteed by the Indian Act (1876). According to government officials, the price tag on Indigenous peoples' "special status" had incrementally increased and White Paper legislation "offered a practical way for the federal government to 'get out of the Indian business"” (Turner 2006, 16). If the Indian Act (1876) had been eliminated under the conditions proposed by the Trudeau government, Indigenous jurisdiction and inherent rights risk nullification. Therefore, the White Paper proposal initiated a large scale and consolidated response from Indigenous leadership that led to ongoing conflict between Indigenous peoples and the settler state. The White Paper represents a consolidation of neoliberal and settler projects that sought to 
engender assimilationist policies through minimal public investment that required an emphasis on the importance of "self-governing nations" (see Million 2013, 133-4). ${ }^{21}$

In this examination of how investment discourse and rationale is used by the settler state to destabilize Indigenous peoples' demands for jurisdiction, restitution and decolonization, my goal is not to simply characterize the discourse or practice of investment as 'good' or 'bad'; instead, I seek to problematize hegemonic assumptions that investment is a neutral economic practice that is necessary for contemporary governance and justice-making. Therefore, I follow Lemke by "question[ing] what appears to be well-ordered, rational responsible, self-evident, universal or natural in order to show the selective format of these practices and the power effects inscribed in them" (Lemke in Lindroth 2014, 344). Interrogating the notion of investment, I examine whether it is a necessary practice or whether it is a technique of governance that produces outcomes that primarily benefit the investor. I also explore assumptions that investment produces mutual beneficiaries and positive economic growth by examining whether there are "strings attached" to the settler state's commitment of public funds and national sentiment to Indigenous causes.

The language of investment has been used by scholars to describe the practice of racial supremacy and the imposition of settler authority. Lipsitz (2006) deploys the term investment to interrogate discriminatory practices used by financial institutions and American financial policy enacted against black people in the United States; while others have used the term to describe the political and economic purchase of whiteness in the Australian public sphere (see MoretonRobinson 2007). Scholars have also used financial terms such as "policy calculation" or "tradeoffs" (Holder 2014, 209) to explain how the Canadian settler state oversees Indigenous-settler negotiations. The deliberate use of investment vocabulary gestures to techniques and tactics that

\footnotetext{
${ }^{21}$ Numerous critical Indigenous Studies scholars have objected to the concept of self-government as imagined and implemented by the settler state (see Alfred and Corntassel 2005; Coulthard 2014).
} 
are employed by the settler state, but fails to describe a larger systematic approach to regulating and normalizing the coloniality of power in Canada. However, I wonder whether economic vocabulary can simply be used as a metaphor for the neoliberalization of Indigenous-settler relations? $^{22}$

To understand investment as both a practice and a rationale that shapes Indigenous-settler reconciliation, I turn to the Oxford English Dictionary where the term "investment" is defined in the following ways:

a) An outer covering or envelope;

b) Surrounding or hemming in of a military target, a blockade by a hostile force;

c) Investing money or capital-where income or profit is expected (n.pag.).

Unpacking the discourse of investment, I immediately note a contradiction between investment rationale and the principles of reconciliation. Within the definitions of investment are proclivities to "secure," "conceal" and "contain," while the central tenets of reconciliation emphasize the expansion of the historical record to reveal injustice. In observing the incongruity of these terms, I ask how and why investment discourse is routinely employed by the settler state in the context of reconciling Indigenous-settler relationships?

While the broadest definition of the term investment can be read as ambivalent, it is generally understood as a financial, political or emotional commitment that serves to produce a future surplus, whether it be in the form of capital or "good will." I employ the notion of surplus value to illuminate how and why investment logic is deployed by the settler state in the context of Indigenous-settler reconciliation. Diane Nelson's deploys Gayatri Spivak's concept of superadequation to describe how Indigenous peoples' subjectivity is readily defined its "ability to

\footnotetext{
22 Not unlike Tuck and Yang's (2014) important article, "Decolonization is Not a Metaphor," this doctoral project asserts that investment is not a metaphor but a set of principles and practices that is repeatedly enacted against Indigenous peoples by the settler state.
} 
produce a surplus that can be abstracted and extracted" (qted in Nelson 2015, 49). For this reason, David McNally (2006) asserts that surplus value "is the secret to the massive inequalities of capitalism: enormous amounts of wealth produced by workers accumulate in the hands of the owning class" (90). In using the concept of surplus value to describe how reconciliation functions within Indigenous-settler relationships, I mean to demonstrate two things: firstly, how the efforts and resources of Indigenous peoples are often used to reconcile relationships between Indigenous peoples and settler-Canadians, and secondly, how reconciliation is used to accumulate capital via economic development projects that privilege partnership and the pursuit of mutual (yet inequitable) economic beneficiaries.

The notion of surplus value is instructive for situating investment rationale because I assert that the investor benefits from an investment transaction far more than the investee benefits: that is because the investor is able to determine the parameters and outcomes of the transaction as well as the methods of repayment. For instance, in Canada, the work of reconciling often falls on the shoulders of Indigenous peoples or organizations that are chronically under-funded and where personnel are over-worked (see Castellano Vol. 1 2006), yet over time, the settler state has managed to consolidate control over reconciliation processes through legal procedures, policy reform (see Independent Assessment Process Secretariat 2012) and media narratives. For this reason, I suggest that the logic of investment should be problematized in relation to reconciliation because the perpetrator of historical injustice is positioned as a beneficiary of reconciliation processes. Investment discourse transforms reconciliation into an economic transaction wherein surplus power, money or affect can be reaped by the settler state. The "return" on an investment in reconciliation is determined through fiscal techniques (Neu and Therrien 2003) such as 
accounting and auditing and actuarial techniques (Samson 2012) that are deployed to assess and minimize risk during Indigenous-settler dialogue and negotiation.

The politics of accounting and auditing are central techniques to the deployment of investment rationale. The rise of a neoliberal economic system also coincides with a turn towards the "audit society," where organizations and bodies are routinely subjected to excessive scrutiny as a mechanism for exacting control (Power 1997; see also Strathern 2000). Repressive auditing and accounting techniques rose alongside "the rise of the "new public management," where "increased demands for accountability and transparency" were often initiated through neutral practices of cost/benefits schemas, public accounting and "quality assurance models" (Power 1997, 111). ${ }^{23}$ Any manner of public decision-making, including the enunciation of grievance are now frequently conceptualized through these frameworks. Accounting techniques are routinely deployed to protect elites as opposed to marginalized populations, and in turn, reify the supremacy of market relations (see Sargiacomo et al. 2013).

For example, the archive of Auditor General Reports documents the settler state's role in the exploitation of Indigenous peoples. In particular, Shelia Fraser's scathing report about policy practice in Indigenous communities was well-received by Indigenous organizations and leaders because it revealed the imposition of unfair auditing practices on Indigenous communities (see Auditor General 2011). Yet, the practices of auditing and accounting cut both ways in neoliberal Canada. As I will demonstrate in Chapter Six, Indigenous organizations and programs have been subjected to intense auditing that has bolstered prevailing assumptions about Indigenous

\footnotetext{
${ }^{23}$ The auditing literature presents interesting arguments about the tension between accountability and accounting. While organizations and government agencies should be required to document financial processes and procedures, auditing mechanisms are primarily viewed as an exercise in control and surveillance with the power generally resting with the state. Therefore, auditing literatures helps to engage with questions of transparency, in particular, who is rendered transparent through the process of auditing and whose actions are further concealed by auditing? (see also Strathern 2000; Shore and Wright 2000).
} 
organizations and communities, reflected in the popular settler imagination as bastions of corruption and thievery (see Henderson 2012). Therefore, the fiscal manifestations of investment logic are well-connected to the settler state's desire to minimize risk.

The history of the Canadian nation-state has been shaped by the confrontation of Indigeneity and coloniality in numerous ways, such as through constitutional talks, land claims negotiations, public commissions, and legal settlements. These negotiations have been designed to ensure the recognition of historical injustice and inequitable power relations between settlerCanadians and Indigenous peoples. However, during these negotiations, the interests of the state are always advanced and Indigenous peoples are routinely forced into compromise. The prevalence of lopsided negotiations have been frequently explored specifically in the context of the comprehensive claim process. Scholars like Mackey (2014) and Samson (2012) have observed that these negotiations almost always favour settler state interests despite the appearance that negotiations are designed to address Indigenous claims to rights, territory and jurisdiction.

Government interests are secured through the demand for extinguishment, which is tantamount to the nullification of Indigenous territorial and political rights (UBCIC, n.pag.), and the idea of certainty in land claims processes is primarily advantageous for the state. Certainty is used by the settler state to establish and define "the rights they acquire over land ceded to them" in land claims process, and to inform Indigenous peoples of the "extent and limitation of their land and other rights" (Samson and Cassell 2013, 38). Certainty guarantees that further contestation of land ownership is minimized through legally binding agreements. Despite land and capital transfer that are afforded to Indigenous peoples as part of settling claims, the "benefits" of these claims must be experienced by Indigenous peoples and communities alongside the surrender of other lands and rights. This is because governments and corporate actors conceive of Aboriginal rights 
"as the source of uncertainty" (Blackburn 2005, 594) that they desire to make certain in order to avoid lengthy consultation processes or protest. Instead, capitalist accumulation is depicted as logical and natural despite the reality that "capitalism is not synonymous with stability, rather it is an endless process of growth, contraction, creation, and destruction and it fuels the condition that Marx and Engels described as "everlasting uncertainty"” (Blackburn 2005, 594). To secure investment, the future must be rendered knowable (Sargiacomo et al. 2014, 577). In establishing certainty, there is an elimination of risk which makes certain territories available for investment and the expansion of profits (Shamir 2008, 6). A demand for "certainty" secures settler futurities through legal and political processes and negotiations, mostly notably in the context of land claims. In producing certainty in land claims, the authority of the nation-state is retained as the integrity of the nation-state remains intact (see Mackey 2014).

There is a direct correlation between investment logic and certainty, as means to demonstrate a lopsided economic relationship between Indigenous peoples and the settler state. This asymmetrical relationship defines Indigenous-settler relations and seeps into nearly all negotiations between these stakeholders. Any attempts that the settler state makes to generate a return from an investment in reparations sets up an economy of reconciliation that is based on exchange. David Graeber $(2011,114)$ critiques liberal democratic assumptions that "imagine" justice as a form of "reciprocity" because these reciprocal relationships are often steeped in hierarchical power relations, where the elite actor is almost always the beneficiary. Anti-colonial and critical Canadianist scholars have instead insisted that ensuring just negotiations requires the settler state to deal with uncertainty (Mackey 2014), or disappointment (Bell 2008), when settling land claims or in the implementation of Indigenous peoples' rights and jurisdiction. Therefore I 
assert that Indigenous peoples should be able to determine the outcomes of negotiations designed to ensure realization of just restitution.

Nonetheless, the settler state continues to create processes and procedures that reflect mainstream political, legal and economic values. The redress and reparations process is no exception. Paulette Regan (2010) describes the redress process as a form of "re-gifting," where government promises of providing a "neutral form of justice to Indians in order to heal and save them" actually "created new legalistic, bureaucratic solutions...that simply replicated colonial power relations in a new form of violence" (142). ${ }^{24}$ This problematic approach to negotiating Indigenous peoples' grievances leads to further violations committed against Indigenous peoples through the very process that has been designed to address the historical injustice that they experienced in the first place. To challenge the re-gifting approach, I turn to Rauna Kuokkanen (2006), whose examination of the gift economy might be useful in conceptualizing the renewal of Indigenous-settler relationships by providing an alternative to capitalist and exploitative forms of exchange. The gift economy has historically been theorized by anthropologists as an "Indigenous" system of exchange where gifts are given to ensure social and political power in return (see Mauss 1954; Bordieu 1977). However, Kuokkanen (2006) has instead suggests that the gift economy is based on relationships that are built on respect and responsibility to all peoples and the land:

The gift is a reflection of a particular worldview characterized by a perception of the natural environment as a living entity which gives its gifts and abundance to people if treated with respect and gratitude (i.e. certain responsibilities are observed). Central to this perception is that the world is constituted of an infinite web of relationships, extended to and incorporated into the social condition. (258)

\footnotetext{
${ }^{24}$ In his exploration of accounting techniques and settler governmentality, Dean Neu (2000 b) identifies a system of exchange between Indigenous peoples and settler authorities where land was purchased by the latter but payments for said land were routinely described as "presents".
} 
This conceptualization of relationships supersedes market relations and the politics of exchange by envisioning a specific form of relational reciprocity (Kuokkanen 2006, 258). Therefore, any mode of exchange between Indigenous peoples needs to be based on a form of reciprocity that is always preceded by responsibility and accountability.

My interrogation of investment contributes to the scholarly field of settler colonial studies. In this project, my outline of how investment rationale has been used historically to shape Indigenous-settler relations and negotiations looks specifically at how investment is applied to the reparations process during the ascendancy of neoliberalism in Canada. I argue that the investment rationale conceives of reconciliatory expenditures within a paradigm of exchange, where Indigenous subjects are offered opportunities for "healing" (see Million 2013) but are then compelled to "partner" with the nation-state to secure the possibility of capitalist accumulation for the ongoing benefit of the reproduction of the settler state.

\section{Affecting Investment}

This section foregrounds the importance of settler and neoliberal affect in bolstering investment rationale. I draw on groundbreaking scholarship that situates settler affect (Mackey 2014; Million 2013; Rifkin 2011; 2013) and neoliberal affect (Berlant 2011; Duggan 2003; Ventura 2012) as factors that influence and exacerbate structural oppressions such as racism, sexism, homophobia and class hierarchy. Affect can function to support dominant systems of violence, oppression and restraint but is also deployed to critique the depersonalization of institutional processes and the depoliticization of social problems (see Cvetkovich 2003). Scholarly literatures on reparations, reconciliation and apology all feature an analysis of exchange (Mackey 2013; James 2008) that are instructive in understanding the machinations of the settler state and the prevalence of investment rationale. Nonetheless, I am hesitant to characterize political 
emotions and feelings as an emotional investment for fear that my exploration of public feelings will reproduce investment rationale.

Building on Claire Moon, my doctoral project notes that the material (bodies, organizations, and mode of exchange) cannot be decoupled from the affective. The influence of liberal, neoliberal and settler affect is visible in the reproduction of ideologies that are reified to such a degree that they are accepted as a morality or a commonsense (see Rifkin 2013). For instance, Sherene Razack “make a very important observation when she argues that 'imperialism' is not just about accumulation but about the idea of empire...Empire is a structure of feeling, a deeply held belief in the need to and the right to dominate others for their own good, others who are expected to be grateful" (qted in Gordon 2010, 47). Settler affect, which consists of commonsense assumptions shared by the mainstream citizenry, are routinely circulated by the settler state to reinforce the legitimacy of white, Eurocentric power in settler societies. For instance, Mark Rifkin (2011) notes that "[p]rocesses and institutionalized frameworks of settlement - the exertion of control by non-Natives over Native people and lands - give rise to certain modes of feelings, and reciprocally, particular affective formations among non-Natives normalize settler presence, privilege and power" (342). As settlement is rendered unassailable by the circulation of affect, it is reinforced by myths of benevolence such as the peacemaker myth that "lies at the heart of the settler problem; it informs, however, unconsciously, the everyday attitudes and actions of contemporary politicians, policy makers, lawyers, and negotiators, and it remains an archetype of settler benevolence, fairness, and innocence in the Canadian public mind" (Regan 2010, 87). Therefore, settler affect bolsters assumption of settler legitimacy and benevolence but has also been used to insist that Indigenous peoples are privileged because of the supposed "special rights" afforded to them through the Indian Act (1876) (see Coulthard 2014). 
Similarly, neoliberalism is reinforced by structures of feeling that legitimize its exploitative constructs. Not unlike the power of settler affect, neoliberal affect is rendered fundamentally powerful because the "structure [of the economic system] rests largely below the consciousness of most non-academics and non-progressive activists" (Ventura 2012, 3). This means that neoliberal economic doctrine is circulated as a form of a commonsense knowledge or feeling that has an unknown point of origin (see Henderson 2013, 69). Therefore, neoliberalism is permitted to function as "as a kind of nonpolitics - as a way of being reasonable, and of promoting universally desirable forms of economic expansion and democratic government around the globe" (Duggan 2004, 10). Neoliberal feelings are spread to normalize oppressive systems, which remain unquestioned, and resistance to dominant ideals is fundamentally limited. Neoliberalism as a structure of feeling is primarily beneficial to the nation-state because citizens "feel" responsible for their own health and prosperity, and therefore, feel individual shame for relying on the state resources while also deploying anger towards fellow citizens who need to access social programs.

Since the realization of a reconciled Canada and other settler states would, at least in part, be based on fundamental attitudinal change, observing the role of feeling and emotion is of utmost importance when analyzing reconciliation. I am interested in looking at how emotions and feelings get folded into economic processes for the purposes of legitimacy and achieving return for dominant actors. At the same time, I observe that emotion and feeling is difficult to control and contain, and may provide significant possibilities for resistance.

\section{Methodology}

The Indian Residential Schools Settlement Agreement represents "an object of study that cannot be accounted for ethnographically by remaining focussed on a single-site intensive investigation" (Marcus 1995, 96). Instead, the IRSSA's manifold restorative components require a multi-site methodology in order to trace how reconciliation is enacted in different ways and in 
different contexts. Since discourses of Indigenous-settler reconciliation are constructed "in multiple sites, as well as through representations, institutions, and policies" (Mackey 1999, 6), ${ }^{25} \mathrm{I}$ theorize the complex interplay between nationalist mythologies, policy convergence and economic processes as a way to map the confluence of intricate legal processes and institutional mandates. Multi-site methodologies are essential in order to "follow people, connections, associations, and relationships across space" (Falzon 2009, 1-2), and this can be accomplished "conceptually by means of techniques of juxtaposition of data" (Falzon 2009, 2). This project draws from multiple data sources, such as newspaper articles, public speeches, government and organizational documents. Documents demonstrate official positions explicitly deployed by the settler state, and can be used to consolidate the dominant discourses that have been historically - and currently are - in circulation. At the same time, I link my case studies to policy frameworks utilized by the Harper government, as well as the influence of neoliberalism in the public sphere.

Part of the necessity for studying the Indian Residential School Settlement Agreement via multiple sites is that, while the agreement is crystallized in language and approach through legal discourse, its implementation yields unsettling aspects that could not have been anticipated. The IRSSA is rendered unstable given that structural obstacles to equitable Indigenous-settler relations have prevailed throughout the last 30 years, despite the intentions of the government or party in power. Nonetheless, the Harper Government demonstrated starkly different politics than the Liberal government under Paul Martin, who helped to formulate and implement the agreement. Therefore, a nuanced account of these political and ideological differences is required.

I have structured the argument of this doctoral project by comparing Indigenous peoples' claims to justice and the settler state's responses to these claims. To assess this comparison, I

\footnotetext{
${ }^{25}$ For further examples and/or theorizations of multi-site ethnography, please see Falzon 2009; Nadar 1990; Martin 1994; Marcus 1995; Tsing 2005.
} 
examined key texts associated with the Indian Residential Schools Settlement Agreement in particular and Indigenous-settler relations more generally. In documenting these contrasting positions, I am creating an archive that can be used to reveal the subtle and nuanced ways that settler interests and neoliberal ideas are privileged by settler institutions in response to Indigenous claims to justice.

My findings incorporate nine interviews conducted with members of "reconciliation organizations"- a pool of "stakeholders" spanning government departments, legal counsel and the voluntary sectors. ${ }^{26}$ These interviews were conducted over the course of 2011 through a set of 10 open-ended questions. Each I interview averaged 52 minutes in length. They were primarily exploratory and, therefore, utilized to gather information on processes and practices that were difficult to investigate through secondary sources since the players and dimensions of the IRSSA are generally shrouded in secrecy. I used the content of the interviews to understand how closely affiliated certain actors are with IRSSA processes, the complexity of the agreement's governance, and the structural capacities and limitations of the agreement. ${ }^{27}$

My argument is also informed by observations I garnered upon attending five national events hosted by the Truth and Reconciliation Commission of Canada. ${ }^{28}$ While at these events, I had the opportunity to experience the various speeches and testimonies that comprise TRC proceedings first-hand. Online capabilities allowed me to also observe the programming at

\footnotetext{
${ }^{26} \mathrm{I}$ received ethics clearance from Carleton University in October 2010.

27 I have chosen not to include the interview transcripts here because I am committed to keeping interviewees anonymous and since the "reconciliation community" is relatively small, I fear that by revealing the actual transcripts, my interviewees may be identified. When interviewing stakeholders, I was able to share information that I had collected in other parts of my research process with them, which proved to be valuable to some of my interviewees.

${ }^{28}$ I attended five National events hosted by the Truth and Reconciliation Commission: Winnipeg, Manitoba (June 2010); Inuvik, Northwest Territories (June 2011); Halifax, Nova Scotia (October 2011), and Montreal, Quebec (April 2013) and Ottawa, Ontario (June 2015).
} 
TRC events that I was unable to attend in person. ${ }^{29}$ The National Events hosted by the Truth and Reconciliation Commission were large affairs that included and depended upon the participation of settler-Canadians. I attended these events for several reasons: to not only participate in the process of witnessing and testimony, but to experience the stories told as more than just a text or performance. Attending events afforded me the opportunity to witness firsthand the emotions generated by public reconciliation in all its political and creative forms. This dissertation draws on transcripts produced during these events, which I received from contacts who formerly or currently work for the Truth and Reconciliation Commission. These transcripts are cross-referenced with my own recordings and the recordings of events made available by the Truth and Reconciliation Commission of Canada.

I consider former students to be the primary "stakeholders" in the agreement, and I acknowledge the active, consultative role in negotiating the agreement and its components. However, the Canadian legal system imposes numerous constraints on the possibilities for reconciliation through the rigidity of "class" and "eligibility" criteria that are built into the agreement. These constraints on reconciliation processes are further compounded by epistemological assumptions utilized by legal practitioners, whose job it is to directly negotiate the parameters of law and justice. Consequently, as a scholar I strive to portray this agreement as a porous entity that is both susceptible to co-optation but also functions as a site of resistance. My dissertation is therefore guided by important methodological questions such as: how do I maintain a structural critique of Canada's Indian Residential School Settlement Agreement without undermining Indigenous peoples' participation and contribution to the agreement?

\footnotetext{
${ }^{29}$ The expense of travel to these locations soon became prohibitive. I was unable to attend the Saskatoon event due to lack of funding, however, I was able to participate online through webcasts. I did not travel to events after the Montreal event because I needed to cut off my research at some point, therefore I did not attend the events in Vancouver (September 2013) and in Edmonton (March 2014).
} 


\section{Summary of Thesis}

This dissertation documents an ongoing confrontation between Indigenous peoples' demands for redress and restitution through discourses of decolonization, while settler governments routinely present reconciliation as an investment for both settler Canadians and Indigenous peoples. In the following chapters, I examine this discursive confrontation as well as the political and socio-economic ramifications of applying investment rationale to Indigenoussettler reconciliation. In doing so, I examine the underlying influence of neoliberalism on settler law while underscoring of the role of emotion and affect in constituting investment rationale.

Chapter Two documents the convergence of three ideological projects, settler colonialism, neoliberalism and reconciliation, in order to trace the ascendancy of investment discourse in Indigenous-settler relations. I suggest that these three projects work together to ensure the continuity and supremacy of coloniality in Indigenous-settler negotiations by ensuring that Indigenous jurisdiction and self-determination are bypassed. I document how investment rationale is operationalized in three different historical periods - the Constitutional Talks, the Royal Commission of Aboriginal Peoples and during the Indian Residential Schools Settlement Agreement— by tracing three different forms of investment that coincide with these three distinct eras: national, social, and therapeutic.

Chapter Three examines the politics of investment in the context of the Indian Residential Schools Settlement Agreement. Reparations are designed to be accountable to Indigenous peoples by publicly addressing historical injustice and ensuring the process to access compensations is just and equitable to victims of harm. Nonetheless, through both state-sponsored and court-ordered reparations processes, there is a tension between the settler state's accountability to victims of historical injustice and the Canadian taxpayer. I argue that this tension legitimizes the application of investment rationale to reparations provision. By documenting the politics of legal processes 
such as alternative dispute resolution, class action settlements and restorative justice, I argue that investment rationale engenders strategies of containment to curtail spending and the optics of culpability and where monies are actually paid, reparations are designed to reap a benefit for all parties, even the settler state which for all intents and purposes is identified as the perpetrator.

Building on the assertion that accounting processes are used to manage Indigenous subjects who are applying for compensation and redress, I argue in Chapter Four that investment rationale is strengthened when a therapeutic ethos is applied to legal processes. This chapter examines the application forms utilized by the Independent Assessment Process, and more specifically, looks at how the medicalization of abuse and trauma in the compensation process constructs Indigenous legal subjects as "unhealthy" and unable to "work" through the compensation process. The medicalization of trauma individualizes the experience of mental health and, therefore, reinforces racialized perceptions of dysfunction in Indigenous communities, as compared to settler communities which are figured as spaces of wellness. Taking these claims into account, this chapter illustrates that compensation payments function as therapeutic investment because they bolster the belief that economic development and economic contribution are the key to health and emancipation for Indigenous peoples.

Chapter Five looks at health support provision to former residential school students in order to examine how Indigenous organizations are routinely disciplined through government scrutiny and regulation. I demonstrate how the settler state enacted a premature disinvestment in Indigenous health supports during the Indigenous-settler reconciliation process. To substantiate this claim, I examine how the politics of "audit culture" are overwhelmingly directed at the Aboriginal Healing Foundation despite the organization's exceptional compliance to government regulations. Despite the excessive regulation of the Aboriginal Healing Foundation, the Indian Residential Schools 
Resolution Health Support Program housed in Health Canada has never received an official evaluation. For this reason, I link the Aboriginal Healing Foundation's closure to its radical approach to community programming that threatened to unsettle settler state authority over health programming.

In Chapter Six, my analysis shifts to examine the "Expressions of Reconciliation" programming at the Truth and Reconciliation Commission of Canada. Analyzing transcripts from the Truth and Reconciliation Commission National Events, I demonstrate how Indigenous-settler "partnership" function as a therapeutic investment because this mythologized ideal has been deployed to secure more profitable social relations, specifically for public institutions and corporate entities. To do so, I examine how "Expressions of Reconciliation" emphasize settler participation to foster successful cross-cultural "bridge-building" and are always framed with the goal of enhancing the economic prosperity of the nation-state. As counter to the deployment of partnership, I examine the creation of strategic partnerships as a radical expression of affection and defiance that leads to community activism and co-operation.

In my Conclusions section, I outline how Indigenous peoples have been promised redress to reconcile a social debt owed to them by the settler state for a history of injustices, ranging from child removal, the denial of self-determination and dispossession. Yet, in the process of reconciliation, the provision of reparations are tied to assumptions and expectations of Indigenous peoples' well-being and economic contribution. These ties bind Indigenous peoples to the settler state in a potentially problematic way that positions them as neoliberal subjects indebted to the state. 


\section{Chapter 2: The Economics of Reconciliation: Investing in Indigenous-Settler Relationships}

I think what has been positive in the last day and a half is that we have been trying to find, I think, that most useful precept in politics, we have been trying to be just in our time and there has been the usual historical references and damnations of the devil and of colonialism and of other forms of diabolical actions, but you know I don't feel guilty for the past. Don't ask me to be repairing what was done wrong in the past...[W]e are all starting our lives today and as leaders of government or of groups, our task in these two days is to be just in our time and not to try to pay for what now appears to be errors of others, but what has been done in the best faith, I am sure, by the people who conceived and wrote the Indian Act one hundred years ago with the mentality that prevailed at the time (Former Prime Minister, Pierre Eliot Trudeau. 1983 First Ministers Meeting on Aboriginal Constitutional Matters, 261).

Good relationships are also smart business. With this in mind, the costs that I want to explore with you today are the opportunity costs of doing nothing - the missed chances, forgone gains - a future less than it might otherwise be (Coffey 1997, n. pag.).

Our imaginings of peace and reconciliation must also confront the dark, specifically economic side of war if we are to put the practice of violence out of business (Laura Nadar 2003, 197).

The Crown-First Nations Gathering held on January 24, 2012 was organized by the

Canadian government and the Assembly of First Nations (AFN) to establish a dialogue between

First Nations leaders and federal representatives to address historic acrimony between Indigenous

peoples and settler-Canadians. The Assembly of First Nations publicly stated that the event would "directly build" upon official reconciliatory initiatives such as the Truth and Reconciliation Commission of Canada (Assembly of First Nations 2012 a, n. pag.). Reconciling injury and "settling" historical inequality between Indigenous peoples and the Canadian state was cited as a key goal of the Gathering for both AFN and government representatives. However, the language used by government representatives reveals a conflation of investment rationale and reconciliation that may impede the realization of social justice for Indigenous peoples.

Former Prime Minister Harper described the history of Indigenous-settler relations at the

Gathering by stating:

[T]he relationship between our peoples was tainted, tainted in a manner that eroded trust and blocked ways forward as does a tree fallen across a road, tainted in particular by the experience of the forced residential schools, the explicit attempt to destroy aboriginal [sic] culture and to dismantle the aboriginal family that wounded so many so deeply. That is why one of my most rewarding days in office was when I rose in the 
House to deliver an apology to those students. We acknowledged that sad chapter in our history. We repudiated the thinking that lay behind it, and, we went beyond symbolism; we took concrete action to settle the claims of those who had been injured. (Assembly of First Nations 2012 b, emphasis mine) ${ }^{30}$

To demonstrate a commitment to alleviating any injury caused by this "tainted relationship," former Prime Minister Harper promised "concrete action" such as implementation of clean water systems in Indigenous communities and the speedy implementation of land claims. Despite the benefits that may underlie the commitments to Indigenous well-being outlined by the former Prime Minister, he characterizes

[t]hese things we have done, Ladies and Gentlemen, as a down payment on what we wish to achieve. For our goal is self-sufficient citizens and self-governing communities. Our goal is to promote improved governance. Our goal is much increased aboriginal participation in the economy and in the country's prosperity. (Assembly of First Nations 2012 b, n.pag.)

These statements demonstrate how injury and grievance are transformed into an economic transaction tantamount to the practice of investment. By equating public investment with the concept of "down payment," capitalist logic is applied to the commitment of public funds whereby the nation-state seeks a financial return on monies devoted to "Aboriginal policy." Investment, in this context, functions as a discourse that expressly advances a cost/benefit framework to ensure the creation of mutual beneficiaries from Indigenous peoples' experience of social disparity. This is accomplished by describing public investment as a down payment for the accomplishment of future goals. In the following chapter, I identify three different eras relative to Indigenous-settler negotiations to explore how the politics of investment can both represent a commitment to redistributive economics and signify a consolidation of settler and neoliberal projects. In this

\footnotetext{
${ }^{30}$ The concrete action referred to in this quote is attributed to policy initiatives such as "accelerating specific and comprehensive claims," "secur[ing] water-system accountability" and "rout[ing] more than a billion dollars of Economic Action Plan funding to investments for Aboriginal and northern communities" (Assembly of First Nations 2012 b, n. pag.).
} 
chapter I show how Indigenous peoples' goals of redress are routinely framed through capitalist market relations. The question then becomes: what are the ramifications of using investment rationale to frame the reconciliation of Indigenous peoples and settler Canada?

I analyze public documents, speeches and policies that "represent key sites [sic] of hegemonic struggle over the principles and values" (Benjamin 2007, xxviii) of Indigenous-settler reconciliation. The history presented here is partial and selective because I only examine instances where Indigenous representatives and the settler state enter into official dialogue. It is notable in this analysis that Indigenous peoples and organizations often use the language of investment to appeal to settler elites in advocating for social justice and redress. Indigenous groups may frame their demands strategically in this way because "[h]ow groups frame their demands and the discourses they use is as important a factor in whether they get heard and whether they have political voice and visibility" (Williams 2012, 105). This is important to note when analyzing Indigenous discourses of investment because "how these claims are then reinterpreted by state institutions through the frames they use will shape whether and how the claims are implemented, and their outcomes" (Williams 2012, 105). Stated more clearly, using investment discourses may leave Indigenous peoples' proposed outcomes vulnerable to co-optation by the values of mainstream Canadian society, while at the same time, using this frame is paradoxically the only way for these claims to be "heard." My discussion of the three stages of reconciliation demonstrates that the discursive terrain used to articulate Indigenous peoples' quests for redress over time begin to dovetail with state discourses of "sovereignty," "costs and benefits," and “economic development." When this occurs, the potential for Indigenous peoples' claims to become mired in neoliberal and settler logics is sharply increased, such as the dilution of redress claims. 
In the following chapter, I examine how Indigenous peoples routinely advocate for holistic social investments and a suitable land base for economic development by using the language of autonomy and jurisdiction. I show how settler governments re-frame these requests for investment as opportunities for economic investment and as a pathway to the accumulation of capital. To map the historical shifts in the concept of Indigenous-settler reconciliation, this chapter demarcates and examines three different "eras of reconciliation," namely: Section 37 Constitutional Talks, the Royal Commission on Aboriginal Peoples, and Reparations for former students of the residential school system. These three eras of reconciliation roughly coincide with three forms of investment: a) National; b) Social; and c) Therapeutic.

\section{Depending on Canada: National Investment}

In 1982, the Canadian Constitution was amended to reflect the affirmation of Indigenous rights. The inclusion of Section 35 into the constitution stated that: "The existing aboriginal and treaty rights of the aboriginal people in Canada are hereby recognized and affirmed." While the recognition of inherent rights was welcomed by Indigenous peoples, these rights remained undefined, difficult to apply in real-life contexts and vulnerable to political interpretation by the settler state. In response to these concerns, Section 37 of the Constitution Act, 1982 stipulated that four First Ministers meetings were required to construct a framework to delimit the rights guaranteed to Indigenous peoples in the repatriated Constitution. From 1983-1987, Canada, the provinces, and major Indigenous organizations (namely, the Assembly of First Nations, the Inuit Council of Canada, Métis Council of Canada and the Native Council of Canada) met on four separate occasions. ${ }^{31}$ These meetings, chaired by two different Prime Ministers, ended without

\footnotetext{
${ }^{31}$ The transcripts of these meetings reflect that participants were determined to define constitutional rights in a political forum, since legal remedies were deemed ill-suited, costly and impractical, and reflected concerns of a burgeoning neoliberal program in Canada. As Indigenous Peoples of Canada had fared well in legal battles, the compartmentalization of political and legal strategies could be viewed as an act of tactical importance for state
} 
agreement or consensus amongst participants primarily because the issues of Indigenous selfdetermination and self-governance were particularly divisive. This section examines how Indigenous delegates claimed that an extension of political and economic jurisdiction was necessary to enact constitutional reconciliation, whereas government leaders advocated for "reconciling relationships" to counteract the supposed socio-economic marginalization of Indigenous peoples from the nation-state.

The affirmation of existing Indigenous rights in Section 35 in the Constitution Act, 1982 was of particular importance to historical and contemporary debates about the meaning of reconciliation. Kiera Ladner (2006) advocates for

an understanding of the Canadian constitution that speaks of political reconciliation and thus, the formal reconciliation of Indigenous and Canadian constitutional orders in a manner that does not avoid the 'big issues' of sovereignty, subordination and negotiated inferiority, colonial legacies, decolonization, and the continued existence of Indigenous governments (as governments). (n. pag.)

Ladner's definition moves beyond limited understandings of reconciliation that represent a pathway to the cultural recognition of "indigenous difference" (Maaka and Fleras 2005, 294), and instead "acknowledges that Indigenous peoples embrace a unique constitutional status with a special relationship to the Crown" (Maaka and Fleras 2005, 294). The acknowledgement of Indigenous peoples' unique constitutional status constitutes the public affirmation of specific Indigenous histories, epistemologies, and forms of governance. ${ }^{32}$ Brian Bird (2010) notes that in

authorities. Since reconciliation deployed in a legal context could help demarcate and enforce the parameters of political and jurisdictional sovereignty, a political interpretation of the concept was favoured by state participants so as to emphasize a rights-based approach to reconciling Canada. The compartmentalization of legal and political approaches to reconciling is important to note, since legal strategies were relied upon greatly in reparations programs following the conclusion of the Section 37 meetings (See First Ministers 1983; 1984; 1985; 1987).

32 Sa'ke'j Henderson (2013) has also asserted that "the concept of constitutional reconciliation-literally, the reconciling of Canadian law with Aboriginal and treaty rights entrenched within it-is an integral starting point for the overarching political, social, cultural, and economic process of reconciliation between Aboriginal peoples and the Canadian state" (115). 
legal cases after the R. vs Sparrow decision (1990), the concept of reconciliation was used to define Indigenous-state relationships, both politically and territorially. He cites the Mikisew Cree First Nation v. Canada (2005) decision, which stated that "the fundamental objective of the modern law of aboriginal and treaty rights is the reconciliation of aboriginal peoples and non-aboriginal peoples and their respective claims, interests and ambitions" (Bird 2010, n.pag.). Eva Mackey (2013) notes that this "form of reconciliation assumes that the legal sovereignty of the state always supercedes Aboriginal rights, and implies that Indigenous people might reconcile themselves to inferiority" (52; see also Alfred and Corntassel 2005; Coulthard 2008; Gordon 2010). ${ }^{33}$ Mackey (2013) cautions that the supremacy of Canadian law exists has presented ongoing obstacles to Indigenous self-determination even after the repatriation of Constitution.

At the 1983 First Ministers Meeting on Aboriginal Constitutional Affairs that took place in Ottawa, the Native Council of Canada defined self-determination as "the right to make decisions about ourselves, to enforce through our own institutions our cultures and our languages and our tradition so that they don't disappear within the Canadian milieu"(1983 First Ministers, 129). This definition of self-determination rejects the discourse of multiculturalism that was popularized in the 1970s where Indigenous peoples were subsumed under a mosaic of "minority" cultures. Being subsumed under the multicultural model destabilizes the unique Constitutional status of Indigenous peoples and reinforces Canadian sovereignty. During the First Ministers' Meetings, federal and provincial delegates questioned Indigenous self-determination and routinely asserted the sole legitimacy of settler state sovereignty. For instance, long-serving New Brunswick premiere Richard Hatfield argued that "if the argument is that we are here to acquiesce to the claim

\footnotetext{
33 While the constitutional definition of reconciliation demonstrates some promise in extending rights, as I will demonstrate throughout this chapter, there is the potential that this concept may confine Indigenous peoples to a minoritized position within the nation-state of Canada upon whom rights are bestowed by the settler state (see Diabo 2012).
} 
of the aboriginal people that this land is theirs, and therefore, they should be left to do and legislate as they see fit, then it doesn't make any difference what my position is, because I don't have any position. I am not a citizen of this country or this piece of geography because I was late in being put here by the Creator" (First Ministers 1984, 152). ${ }^{34}$ Hatfield's assertion (however dramatic) reveals a common belief amongst government delegates that self-determination was an affront to Canadian sovereignty and citizens. Instead of seriously considering the potential for Indigenous self-determination, Government delegates shifted the discourse to advocate for measures to "include" Indigenous peoples into Canadian society.

Narratives of exclusion were frequently circulated during the Section 37 talks, particularly in the context of economic development, corporate investment, and the safeguarding of the nationstate's prosperity. In 1983, premier Grant Devine stated that "[i]n Saskatchewan we are taking positive and imaginative steps to foster economic development for all citizens, aboriginal and nonaboriginal alike. Everyone can and will share in our growth" (First Ministers 1983, 76). The need to "save" Indigenous peoples from poverty and dysfunction is presented as a win-win strategy for both Indigenous peoples and the settler state. In 1985, Brian Mulroney noted that "[t]he decision that we make together, if we can come together on this, will mean self-reliance rather than dependence. It will mean Aboriginal pride and a sense of self-worth. I believe that if governments in Canada are willing to take this step in recognizing the right to self-government in the Constitution, it will do much to nurture the creative energies of Aboriginal peoples and to ensure

\footnotetext{
${ }^{34}$ The realization of self-determination has historically been misunderstood as an act of political and territorial secession from the Canadian nation-state. Joyce Green (2001) clarifies that self-determination is not about secession but implies "a right implying the capacity for statehood, though not requiring state form," and once enacted "can be expressed as sovereignty within existing states, as a form of federal association or (although few indigenous peoples prefer such a diluted formula) as a form of local administration within states" (733). The language of secession presented by state authorities as tantamount to the demise of the Canadian nation-state is used to undercut Indigenous access to resources and territory that have benefited settler Canadians for generations.
} 
ultimately their full and generous participation in Canadian society" (First Ministers 1985, 101). According to Mulroney, the benefits of inclusion in mainstream Canadian society are both material and affective, as Indigenous peoples would enjoy both economic growth and the growth of their "self-worth."

The exchange of dependence for self-reliance used by Mulroney in the passage above indicates the re-articulation of self-government as a means "to incorporate Aboriginal communities into capitalist relations of production and deny other socioeconomic visions" (Green 2003, 52). Indigenous delegations have suggested that economic dependency has historically been instituted by the settler state to ensure unfettered access to Indigenous lands and resources in order to strengthen the settler state economy and to "create" opportunities for corporate investment. ${ }^{35}$ In short, assumptions that economic marginalization and dependency are the "choice" of Indigenous peoples functions as a convenient narrative mobilized by federal and provincial delegates to support paternalistic settler attitudes that present Indigenous peoples as incapable of development due to their exclusion from mainstream Canada. To counter these assumptions, Indigenous delegates routinely asserted their right to jurisdiction over territory as the central concern of defining constitutional reconciliation (see First Ministers 1983; 1984; 1985; see also Diabo 2012).

The extension of jurisdiction to Indigenous peoples was seen as an important component in combatting the economic exploitation of Indigenous territories, which was cited by Indigenous delegates as the primary cause of economic dependency. At the 1985 First Ministers' meetings, the Native Council of Canada (NCC) delegation stated that:

Indian self-government to us is not having multinational corporations border on our reserves and destroy the resources which we live on. Indian self-government is having a fair share of those resources so that we can have a government that is independent rather than having the present situation, which is not Indian self-government, where we have a

\footnotetext{
${ }^{35}$ See also Canadian political economy scholars who address the inequitable economic relationships between Indigenous peoples and settler-Canadians (Gordon 2010; Wotherspoon and Satzewich 2000).
} 
welfare state in that majority of our communities. That is not Indian self-government. (First Ministers 1985, 103)

In this quote, the NCC suggests that the perpetual denial of jurisdiction and inequitable access to resources has maintained Indigenous peoples' economic exploitation by the Canadian state, resulting in continued economic dependency. A similar position had been mobilized by the Assembly of First Nations delegation in 1984 when they stated:

Where our economies have not been destroyed by loss of resources, we support our families. We put food on our tables. We live in dignity. We do not want dependency. We do not oppose development but we want development that respects our cultures and our traditions, that respects the land, that makes us partners in the Canadian economy. (First Ministers' 1984, 19)

Indigenous delegates demonstrate their frustration at being frequently cast as "dependent" on Canada, which is also meant to be indicative of Indigenous peoples' inequality and separation from the rest of Canada. Yet, Mark Rifkin $(2011,350)$ notes that this type of settler authority is maintained through affective tactics that re-articulate Indigenous peoples' grievance as an experience of exclusion from national belonging. In framing Indigenous-settler relationships through the lens of inclusion, "racist exclusion from citizenship" becomes the main cause of injustice for Indigenous peoples as opposed to their "forced incorporation into the state" (Rifkin 2011, 342). The forced incorporation of Indigenous peoples into the nation-state and the exploitation of Indigenous territories were routinely discussed by Indigenous delegates and dismissed by government delegates.

From the outset of the Constitutional Talks, the Assembly of First Nations delegation ${ }^{36}$ addressed misconceptions about economic dependency and development by suggesting that settler

\footnotetext{
${ }^{36}$ There were several members of the Assembly of First Nations in the delegation, and in 1983, the main speaking representatives were National Chief David Ahenakew and Regional Chief George Erasmus. By 1985, George Erasmus became the National Chief of the Assembly of First Nations and the primary representative for the organization. In 2002, David Ahenakew uttered anti-Semitic remarks at a meeting he was attending and was eventually tried for hate
} 
prosperity had been achieved at the expense of Indigenous self-governance and jurisdiction. The Assembly of First Nations delegation stated: "[W]e [First Nations] have more invested in the Canadian Federation than anyone else, because without Indian lands and resources, the Federation would have no economic base and no gross national product and no national economy and there would be nothing over which the other two governments, federal and provincial, would have jurisdictional debates to conduct" (First Ministers 1983, 15). Investment, as deployed by the Assembly of First Nations, is related to the affirmation of jurisdiction where the goals of economic development are free of government control and coercion. Anishinabe/Ojibway scholar John Borrows aptly notes that Indigenous peoples

are not, by and large against economic and social expansion in the broader nation-state. In fact, these aspirations can even be complementary with it. They demonstrate that Aboriginal peoples wish to shape more direct benefits of development. Aboriginal peoples also show a desire to have greater control over how development is undertaken to ensure that the development conforms to their values and objectives (Borrows 2001, 620).

Borrows outlines what is at stake in the politics of economic development and investment by questioning who the beneficiaries of development are, and under whose authority these projects are executed. Therefore, in asserting the right to economic development alongside an extension of jurisdiction, Indigenous delegates viewed the just negotiation of constitutional reconciliation as potentially holding the key to economic reforms that were redistributive in nature. Government officials, however, did not view an investment in economic development as akin to a reallocation of resources, but as an opportunity to create "mutual economic beneficiaries."

The emphasis on mutual beneficiaries shifted the conversation in First Ministers' Meetings from self-determination to the disruption of the relationships between settler Canadians and Indigenous peoples, leading to a conflation of investment and reconciliation discourses. When

crimes. The comments I cite in this chapter are representative of the delegation's position and are not a reflection of his personal views. 
introducing the term reconciliation into common parlance, former Prime Minister Brian Mulroney stated:

My objective at the Regina Conference on the Economy, and again at the National Economic Conference, was to encourage the key actors in the Canadian economy to recast their dialogue in terms that made issues into shared concerns, not jurisdictional disputes. And so no one should be surprised that one of my objectives for this Conference is to encourage all participants to accept their share of responsibility in the search for new understandings. You know of my commitment to national reconciliation. You know of my determination to breathe new life into and restore harmony to federal-provincial relations. We have seen the advantages of moving to consensus and the new hope it offers us. (First Ministers 1985, 3, emphasis mine)

I suggest that Mulroney's deployment of "shared interests" constitutes what Dene scholar Glen Coulthard calls mutuality. Coulthard warns that narratives of "shared interests" or mutuality gloss over this history of state violence, inequality and discrimination $(2008,188)$ by implementing strategies or proposals that privilege relationship-building. This type of strategy was deployed by government officials, and Inuit leader John Amagoalik responded by stating that "[i]t would be fair to say that a spirit of reconciliation prevailed over the numerous officials and ministerial meetings we attended. Non-beneficial rhetoric fell by the wayside as participants moved on to the business of discussion actual Constitutional amendments" (First Ministers 1987, 25). I argue that Amagoalik's quote implies that the language of reconciliation was a rhetorical approach deployed to ensure respectful dialogue in negotiations surrounding material recompense and Indigenous rights, however, the demands of Indigenous delegates were routinely marginalized, which calls into question the "reconciliatory spirit" supposedly conveyed by federal, provincial and Indigenous stakeholders. Moreover, Mulroney's quote not only discusses Indigenous issues but foregrounds reconciliation between federal and provincial stakeholders that contradict the very 
crux of constitutional reconciliation that requires the affirmation of a nation-to-nation relationship. ${ }^{37}$

In this section I have argued that Indigenous delegates advocated for constitutional reconciliation as a means to open pathways for economic redistribution. However, federal and provincial delegates positioned Indigenous peoples as both dependent and excluded from the nation-state's jurisdictional structure during the Constitutional Talks because Canadian sovereignty and economic prosperity would be undercut by the affirmation of Indigenous jurisdiction. Countering this, Mulroney's evocation of reconciling Indigenous-settler relationships was used to construct goals of "mutual beneficiaries" and "shared concerns" that would ensure a meaningful climate for capital accumulation that could benefit both Indigenous peoples and settlers. Yet, the Constitutional Talks were designed to address existing inequitable power relations as opposed to the creation of shared and mutual interests amongst stakeholders. Efforts to propose an investment in mutually beneficial economic development were primarily used federal and provincial representatives to bolster settler enrichment. In contemporary Canada, a focus on relationship building can disguise the ways that economic development is enacted at the expense of Indigenous peoples' self-determination (see Huseman and Short 2012; Preston 2013).

\section{The Cost of Doing Nothing: Social Investment}

Instead of affirming the Indigenous peoples' existing Indigenous rights that were embedded in the 1982 Constitution, the concept of reconciliation was used to signify the creation of new relationships with Indigenous peoples. Under the auspices of addressing Indigenous

\footnotetext{
${ }^{37}$ Indigenous self-government and self-determination was viewed as a controversial assertion to provincial stakeholders since Indigenous leaders "with strong nationalist positions demanded a relationship with the federal government alone. To them, dealing with the province was a denial of Indian sovereignty, or at least a dilution of the special constitutional status of Indian communities that flowed from section 91(24) of the Constitution Act of 1867" (Opekokew 1987, 36).
} 
peoples' supposed marginalization from the nation-state due to economic dependency, settler state representatives insisted that renewed relationships would help to strengthen the nation-state and foster mutual economic beneficiaries. Indigenous delegations' insistence on self-determination as a constitutional right led Mulroney to end Constitutional negotiations early, having deemed the First Ministers' meetings a political failure. Soon after, relationships between Indigenous peoples and settler Canadians became even more strained because of the 1990 standoff at the Pines in Kanesatake. ${ }^{38}$ As fraught relations played out in different confrontations and negotiations across the country, the Royal Commission on Aboriginal Peoples (RCAP) was initiated by the federal government.

The Royal Commission on Aboriginal Peoples was co-chaired by Rene Dussault and Georges Erasmus (who served as the National Chief of the Assembly of First Nations during the Mulroney era of the Constitutional Talks). Over five years, from 1991-1996, Commissioners travelled to each region of Canada to collect testimonies regarding their personal experiences and their perspectives on Indigenous-Canada relations. Among other things, RCAP's mandate emphasized:

The Commission of Inquiry should investigate the evolution of the relationship among aboriginal peoples (Indian, Inuit and Métis), the Canadian government, and Canadian society as a whole. It should propose specific solutions, rooted in domestic and international experience, to the problems which have plagued those relationships and which confront aboriginal peoples today. The Commission should examine all issues which it deems to be relevant to any or all of the aboriginal peoples of Canada. (RCAP Vol. 1 1996, 12)

Upon the completion of its mandate, the Commission created a 4,000 page final report that included over 440 recommendations designed to introduce positive policy and economic changes

\footnotetext{
38 The Standoff at the Pines was referred to by popular media outlets as "The Oka Crisis" occurred the summer of 1990 and lasted for 76 days and resulted in the death of one Quebec police officer. Indigenous residents of Kanesatake built a blockade to contest the expansion of a golf course on their traditional territory (see Ladner and Simpson 2010).
} 
that would inspire the reformulation of fraught Indigenous-settler relationships. The affirmation of Indigenous peoples' self-determination was central to these recommendations. ${ }^{39}$ The Final Report (1996) also summarized pervasive and ongoing problems that troubled Indigenous-settler relationships, such as: lack of consultation with Indigenous communities in policy and decisionmaking, jurisdictional constraints, denial of resource rights and the lack of a land base for Indigenous peoples' to pursue economic development.

The affirmation of a nation-to-nation relationship between Indigenous peoples and the settler state was cited as a key goal of the Royal Commission, but the economic benefits of reconciling relationships by the nation-state were also foregrounded in the Final Report (1996). This was partly because the Royal Commission on Aboriginal Peoples was launched during an era when Canadian economic policies were shaped by objectives of austerity or "roll-back neoliberalism," specifically in the form of funding cuts to public services. While discourses of "marginalization" that were so prominent during in the Constitutional Talks still prevailed in the Commission's Final Report (1996), Indigenous-settler relations were now explained through narratives of the "costliness" of inequality that presented suggestions that long-term national savings (elusive during a recession period) could be acquired through targeted public investments.

\footnotetext{
39 Some of the recommendations included "legislation, including a new Royal Proclamation stating Canada's commitment to a new relationship, and companion legislation setting out a treaty process and recognition of Aboriginal nations and governments; recognition of an Aboriginal order of government, subject to the Charter of Rights and Freedoms, with authority over matters related to the good government and welfare of Aboriginal peoples and their territories; replacement of the federal Department of Indian Affairs with two departments, one to implement the new relationship with Aboriginal nations and one to provide services for non-self-governing communities; creation of an Aboriginal parliament; expansion of the Aboriginal land and resource base; recognition of Métis self-government, provision of a land base, and recognition of Métis rights to hunt and fish on Crown land; initiatives to address social, education, health and housing needs, including the training of 10,000 health professionals over a ten-year period, the establishment of an Aboriginal peoples' university, and recognition of Aboriginal nations' authority over child welfare" (Hurley and Wherrett 2000, n. pag.).
} 
In this section I argue that the reconciliation of Indigenous-settler relations were framed by the Commission's Final Report (1996) through a narrative of social investment, an approach that was popularized during the 1990s by Anthony Giddens. According to critics of this approach, the "old welfare state" was created to "protect people from the market. A social investment, by contrast, would facilitate the integration of people in the market" (Jenson and Saint Martin 2003, 83) by emphasizing "social inclusion through work, individual responsibility and human capital investment" (Cantillon and Van Lancker 2013, 553). The social investment approach also insists that

it is acceptable for the state to spend generously when, and only when, it is behaving like a good business would, seeking to increase the promise of future profits. The goal, as that of any good business, is to increase the profit margin. Spending for current needs, in contrast, must be canny and limited. (Jenson and Saint-Martin 2003, 83-4)

Therefore, underlying this approach is an assumption that present spending is contained under the expectation of future surplus capital and to ensure a business-oriented approach to governance. The Commissioners suggested that Indigenous communities required interventions supported by robust social policy to help offset the ramifications of economic disadvantage and the inequitable distribution of resources that they experienced as a result of racist policies and dispossession. Nonetheless, the characterization of public investment lends itself to the reification of market relations and the implementation of economic strategies to solve social and political inequity.

I suggest that the deployment of investment discourses is complicated when read alongside the key concepts of renewal and reconciliation. According to Ladner and Dick (2008), "[w]ith the release of the Report of the Royal Commission on Aboriginal Peoples, a new language of relationship renewal and reconciliation has become predominant within government circles" (68). Despite the threat that these terms may be co-opted by the settler state, I assert that the Royal Commission on Aboriginal Peoples deployed reconciliation and renewal both earnestly and 
strategically. Reconciliation as defined by the Royal Commission of Aboriginal Peoples gestures towards "attempts to heal Aboriginal peoples and communities" (Turner 2013, 100). The Royal Commission of Aboriginal Peoples Final Report stated:

[B]efore Aboriginal and non-Aboriginal people can get on with the work of reconciliation, a great cleansing of the wounds of the past must take place. The government of Canada, on behalf of the Canadian people, must acknowledge and express deep regret for the spiritual, cultural, economic and physical violence visited upon Aboriginal people, as individuals and as nations, in the past. And they must make a public commitment that such violence will never again be permitted or supported. (RCAP Vol. 1 1996, 17)

According to the above quote, reconciling requires a public discussion of historical wrongs and a commitment from the settler state to never again inflict oppressive or violent policies on Indigenous peoples. Renewal, however,

depends on a renewed understanding of the historical relationship between Aboriginal nations and the Canadian state...This means that understanding the contemporary legal and political relationship requires a richer understanding of how colonialism has disempowered Aboriginal peoples. (Turner 2013, 104)

In this context, I read renewal as attending to the ongoing ramifications of these historical wrongs by reforming inequitable relationships and respecting the unique history of Indigenous-settler relations, specifically the distinct constitutional status of Indigenous peoples.

In outlining the central problems with Indigenous-settler relations in Canada, the Royal Commission on Aboriginal Peoples Final Report (1996) provided a twenty year plan entitled, Renewal is a Good Investment that detailed how to implement socio-economic change by outlining the benefits of adhering to these recommendations and the costs of ignoring them. The primary goal of this plan was to reduce the "costs of the status quo." To do this, the Commission demonstrated how current public policies designed to "help" Indigenous peoples were in fact costing the state more money because they reflected certain racist and colonial biases held by settler Canadians and the settler state. The twenty year plan recommended that spending on 
Indigenous social policy be increased by 1.5 billion dollars for approximately 15 years, and that within 20 years, the socio-economic gap existing between Indigenous peoples and settler Canadians would eventually be closed. The rationale behind this investment in social policy was the belief that "[e]ventually, savings and new tax revenues will equal and then exceed the cost of the strategy" (RCAP People to People 1996, n. pag.). An "investment in renewal" would ensure that:

Aboriginal people will gain by achieving greater productivity and higher incomes. Other Canadians will gain through reduced government spending and increased government revenues. Political, economic and social renewal can help Canada balance its books. Our proposals will cost money, but they will also save money. Eventually, savings and new tax revenues will equal and then exceed the cost of the strategy. We estimate that it will take between 15 and 20 years of investment to reach that point. (People to People 1996, n. pag.)

This quote, taken from the Final Report (1996), encourages the government to invest in social programs that will balance the budget, generate advantages and savings for all Canadians. I observe here that justice and inequality are financialized in order to appeal to settler and elite interests. Waslander summarizes the appeal to settler interests by suggesting that

the Commission describes and analyzes the appallingly bad social and economic conditions facing Aboriginal people, and makes recommendations designed to bring about change for the better. In this context, the Commission argues that improvement in the living standards and well-being of Aboriginal people will also be advantageous to Canadians. Canadians may derive satisfaction from social justice; they would also gain financially. (Waslander 1997, 960-1)

The above quote outlines how the Commission used an incentive strategy by outlining possible affective and financial return on public investment. The affective return that settler Canadians would derive from "investing in renewal," however, does not question the history of violence or the coloniality of power that operates in Canada. In deploying this investment strategy, the Commission invites state officials to rely on "improving outcomes within the existing framework of government intervention and social structures," a strategy that has historically failed because 
"[t]his needs-oriented mindset is loaded with ideological assumptions that defend the dominant ideology" (Maaka and Fleras 2005, 272). The deployment of investment discourse in this context has political ramifications for Indigenous people, namely that settler-Canadians must be incentivized to work towards socio-economic change and to rectify historical injustice.

To calculate an "investment in renewal," the Royal Commission employed a cost/benefit analysis of several social programs. In doing so, the final volume of the report summarized visible problems and outlined a number of interventions designed to initiate social change. The logic deployed by RCAP is used to sketch the beneficial outcomes for the settler state and Canadian citizen, should a strategic public investment be made to address the socio-economic crises in Indigenous communities. Accordingly, the Final Report (1996) states that

gains from the strategy will take the form of increased incomes for Aboriginal people and a fiscal dividend for governments. Governments will see their revenues increase, as Aboriginal economic activity expands, and their expenditures on financial assistance and remedial programs decline as Aboriginal people's dependence on government diminishes. (RCAP Vol. 5 1996, 52)

According to the Royal Commission's Final Report, a set of social costs have been incurred through "inequitable and counter-productive policies of dispossession and assimilation of Aboriginal peoples" (RCAP Vol 5 1996, 21). The public costs of illness, vice, or violence are primarily calculated in the Final Report (1996) in two different ways: through a lost contribution to economy (estimated through unemployment rates or missed work days), and through the individual's dependence on social services such as healthcare, legal services, or unemployment programs.

The framework for establishing "loss" requires the determination of criteria to measure tangible and intangible "costs" to the state that are referenced as burdens to the responsible and fully employed taxpayer (see Hankivsky 2004). The Commission's Final Report (1996) notes that 
"[s]ocial costs fall into two broad categories: costs associated with the economic marginalization of Aboriginal people, and costs incurred as governments attempt to address social problems through remedial programs" (RCAP Vol. 5 1996, 21). These two categories, called Foregone Production and Government Expenditures: The Burden of Remedial Costs, outlined costs that "are borne collectively by all Canadians," and that "continue to be incurred year after year and will escalate as long as current policies are in place" (RCAP Vol 5 1996, 21), and primarily affect the taxpayer. ${ }^{40}$ The first category used by the Royal Commission, later referred to as Forgone Production, was measured by three main categories: labour participation, unemployment rates and potential earnings from labour.

The Royal Commission's Final Report (1996) noted that labour participation was lower amongst Indigenous peoples in relation to settler-Canadians, unemployment was higher and potential earnings were lower, as Indigenous peoples were often found in lower-wage labour jobs where earning potential was curtailed. According to the RCAP report " $[\mathrm{t}] \mathrm{o}$ achieve parity with all Canadians in the rate of employment, 82,000 more Aboriginal people would have to have been employed. At Aboriginal people's earning rate in 1990, this extra employment would have brought in $\$ 1.8$ billion in income and narrowed the earnings gap by almost half (48.6 per cent)" (RCAP Vol. 5 1996, 23). The analysis of income disparity was conducted in regards to access to jobs, but RCAP is also careful to account for inequitable access to social resources such as healthcare and

\footnotetext{
${ }^{40}$ While I see the importance of pointing out the wastefulness and oppressive nature of government processes, the argument of economic costs may bolster assumptions about Indigenous peoples as "troublemakers." For instance, a "cost/benefit" analysis concerning the lack of progress made in the Comprehensive Land Process was made by the Auditor General in 1998. In this context, the taxpayer was identified as a victim of economic burdens of settling claims whereas the reality of Indigenous peoples' daily disempowerment and impoverishment was of less concern (Samson and Cassell 2008, 38). By positioning the Canadian settler as the victim of economic exploitation through the settlement of legitimate grievance or justice claims, the process is immediately deemed costly to the state, which may encourage a backlash against Indigenous peoples. At the same time, the Auditor General's Report (1998) does demonstrate a contradiction in the governmental commitments to "cost-effective" programming while they participate in the delay of land claims settlements (see Samson and Cassell 2008).
} 
education opportunities as an obstacle to Indigenous job seekers. Therefore, an "investment in renewal" functions as a set of strategies mobilized to stimulate the economic system by incorporating Indigenous peoples into the wage economy and the political system. This coincides with a social investment logic because, as Cantillon and Van Lancker (2013) suggest,

[1]abour market integration is not only regarded as a superior way to achieve income protection and social inclusion at the individual level, but it is also an indispensable feature of "productive" social policy systems because higher employment levels decrease benefit dependency and contribute to sound public finances, and hence the future sustainability of the welfare state. (553)

Labour market inclusion was suggested as the primary means to generate revenue in Indigenous communities and to minimize financial burdens to the state. I suggest this framing of historical injustice can be viewed as a reproduction of coloniality because the structural components of inequality and discrimination are obscured by the calculation of costs. The valorization of labour and production allows proposed solutions to be read through the lens of finance, which opens social reform up to the dictates of capitalist logic. Moreover, the space to address the role of capitalist economic development in creating inequality and exacerbating discrimination in the first place is undermined through the use of investment discourse in the context of Foregone Production (see also Hankivsky 2004).

In the Government Expenditures: The Burden of Remedial Costs section, the Final Report (1996) observed a high level of government spending in Indigenous communities in comparison with non-Indigenous communities. The programs examined in this section were twofold, including "programs that provide financial assistance to persons in need and remedial programs. The former are intended to meet basic human need and include social services, other forms of income transfers and housing subsidies. Remedial programs protect society, enforce the law and help individuals, families, and communities cope with social personal and health problems" (RCAP Vol. 5 1996, 
38). This section of the report provides statistics depicting increasing revenue, such as a $183 \%$ growth in expenditures from Aboriginal programs from 1981-82 to the 1991-92 federal budget (RCAP 1996 Vol. 5, 31). The Final Report (1996) also suggests that 0.8 billion dollars was directed towards financial assistance programs for Indigenous peoples in the 1992-3 federal budget, and spending on remedial programs that same year was 1.4 billion, to rise to 1.7 by the end of 1996 (RCAP Vol 5 1996, 41). In demonstrating the spending on remedial programs, the Royal Commission on Aboriginal Peoples used language that pathologized Indigenous communities in order to demonstrate a crisis produced by colonial policies and attitudes. The Final Report (1996) suggests that "[i]f Aboriginal people were healthier of body and spirit and their families less troubled, they would require less in the way of healthcare and social services, and there would be fewer cases of Aboriginal people in conflict with the law" (RCAP Vol. 5 1996, 41). Understandably, it is important to draw attention to suffering in Indigenous communities as a result of discrimination and inequity, but uncritical popular narratives of the "pathological Indigene" persist in media representations of Indigenous communities.

As I noted above, investment discourse was also used by the Royal Commission on Aboriginal Peoples to counter the increasing austerity measures ${ }^{41}$ that were being implemented at all levels of government. The Final Report (1996) pointed out that ongoing stratification of Indigenous peoples and settlers was maintained by increasing funding cuts. A reliance on austerity logic was challenged by Commissioners, who asserted:

We are also concerned that expenditure reductions will diminish spending on services, such as social housing, that are vital to enable Aboriginal people to cope with deteriorating conditions in their communities. Worse, cutbacks in economic development programs and the levelling off of the training budget mean that less effort is being made to improve economic conditions for Aboriginal people. We fear that governments, facing further

\footnotetext{
${ }^{41}$ I use the word austerity here to represent what political economists (Peck and Ticknell 2002; Graefe 2005) refer to as roll-back neoliberalism. This type of neoliberalism is characterized by massive cuts to social spending and the privatization of services that were at one time operated by the government.
} 
restraint, will not make the investments necessary to eradicate poverty among Aboriginal people and improve their living conditions. (RCAP Vol 5 1996, 33.)

In this quote, RCAP suggests that public investments encourage redistribution to Indigenous peoples and, therefore, funding commitments to social programming should not be assaulted by the imposition of roll-back neoliberalism. The Final Report (1996) states:

Governments should not ignore their obligations to Aboriginal people just because their role in society is being redefined. It would be a travesty of justice if concerted and effective action to correct the history of oppression and dispossession of Aboriginal people were set aside on grounds of financial restraint just at the point when this history is finally being recognized for what it is. (RCAP Vol 5 1996, 55.)

The underlying message of Investing in Renewal was that the settler state needed to recognize a moral and constitutional obligation to Indigenous peoples that could not be denied by cost-saving ideologies. Therefore, while the social investment model utilized by the Commission has negative ramifications for Indigenous peoples, such as the economization of justice, one must not overlook the Commission's strategic attempts to hold the settler state to account for historical injustices by drawing attention to the disadvantage of imposing austerity measures on Indigenous peoples.

I assert that the Royal Commission on Aboriginal Peoples mobilized a social investment paradigm in their Final Report (1996) as a strategy to ensure a robust contribution to social welfare and social policy. Fiona Williams notes that social investment strategies highlight the need for structural change, but she also cautions that the terminology of social investment may not secure social justice goals, as it emphasizes "a strategy to enhance self-sufficiency, economic competition and social inclusion" (Williams 2012, 107). Not unlike the discourses of dependency and development which circulated during the Constitutional Talks in the 1980s, the perception that Indigenous peoples are marginalized can help to strengthen nation-building projects. However, the Final Report (1996) acknowledges disparity amongst different regions and peoples, and thereby advocates for redistributive measures to ensure that Indigenous people have access to wealth 
without having to relocate from their traditional territories. In significantly breaking from the social investment approach, the Commission argued that an investment in social policy should be linked to the extension of Indigenous peoples' jurisdiction over their lands and lives. For instance, the Final Report (1996) notes that renewal could be accomplished through "[i]mplementing selfgovernment and acquiring an increased land base," because these policy changes will effectively "generate a powerful momentum for economic self-reliance" (RCAP Vol. 5 1996, n. pag.). Despite the importance of advocating for Indigenous rights and land transfer, the potentially negative consequences of utilizing the investment logic in the Final Report (1996) are obvious in the government's response to the Commission's findings.

In 1998, the government released its response to RCAP: Gathering Strength: Canada's Aboriginal Action Plan, and in this document the logic of Renewal as a Good Investment is replaced with the concept of Investing in People. Subsumed under the heading of "Supporting Strong Communities, People, and Economies," calls for public investment are now presented as strategies that privilege the individual. The promise here is that " $[\mathrm{t}]$ he government will work in partnership with Aboriginal people to support individual, family and community well-being" (Canada 1998 a, 16). In Gathering Strength (1998), social problems are reduced to the contributions of individual citizens or "private" interests. For instance, Investing in People is a policy recommendation dedicated to "assisting [Indigenous] individuals to acquire the education, skills and training necessary for individual self-reliance" (Canada 1998 a, 16). In neoliberal approaches, "[i]ndividual success or failure are interpreted in terms of entrepreneurial virtues or personal failings (such as not investing significantly enough in one's own human capital through education) rather than being attributed to any systemic property (such as class exclusions usually attributed to capitalism)" (Harvey 2005, 66). Gathering Strength (1998) deployed a form of roll- 
out neoliberalism that dictated policy goals by outlining appropriate citizen behaviours, where individuals were made responsible for their own well-being and prosperity instead of relying on state support.

In this section, I have argued that the Royal Commission on Aboriginal Peoples articulated the concepts of reconciliation and renewal through the lens of investment. The concept of investment was used to address funding shortfalls in social policy for Indigenous peoples particularly with the imposition of roll-back neoliberalism. However, the government's response to the Royal Commission on Aboriginal Peoples' Final Report reinforced neoliberal logic. Indigenous peoples' "problems" were characterized through "community" pathology and individual citizens were made responsible for "getting better" and contributing to Canadian society. Moreover, the social investment approach affirmed rather than contested mainstream economic doctrine, as it was deployed to outline the ways that settlers could benefit from implementing social justice policies. The result of this approach was Gathering Strength's (1998) insistence that a contribution to the economy is necessary for the creation of mutual beneficiaries and a robust nation-state. Through increased labour market participation was an exercise in rollout neoliberalism, where citizens were pressed to exhibit certain "responsible" behaviours to ensure their health and prosperity.

The Royal Commission's use of investment logic made their recommendations for social investment vulnerable to neoliberal co-optation, particularly with regard to their discussions of Forgone Production and Remedial Spending. Moreover, claims to collective rights for territory and governance located in the concept of Renewal were bypassed in Gathering Strength (1998), in favour of an emphasis on individual economic success that mutually benefits Indigenous peoples and settler Canadians alike. As I will argue in the next section, reconciliation initiatives that 
emerged from Gathering Strength (1998) were used to contain the demands for renewal that incorporated the extension of land, jurisdiction and restitution to Indigenous peoples. However, the convergence of settler colonialism and neoliberalism was solidified during the late 90 s where demands for redress are confronted by the legacy of economic recession. The convergence of these projects created a political and economic climate where reparative expenditures were necessary but also required containment and the assurance of a financial return.

\section{No Pain, No Gain: Therapeutic Investment}

Through an emphasis on the costliness of remedial spending and foregone production, a narrative of Indigenous peoples' dysfunction and the need to "get better" ran throughout the Royal Commission on Aboriginal Peoples five-volume report. In the Final Report (1996), the legacy of residential schools was a documented cause of the addictions, trauma and dysfunction still being experienced by Indigenous peoples in contemporary Canada. To combat this legacy of violence and suffering, the extension of material restitution to Indigenous peoples was recommended. As I have argued, the IRS system functioned as a disciplinary investment, however, the final section of this chapter examines how the monies dedicated to reparations for Indigenous peoples function as a therapeutic investment for the settler government. Gathering Strength (1998) serves as a guiding document for the creation and implementation of this type of investment. I document how Canada's “Aboriginal Action Plan" employed neoliberal values that individualize grievance and trauma in order to contain the project of reconciliation (see also Green 2012; Henderson and Wakeham 2009). As I argued in the previous section, in order to calculate misspent government monies, the Royal Commission on Aboriginal Peoples documented high levels of poverty, addiction and dependency on state services in Indigenous communities. These issues were recorded alongside statistical evaluations of structural inequalities, such as high rates of 
incarceration and children in care. In demonstrating the need for both preventative and reactive public investment, Indigenous suffering and pain were deemed "costly" to the Canadian government and taxpayer as a strategy to provoke action.

The Royal Commission demanded that the settler state "must fully support Indigenous peoples' 'well-being,' a holistic concept that included self-government, self-reliance, a partnership of mutual respect with Canada, and healing" (People to People 1996, n. pag.). Yet, when healing is addressed later in Gathering Strength (1998), it is discussed in the following way:

The Government of Canada is also committed to assisting in community healing to address the profound impacts of abuse at Residential Schools. Healing initiatives will be designed in partnership with Aboriginal leadership and victims groups, and will be delivered in the broadest possible fashion to all Aboriginal people, including Métis and off-reserve individuals and communities that have been impacted. (Canada 1998 a, 5)

Gathering Strength (1998) approached healing by way of the residential school context and through discourses of individual victimhood. Where the Royal Commission asserted a need for "healing" to tackle ongoing individual suffering and to promote structural change; Gathering Strength (1998) emphasized the need for Indigenous peoples to emerge from impoverished conditions to "heal" from the legacy of abuse.

I note scholarly caveats that claim that the language of healing can be used to represent "a semblance of common ground or shared understanding" (Henderson and Wakeham 2009, 16) between Indigenous peoples and settler Canada, but it is also important to note the slipperiness of this concept when it functions as a biopolitical discourse used by the settler state to "reconstruct" and "manage" Indigenous communities (Million 2013, 150). The concept of healing remains highly contested in the context of Indigenous-settler relations, because its public usage often implies an illness or sickness experienced by Indigenous peoples that needs to be cured (see Green 2012; Henderson and Wakeham 2009; Episkenew 2010; Million 2013). For instance, the 
"sickness" of Indigenous peoples is often presented as a social or cultural problem in the popular settler imagination. For this reason, Cree scholar Jo-Ann Episkenew $(2010,6)$ deploys healing to reverse the pathologization of Indigenous peoples by instead presenting settler colonialism as "sick."

Building on Henderson and Wakeham (2009), I concur that what is ultimately "at stake" in the deployment of healing is its "relation to decolonization" (16). Unpacking the relationship between these two concepts, Elisabeth Middleton (2010) suggests that

the term 'healing' [is] used to refer to emotional and spiritual processes, which include conscious and holistic recovery, recognition, and re-building within Native [sic] individuals, families, communities, and nations. Healing includes personal efforts to acknowledge the effects of historical trauma in multiple aspects of one's liferelationships, health, etc.- and then conscious work to change any negative patterns in which one might be passing on the trauma. Decolonization, on the other hand, involves a larger socio-political project of examining and working to dismantle coloniality in multiple arenas, including epistemic, social, political, and economic. Healing may seem impossible without some decolonization. (11)

Middleton's description of healing as a necessary response to historical injustice is dependent on both personal recovery and on substantive structural change. Therefore, as I argue elsewhere (Green 2012), Indigenous concepts of healing retain a radical critique of coloniality that is not only useful in addressing historical injustice, but also in conceptualizing self-determination (see also Cowlishaw 2003; Gone 2009; Episkenew 2009; Wesley-Esquimaux 2005). Indigenous healing discourses also identify misconceptions about the endemic trauma in Indigenous communities by identifying colonialism as a social determinant of health (see Nelson 2012). In Middleton's quote decolonization must precede healing for recovery to take place, yet as I outlined above, the conceptualization of healing found in Gathering Strength (1998) seemingly bypasses decolonial demands to instead focus on recovering from suffering induced by the legacy of residential schooling. Therefore, I argue that a confrontation between healing and therapy is central to the 
deployment of atonement and reparations that characterizes this most recent era of reconciliation (see also Million 2013; Mackey 2013; Winter 2011).

With the release of Gathering Strength (1998), reconciliation became subsumed under a rubric of multiple and concomitant politics associated with the extension of reparations, namely, the politics of atonement, the politics of healing, and later, the politics of compensation. What all three of these reparative projects have in common is a focus on Indigenous peoples' victimization, dysfunction and harm. Firstly, the Aboriginal Healing Foundation was introduced as a major strategy in Gathering Strength (1998); and secondly, a public Statement of Reconciliation was made by the Minister of Indian and Northern Affairs in 1998. By 1999, a series of pilot projects for an Alternative Dispute Resolution Mechanisms were set up in several communities across Canada to test the potential for a state-sponsored compensatory mechanism. These strategies have been described as "redress as therapy," which indicates that all three state strategies focused on the need for individual healing as opposed to socio-economic change (Winter 2011; see also Green 2012; Henderson and Wakeham 2009; Nagy 2012). While these strategies were designed to address the historical injustice of residential schooling in a public way, they were imbued with therapeutic components that were employed to contain and individualize narratives of suffering and perpetration, to situate Indigeneity alongside victimhood, and limit the possibility for substantive structural change that would be required to cultivate Indigenous peoples' "well-being" that the Royal Commission had painstakingly recommended.

Following the release of Gathering Strength (1998) the government of Canada addressed Indigenous experiences of historical injustice by issuing a Statement of Reconciliation (1998). In 
this statement, the Minister of the Department of Indian Affairs, Jane Stewart, ${ }^{42}$ acknowledged a history of oppression that existed between Indigenous peoples and settler Canadians:

Sadly, our history with respect to the treatment of Aboriginal people is not something we can take pride in. Attitudes of racial and cultural superiority led to a suppression of Aboriginal culture and values. As a country we are burdened by past actions that resulted in weakening the identity of Aboriginal peoples, suppressing their languages and cultures, and outlawing spiritual practices. We must recognize the impact of these actions on the once self-sustaining nations that were disaggregated, disrupted, limited or even destroyed by the dispossession of traditional territory, by the relocation of Aboriginal people, and by some provisions of the Indian Act. We must acknowledge that the result of these actions was the erosion of the political, economic and social systems of Aboriginal people and nations. (Canada 1998 b, n. pag.)

While the Statement of Reconciliation demonstrated that injustices committed against Indigenous peoples were part of a larger political project that was initiated by the settler state (see Henderson and Wakeham 2009; Woolford 2008), others have noted that substantive action did not accompany this speech act, leaving demands for restitution and structural change unrealized (see Alfred 2008; Holder and Corntassel 2008). I characterize the Statement as a therapeutic investment, because wrongdoing was acknowledged by the perpetrator but it was not accompanied with a pledge of resources that would institute substantive structural change (see James 2006). This is consistent with Claire Moon's (2009) caveat that “therapy sidesteps redress for the deep structural and economical inequalities within which makes gross violations of human rights become possible, because it concentrates instead on changing people's behaviour through altering their selfperception" (80). The politics of atonement deployed throughout the Statement of Reconciliation safely places the harms committed against Indigenous peoples in the past and thereby denies action that can be taken in the present to adjust the structural and systemic inequality that the Royal Commission documented two year previous. The containment of this history potentially endangers

\footnotetext{
42 Former Prime Minister Jean Chretien was noticeably absent from the reading of the Statement of Reconciliation in 1998.
} 
the reconciliation of Indigenous peoples and settler Canadians because as Leanne Simpson (2012) suggests: "[i]f reconciliation is focused only on residential schools rather than the broader set of relationships that generated policies, legislation and practices aimed at assimilation and political genocide, then there is a risk that reconciliation will 'level the playing field' in the eyes of Canadians" (21). In framing Canada's history of colonial policies in this manner, the settler state permits this legacy to be comfortably situated as a folly of the past, thereby allowing the contemporary inequalities that Indigenous people experience be associated with psychological and community dysfunction.

Gathering Strength (1998) provided a significant material investment in acknowledging and addressing the legacy of historical injustice committed against Indigenous peoples, specifically in relation to the experience of residential schooling. A 350 million dollar endowment was dedicated to the creation of a healing fund to provide healing support services and counselling to former residential school students. The endowment was overseen by an Indigenous led organization that would eventually become the Aboriginal Healing Foundation. This organization, which is the subject of Chapter Six, would fund culturally based healing programs that were designed and implemented at the community level by Indigenous peoples themselves. However, the Aboriginal Healing Foundation was also hamstrung by a narrow mandate so that the organization's programs were limited to "addressing the legacy of physical and sexual abuse" (Canada 1998 a, 4). This approach has been criticized by many scholars that have suggested that the limitations of the organization's mandate enabled the individualization of the experience of physical violence and sexual assault experienced by Indigenous children as well as acts of perpetration (see Green 2012; Henderson and Wakeham 2009; Nagy 2012). According to this rationale, residential school abuses, and the perpetrators of these abuses, were deemed to be 
"exceptions" to the residential school process instead of characteristic of the experience of internment and removal. By presenting the residential school system as a set of unfortunate, but individual, circumstances, the settler state sought to underplay the relationship between the exploitation of children in residential schools and the oppression of Indigeneity writ large in Canada's history.

The Aboriginal Healing Foundation also introduced the language of trauma into the public lexicon. The harms experienced by former students of the residential schools are now professionally and popularly understood through this lens. ${ }^{43}$ In conceptualizing residential school trauma, Indigenous peoples have defined trauma by linking health with justice, and in doing so, have created a clear articulation of collective damage inflicted by Canadian colonialism. Trauma, as understood through a Western psychoanalytic lens, relies on the analysis of an event-based experience that is marked by intrusive and ongoing flashbacks which deeply disturb the everyday life of the afflicted individual. Drawing on Freudian theories, Ruth Leys (2000) asserts that "trauma was originally a word for a surgical wound, conceived on the model of a rupture of the skin or protective envelope of the body resulting in catastrophic global reaction in the entire organism" (19). This perpetual maelstrom of psychic disruption can only be averted through the narration of these experiences in an effort to safely situate invasive memories in the past (Caruth 1995; Herman 1992; Schwab 2006). These afflictions are generally diagnosed by a "qualified" medical expert, mostly notably a Western practitioner of psychotherapy.

While Indigenous scholars and practitioners present trauma as catastrophic for the individual, they treat the experience as a social phenomenon rather than a medical condition because, in the latter context, trauma may become detached from collective and historical

\footnotetext{
${ }^{43}$ Dian Million provides an exceptionally detailed history of this term's usage in her book Therapeutic Nations (2013).
} 
experiences of oppression (Brave Heart 2003; Duran 2006; Episkenew 2009; Million 2013).

Disentangling trauma from coloniality is of particular concern when the term "Post-Traumatic

Stress Disorder" is mobilized to describe former students' experiences. ${ }^{44}$ The diagnosis for Post-

Traumatic Stress Disorder appeared in the DSM III in 1980, and was defined by diverse physical and psychological symptoms ranging from nervousness, flashbacks, headaches, rage, and listlessness. PTSD has now been modified by Canadian practitioners to explain the physical and mental maladies associated with residential school experiences. This adapted condition has been aptly named Residential School Syndrome (Brasfield 2001) ${ }^{45}$ This catch-all diagnosis has been rejected by other health scholars who observe that trauma discourses individualize Survivor experiences and render the victim powerless in perpetuity (Adelson 2000; Blackburn 2012; Episkenew 2009; Gone 2008; Million 2013).

To unsettle the relationship between individual victimhood and trauma, many Indigenous scholars have opted for defining trauma in relation to colonial violence as opposed to an individual symptomology. Terry Mitchell and Dawn Maracle argue that PTSD

\footnotetext{
44 During the South African Truth and Reconciliation Commission, the use of this diagnostic paradigm was critiqued because it gave "moral substance" to the granting of amnesty to perpetrators, because these "processes often articulate perpetrators of atrocity as victims" (Moon 2009, 74). According to Moon, Post-Traumatic Stress Disorder was first introduced into the public lexicon after the Vietnam War to describe the ongoing effects of soldiers returning from the battlefield. Like Moon, Kali Tal (1997) questions the position of "the combat soldier simply in the victim's role; helpless in the face of war, and then helpless to readjust from the war experience upon his return home...The solider in combat is both victim and victimizer; dealing with death as well as risking it. These soldiers carry guns; they point them at people and shoot to kill. Members of oppressed groups, by contrast, almost never control the tools of violence" (10). Nonetheless, trauma associated with perpetration is not unknown to the theorization of colonialism, for instance, Frantz Fanon's The Wretched of the Earth (2004) details the psychological responses of both victims and perpetrators of violence.

45 According to L.H. Robertson (2006) "Residential School Syndrome is a subtype of PTSD which focuses on intense feelings of fear and anger and the tendency to abuse alcohol and drugs" (9). He goes on to suggest that the concept of historic trauma "minimizes the importance of the residential school experience by placing that experience within a pan-Aboriginal frame. All Aboriginal peoples share the same genocidal history, and that historic shared experience is paramount in understanding Aboriginal social and mental health issues. From this perspective, specific conditions such as depression, alcoholism, anxiety, suicide ideation, and anger management problems are merely symptoms of a larger malaise" (Robertson 2006, 11).
} 
is not suitable for describing the Indigenous peoples' response to historical trauma and suggest another term "post-traumatic stress response" (PTSR). They explain that the term PTSD "individualizes social problems and pathologizes traumatized people"; whereas PTSR as "diagnostic profile provides a useful tool in confirming the long-term impact colonization, which may increase access to appropriate healing resources." (qtd. in Episkenew 2009, 9)

By re-constituting this PTSD paradigm, Mitchell and Maracle subvert the pathologization of Indigeneity by situating illness as a collective response to the policies and practices implemented by the settler state. In re-framing trauma in this way, bad health become synonymous with colonial violence and the need for Indigenous peoples' good health is presented as a matter of justice. Historic trauma is a term that has been used by the Aboriginal Healing Foundation, and is defined as a cluster of traumatic events and as a disease itself. Hidden collective memories of this trauma, or a collective non-remembering, is passed from generation to generation, as are the maladaptive social and behavioural patterns that are symptoms of many social disorders caused by historic trauma. There is no "single" historic trauma response; rather, there are different social disorders with respective clusters of symptoms. (Wesley-Equimaux and Smoleski 2004, iv)

Western conceptualizations locate the experience of trauma within the individual, whereas Indigenous conceptualizations of trauma suggest that attention needs to be paid to broader structural violence and substantive systemic change.

Describing these egregious experiences of residential schooling as traumatic can also be strategic, in order to alert the settler society to the consequences of residential school policies. Arguably, this is the practice of organizations such as the Aboriginal Healing Foundation whose mandate is to educate the settler society about the extensive damage done by the residential school system. However, while Indigenous peoples' definitions of trauma are more frequently used to articulate the devastating effects of colonization, the narrative of harm and trauma has been taken up by settler and neoliberal projects to curtail the realization of Indigenous peoples' goals. The 
consequences of these trauma "diagnoses" can be acutely felt in the deployment of compensation through the state-sponsored Alternative Dispute Resolution Mechanism.

In 2000, a survey was conducted by Earnscliffe and Pollara to assess the opinions of Canadian citizens regarding the Indian Residential School system. Respondents insisted that compensation to former students was necessary and that the government and churches were responsible for providing such compensation. Public support for compensating former students was bolstered by several public reports that had been released by a leading legal think tanks. ${ }^{46}$ To assess the damage caused by residential schooling, emancipatory accounting techniques and cost/benefit frameworks were again utilized by legal organizations to assess the "need" for reparations. Advocacy and non-governmental organizations released reports to expressly analyze the "economic costs" of specific pathologies, illnesses, or deviant behaviours to the Canadian citizenry. ${ }^{47}$ The public costs of illness, vice, or violence are primarily calculated in two different ways: through a lost contribution to economy that is estimated through unemployment rates or missed work days or through the individual's dependence on social services such as healthcare, legal services, or unemployment programs.

While reparations are not originally positioned as an investment per se, the argument to extend these processes gestures to investment rationale. For instance, the Law Commission of Canada's report Needs and Expectations for Redress of Victims of Abuse (1998) suggests that “[c]ompensation must recognise lost education, lost earning potential, and lost achievement

\footnotetext{
${ }^{46}$ The most prominent of these think tanks was the newly appointed Law Commission of Canada (1997), which was a research body that provided recommendations concerning Law Reform to the federal government. The Law Commission of Canada was disbanded in 2006 due to funding cuts imposed by the Conservative Government of Canada.

47 Numerous reports include Economic Burden of IIIness, 1993; "The Costs of Smoking," 1991; The Economic Burden of HIV/AIDS in Canada, 1998; Money Well Spent: Investing in Preventing Crime, 1996; and "Economic Costs of Schizophrenia in Canada: A Preliminary Study," 1995.
} 
potential of survivors; compensation must address poverty as one result of residential schooling; compensation is needed to pay for helping, counselling and legal services" (69). However, scholars have suggested that individual compensation payments should be combined with institutional and systemic change to avoid band aid solutions for Indigenous peoples (see Alfred 2012; Green 2012; Nagy 2012). In a 2000 report, entitled Restoring Dignity: Responding to Child Abuse in Canadian Institutions, the Law Commission suggested that an alternative dispute resolution mechanism was a more beneficial approach for survivors of institutional abuse than litigation, because these processes "are usually less costly, less time consuming, and less complex than civil action" (160). Not unlike the Royal Commission on Aboriginal Peoples, the need for reparations was placed within a cost/benefit framework. This emancipatory accounting approach was employed to ensure that the settler state is held accountable for egregious crimes that were committed. The way in which this framing of the "need" for reparations led to the applications of an investment rationale being applied to reparations is the subject of my next chapter. Nonetheless, as I will demonstrate in the following chapter, under the Harper Government the implementation of reparations was soon disciplined to achieve neoliberal goals.

In 2003, an Alternative Dispute Resolution Mechanism was introduced by state authorities to initiate an adjudicative process that provided compensation to former residential school students. An Alternative Dispute Resolution model of justice focuses on the compensation of harms, instead of delivery of punishment to perpetrators, as the primary practice of retributive justice (Law Commission 2000, 99). This process employed a tort framework to guide the understanding of harm and compensation, referring "to laws that allows an injured person to obtain compensation from the person who caused the injury....Tort law is used as a deterrent by holding people responsible for their actions and educating them about what conduct is acceptable" (Alberta 
2016, n. pag.). This model "requires the wrongdoer to put the plaintiff in the position that she would have been in had the wrong not occurred. Because the defendant can only be liable to repair those harms that are the consequence of her own wrongdoing, the court must distinguish the harms that flow from the legal wrong from all other harm" (Mayo 2014, 546). I draw attention to the deployment of the tort model because of its focus on harm instead of perpetrator accountability. Again, the focus is on the harm and dysfunction that is linked to the public conceptualization of Indigeneity as broken, sick or traumatized. The construction of trauma and injury in the context of residential schools compensation is contentious because this terminology has linked Indigeneity with victimhood (Blackburn 2012; Million 2013). Carol Blackburn (2012) argues that the conflation of trauma and Indigenous identity may compromise the formulation of "a strong position from which to assert rights to self-government and control over lands and other resources;[since] a population in permanent need of social services from the outside is not going to be seen as capable of governing itself" (299). ${ }^{48}$ Testifying to harm in order to apply for compensation, Indigenous peoples' experience of trauma may be labelled as an endemic cultural flaw. I will explore this argument in greater detail in Chapter Four.

In this section I have documented how demands for public investment to initiate structural change found in the Royal Commission of Aboriginal Peoples transitioned to a facilitation of reparations. However, when counselling and compensation payments were provided to individuals, their ability to alter hierarchies of systemic privilege and oppression was undermined. While Indigenous conceptualizations of trauma and healing embraced decolonial goals, they were marginalized in the deployment of reparations since government initiatives favoured a therapeutic approach to reconciliation. I have argued that Statement of Reconciliation, the healing fund

\footnotetext{
48 Not unlike the deployment of "investment" used by the Royal Commission on Aboriginal Peoples, the deployment of "trauma" as a narrative to raise public consciousness is double-edged.
} 
(Aboriginal Healing Foundation) and the state-sponsored Alternative Dispute Resolution each require problematization for two reasons: the experience of trauma and perpetration remains the focal point and only individual reparations for personal harm are extended. The emphasis on harm instead of perpetration has led to a denial of state accountability, which I explore further in the following chapter.

\section{Conclusion: Investing in Reconciliation}

In this chapter, I have demonstrated how Indigenous peoples have routinely advocated for public monies to secure an investment in social justice and substantive structural change. The demand for public investment was made in conjunction with the demand for extended political and territorial jurisdiction to support Indigenous self-determination. Yet, routinely the settler state has re-articulated demands for decolonization and restitution through discourses of investment that re-affirm Canada's "jurisdictional imaginary" (Rifkin 2009), ${ }^{49}$ the supremacy of market relations and the importance of "normalizing" Indigenous communities. Speaking more broadly, investment rationale was utilized to bypass Indigenous peoples' claims to extended jurisdiction and nationhood that have historically been perceived as a threat to the Canadian nation-state, an affront to Indigenous-settler partnerships, and a disruption to Canadian economic development.

Firstly, investment rationale was deployed by Indigenous peoples during the Constitutional Talks to contest prevailing assumptions that the solution to Indigenous peoples' "marginalization" from the nation-state was further integration. The settler state responded by conflating

\footnotetext{
49 According to Rifkin (2009), the jurisdictional imaginary describes material and affect practices that subsume Indigenous subjects under the legal and political authority of the settler state. This jurisdictional imaginary denies the existing rights of Indigenous peoples and quests for territory and jurisdiction are then presented as an affront to the nation-state and settler Canadians and threatening to the national economy.
} 
reconciliation and economic investment in an effort to contain Indigenous grievances and maximize economic outcomes for the nation-state. Secondly, the Royal Commission on Aboriginal Peoples utilized investment logic to demonstrate how costly inequality and oppression was to the settler society, and expressed the need for holistic policy approaches to encourage substantive structural change. Here the settler state responded by highlighting the need for individual responsibility and contribution to the nation-state whilst justifying the implementation of austerity measures. Thirdly, investment rationale was circulated by the settler state to ensure that Indigeneity was marked with a narrative of dysfunction in order to undermine Indigenous resistance and to individualize the repayment of the debt of historical injustice. Indigenous peoples were "diagnosed" with endemic dysfunction that could be solved with therapeutic cures ranging from political apologies to legal compensation mechanisms.

I argue that the focus on individual harms experienced by Indigenous peoples has detracted from an analysis of perpetration. Furthermore, even when perpetration is publicly discussed, it is tempered with the politics of atonement and apology to soften the consequences of historical injustices and to obscure ongoing oppression. By reflecting on the dynamics between reparations, Indigenous harm and apology, I question whether or not reparations ensure the settler state's accountability. My next chapter examines how investment strategies and rationale are used to contain the amount of reparations provided to Indigenous peoples, and look at the extent of the settler state's responsibility in perpetrating crimes and responding to contemporary demands for social justice. 


\section{Chapter 3: Accounting for Justice: The Indian Residential Schools Settlement Agreement}

We need to continue to convince the public about the need to settle these cases and that it must not be seen as throwing money at Aboriginals [sic]. We have to do a better job of explaining the real impact of residential schools and the need to take responsibility for what took place (DIAND 2000, 97).

There is a hard lesson that has come to me over 35 years as a lawyer, a politician and a banker: 'You don't get what you deserve. You get what you negotiate' (Jim Prentice, CIBC Keynote Speaker at $34^{\text {th }}$ Assembly of First Nations Annual General Assembly July 2013, 4).

In 2004, the Assembly of First Nations released a report that demonstrated a need for just reparations to be provided to former students of the residential school system. The conclusion of this report suggested that a holistic compensatory framework should be considered

a long-term investment for the country, the people of Canada and for the well-being of First Nations. If value is put on reconciliation and healing past harms, it will certainly result in a proposal being a cost effective one. Statistically, healthy communities are self-sufficient and economically viable ones, resulting in further cost savings. (AFN 2004, 40 emphasis mine)

The investment discourse that is used to frame reparations here constructs an ostensible "we" of nationhood that envisions reconciliation as a shared process of accountability and healing. The benefits of this process are figured to be economical and profitable for both Indigenous peoples and settler-Canadians.

Four years after this report was released, and just hours before the 2008 National Apology to former residential school students was given by then Prime Minister Stephen Harper, Conservative MP Pierre Poilievre was heard on a local Ottawa radio show questioning the integrity of the Indian Residential Schools Settlement Agreement's reparative mechanisms. He stated: "Now, some of us are starting to ask are we really getting value for all of this money and if more money is really going to solve the problem. My view is that we need to engender the values of hard work, independence, and self-reliance. That's the solution in the long run, more money will not solve it" (Wherry 2008, n. pag., emphasis mine). In establishing a link between reconciliation initiatives and their economic "value" to the settler state, Poilievre underscores an expectation of 
financial return on behalf of the settler state. MacLean's columnist Aaron Wherry (2008) suggested that Poilievre's statement revealed a belief "that compensation for the victims of physical and sexual abuse should be treated as investment. A full accounting required. A proper return demanded" (n. pag.). For Poilievre, the Indian Residential Schools Settlement Agreement represents an investment that is only viable to the settler state if former students use reparations money to, in other words, "pull up themselves up by their bootstraps" in an effort to safeguard the nation-state's health and prosperity. Documenting the history of redress processes I ask, how might reparations that were at first designed to be accountable to former residential school students risk becoming a tool of settler and neoliberal governance?

To understand how reparations may be transformed through application and receipt processes, I situate the concept of accountability within my conceptualization of investment rationale. According to Diane Nelson (2010), "accountability includes recognizing and apologizing for foul play as well as paying to repair the effects of these actions in a sort of monetary and moral ledger where finance as wealth is joined to settling accounts, to a balancing out" (89). She goes on to note that "reparations have been demanded as a duty, an obligation of the state to acknowledge its actions and make amends. They are not a gift or a calculated investment, but a morally binding responsibility" (Nelson 2010, 90). In this quote, Nelson places accountability above the cost of reparations, citing a moral responsibility of the perpetrator to address the debts created by historical injustice. However, her analysis does not readily address the tension between demands for accountability of both the victim and the taxpayer. This tension is most acutely felt during the neoliberal era (see also Henderson 2012; James 2006; 2013).

I revisit the Royal Commission's astute assertion that: “Governments are reassessing their role in society and cutting back public spending. It would be a travesty of justice, however, if 
concerted and effective action to rectify the results of a history of dispossession were abandoned on grounds of fiscal restraint. A great debt is owing, and Canadians cannot, in good conscience, default on it" (People to People 1996, n. pag.). While RCAP also addresses the moral obligation required to account for historical violence, the Commissioners point out the threat to the distribution of reparations that is posed by austerity measures and cost-saving strategies. I identify a tension that exists between the settler state's accountability to reparation claimants and to the Canadian taxpayer, and in doing so, interrogate how reparations designed to repair and compensate victims of historical injustice have become strategies to contain and discipline reparations and to situate healing as an access point to neoliberal citizenship within the settler nation (see also Million 2013).

To document how investment rationale shapes the reparations process, I trace the myriad ways that reparations strategies have been used to contain settler accountability for historical injustice and to engender Indigenous accountability for the receipt of reparations. Firstly, I examine how a politics of "doubt" was enacted against Indigenous claimants during the statesponsored Alternative Dispute Resolution process to ensure that both reparation amounts and state culpability were reduced. Secondly, I examine how the politics of financial "settlement" is used to contain culpability and restrict the claimant eligibility through stipulations enforced by the narrow parameters of class action lawsuits. Thirdly, in documenting the politics of restorative justice, I also observe how strategies of containment work in tandem with disciplinary strategies that emerge when reparations are deployed through the Indian Residential Schools Settlement Agreement.

The Politics of Doubt and the Alternative Dispute Resolution Mechanism 
As I outlined in the previous chapter, the government of Canada established an Alternative Dispute Resolution Mechanism to provide reparations to former students of the residential school system. This pseudo-judicial mechanism was enacted through a state-sponsored process designed to respond to an overflow of lawsuits that were flooding the court system during the late $90 \mathrm{~s}$. In 2000 , there were 5,800 individual lawsuits in the court system and seven class action lawsuits against the government and the churches (McGrath 2000,2). Many scholars have argued that the implementation of the Alternative Dispute Resolution Mechanism was an attempt by both the government and the churches to minimize the costs of legal battles and share the cost of reparations (Blackburn 2012; Farrow 2014; Henderson and Wakeham 2009; Funk-Unrau and Synder 2007; McGrath 2000; Moran 2014; Roach 2014). An Alternative Dispute Resolution Mechanism was heralded as beneficial to claimants because it is a victim-centered and informal adjudication process (McGrath 2000; Law Commission 1998); however, once implemented, this approach was critiqued for neglecting to prosecute perpetrators, underplaying public acknowledgement of historical injustice, and providing smaller reparations packages for claimants that would be afforded by the courts (see also Henderson and Wakeham 2009).

In a paper penned for the Canadian Forum of Civil Justice, Carla McGrath (2000, 4-5) outlined the substantive and emotional "interests" of the victims, state and churches that would be satisfied by implementing an Alternative Dispute Resolution (ADR) Mechanism. She theorizes that victims would benefit from participating in an ADR process because substantively they would be faced with fewer costs, which would lead to "financial security" and "empowerment" (McGrath 2000, 4); the Government of Canada and churches would be able to "avoid court action wherever possible," leading to the minimization of costs for the state and financial security for the churches (McGrath 2000, 4-5). The emotional and psychological counterpart to the cost-saving mechanism 
was psychological/emotional "closure" for the state and "spiritual healing" for the churches (McGrath 2000, 4-5). I gloss this catalogue of substantive and emotional interests to demonstrate how financial and "emotional" forms of accounting are used to produce an inventory of "returns" for the various participants in order to justify the importance of reparations.

The Alternative Dispute Resolution Mechanism was officially implemented in 2002 but was cancelled within a year of its implementation, most notably because there was a scarcity of successfully awarded claims and a surplus of well-documented complaints about antagonistic and adversarial treatment experienced by claimants during the adjudication process. The narrow parameters of the process ensured that of the 87,000 former residential school students who were identified by government officials identified through pilot project research, only 13,500 claimants were deemed eligible for compensation by the ADR adjudicators, and of this pool of candidates, only 7\% actually applied (Funk-Unrau 2007, 299). The ADR process required claimants to fill out a 40 page document that asked them to convey detailed information about the abuses and harms they suffered as children in the residential schools. These forms were then submitted to unknown government officials who analyzed the legitimacy and extent of the abuse experienced by each claimant. Following the submission of the form, Indigenous claimants were required to take part in an adjudicative process where they were required to hire legal counsel at their own expense. ${ }^{50}$ In this section I ask: does foregrounding "harm" instead of accountability during the Alternative Dispute Resolution Mechanism function as a cost-saving mechanism?

\footnotetext{
${ }^{50}$ The Alternative Dispute Resolution program then empowered adjudicators to employ an economic calculus that balanced loss with reparative payments. I will speak more about the quantification of loss and suffering in the following chapter.
} 
While the process was designed to acknowledge claimant harm, only the experiences of physical and sexual abuse were foregrounded. The acknowledgement of systemic assimilative practices that inflicted the loss of culture, status, language as well as family and community estrangement were curtailed by the rigid structure of the tort model. While the experiences of assault were presented as more egregious than other experiences related to removal, claimants were still subjected to extensive interrogation and investigations in order to "test" the veracity of their claims (see Assembly of First Nations 2004; Funk-Unrau and Snyder 2007). The tort model functions under causation principles that

limit the ability of the Canadian legal system to recognize and respond to the harms of residential schools. They have the effect of limiting an appreciation of the collective harms of the schools to all Aboriginal people and the collective responsibility of Canadian society for those harms. Causation requirements produce a situation where Canadian tort and criminal law blames Aboriginal people for conduct and conditions that can reasonably be attributed to the residential school experience. (Roach 2014, 571)

This reliance on causation principles led to the intensive interrogation and investigation of Indigenous claimants by both the church and the state. Funk-Unrau and Snyder (2007) note that "investigation adds one more controversial element to the process: the requirement that the claim can be proven and tested before it is officially valid. Even more demeaning for claimants is the realization that the federal government is prepared to pay private investigators up to three to four times what the claim is worth in the attempt to test its validity or discredit it" (293; see also Assembly of First Nations Report 2004). These investigations not only served to absolve the state's culpability in the abuse of former students, but also underpinned discriminatory assumptions that poverty and dysfunction is an endemic condition on Indigenous reserves instead of a consequence of political violence. Investigations were very costly and, arguably, conducted at the expense of both claimant and taxpayer. One could argue that investment rationale employed through the tort 
model led to the sacrifice of fiscal costs in order to ensure that the settler state's culpability was minimized.

Fiscal costs could also be recouped through the Government of Canada's defense of residential schooling by using crumbling skull logic. ${ }^{51}$ Crumbling skull arguments were used by the settler state to imply that "a plaintiff is said to have a preexisting condition that makes it likely he or she would have suffered the injuries for which damages are being claimed, independent of the tortfeasor's actions" (Blackburn 2012, 298). As I noted in Chapter Two, the tort model is deployed to compensate for harms experienced as a result of a crime committed by a tortfeasor (perpetrator); hence, awards are designed to place the claimant in their "original" position before they experienced the harm. It is in the definition of this "original" position that settler state accountability easily slips into legal murkiness (see Roach 2014). This argument supports prevailing assumptions that Indigenous peoples were in an equally dire position in their communities and in residential schools, and functions to "blame the present difficulties faced by the survivors on the survivors themselves, or perhaps worse still, on their often deceased parents" (Roach 2014, 593). These assumptions persisted in the public sphere beyond the ADR, as illustrated in a Globe and Mail article by Conservative pundit Margaret Wente (2008), who suggests that the "dominant" narrative of residential schooling "inflicts a legacy of dysfunction down through the generations. Even the grandchildren of survivors [sic] trace their problems back to the schools" (n.pag.). She then blithely characterizes residential schools as the "original trauma" for Indigenous peoples and laments that "[i]t is unacceptable to introduce another truth, which is that some children escaped even worse abuse at home, as well as tuberculosis, lice, malnutrition,

\footnotetext{
${ }^{51}$ A similar critique of the IRSSA's compensation process was advanced by church officials who suggested that the provision of reparations created a false dichotomy, where Indigenous communities were constructed as "idyllic" instead of sites of familial and community dysfunction, in opposition to which residential schooling was conceived of as a reprieve (see Niezen 2013).
} 
desperate poverty, and illiteracy" (Wente 2008, n. pag.). As Blackburn points out, the crumbling skull logic was deployed to reify assumptions about Indigenous dysfunction, while Roach suggests that it was employed to reduce the amount of reparations paid to also reinforce the myth of benevolence that was used to bolster the settler project. For these reasons, Paulette Regan's (2010) assertion that the Alternative Dispute Resolution Mechanism constitutes a form of "re-gifting" has significant merit (111-142).

In 2004, the Assembly of First Nations held a conference at the University of Calgary to discuss the shortcomings of the Alternative Dispute Resolution Mechanism and to brainstorm next steps in the demands for former residential students' redress. The Assembly of First Nations' Report on Canada's Dispute Resolution Plan to Compensate for Abuses in Indian Residential Schools (2004) disparaged the ADR mechanism and insisted on the implementation of a restorative justice model. While the politics of doubt and the inability to publicly address settler accountability through this process were prominent critiques cited by the AFN, the motivation for implementing a restorative justice model was the exorbitant cost of the Alternative Dispute Resolution process. In proposing an alternative redress process, the Report (2004) stated that "[t]he savings in administration, legal fees, litigation, delay and court costs should significantly if not totally, offset the increased compensation costs. When a value is put on reconciliation and healing past harms it clearly results in our proposal being a cost-effective one" (6). Cost-effectiveness is linked to accountability and justice because "a much larger percentage of available monies would go directly to Survivors or their estates and less to the administration and costs of litigation" (AFN 2004, 6). According to the Assembly of First Nations Report, financial accountability to claimants was a significant component of receiving reparations. Yet, even while being held accountable to 
Indigenous claimants, settler state culpability and the extent to which systemic problems are acknowledged through the law remain outstanding.

I argue that the tort framework was used to accomplish two things: to contain the parameters and payment of reparations and to contain state accountability. Both of these strategies led to the denial of justice for Indigenous claimants and encouraged former students to launch of a class action lawsuit against the federal government and the churches in order to pursue greater financial and moral accountability for both claimants and the Canadian taxpayer. In short, I suggest that the politics of doubt is bolstered by the politics of cost in order to offset settler accountability in a state-sponsored reparations program. The failure of this state-sponsored program to provide substantive reparations were publicly circulated, and former students of the residential schools, decided to try their luck in the court system.

\section{Taking Action: The Politics of Settlement and Containment}

As more and more legal challenges to the Canadian state over rights are forced into compromise, Indigenous peoples must wrestle with the prospects of seeking redress and justice through the legal system. Anti-colonial scholars and critical Canadianists view the law as a mechanism to manage populations and to maintain colonial authority (Blackburn 2012; Corntassel 2009; Mackey 2014; Razack 2002; Thobani 2007). Nonetheless, Indigenous peoples in Canada have received a modicum of success in legal battles, thereby initiating some political and attitudinal change amongst settler governments (see Tomiak 2011). Jacqueline Lasky (2011) notes that "many peoples and groups seek redress through the 'system'...," and in the process they run the risk of "inadvertently re-inscribing themselves as subjects of these oppressive systems" (22 author emphasis). Lasky's point is particularly valid in the case of redress and residential schooling. In this section I examine whether administering reparations through the same institution 
that inflicted the original harm can produce justice. This is a particularly poignant point to explore given the numerous class action lawsuits that were launched against the government and the four major churches who administered the residential school system. These lawsuits coincided with a series of criminal cases that were launched against former employees and administrators of these schools who were accused of sexual abuse and physical violence.

Class action lawsuits are normally recommended to claimants by legal practitioners for three reasons: "a) to render small claims feasible (putting numerous claims together and aggregating all the small claims into a large enough group to attract a lawyer willing to take a fee from a class action award); b) to save on the cost of duplicative litigation (in mass torts or mass accident cases); c) to make it possible for claimants to pool litigation resources and achieve economies of scale like those available to defendants" (Clark 2000, 188). Building on the conceptualization of cost, I demonstrate how class action lawsuits are designed to minimize cost and achieve greater reparations for those who may be economically marginalized. These definitions present class action lawsuits as a way to economically democratize the expression of public grievance. Yet, given that many class action lawsuits are resolved through settlement as opposed to legal wins, reparations are not awarded, but negotiated.

The consolidation and settlement of the IRSSA emerged from the rulings in two famous cases; namely, Cloud v. Canada which was launched in 1996, and Baxter vs. Canada which was launched in $2000 .{ }^{52}$ Prior to these two cases, Blackwater v. Plint was launched against the Government of Canada and the United Church of Canada by 27 former residents of the Port Alberni Indian Residential School. It was argued that the defendants should be liable for the

\footnotetext{
52 Thielen-Wilson (2011) states that "the certification of Baxter was conditional upon the acceptance of the IRSSA, which means that had the IRSSA not been endorsed, Baxter would need to return to the phase of applying for certification" (233).
} 
corporal punishment and sexual abuse that was inflicted upon former students. At the case's conclusion, liability was shared between Canada and the United Church (75/25) and the lead claimant in the case received $\$ 200,000.00$ in compensation. The Cloud class action lawsuit was filed in 1998 by formers students who attended the Indian Mohawk School in Ontario, and while they failed to obtain class certification at this time (and again in 2001), the claimants finally received certification in 2004.

The courts recognized that the participants of these class action lawsuits represented a uniform group of individuals that shared similar experiences of harm, thereby constituting a "class." The significance of achieving class certification in the cases of Baxter and Cloud was the recognition of 80,000 claimants who experienced similar negative impacts on their lives. The Baxter lawsuit was launched through a consolidation of numerous residential school class actions. Failing to achieve certification in 2000 , their appeal for certification was in process during the government's appeal of the Cloud certification. The certification of Cloud was seen as a "significant victory," not only for their own claimants but for other lawsuits as well (see ThielenWilson 2012, 231-4). In May 2005, the Supreme Court of Canada rejected the Government's appeal "of both the Cloud certification and the Baxter application for certification" (ThielenWilson 2012, 232) and following this, "the government appointed retired Supreme Court Justice Frank Iacobucci as its Federal Representative to negotiate IRS resolution with Indigenous representatives and claimants" (Thielen-Wilson 2012, 232). Iacobucci would oversee the negotiation of reparations as well the implementation and appeal of these reparations process once the Indian Residential Schools Settlement Agreement was finalized.

Exponents of the Baxter vs. Canada class action suggested that previous class action settlements, such as Blackwater vs Plint and the Alternative Dispute Resolution Mechanism, had 
been too focussed on the individualization of pain and suffering which had been experienced at the hands of a "few bad apples." The Baxter class action, however, "points to a wider colonial policy and legislation which gave rise to IRS institutions, and claims that this policy and legislation is itself a violation of human rights, a form of genocide," and used the language of intergenerational abuses "in order to demonstrate that culture, language and family connection was 'lost' by an Indigenous collective (rather than just by individuals)" (Thielen-Wilson 2012, 233-4). This new choice of language in the Baxter $v$ Canada case provides meaningful acknowledgement of harms committed against a racialized collective, and thereby gestures towards larger systemic practices that result in harm enacted across time and space.

While certification of the Cloud class action was indeed a success, it is also important to point out that both the Baxter and Cloud class action lawsuits were not won but instead settled out of court by the government, church and former students. I underscore this point because the reparations process that emerged from this settlement were negotiated as opposed to awarded. The act of settlement was useful for state entities so as to offset further liability for the state in the wake of ongoing legal victories for Indigenous peoples. For instance, Courtney Jung (2009) notes that "the AFN sought twelve billion dollars in general damages, twelve billion dollars in special damages for negligence, breach of fiduciary, statutory, treaty and other common law duties, and twelve billion dollars in punitive damages" (8). According to the Aboriginal Affairs and Northern Development Canada, approximately 5 billion dollars in compensation and reparative monies have been paid out by the settler state and the Churches (Aboriginal Affairs 2016, n.pag.). This is a significant difference in the amount that was originally asked for by claimants. The politics of settlement are central to understanding how the state was able to use the legal system to contain the reparations that were provided to former students of the Indian Residential School system. 
Since the settlement of the class action lawsuit denied overt culpability for harms caused, the impetus to settle Baxter vs. Canada has been characterized as a strategy of containment used by state and church actors, in an attempt to curtail extensive damage to their reputations and pocket books (see Thielen-Wilson 2012, 249-52). The act of containment was particularly obvious in the process of class certification. For instance, residential schooling was part of a larger colonial policy that worked in tandem with acts of dispossession, violence and cultural assimilation. Yet, according to the parameters of class certification, only students who resided on the premises of residential schools were entitled to receive any reparations. In negotiating the Indian Residential School Settlement Agreement, claimant eligibility was defined through narrow parameters to ensure that the number of claimants (and therefore payouts) are kept to a minimum. The narrow parameters of the claimant categories left significant populations of former IRS students ineligible for reparations through the Indian Residential Schools Settlement Agreement. These limited parameters reveal accounting techniques used to limit the number of people who could apply for compensation and thereby transform the unknown amounts of compensation to be paid into a "knowable" number. The constraints of eligibility constructed as part of the Indian Residential School Settlement Agreement have been particularly divisive to First Nations, Métis and Inuit peoples throughout Canada, but have also had an impact on individual nations and communities as well.

The parameters of legal categories limit the number of eligible claimants that can participate in the restorative justice process. In the early 2000s, the Indian Residential School Resolution Canada and the Aboriginal Healing Foundation pooled energy and resources towards “counting Survivors" (AHF Vol. 2, 2006, 181). The Aboriginal Healing Foundation Final Report, Vo1. 2 notes that accurate calculations of former residential school students emerged from three 
main sources: Statistics Canada's Aboriginal Peoples' Survey (conducted in 1991 and 2001); The First Nations Regional Longitudinal Health Survey, which was conducted by the First Nations Centre of the National Aboriginal Health Organizations (NAHO) in 2002-3; and "a third data source" was taken from the Department of Indian Affairs in 1998 (182). According to the Aboriginal Healing Foundation (2006), the "cross-referencing from these three sources supports estimates of surviving residential school attendees and relatives of Survivors, but each source has limitations and overall number must be read with caution" (AHF Vol. 2 2006, 182). In 1998, the Department Indian Affairs and Northern Development had estimated that there were between 105,000 and 107,000 former students that were "still alive in 1991" and had "attended residential schools" (AHF 2006 Vol. 2, 182). Accounting for former students of the residential schools, the government was now able to make a reasonable estimate of the cost of reparations.

Despite the large numbers of Indigenous persons who had attended residential schools, many were excluded from the IRSSA due to the narrow eligibility criteria; namely, day school students, the Nunatsiavut Inuit, the Innu Nation and Métis peoples. The IRSSA primarily governs eligibility for compensation through certain criteria that includes residence at a school that appeared on the Official Schools list. ${ }^{53}$ This totalled approximately 135 different institutions which were administered in different timelines. Therefore, the eligibility of claimants in the IRSSA is primarily addressed through the claimant's residency at a residential school. A particular school receiving official status depended on the jurisdictional governance of the institution, in other words, the level of government from where the institution received its funding. ${ }^{54}$ Many Métis

\footnotetext{
53 The full list of Official Indian Residential Schools can be accessed by claimants through various online sources (see Independent Assessment Adjudication Secretariat 2011, 40-4)

${ }^{54}$ Since the negotiation of the Settlement Agreement "there have been 1447 requests to add IRS schools to the list of eligible schools under the Settlement Agreement. Thus far, the following schools have been added: St. Paul's Hostel, Dawson City, Yukon; Anahim Lake Dormitory, British Columbia; Cote Improved Federal Day School, Kamsack
} 
students ${ }^{55}$ educated in the Western provinces, or those students who attended schools in Nunatsiavut or Innu territory, were left out of the agreement because the institutions operating in these areas were administrated or funded by provincial entities and therefore did not fall under the jurisdiction of the federal government. Moreover, many Indigenous children experienced numerous forms of abuse at federally run day schools, but were not entitled to compensation because they did not reside on site. Similarly, while many schools appeared on the list, criticisms surrounding the neglect of Indian hospitals were also cited by Survivor organizations as a weakness of the eligibility criteria of the agreement. In response to these exclusions, Commissioner Sinclair of the TRC stated that

[t]he issue of day scholar exclusion, and exclusion of certain schools from the class action litigation, still remains to be discussed because I'm not sure it makes any sense for us to be looking at the possibility there may be another class action lawsuit, there may be another settlement agreement and there may be another truth and reconciliation process in the future. (quoted in Green 2012, 143)

Commissioner Sinclair frames the Indian Residential Schools Settlement Agreement as an inadequate reparations program because only some former students are recognized as legitimate. The Agreement only partially addresses a much more substantive policy of child removal, of which provincial governments and other religious organizations were administrators. While it can be argued that class eligibility increases the viability of a case's success in the courts, one could also suggest that restrictions on class distinctions are designed to limit the number of claimants.

The exclusion of Métis residential school students from the Indian Residential School Agreement has been publicly criticized by Métis National Council leader, Clem Chartier. A former

\footnotetext{
SK; Battleford's Industrial School; Fort George Hostels, Quebec; Wawanosh Home, Ontario; Stirland Lake, Ontario; Cristal lake, Ontario" (Special Chiefs Assembly 2012 c, 91-2.).

${ }^{55}$ Métis students contacted the Merchant Law Group, one of the lead counsels in the IRSSA, and asked to launch their own class action lawsuit in the Western provinces. This lawsuit was rejected in October 2013 (Narine 2013, n.pag.).
} 
residential school Survivor himself, Chartier claims that the experiences of many Métis children at these schools were not acknowledged due to a legal technicality (provincially operated schools) despite the fact that their experiences of violence and abuse were very similar to those of their First Nations and Inuit counterparts. According to President Chartier, "the hurt runs deep. As a people we have faced many challenges, but nothing has been more personal and hurtful than the lack of recognition for our people who attended Métis residential and day schools. It is a continuing struggle trying to convince the federal government to do the right thing for all Aboriginal peoples, including the Métis" (Métis National Council 2013, n. pag.). Former students from the Nunatsiavut region have experienced the rejection of their compensation claims because, much like Métis applicants, the majority of the schools in this region were provincially funded. Despite eventually securing their own class distinction through the Supreme Court in order to launch their own lawsuit against the federal government, ${ }^{56}$ there is great concern that shortages in health supports (that are afforded to claimants of the Indian Residential Schools Settlement Agreement) have not been extended to former students of Nunatsiavut schools.

This section identifies how legal procedures instigating "settlement" can be used to account for and contain the cost of reparations. The limitation of eligibility criteria is critical to analyzing the reach of reparations in Canada considering the extension of reparations to some Indigenous peoples and the denial of reparations to others. This undermines the original claim of Gathering Strength, which I discussed in Chapter Two, that claimed recompense would be extended to all Indigenous peoples who experienced harm. Once the Baxter and Cloud Class action lawsuits were

\footnotetext{
56 On January 18, 2012 Mary Simon, former President of Inuit Tapariit Kanatami reported on the following on her blog, "Just before Christmas the Newfoundland and Labrador Court of Appeal upheld a lower court ruling that approved the certification of a class action lawsuit involving former residential schools survivors in Labrador. The decision confirmed admissibility of claims against the Government of Canada respecting the operation of schools attended by Inuit (and Innu and Métis peoples) in Cartwright, Northwest River, St. Anthony, Nain, and Makkovik" (Simon 2012 n. pag.; see also CBC News 2011).
} 
settled, Indigenous peoples and legal practitioners agreed that restorative and reparative models of justice should be used to structure the IRSSA. This multi-pronged approach to redress included different forms of reparation such as compensation, health supports, commemoration monies and a Truth and Reconciliation Commission. Renewed hope in the benefits of restorative justice blossomed with the prospect of enacting reparations.

\section{Restoring Stakeholders}

To avoid the reproduction of unjust power relations, former students (under the guidance of the Assembly of First Nations) insisted that reparations should be negotiated through a restorative model of justice. Restorative justice is defined by Woolford and Ratnor (2007) as an informal approach to justice that differs significantly from formalized trial-based approaches, in that these processes promote inclusivity of multiple "stakeholders" and an emphasis on victimcentred approaches to realizing justice. Indigenous claimants favoured restorative justice processes because these models are said to democratize an otherwise hierarchical legal system (Braithwaite 2002; Woolford and Ratnor 2007). The democratic aspect of restorative justice has been questioned by many Indigenous participants and by the National Residential School Survivor Society. ${ }^{57}$ Below, I argue that the restorative model utilized in the context of the Indian Residential School Settlement Agreement requires further decolonization because this form of justice does not account for inequitable power structures present within Canadian legal institutions, address histories of violence imposed as a result of racialization, or respond to demands for restitution in the form of extensive capital and land transfers (see Alfred 2009 a).

\footnotetext{
${ }^{57}$ At the outset of the Agreement's implementation, the National Residential School Survivor Society analyzed the IRSSA and deduced that "Survivors do not have direct input to the composition or administration of the Settlement Agreement" because the "Assembly of First Nations, the Inuit Representatives, and Church and legal entities retain control" (NRSSS 2007, 5) of the various processes and committees. This lack of Survivor input in the compensation process re-affirms institutional and state power, often relegating former students to mere recipients of compensation as opposed to participants in the implementation of reparations.
} 
According to Jennifer Llewellyn (2008), a consultant and architect of the Indian Residential

School Settlement Agreement, restorative justice

is a theory of justice that sees justice as concerned with the harms to people and relationships resulting from wrongdoing. Justice on a restorative account requires the restoration of relationships harmed. Starting from a relational worldview, restorative justice recognizes the fundamental interconnectedness of people through webs of social relationships. (188)

Restorative justice models are designed through direct consultation with all participants, and therefore ensure that victims have a stake in deciding how harms are recognized and how redress and restitution are constructed. Pat O'Malley $(2006,224)$ points out that restorative justice models' focus on harm instead of offence helps to formulate a victim-centred approach to justice. Placing the victim at the center of the process does not guarantee the disruption of the inequitable power relations and may in fact place undue scrutiny on the victims of the process. In the 1990s, critical legal scholars noted that informal processes such as mediation are complicit in exacerbating existing hierarchies of power based on gender and race that exit in broader society (see Grillo 1997; Delgado 1997). Under certain circumstances (such as the perpetration of sexual violence), informal justice is considered unproductive and damaging because reconciling (or even meeting) with the perpetrator is an unjust and harmful request (see Deer 2004; Million 2013). Therefore, in the case of residential schooling, it is not enough for restorative justice to be "victim-centred": this model of justice requires further decolonization because the scrutiny placed on victims (and their suffering) may actually undermine the agency and authority of Indigenous peoples in determining just outcomes for communities. Restorative processes are said to "empower" victims "to deal with their problems responsibly" (O'Malley 2006, 225), but the emphasis on individual victimization may obscure the perpetration of violence by large entities such as the settler state. The atomization 
of harm and victimization coincides with neoliberal values that support the notion that citizens should act as individual entrepreneurs, even in their attempts to seek justice from the state.

The restorative model of justice was also chosen as a popular reparative framework because it is commonly associated with the practice of Indigenous law (see Assembly of First Nations 2004; Petroukov 2011; Woolford 2003). Despite the methodological similarities between the restorative justice and Indigenous justice models, the two approaches should not be conflated. Emma LaRoque $(1997,86)$ has also noted that when Indigenous models of justice are utilized in Canada, they are implemented alongside an Indian Act system that fundamentally curtails Indigenous legal jurisdiction. Taken out of their original context, Indigenous legal models are often subject to juridical cherry-picking in order to emphasize "social harmony," often the expense of victim's rights (LaRoque 1997, 81). Instead, LaRocque suggests that Indigenous models of law need to be researched thoroughly and implemented in their entirety to ensure that community values are not diluted or compromised within the context of settler law and legal institutions.

As I will discuss in further detail in Chapter Five, I assert that the restorative model endorsed relationship-building instead of decolonization as a primary goal. The emphasis on relationships is an important feature of both settler and neoliberal governmentalities because inequitable power relations are obscured by a narrative of harmony (see Amagoalik 2012). Narratives of amicable relations bolster investment rationale because a "good" investment creates mutual beneficiaries. The desire for advantageous relationships has led some critics to suggest that reparations have led to premature legal settlements (see Henderson and Wakeham 2009; Green 2012). For instance, Rupert Ross (2006) notes that

[t]he problem with many restorative justice processes as they are operated is that they seem to focus primarily on achieving that agreement. Some programs even train their conference facilitators in mediation, a process designed to settle business disputes, where most issues 
can ultimately be reduced to money and where "values" and "personal relations" are seen as somehow getting in the way of achieving "win-win" agreements. (xvi)

Establishing a "win-win" agreement in the context of residential schools does not account for the massive material and affective damage that former students experienced when forced to negotiate with the perpetrator. Moreover, if both parties are supposed to benefit from negotiating reparations, it is important to consider what kinds of veritable strings are attached to compensatory monies. Moten and Harney (2012) note this caveat in their analysis of restorative justice: "[r]estored credit is restored justice and restorative justice is always the renewed reign of credit, a reign of terror, a hail of obligations to be met, measured, dispensed, endured" (n. pag.). These scholars present restorative justice as practice that demands specific behaviours after money has been exchanged to signify justice being served. If an investment rationale governs the provision of reparations, then Indigenous peoples are required to behave accordingly once reparations are provided. Taking the settler state's ability to determine reparative outcomes into account, I argue that restorative justice functions an example of affirmative repair. As Woolford asserts, affirmative repair

is used as a subtle means of force through which a dominant group places assimilative pressures on a less powerful group. In the modern context, this typically involves enrolling the group into the project of neoliberal governance to an extent that it becomes difficult for the group to assert its difference in any way contrary to the prevailing political and economic norms of local and global markets. (Woolford 2004, 429-30)

A restorative model focused too much on restoring relationships and addressing "suffering," instead of instituting structural change, denies the restitution of land and the redistribution of resources that would be necessary for the implementation of decolonized forms of justice.

\section{The Indian Residential Schools Settlement Agreement}

The Indian Residential School Settlement Agreement was finally settled in November, 2005, to replace the failed state-sponsored Alternative Dispute Resolution Mechanism. As I have 
argued in the previous section, accounting and restorative justice practices have been adopted in order to ensure accountability to former residential school students, but these mechanisms have also been used for traditional economic ends, helping to ensure cost-effectiveness and the containment of reparations. The Indian Residential School Settlement Agreement was eventually formed through negotiation with a series of stakeholders that in included the Assembly of First Nations, the Inuit Tapariit Kantami, the Catholic Entities, The Presbyterian Church of Canada, the Anglican Church of Canada and the Government of Canada. Together these legal representatives negotiated the multi-pronged agreement which afforded reparations to former students of the residential school system.

I argue that the implications of reaching financial settlement in the context of the Indian Residential School Settlement Agreement are a) to limit the number of claimants, b) to ensure Survivor transparency once claimants apply for reparations monies, and c) to account for how reparations monies are spent. The complexity and diversity of the IRSSA's components demonstrate a commitment by government officials, Indigenous peoples and legal professionals to provide some semblance of accountability to Indigenous claimants. Nonetheless, the pervasive influence of neoliberalism and investment rationale has subjected Indigenous claimants to exclusionary practices that undermine the reconciliatory spirit of the reparations that are received. The provision of reparations requires the settler state to assume the acceptance of risk, but the demands for transparency and financial literacy from Indigenous claimants demonstrate the extent to which investment rationale underlies the Agreement. The following sections outline the reparations afforded by the Indian Residential Schools Settlement Agreement and identify the ways in which they have been influenced by accounting practices and investment rationale.

\section{Common Experience Payment}


Based on the criticisms of the Alternative Dispute Resolution Mechanism, the Assembly of First Nations (2004) recommended that an ex gratia payment be made available to all former students who attended residential school. The Common Experience Payment compensated claimants based on the number of years an individual spent in a residential school. Therefore, it did not require the disclosure of experiences of sexual or physical abuse because receipt of payment was based entirely on the length of one's residence in a federal institution. In 2005, the Canadian Bar Association released a report entitled The Logical Next Step: Reconciliation Payments for all Residential School Survivors, which advised "a reconciliation payment would be restorative" and, therefore, "would not require a person to prove that he or she was a victim, but rather would recognize a person as a survivor of an injurious program for which the government of Canada is responsible" (4). Stated more clearly, the ex gratia payment took into account the difficulty of claimant disclosure during adjudication and demanded a compensation framework that responded specifically to the act of child removal. The payment also addresses that cultural and language loss as well as the dissolution of family and community ties were harms that were experienced by all those who attended residential schools. Each claimant would receive $\$ 10,000$ for the first year of attendance and $\$ 3,000$ for each additional year that they attended an official institution. The average payment made to an individual claimant amounted to approximately $\$ 20$, 458.00 (Aboriginal Affairs 2016, n.pag.). ${ }^{58}$ The Common Experience Payment sharply contrasted

\footnotetext{
58 The Common Experience Payment received 105, 530 applications to which 79, 302 claimants received payment and 23, 927 were rejected. In the event that applications are rejected, the Common Experience Payment allows for applicants to apply for reconsideration, appeal and court appeals. Reconsideration is conducted by government administrators, appeals are considered by the National Administration Committee, and the final court appeal is conducted by court officials. It is difficult to get a good sense of how many new applications were confirmed in the reconsideration or appeal process, because only single number statistics are provided and many appeals were filed by those who had already file successful claims but were missing certain years (Aboriginal Affairs 2016, n.pag.).
} 
the long and arduous investigations and cross-examinations required to receive compensation from the state-sponsored Alternative Dispute Resolution fund.

\section{Money?}

Where research has been conducted about the Common Experience Payment, it has focused on the impact of receiving reparations monies. For example, a study done by the Aboriginal Healing Foundation, entitled The Indian Residential Schools Settlement Agreement's Common Experience Payment and Healing: A Qualitative Study Exploring Impacts on Recipients, interviewed over 100 recipients of the Common Experience Payment. Investigators found that

a minority found the LSP [lump sum payment] process beneficial and positive, most saw it as financially inequitable and emotionally draining; however, once the monies arrived, many recipients turned their LSP into a positive financial opportunity to help out family, purchase needed items, clear up debts, and make investments. On the negative side, recipients noted that LSPs often led to troublesome increases in problems such as drug and alcohol abuse, pressure from family for money, and encroachment by financial predators. $(2010,6-7)$

The report eventually concluded that many former students saw little connection "between healing and money" (AHF 2010, 93) because the application process and receipt of money triggered negative emotions and memories from the past abuse and trauma. Siksika artist Adrian Stimson (2008) affirms these findings when he states:

I am not a supporter of the "Common Experience." I recognise that the process might be good for some. I suspect that, in the end, many will not realise its touted benefits. For instance, a physician on my reserve indicates that he has never seen things so bad, that the stress resulting from the reliving of these past experiences has brought about suicides, attempted suicides, depression, alcoholism/drug abuse and violence within the community. It is a new epidemic that furthers the destruction of a people. I am personally frustrated, angered and sad as I see the toll this process has taken on many people, including family and friends. While I understand the intention of the process - to bring closure and a forum in which to expose the horrific stories these schools produced - I cannot help but feel that a new wound is being inflicted. (n. pag.)

Stimson's description of compensation as a new wound or epidemic is particularly salient in this context because he emphasizes how the process of applying for compensation is itself particularly 
difficult for former students. Other claimants reported that they harboured feelings of guilt because family members had passed away before they had received their compensation (AHF 2010, 90), and others suggested that the narrow window to make CEP applications exerted unnecessary pressure on them to apply before they were ready to do so (Green 2012,140$).{ }^{59}$ Similarly, the bureaucratic mechanisms surrounding the process lack clarity and claimants had few places to turn to for support, resulting in repeated disclosures to strangers in impersonal contexts such as over the phone (Green 2012, 140).

\section{Suggested Spending}

The Common Experience payment has strict parameters on how surplus monies set aside can be spent. Any surplus monies would be used to support intergenerational benefits in the form of a "Personal credits" program. This program provided a non-monetary award that could be used solely for "educational purposes" by anyone who voluntarily applied for themselves, their children or grandchildren. As a proper education (and therefore potential employability) was denied to claimants, the ability to fund their children's education may have been compromised; therefore, all recipients of the CEP are eligible for the "personal credit" program. ${ }^{60}$ The Common Experience payment (believed to be the most sought after by former students) was endowed with a specific budget upon the settlement's construction which was set at 1.9 billion dollars (Indian Residential Schools Settlement Agreement 2006 d, 4). If there was a surplus in this fund that exceeded 40 million, the remaining funds could be disseminated amongst claimants as "education credits." The Personal Credits program constitutes a voluntary application to receive a non-monetary award. The

\footnotetext{
59 All CEP Applications were to be filed by September 19, 2011, with process opening up in 2006 . This gave claimants only a five year window to apply for recompense.

60 In September of 2012, Employment and Social Development Canada hired an external auditor to conduct an audit on the Common Experience Payment Designated Amount Fund and the final results were posted online in March 2013 (Aboriginal Affairs 2016, n.pag.).
} 
application forms were posted in January 2014 with an application deadline of October 2014. Any surplus funds remaining after the extension of personal credits program would be designated to two educational organizations that provide educational funding to Indigenous youths, the National Indian Brotherhood Trust Fund and the Inuvialuit Education Foundation (Indian Residential Schools Settlement Agreement 2006 d, 4). The CEP Designated fund began with $\$ 1,817,392,000$ and as of September 19, 2012, the last day to apply to the Common Experience payment, the fund had only used \$1, 525, 404, 000 (Aboriginal Affairs 2016, n. pag.). After administrative costs were factored in, approximately $\$ 300$ million dollars were dedicated to the Personal Credits Program (Aboriginal Affairs 2016, n. pag.).

The Personal Credits program demonstrated some promising criteria, ${ }^{61}$ but the imposition of certain requirements on compensation was met with some anger and frustration on behalf of IRSSA claimants. According to The Canadian Press, "the [personal credits] plan has raised the ire of many survivors, who've flooded an aboriginal advocacy group with upset telephone calls and condemned the disbursal plan at community gatherings and in online postings" (CBC May 18 2014, n. pag.). There was a feeling amongst recipients that compensation should be spent on whatever claimants chose to spend it on, instead of what the Agreement imposed on them. Matsuda (1987) states that "the assumption that a beneficiary will make inefficient use of an award is unfair. All suitable plaintiffs are subject to such temptations. To prevent waste, programs and

\footnotetext{
${ }^{61}$ While these personal credits were primarily to be directed at individuals attending post-secondary institutions, this process allowed for recipients to pool their credits for collective educational opportunities that: address harms from the Legacy of Indian Residential School, like training programs that restore First Nations or Métis languages, cultural education, and personal development; preserve and transmit First Nation or Métis knowledge and skills (cultural expression, traditional knowledge, medicinal knowledge and folklore) to future generations; promote and restore First Nations and Métis values, traditions, traditional family and governing structures; include elements of research and capacity building for communities; address special needs of segments of the population, including those of the elderly, youth and women; are based on a community holistic approach designed to address needs of individuals, families and communities (AFN 2015, 1-2).
} 
investment can accompany awards. Trusts or structured awards are available upon proof of incompetence. That the victims are unaware of the potential for abuse or are incapable of devising appropriate solutions is itself a racist argument" (387). Therefore, any restrictions on whether the money will be given to individual claimants or their children, and how this money can be used, presents problems to the reconciliatory framework. The inability for claimants to decide where their funding goes demonstrates their lack of agency in the process. The specter of paternalism rises once again in relation to the personal credit surplus, because the architects of the agreement predetermined that claimants are not allowed to choose where they may direct a portion of their restorative payment.

\section{Financial Literacy}

The narrow spending parameters imposed on the CEP payment is but one example of legal governmentality that operates through the Indian Residential Schools Settlement Agreement. A wider concern surrounding the extension of reparations payments was circulated in the government and voluntary sector. One of the gravest concerns about the distribution of compensation monies to Indigenous claimants was the negative impact it may have on Indigenous families and communities. At a Standing Parliamentary Committee meeting in March 2007, Deputy Minister Peter Harrison suggested:

People are wondering what will happen once that money comes into the communities. Indeed, the amount I referred to could have a significant impact. As I have said, we are discussing that. A number of committees are dealing with the issue. As well, there will be soon be a conference, in Winnipeg, and its theme will be the impact of that money in communities....many communities are located very far from financial institutions. Individuals will receive cheques, and we are wondering what they will do with these cheques, given that there is no banking system in the remote communities. We are therefore discussing with banks and financial institutions to see how we can assist the individuals who will be receiving those payments. (Standing Parliamentary Committee Proceedings 2007, 26) 
To alleviate the fears of government employees, a new program was established in 2007 by government officials, bank personnel and Survivor Societies who agreed on a framework that would provide a seminar to former IRS students on how to manage their compensation payments. This program was spearheaded by the Canadian Executive Service Organization (CESO), which is a "volunteer-based development organization" that specializes in "strategic planning, business development, accounting and finance, organizational development, community development, governance and production and operations." ${ }^{62}$ The initiative "paved the way for the development and delivery of a critical cross-Canada financial management training program for survivors of Residential Schools, family members and frontline workers following the financial agreement with the Canadian government" (CESO 2008, 6). Volunteers from the financial sector specializing in finance and business were invited to participate in regional events that included seminars for on personal reparations recipients finances, banking, investing, business entrepreneurship, frauds and scams, wills and estate (CESO 2007, 2). On their website, CESO cautioned CEP claimants that receipt of compensation may leave them vulnerable to elder abuse; however, what was surprisingly absent from their documentation on financial literacy was the way in which retailers and business were taking aim at settlement monies (see Beauchamp 2007; Friesen and O'Neill 2007). Instead of questioning the practices of a capitalist elite who would exploit Indigenous peoples, individual claimants were encouraged to "learn" how to manage their settlement monies in a safe and reasonable way. I argue that this approach reinforces beliefs that threats to settlement monies would come from within communities as opposed to from outside predators, a common belief that reinforces assumptions of endemic dysfunction within Indigenous communities.

\section{The Independent Assessment Process}

62 The vision of CESO is "Stronger Economies, Better Lives". 
The Common Experience Payment, or ex gratia payment, was implemented alongside a non-adversarial adjudication process, to be used in cases of extreme violation such as physical and sexual abuse, called the Independent Assessment Process. The Independent Assessment Process Guide suggests that "people who have suffered sexual abuse, serious physical abuse, or certain other wrongful acts which caused serious psychological consequences may receive money through the IAP" (IAP Guide 2011,3). The IAP represents what Erskine (2011) calls a "matrix settlement," which is a "distribution model" that is "designed to provide different levels of compensation to class members that have suffered varying degrees of damage of loss" (60). IAP Claims are processed through three different mechanisms: the Standard track ${ }^{63}$; Complex issues track ${ }^{64}$; and Court track, ${ }^{65}$ and claimants are directed through the process by the Independent Assessment Process Guide (available in hardcopy and online). The Independent Assessment Process was created "for former students who have a claim of sexual or serious physical abuse. It provides them with a way to settle their claim more quickly, out of court. The process is designed to be claimantcentered, but fair and neutral. It is an adjudication process. The Adjudicator resolves claims and awards compensation" (IRS Adjudication Secretariat 2013, n. pag.). The Adjudicator follows a set of categories and criteria that allow for the specific compensatory monies to be awarded.

The assessment framework for the Independent Assessment Process is very similar to the framework used in the Alternative Dispute Resolution Mechanism, however, long forms were

\footnotetext{
${ }^{63}$ This is the most common way to resolve IAP claims. Usually "the Secretariat deals with your claim at a hearing conducted by a neutral decision maker called an Adjudicator" (IAP Guide 2011, 5).

${ }^{64}$ This is used when "making a claim for actual income loss" or "making a claim that certain types of wrongful acts (other than sexual abuse or serious physical abuse, as defined) cause you serious psychological consequences" (IAP Guide 2011, 5)

${ }^{65}$ The Court Track implies "there is enough evidence that you lost more income or opportunity for income than the maximum compensation this IAP allows," or that "there is enough evidence that the physical harms you experienced were catastrophic and that the compensation available through the courts may be more than the maximum compensation this IAP allows. For example, such a physical harm could be a permanent significantly disabling physical injury"; or "in an 'other wrongful act claim,' the evidence involved in the harms you claim is so complex and extensive that going to the courts is the most appropriate procedure" (IAP Guide 2011, 5).
} 
simplified, and investigations were reduced so as to place the burden of proof on the individual claimant. The projected applications for the Independent Assessment process were approximately 12,500 cases, however, current figures suggest that 37, 997 applications have been made (Aboriginal Affairs 2016, no pag.). The most recent IAP update suggests that $89 \%$ of claims have been completed with an average payment of $\$ 112,496.00$ per claimant (Aboriginal Affairs 2016, no pag.). This process requires meetings with adjudicators and encourages the claimant to hire a lawyer (not necessary with the Common Experience Payment), and this has led to significant abuses of power by some legal practitioners. For instance, several law firms utilized the Independent Assessment Process to provide claimants with high interest loans, some upwards of $40 \%$ of their final settlement. Capitalizing on the financial desperation of claimants, law firms would provide claimants anticipated settlements but when settlements were won, large interest payments were taken from the actual settlement (Aboriginal Peoples' Television Network 2011, n. pag.). The IAP process is the subject of the next chapter, where I will examine its processes and participants in closer detail.

While the Indian Residential School Settlement Agreement was designed to create accountability to residential school former students, not unlike the case of the Alternative Dispute Resolution Mechanism, the administrators of the program were careful to ensure that Indigenous claims were "legitimate" and not "overblown." Despite implementing a more therapeutic approach to receiving reparations, the Independent Assessment Program still situated fraudulent claims as a major aspect of claims-making process. According to Michael Bay, an adjudicator of the Independent Assessment Process, part of the adjudicator's role in administering the claims process is protecting the economic interests of the settler state/taxpayer. He describes the arduous task of assessing genuine claims: 
What was necessary was a careful process that would do as much as humanly possible to weed out false claims and claims that did not meet the criteria to be established while at the same time, avoiding re-victimization of sometimes seriously damaged people. It was equally important to be sure that the government and the churches, indeed, the taxpayer, were protected from false claims and that the integrity of this process, and the legal system in general, be protected. Only legitimate claims should be allowed and the level of compensation paid should be legally appropriate. It was clear, right off the bat, that this was going to be challenging. Thousands of people had to be processed, had to be given the chance to tell their stories, in a manner that sorted the wheat from the chaff, respected the rights of all parties, and determined the truth while attempting not to harm the participants. A tall order, indeed. (Bay 2013, 6)

Bay's intervention could be read as a diligent commitment to his role as adjudicator, but the language used here also indicates a bias towards the protection of state interests as opposed to individual claimants. According to Michael Bay (2013), the adjudication process is extremely rigorous and requires extensive documentation of the claimant:

Long before every hearing, I receive hundreds and sometimes up to a thousand pages about the Claimant. I get a lifetime of health records, corrections records, employment and tax material, etc. And I receive another massive pile of paper about the school including architectural drawings and memos and materials and so on and so on, and there is extensive research as to the Claimant's attendance as well as the presence of alleged perpetrators. I spend a day or two absorbing this material before the hearing. I have a day set aside just to examine the claimant. (3)

Since former students of the residential school system have long struggled with the stigmatization of disclosure and the fear that their claims will not be believed in legal institutions, the emphasis on Survivor accountability in submitting abuse claims highlights suspicion towards Indigenous peoples experience of trauma and their right to compensation and could be indicative of a strategy for containment. Moreover, assumptions that Indigenous peoples may seek to exploit the legal system situates claimants as a cost to the nation-state. I observe a conflict of interest embedded within the Independent Assessment Process where the politics of doubt are employed to protect the settler state from being exploited by "false" claims.

\section{Therapeutic Health Supports}


The Aboriginal Healing Foundation was formed in response to recommendations from the Royal Commission on Aboriginal Peoples. As part of Gathering Strength: Canada's Aboriginal Action Plan (1998) the organization was "created to manage the distribution of a $\$ 350$ million onetime grant from the Government of Canada for community-based healing" (AHF Vol 1 2006, 1). The Foundation was designed to assist Aboriginal communities in setting up and administering healing programs in seven key areas such as: "direct healing activities, prevention and awareness activities, training activities, honouring history and building knowledge, needs assessment, conferences, project design and set up" (Graham and Mitchell 2009, 8). The first funding cycle of the Aboriginal Healing Foundation began in 1998 with a large contribution of 350 million from the federal government that was intended to fund the organization as well as community projects until 2004. The organization would receive another 40 million dollars in 2004 to extend funding of already existing programs for another two years. In 2004, the AFN Report (2004) on the Alternative Dispute Resolution program asked for a "commitment by the government" to ensure "adequate therapeutic resources for individuals and communities in recognition of the ongoing therapeutic needs through the activities of the Aboriginal Healing Foundation as well as through other means" (32). As part of the Indian Residential Schools Settlement Agreement, the AHF received 125 million dollars in funding to continue the support of healing programs for another 5 years. The funding replenishment in both cases only allowed the organization to continue funding projects that were already running, meaning that no new applications for funding programs were received after the contribution of the original endowment (see Spear 2014).

The Aboriginal Healing Foundation was governed by a board of 17 members which were representative of the major Aboriginal organizations (three for Assembly of First Nations, one for Inuit Tapiriit Kanatami, one for Métis National Council, one for Congress of Aboriginal People, 
one for Native Women's Association), government representatives (AANDC and Health Canada) and all regions of Canada. The first nine members appointed the remaining eight members, of which five were First Nations, one Inuk, one Métis and one was either Inuk or Métis. The Board of Directors is advised by an elder council made up of four members who have no voting rights. An elder from a First Nations, a Métis and an Inuit community are all invited to participate on the Board. A youth committee was also established to advise the board in their decisions. The Institute on Governance (IOG), a not-for-profit organization that designs and assesses best public sector governance practices, conducted an external review of the organization. The IOG found that the Board of Directors conducted and participated in regional meetings with service providers and communities (even those who had not received funding) in order to, a) share best practices and, b) lay foundations for creating networks between regional service providers (Graham and Mitchell 2010, 32). As a small organization, the representation of Indigenous peoples was a mandatory feature of the governing structure and nearly all board members were Indigenous peoples and included Indigenous communities that had been excluded from the Settlement Agreement.

Upon receiving a replenishment of funds from the Indian Residential School Settlement Agreement, the AHF was able to continue funding healing programs in constituencies that include "Inuit, Métis and First Nations, on and off reserve, regardless of whether they are registered under the Indian Act" (DeGagne 2008, 661). Once the organizations received monies form the IRSSA, they were able to continue 134 healing programs located in various regions all over Canada, and they continued to pursue a research agenda dedicated to examining the legacy of the residential school system. Despite the success and importance of the Aboriginal Healing Foundation's work, funding for the organization was cut in March 2010. Funding cuts resulted in the cancellation of the 134 healing programs a full three months before the first Truth and Reconciliation Commission 
National Event commenced. There has been some speculation that perhaps the Truth and Reconciliation Commission (TRC) was meant to replace Aboriginal Healing Foundation (AHF) programming, however, the mandate of the TRC was far more limited than the AHF, and resources to conduct healing projects and public education under the TRC mandate were minimal (see Chapter Five).

\section{Truth and Reconciliation Commission/Commemoration}

In addition to compensation, the Indian Residential School Settlement Agreement enacted provisions to establish the Truth and Reconciliation Commission of Canada, in order to obtain testimony from former students and to assemble a living archive of the IRS system to be used by researchers and the public. Schedule 'N,' otherwise known as the Truth and Reconciliation Commission mandate, states the following goals: a) to acknowledge residential school experiences, impacts and consequences; b) to provide a holistic, culturally appropriate and safe setting for surivors, their families and communities as they come forward to the Commission; c) to witness, support, promote and facilitate truth and reconciliation events at both national and community levels; d) to promote awareness and public education for Canadians about the IRS system and its impact; e) to identify sources and create as complete an historical record as possible of the IRS system and legacy. The record shall be preserved and made accessible to the public for future study and use; f) to produce and submit to the Parties of the Agreement a report of recommendations to the Government of Canada concerning the IRS system and experience including: the history, purpose, operation and supervision of the IRS system, the effect and consequences of IRS (including systemic harms, intergenerational consequences and the impact on human dignity of the residential schools); g) to support commemoration of former Indian Residential School students and their families in accordance with the Commemoration Policy 
Directive (Schedule J of the Agreement) (Indian Residential Schools Settlement Agreement, 2006 c 1-2). The TRC received 60 million dollars to conduct a five year mandate, which was extended for one more year by the government (March 2015) due to the extent of the institution's portfolio. Along with administering truth-telling processes, the Truth and Reconciliation Commission of Canada is responsible for administering 20 million dollars in commemoration funds to Indigenous communities in order to establish memorial projects in Indigenous communities.

The Truth and Reconciliation Commission currently had three Commissioners, Justice Murray Sinclair, Chief Wilton Littlechild and Marie Wilson, who attend national and community gatherings to witness testimony of former students. While the Commission was initially plagued with setbacks, ${ }^{66}$ with the induction of the three commissioners in 2009 the TRC has run relatively smoothly. The Truth and Reconciliation Commission offers two forms of statement gathering, public and private, and houses a demanding research mandate which includes specific projects, such as the Missing Children Project, ${ }^{67}$ and is required to provide an interim and a final report to the parties of the IRSSA.

\footnotetext{
${ }^{68}$ In October 2008, Justice Harry LaForme stepped down from his role as Commissioner citing an "incurable problem" resulting from irreconcilable differences between himself and the other Commissioners. Claudette Dumont-Smith and Jane Brewin Morley soon followed suit in January of 2009. LaForme also stated the Commission had a strained relationship with both the Assembly of First Nations and the Department of Indian and Northern Affairs. In a 2010 article in The Toronto Star, entitled "No Truth, No Reconciliation" Linda Deibel suggests that "the saga of truth and reconciliation is fraught with scandal, power struggles, firings, lost friendships and soul-destroying delays. The second and current set of commissioners, headquartered in Winnipeg, haven't even begun to hire critical staffhaving just finalized the recruitment process - and appear hobbled by federal procurement and hiring rules" (n.pag.). These lamentations against the delay of the reconciliation process, while true, still lend itself to "bad" victim motifs. There is little attention given to the reasons for resignations, such as the undue state intervention which LaForme repeatedly cited as his reason for departure. The shortcomings and deficiencies of the Commission in this context are actually an extension of colonial interference in what is understood to be an independent process led by Survivors and those who represent their interests.

${ }^{67}$ The object of this project is outlined here: "As part of its five year mandate, the TRC is required to prepare a report on the history and legacy of the IRS experience. One significant aspect of this history should include an examination of student deaths in, and disappearances from, the residential schools. Recent media reports describing the extent of the issue and the ongoing suffering it causes survivors and their families demonstrates the need for a thorough examination of what has come to be called the "Missing Children" issue. Research into Missing Children will work within the TRC's broader research plans and objectives, while still providing Canadians with a timely response to this highly sensitive issue (TRC 2012, 1).
} 
Under Schedule "N," the Commission hosts national events and community events so as to reach as many former students as possible. Seven national events were held in total over a five year mandate, and numerous community events are held to ensure that all former students are able to participate, preferably on their traditional territory (Indian Residential Schools Settlement Agreement 2006 c, n. pag). Each national event incorporates a unique schedule of programming that includes numerous activities, but focuses mostly on truth sharing panels with TRC Commissioners and members of the Survivor Advisory group. ${ }^{68}$ Reconciliation events include several education components, ${ }^{69}$ testimonial components, ${ }^{70}$ artistic components ${ }^{71}$ and

\footnotetext{
${ }^{68}$ According to the Concept Paper written for the Atlantic National Event, the Commissioners made the decision to incorporate all parts of the Mandate into National events. This includes: "Sharing and witnessing the Truth of survivors and their communities, and others affected by the school experience; Sharing Research findings about residential school history and impacts; Commemorating various aspects of this history; Educating the public; Supporting emotional and spiritual Healing a)through provision of contemporary and traditional health supports; $b$ ) through provision of cultural teachings and reflection; c) through traditional and contemporary musical celebration; Sharing and honouring examples of meaningful Reconciliation between and among various Parties to the residential school settlement agreement; Gathering materials for the eventual National Research Centre; a) through collection of written, spoken, audio-visual and other individual; and group "statements"; b) through documentation of all of the above" (TRC 2011 b, 3).

${ }^{69}$ In Winnipeg, a day long academic conference with papers delivered by scholars "from the West" was held, yielding often controversial responses from audience members. Many Indigenous participants pointed out that, while the research was interesting, there was much to be learned from Survivor testimony and that there was anxiety about having enough time to speak and tell their stories, while scholars (many of them white) were permitted an extensive forum. This criticism seemed to be taken into account when designing the Halifax event. Interactive workshops on a variety of topics were held for all participants. Topics included: Health and Healing, Indigenous legal systems etc. This interactive forum also assured that local organizations, Elders and practitioners were given the privilege of hosting these workshops. The workshops also permitted more informal conversation that relied less on Western theory or scholarly authority but ensured that Indigenous epistemologies and methodologies were privileged.

${ }^{70}$ The signature programming feature at National Truth and Reconciliation events are Commissioner's Sharing Circles, where Survivors are invited up to provide a public testimony to an audience. Also, popular sharing events include Dialogue on Resilience (Inuvik) and Dialogue on Reconciliation (Halifax). In Winnipeg, there were separate sharing panels for Indigenous women survivors and a panel dedicated to Intergenerational survivors and youth.

${ }^{71}$ Artistic components included plays and literary readings from Indigenous authors. At the Winnipeg National event, a literary reading night incorporated readings from Basil Johnston, Richard Van Camp, and Joseph Boyden. At the Halifax event an interpretive dance was conducted by a local dance troupe accompanied by the reading of Christy Jordan-Fenton's Fatty Legs. At each of the three events there were numerous film screenings, and in Halifax there was a room solely dedicated to film screenings (running films one after another). In fact, the greatest emotional outpouring and testimonial came one evening in Inuvik when two documentaries, "My Own Private Lower Post" by Duane Aucion and "Experimental Eskimos" by Barry Greenwald, were screened. Following the screening of Aucion's film, a woman approached the microphone. She did not address the filmmakers but instead turned around and faced the audience as she tearfully demanded that the Elders share their experiences with the youth. Following this, a gentleman came up to the microphone and asked filmmakers how he could talk to his children and tell them how
} 
entertainment. ${ }^{72}$ Truth and Reconciliation Commission events are based on the Seven Grandfather teachings (Ojibwe): respect, courage, love, truth, humility, honesty and wisdom. The Indian Residential Schools Settlement Agreement also extended 20 million dollars towards Commemoration projects. The vetting of these projects falls under the purview of the Truth and Reconciliation Commission.

Much analysis has been conducted about the limitations of the Truth and Reconciliation Commission's mandate. Specifically, prominent critiques relate to the lack of Indigenous consultation and a failure to incorporate Indigenous forms of truth-telling (see Corntassel 2009), the lack of perpetrator participation (see Regan 2010; Neizen 2013; Stanton 2011), the inability for testimony to affect substantive structural change (Blackburn 2006; Green 2012; Henderson and Wakeham 2009; Nagy 2012), and the Commission's general lack of resources (Auditor General 2013). The Truth and Reconciliation Commission of Canada is the subject of my analysis in Chapter Five, where I will examine the politics of partnership as a disciplinary concept and practice in regards to truth-telling.

In this section I have demonstrated how reparations enacted through a restorative justice model are not only used to contain and account for the number of reparations to be provided, but also to determine the outcomes of monies dedicated. The Common Experience Payment was enacted to ensure that Indigenous peoples spent certain compensation monies on education and financial literacy. Similarly, adjudicators from the Independent Assessment Process, while

he felt about his experiences. Commissioner Sinclair rose after this Survivor was done speaking and told him that he would make a copy of his speech so that he could show his children the tape.

${ }^{72}$ Many activities are included within this category, including a birthday party held for Survivors who were unable to celebrate their birthdays while attending Residential School. The churches were responsible for baking and distributing baked goods for Survivors. At the Montreal event, each person in the audience received a birthday card, a glow stick and a baked good. The lights were turned down and the birthday song was sung in each of the languages representing that territory. A favourite event of most attendees is the Talent Show, where former Survivors and intergenerational survivors are able to register for a gala concert and perform for all attendees. 
seeming preoccupied with protecting the interests of the state as well as the interests of claimants, demonstrated a conflict of interest. While the Independent Assessment Process was designed to be less intrusive than the ADR mechanism, the suspicion of fraud on the part of Indigenous claimants suggests that the politics of doubt are still at work in the newer process. Moreover, while health supports were extended to former students through Aboriginal Healing Foundation funds, they were soon subject to funding cuts after the introduction of the Truth and Reconciliation Commission. Indigenous peoples were routinely disciplined through the Indian Residential Schools Settlement Agreement, and Indigenous organizations were crippled by premature funding cuts and limited mandates.

\section{Conclusion}

In this chapter, I have examined historical and contemporary approaches to providing compensation to former students of the residential schools. In my Introduction I noted that the concept of investment was specifically dedicated to the practice of containment. Exploring reparations processes, I have demonstrated how investment rationale is operationalized through the Alternative Dispute Resolution Mechanism by way of a politics of doubt when it comes to questioning and "testing" the veracity of Indigenous peoples' claims. Despite the extensive documentation of the abuse experienced by former students of the residential schools in academic literature and Royal Commission testimonies, individual claims were subject to investigation and cross-examination to ensure that reparations amounts were minimized. Following the launch of the certification of the Baxter v. Canada class action lawsuit the politics of settlement were then operationalized by the settler state, who agreed to pay reparations without having to admit any wrongdoing. Moreover, the harms committed were viewed as acts of individual victimization and perpetration as opposed to being a part of a systemic program designed to destroy Indigenous 
culture by assimilating individuals. In both cases, the politics of doubt and settlement were employed to save the government money and, in the process, erode possibilities for redistributive structural change because the residential school system was treated as an anomaly. Lastly, a restorative model was employed to ensure that victim harms were centralized during the reparations process, but this model emphasized the creation of mutual beneficiaries that allowed the IRSSA to sustain returns on reparations for the settler state.

These three sections have documented how the tension between the state's accountability to claimants and to the citizen-taxpayer is manifested through considerations of temporal, financial and emotional costs. While the Alternative Dispute Resolution Mechanism seemingly invested in cost-saving strategies, the restorative model was able to determine particular reconciliatory outcomes to ensure individual claimants adhered to neoliberal principles such as healing at their own expense, increasing educational outcomes and managing/investing monies wisely. The consolidation of the settler and neoliberal projects is thereby facilitated instead of mitigated by settler law in the case of reparations.

While the law is often viewed by many non-Indigenous citizens as a neutral and unbiased tool that enables the pursuit of justice and redress, I assert that the law undoubtedly privileges the protection of the state and of non-Indigenous citizens. Building on this exploration of reparative compensation, in the next chapter I document how legal governmentality is manifested through the medicalization of reparative categories to encourage neoliberal performance amongst reparations recipients. 


\section{Chapter 4: Employing Trauma: Loss and Capital in the Independent Assessment Process}

There is an emerging and compelling desire to put the events of the past behind us so that we can work towards a stronger and healthier future (TRC Mandate quoted in Jung 2009, 13).

For far too long, many Aboriginal peoples have been left out of the mainstream of Canada's prosperity ("Introduction" Kelowna Accord: Strengthening the Relationship 2004, 4).

The Assembly of First Nations Report on the Alternative Dispute Resolution Mechanism (2004) states that a just compensation process for former students should be designed to "recognize that people were harmed, provide solace for their injuries, assist in repairing the emotional, physical and psychological damage caused by residential schools, and provide funds for the reconstruction of survivor's lives (18). This document suggests that the affirmation of loss and the provision of restitution were viewed by Indigenous peoples as essential components to compensating the experiences of residential schooling. However, as I noted in the previous chapter, loss becomes monetized through adjudicative and legal processes, which leaves compensation vulnerable to economization under the guise of accountability. In "accounting" for justice in such a way, I argue that the monetization of suffering through compensation processes has wider ramifications for the public understanding of reconciliation and Indigenous-state relations.

For instance, Conservative pundit Frances Widdowson (2010) insists that the government should "provide high-quality services that are tailored to the special needs of the aboriginal [sic] population so they can enjoy the emotional satisfaction ('self-esteem') that comes from making a social contribution" (n. pag.). Widdowson encourages Indigenous peoples to boost their selfesteem by finding meaningful ways to participate in civil society and the wage economy. I underline Widdowson's conflation of self-esteem with the former student's ability to contribute to Canadian society because it reveals settler assumptions that resolving conflict between Indigenous 
peoples and settler Canada is tantamount to "equal" participation in the market and wage economy (see Henderson 2013, 64). To investigate the relationship between compensation, therapy and investment, this chapter examines the forms and processes required to make a compensation claim for the Independent Assessment Process (IAP). As I noted in Chapter Three, the IAP process was created to compensate for "serious" forms of physical and sexual abuse experienced by individual students. The following chapter explores if and how the conflation of categories such as abuse and loss of opportunity in the IAP framework bolsters a racialized class politics that remains embedded in Canadian society. To inform my field of analysis, I draw on insights from the political economy of health and critiques of the "medicalization thesis" to reveal how judicial constructions of trauma are concomitant with settler demands for neoliberal citizenship in the compensation framework. Therefore, in this chapter I ask the following questions: How does the correlation between trauma and unemployment in the Independent Assessment Process construct the subjectivity of Indigenous claimants? How does the disciplining of Indigenous claimants through these categories extend beyond the compensation process?

This chapter examines how reparation monies function as a therapeutic investment for the settler state because compensation is imbued with a set of assumptions that presume that Indigenous peoples need to assimilate to mainstream Canadian society in order to "feel better." Firstly, I examine how therapeutic approaches to justice may adversely affect Indigenous claimants. Secondly, I examine the language of abuse and loss of opportunity in the Independent Assessment Process forms to explore how liberal values of individual economic freedom coincide with narratives of recovery from depression or suffering. Lastly, I interrogate the IAP category "loss of opportunity" as an indicator of how classifications of psychological harm remain fixed to a claimant's inability to work in the past or in the present. In doing so, I explore how the 
compensation framework contributes to an ongoing conflation of reconciliation and economic development.

\section{Therapeutic Jurisprudence}

This section examines the infusion of therapeutic discourses and practices within the Independent Assessment Process. As I argued in Chapter Two, the foregrounding of Indigenous suffering and trauma experienced by former students at the residential schools has helped to legitimize the need for reparations (see Aboriginal Healing Foundation 2008, 2009, 2010 see also Million 2013). Yet, Indigenous peoples' conceptualizations of trauma as a social phenomenon are routinely marginalized in favour of prevailing psychotherapeutic approaches. The latter approaches tend to conflate Indigeneity and dysfunction without providing the historical or structural context for the experience of trauma, focusing instead on individual symptomology and cure. Therefore, the construction of trauma and injury in the context of reparations is particularly contentious because, on one hand, the term has been useful in articulating the phenomenon of transgenerational suffering in Indigenous communities, but on the other hand, this terminology has linked Indigeneity with victimization (see Blackburn 2012; Million 2013) or membership in an underclass (Wotherspoon and Satzewich 2001). Therefore, the nature of Indigenous peoples' trauma is double-edged because while it is a viable concept used to articulate the devastating effects of colonization, trauma has also been taken up by settler and neoliberal projects in an effort to discredit Indigenous peoples’ demands (Blackburn 2012, 299).

Scholars and practitioners part ways over the influence of the therapeutic ethos on the provision of compensation through the Indian Residential Schools Settlement Agreement (IRSSA). For instance, Stephen Winter (2011) suggests that within the therapeutic perspective, "state wrongdoing is inadequately described as a pathological agent. The pathological metaphor 
obscures the claimant's political agency and an essential normative question-the immoral character of state wrongdoing. A state that injures its people does not merely harm its citizenry; it wrongs them" (804). Therefore, Winter $(2011,805)$ considers reparations as a response to a crime instead of a harm. For this reason, he has critiqued reconciliation initiatives derived from Gathering Strength (1998) such as Aboriginal Healing Foundation programming for relying too heavily on therapeutic approaches and goals (Winter 2011, 805). Instead, he suggests that the Indian Residential School Settlement Agreement, particularly the provision of the Common Experience Payment and the Independent Assessment Process, should diverge from therapeutic goals and embrace a corrective justice approach:

A legitimate state respects the rights of its citizens by avoiding wrongdoing. But if it fails in that effort, it remedies the damage. This remedy is in itself a respect for (remedial) rights. Therefore the practice of corrective redress goes some way towards meeting the juridical condition of legitimacy; the respect for individual rights. (805)

Therefore, the legitimacy of the state depends on the respectful treatment of its citizens and, if this is violated, the state must address the wrongs committed. In repairing wrongs, the state once again regains its legitimacy. Moreover, he insists that the IRSSA "have brought large numbers of indigenous [sic] persons, not only as claimants, but also as administrators and volunteers" (Winter 2011, 807-8) in contact with settler-Canadians to create a "common historical experience" of reconciliation and therefore, implements a more robust approach to reparations than promised through psychotherapeutic approaches. What Winter fails to account for is the way in which corrective justice may be co-opted by a therapeutic ethos, especially in the context of residential school reparations.

Not unlike the Alternative Dispute Resolution Mechanism, claimants of the Independent Assessment Process are required to fill out a form detailing histories of abuse from residential schools and the present ramifications of this abuse. Upon submission of the form to the Indian 
Residential Schools Secretariat, former students are required to attend a hearing with an adjudicator in person and are encouraged to hire legal counsel. Therefore, the process requires routine and extensive disclosure of past abuses and experiences to numerous individuals by the claimant. ${ }^{73}$ What primarily differentiates the Independent Assessment Process and the Alternative Dispute Resolution Process is the experience of adjudication. The Assembly of First Nations recommended a gentler approach to adjudication following the failure of the ADR mechanism (see AFN 2004), but it is through this approach that the therapeutic ethos may find an entry point.

Despite Winter's insistence the Indian Residential Schools Settlement Agreement should transcend a therapeutic ethos, IAP adjudicator Michael Bay (2013) asserts that the Independent Assessment Process constituted a much needed experiment in "jurisprudential therapy" (1). Bay's neologism is derived from a legal principle called therapeutic jurisprudence that serves as an ideological lens to frame the legal process, its outcomes, and the behaviours of legal practitioners. Primarily designed to address the potential shortcomings embedded in a positivist and objectivist interpretation of the law, therapeutic jurisprudence scholars imagine the law as a "helping profession" (Wexler, 126) where legal proceedings and practitioners provide therapeutic processes and outcomes that "assist in the psychological recovery of the survivor" (Feldhusen, Hankivsky, Greeves 2000, 68). While the definition of what is "therapeutic" has been left "intentionally vague" by therapeutic jurisprudence scholars and practitioners, this terminology exemplifies a need for client-centered and non-adversarial approaches to legal processes (Hankivsky 2004, 63). Therapeutic outcomes are automatically perceived by certain legal scholars and practitioners to be positive for the claimant because the legal system is presented as lacking empathy and attention to

\footnotetext{
${ }^{73}$ Following a Western psychotherapeutic approach, therapeutic jurisprudence advocates suggest that disclosure is necessary for healing to taking place. Yet, the act of disclosure is very difficult even in a safe environment: repeated disclosure to institutional personnel who are not professional counsellors may result in the re-victimization of the claimant (see Hankivsky 2004; Aboriginal Healing Foundation 2008).
} 
individual circumstance. Under a therapeutic jurisprudence model, "appropriate redress for harms is often reduced to monetary compensation synonymous with tort law" (Hankivsky 2004, 61) and reparations are deployed "to put injured persons in a position that they would have been in if they hadn't been subjected to this accident. It is clumsy, but it is designed to try to make them whole" (Wexler 2005, 126) ${ }^{74}$ While this approach may make the legal process seem less impersonal, as the categorization of harms and reparations become increasingly personalized the process may ignore the impact of systemic abuses.

Despite his tacit endorsement of therapeutic jurisprudence, Michael Bay (2013) cautions that a therapeutic approach to compensating for residential schools harm and abuse may "risk [sic] using the power and authority invested in it in a paternalistic way that deprives people of the right to be heard and tramples the basic principles of informed consent to therapy" (1). This is illustrative in Bay's (2013) own professional experience:

Many, many claimants tell us that the hearing has been a catharsis, the start of their healing. They often come into the hearing nervous and leave optimistic and upbeat. I frequently see a profound change in body language, with heads down and stooped shoulders at the outset but straight shoulders and high heads at the conclusion. (4)

This quote suggests that he has transformed a claimant's life, not through the provision of reparations, but through the therapeutic experience of adjudication. A belief that the act of disclosure can improve an individual claimant's quality of life may have some plausibility, however, this view may bolster facile assumptions that reconciliation requires only the acknowledgement of past harm and trauma instead of the implementations of substantive structural change and decolonization.

\footnotetext{
74 Wexler's assessment of compensation strongly resembles John Torpey's (2006) reference to the practice reconciliation and redress as a means to "make whole what has been smashed."
} 
However, Bay (2013) also makes another point which helps to illustrate my argument further when he suggests that "procedural protections and the necessity for legal proof" will be sacrificed "on the alter of paternalism or therapy" (5). Both Bay and Winter appear concerned that justice will be sacrificed for therapeutic proceedings. Instead of seeing law and therapy as two different approaches to reparations, I suggest that the Independent Assessment Process institutionalizes a therapeutic approach to the law and that legal procedures allows a therapeutic ethos to discipline Indigenous subjects. Stated more clearly, Bay (2013) and Winter (2011) fear that justice will be sacrificed for therapy, but I argue that it is when the therapeutic ethos coincides with the rule of law that reparations become potentially damaging.

In the following section, I examine how therapeutic logics become deeply embedded within the legal framework through the forms used by the Independent Assessment Process (IAP) as modes of quantification and categorization. I analyze the language of the IAP forms to examine the specific ways that Indigenous claimants are categorized in the reconciliation process and how the calculation of loss and abuse individualizes residential school trauma, which leaves the process vulnerable to neoliberal co-optation.

\section{No Points for Guessing: The Medicalization of Abuse}

Underpinning Olena Hankivsky’s (2004) advocacy for a therapeutic jurisprudence model is the belief that the application of a therapeutic ethos would benefit victims of violence because the legal "system is adversarial and impersonal" (61). Yet, one of the ways in that the compensation is depersonalized is through the forms that claimants must to fill out in order submit a claim for reparations. The politics of the bureaucratic form requires consideration in the study of reparations because it is by way of application documents that specific categories are created to represent residential school experiences and the possibilities for compensating its problematic outcomes. 
Independent Assessment Process claimants must fill out a form detailing their experiences in residential schools, their ongoing symptoms and the way in which these experiences have blocked their opportunities for growth and success. The categories (namely, "Abuse," "Effects of Abuse," and "Loss of Opportunity") used in the Independent Assessment Process directly coincide with the Guide to the Redress Scheme that was designed for the Residential Institutions Redress Act (2002) in Ireland, and amended by the Commission to Inquire into Child Abuse (Amendment) Act (2005). Taking this into account, in this section I ask: How do the politics of bureaucratic forms and quantification engender the notion of compensation as a therapeutic investment?

To begin the Independent Assessment process, claimants are asked to fill out a 19-page application form and submit this information to the Adjudication Secretariat for evaluation, after which attorneys help facilitate the scheduling of the hearing. As I will demonstrate below, the forms provide several categories that claimants can use to document their experiences of suffering. These categories can also be used to measure traumatic experience and translate these experiences into monetary recompense. Forms and documents are understood by most state institutions and legal practitioners as neutral tools used to document important information about a claimant's history. I argue that this belief in neutrality bolsters uncritical assumptions that the collection of information is necessary and will ultimately lead to positive results. Scholars have identified a particular politics associated with the collection of information through bureaucratic forms. For example, in his discussion of normativity, gender categories and legal forms, Dean Spade (2011) notes:

We are used to filling out forms with certain questions. We rarely question how we came to be asked for these particular pieces of information and not others except in moments when we personally have a hard time figuring out which box to check off. Because certain classification become common or standard, there is often an implied shared understanding that certain things, like gender, are just necessary information for administering government programs. (141) 
As I demonstrated in Chapter Two, while categorizing claimants in relation to their suffering is prevalent in tort-based compensation processes, it is important to question who this categorization benefits since,

$[t]$ he terms and categories used in the classification of data gathered by the state do not really collect information about pre-existing types of things, but shape the world into those categories that ultimately, are taken for granted by most and thus appear as ahistorical and apolitical. Indeed, many such categorizations are assumed as basic truths. (Spade 2011, 141)

For instance, categories established through bureaucratic forms support assumptions about normal and abnormal behaviours and experiences. Therefore, the Independent Assessment Process' categories may perpetuate a number of settler assumptions about Indigenous peoples' collective victimization, addiction or poverty, as outlined in the introduction of this chapter. These assumptions bolster settler and neoliberal projects that insist on the assimilation of Indigenous peoples for them to financially prosper and "feel better."

First and foremost, claimants are encouraged to utilize the Independent Assessment Process Guide for assistance on how to fill out the forms securely and accurately. The Guide introduces the three categories to the applicant that correspond to a basic linear temporality of residential school experience: Levels of Abuse, Effects of Abuse, and Loss of Opportunity (or Actual Income Loss). As I outlined in Chapter Four, cultural and language loss has been highlighted by survivors as an important grievance, but pursuant to the initial reports of institutional abuse in Canada (Law Commission of Canada 1998; 2000). As I will demonstrate below, the criteria of sexual and physical abuse serves as the main impetus for compensating former residential school students through the Independent Assessment Process, and therefore, the cultural/linguistic consequences of child removal are viewed as worthy of less recompense. 
The Independent Assessment Process utilizes universal categories to document claimant harm, specifically under the guise of fairness. This means that claimants are organized through specific categories to ensure that reparations are distributed fairly, even if they are being distributed by many different adjudicators. However, while the categorization of harm is helpful for documentation, the assessment of reparations is enacted through modes of quantification. The use of numbers and accounting is helpful in making an abstract concept into a tangible or material thing (see Nelson 2015, 25-7). However, calculating abstracts for the purposes of monetization has specific ramifications, the most important being, as David Graeber notes, "money's capacity to turn morality into a matter of interpersonal arithmetic - and by doing so, to justify things that would otherwise seem outrageous or obscene" (qted. Joseph 2015, 7-8). I draw attention to the use of quantification in the Independent Assessment Process because the process was designed to be less adversarial for Indigenous claimants than the Alternative Dispute Resolution Mechanism. Yet, as I will demonstrate in the following paragraphs, the quantification of crisis, trauma and dysfunction is nearly identical in both processes.

Before, I examine the Independent Assessment Process, I think it is important to provide a history of quantification methods that were employed by the Alternative Dispute Resolution Mechanism. As part of the 40-page form, claimants were asked to provide information about the harms that they experienced at the hands of residential school staff. A series of categories with associated compensation amounts was devised so that legal practitioners could award compensation to claimants "fairly" (see Bay 2013). To make a decision on the extent of abuse experienced, the adjudicator was asked to reference a grid system where points were allotted for specific harms experienced. In reducing harms to a specific number of points, a rudimentary 
system of accounting was used to establish the compensatory award. Funk-Unrau and Snyder (2007) note that

the actual amount awarded is determined on a point system, with varying numbers of points awarded depending on the severity of the abuse, the political jurisdiction within which the abuse occurred, and whether the abuse was committed by a person representing a religious group that has entered into some form of cost-sharing agreement with the federal government. (294)

For this reason, claimants were asked to classify their claims within one of two major categories that would link their experiences to a specific compensatory formula that was pre-determined by government officials:

Category A covers those who are considered to have suffered serious abuse: sexual abuse or physical abuse resulting in injuries lasting more than six weeks or requiring hospitalization or serious medical treatment. (Funk-Unrau and Snyder 2007, 294)

Claimants who applied to this category were entitled to a maximum of $\$ 240,000.00$ as financial recompense for harms that were experienced (see Funk-Unrau and Snyder 2007). Accordingly, only egregious acts of sexual assault and physical violence were worthy of recompense and the decisions to extend compensation monies were left in the hands of government adjudicators. Any injuries emanating from language and cultural loss were catalogued under Category B, and "[t]he maximum compensation for category B claims, which are considered less serious, [was] generally fifteen hundred dollars, although there [was] provision for providing up to thirty-five hundred dollars depending on aggravating factors of the abuse" (Funk-Unrau and Snyder 2007, 294). By creating these categories, the settler state ranked the experiences of harm in order to contain the monies that were to be paid out through the Alternative Dispute Resolution Program. This meant that certain categories of harm (experienced by all former students), such as loss of culture and language, were afforded only nominal recompense (see Funk-Unrau and Snyder 2007, 294). Therefore, a hierarchy of harms was created which obscures the systemic violence of the 
residential school system as a whole (see Chapter Three). While the Independent Assessment Process diverges from the Alternative Dispute Resolution Mechanism in many ways, quantification is still employed alongside a more therapeutic approach to adjudication.

The Independent Assessment Process operates on a points system to ensure the fair distribution of compensatory claims. Each categorical experience is assigned a specific number of points which are then added up by the adjudicator in order to calculate the claim. According to Michael Bay (2013), the adjudicators for the Independent Assessment Process utilize "[a] special rulebook" that was designed "to that set out the procedures to be followed" (3). This rulebook

uses a sophisticated point system for various kinds of and severity of assaults as well as the levels of psychological and employment impact of those assaults and established a compensation grid based on points arrived at in order to mirror, as closely as possible, what the superior courts would award in similar circumstances. It was recognized that the seriousness of the abuse would not translate directly into a given level of harm, that no two people would be impacted in the same way from any given level and type of abuse. (Bay 2013,3)

According to this quote, the different categories of harm and psychological impact are meant to portray the experience of harm as a specific and individual experience. Yet, individualising these experiences, as though they somehow occurred in a vacuum, obscures the fact that they were a direct result of state policy and influenced by the perpetration of colonial violence.

The effectiveness of this point system has been questioned by Mark Cherrington (2011) who suggests that utilizing a points system in this context is tantamount to a "diabolical board game" where "the points have dollar values attached to them. The more points you gather, the more money you get" (n. pag.) ${ }^{75}$ Economizing pain and suffering through a point system such as the one used in the Independent Assessment Process "often involves attempts to measure loss and

75 Henderson and Wakeham (2009) have also noted that the "reliance upon a point-based scale that calculates monetary value via the reduction of traumatic experience to itemization within a clinical taxonomy of injuries has also raised questions about the 'reconciliatory' potential of such a juridical tabulation of suffering" (11). 
can quantify what is arguably not quantifiable" (Blackburn 2012,295). Repressive accounting practices used in juridical negotiations were also used to render grievances as "“calcuable' or somehow 'measurable,' thus making them governable" by institutional gatekeepers (Lindroth 2014, 350). The economic calculus and categories of perpetration designed by government and legal representatives directly undermined The Canadian Bar Association's recommendation that claimants should have authority to define the compensation criteria and the nature of their individual or transgenerational injuries (Canadian Bar Association 2005, 24). The individualization of suffering and payments enacted through ADR processes (and later the IRSSA) demonstrates a neoliberal influence on the structure of compensation and redress. Both the experiences of victimization and perpetration are not only individualized but are deemed "exceptional," which obscures the systemic violence of the schools themselves as state institutions. Even the claimant's participation in the compensation process has been theorized through economic rhetoric. Morrissette and Goodwill (2013) assert that "[u]ltimately, survivors enter into a cost-benefit analysis and carefully weigh the consequences of disclosing their abuse" (548, emphasis mine), which immediately links therapeutic and economic logics in the receipt of compensation.

When submitting the application, the claimant is asked to enter their personal information, and to identify which type of claim they wish to pursue (standard or complex track, which I outline in Chapter Three). Following this, Section 2 of the application form is entitled Indian Residential School Identification, which is where the claimant is asked to identify the school(s) they attended and during what time period (specific years include start and end dates). ${ }^{76}$ The Independent

\footnotetext{
${ }^{76}$ Before proceeding to Section 3, the claimant is alerted that the following sections "may trigger certain memories and bring painful feelings. Because of this, we suggest that you take as much time as you need and that you be in a safe place when you look at and answer these questions" (Independent Assessment Process Secretariat 2011, 8). The trigger warning provided at the opening of the application implies that applicants may have adverse experiences
} 
Assessment Process Guide warns that: "If you do not know the answers to any of the points above, do not guess. Just provide as much detail as you remember" (Independent Assessment Process Secretariat 2011,16$).{ }^{77}$ This statement immediately positions the claimant as an unreliable witness. $^{78}$

After filling out the table, the claimant is then asked to reference each event listed in the codified chart they have previously filled out, and to detail their experiences "in their own words." The demand to articulate instances of abuse functions as an exercise in corroborating the claimant's testimony by being continually asked to re-visit it. The next two categories on the application to the Independent Assessment Process correspond to the duration of abuse and its effects on the development of the Survivor. These classifications depend on the severity of the abuse, and a numerical total of points describing this severity is then allotted to each applicant.

The next section of IAP application is entitled The Abuse. Here the claimant is required to fill out a "table of the abuse," detailing the experiences they have suffered to which they are willing to attest during adjudication. This table contains four columns: Incidents of Abuse, Level of Abuse, Approximate date(s) When Abuse Occurred, and Who Abused You. The claimant is asked to provide the approximate dates of abuse and to identify the person who abused them and the abuser's position in the institution. ${ }^{79}$ When identifying the perpetrator of an individual's

\footnotetext{
during the application process as a result of having experienced past trauma, since critics have noted that this could potentially overwhelm the applicant even at the form stage.

${ }^{77}$ From here on out, reference to the Guide will read "Independent 2011".

${ }^{78}$ The initial question in this section asks the claimant to identify the school of attendance so the adjudicator can verify their eligibility and the viability of their story by cross-referencing employment records of staff who were there at the same time. Some claimants recall being asked to remember exact details of the former residential schools during the adjudication process, which is a difficult task since these crimes and violations were experienced during the claimant's childhood (CBC News 2013 a, n. pag.).

${ }^{79}$ This is an important to the Independent Assessment Process because this process is meant to compensate for student on student abuse as well. According to Ronald Niezen (2013,53-4), once a person is identified on an application form as a possible perpetrator, the person is sent a letter informing them that they have been identified as a person of interest in an IAP application. As these letters are sent to community members, this has led to an incredible amount of suspicion which has circulated through particularly small communities.
} 
experience of abuse, the applicant is asked to make reference to systemic problems in the schools themselves that they may not be able to recall. For instance, if the claimant is reporting abuse by another student during their time in residential school, the claimant must answer questions regarding the supervision at the school and to assess the knowledge of school supervisors that may have known about any abuse that was occurring in the institution (Independent 2011, 17). This is a particularly difficult question for a claimant to answer since they would not have been privy to this information, and therefore, these responses are potentially speculative.

In the next section, the application provides claimants with a blank chart in which in they are asked to describe each instance of abuse that they experienced during their time at residential school. To help applicants to express their experiences cogently, the IAP Application Guide (2011) provides a rubric of abuse to prompt claimants to code their abuses clearly, based on abuse "type" and "frequency."

\begin{tabular}{|c|c|}
\hline Level & Description \\
\hline $\begin{array}{l}\text { SL5 } \\
\text { Sexual abuse } \\
\text { level } 5\end{array}$ & $\begin{array}{l}\text { - Repeated, persistent incidents of anal or vaginal intercourse. } \\
\text { - Repeated, persistent incidents of anal or vaginal penetration with an object. }\end{array}$ \\
\hline $\begin{array}{l}\text { SL4 } \\
\text { Sexual abuse } \\
\text { level } 4\end{array}$ & $\begin{array}{l}\text { - One or more incidents of anal or vaginal intercourse. } \\
\text { - Repeated, persistent incidents of oral intercourse. } \\
\text { - One or more incidents of anal or vaginal penetration with an object. }\end{array}$ \\
\hline
\end{tabular}




\begin{tabular}{|c|c|}
\hline $\begin{array}{l}\text { SL3 } \\
\text { Sexual abuse } \\
\text { level } 3\end{array}$ & $\begin{array}{l}\text { - One or more incidents of oral intercourse. } \\
\text { - One or more incidents of digital anal or vaginal penetration. } \\
\text { - One or more incidents of attempted anal or vaginal penetration (excluding } \\
\text { attempted digital penetration). } \\
\text { - Repeated, persistent incidents of masturbation. }\end{array}$ \\
\hline $\begin{array}{l}\text { PL } \\
\text { Physical abuse }\end{array}$ & $\begin{array}{l}\text { - One or more physical assaults causing a physical injury that: } \\
\text { o led to or should have led to hospitalization or serious medical treatment by } \\
\text { a physician } \\
\text { o caused permanent or demonstrated long-term physical injury } \\
\text { o impaired or disfigured } \\
\text { o caused loss of consciousness } \\
\text { o broke bones } \\
\text { o caused serious but temporary incapacitation requiring bed rest or infirmary } \\
\text { care for several days. Examples include severe beating, whipping, and } \\
\text { second-degree burning. }\end{array}$ \\
\hline $\begin{array}{l}\text { SL2 } \\
\text { Sexual abuse } \\
\text { level } 2\end{array}$ & $\begin{array}{l}\text { - One or more incidents of simulated intercourse. } \\
\text { - One or more incidents of masturbation. } \\
\text { - Repeated, persistent fondling under clothing. }\end{array}$ \\
\hline $\begin{array}{l}\text { SL1 } \\
\text { Sexual abuse } \\
\text { level } 1\end{array}$ & $\begin{array}{l}\text { - One or more incidents of fondling or kissing. } \\
\text { - Nude photographs taken of the Claimant. } \\
\text { - The act of an adult employee or other adult lawfully on the premises } \\
\text { exposing themselves. } \\
\text { - Any touching of a student, including touching with an object, by an adult } \\
\text { employee or other adult lawfully on the premises which exceeds recognized } \\
\text { parental contact and violates the sexual integrity of the student. }\end{array}$ \\
\hline
\end{tabular}




\begin{tabular}{|l|l|}
\hline OWA & $\begin{array}{l}\text { - Being singled out for physical abuse by an adult employee or other adult } \\
\text { lawfully on the premises which was grossly excessive in duration and } \\
\text { Other } \\
\text { frequency and which caused psychological consequential harms at the H3 } \\
\text { level or higher. } \\
\text { - Any other wrongful act committed by an adult employee or other adult } \\
\text { lawfully on the premises which is proven to have caused psychological } \\
\text { consequential harms at the H4 or H5 level. }\end{array}$ \\
\hline
\end{tabular}

(Chart reference: Independent 2011, 15)

The student is required to describe their experience of abuse and then match it with a corresponding code in the adjacent column, in order to make assessment easier for the adjudicator. Documenting the experience of abuse and harm is only the first part of the tort-based approach to receiving reparations through a compensation process. After the harms are documented, claimants are required to associate these harms with particular outcomes, and it is actually the outcomes of the harm which are compensated for. In testifying to the harmful acts visited upon their bodies in residential schools, claimants must in fact testify to the dysfunction that these harms manifested in their daily lives. Disclosure in this setting not only requires admitting victimization but also testifying to their own dysfunction.

The disclosure of harm and associative dysfunction is presented as a means to determine the severity of the harm experienced by the claimant. Section 4 asks claimants to describe "the emotional or psychological effects of the abuse you suffered at residential school" (Independent $2011,18)$. In doing so, the claimant is also encouraged to "connect these effects to the abuse you described" in Section 3. The following chart documents how the "harms" are described through the Independent Assessment Process:

\section{Level of Harm}

\section{Description of harm that resulted from your abuse}




\begin{tabular}{|l|l|}
\hline H5 & $\begin{array}{l}\text { Continued harm resulting in serious dysfunction Evidenced by: } \\
\text { - psychotic disorganization, loss of ego boundaries, personality disorders, } \\
\text { pregnancy resulting from a defined sexual assault or the forced termination of } \\
\text { such pregnancy or being required to place for adoption a child resulting from } \\
\text { such a pregnancy, self-injury, suicidal tendencies, inability to form or } \\
\text { maintain personal relationships, chronic post-traumatic state, sexual } \\
\text { dysfunction, or eating disorders }\end{array}$ \\
\hline H4 & $\begin{array}{l}\text { Harm resulting in some dysfunction Evidenced by: } \\
\text { frequent difficulties with interpersonal relationships, development of } \\
\text { obsessive-compulsive and panic states, severe anxiety, occasional suicidal } \\
\text { tendencies, permanent significantly disabling physical injury, overwhelming } \\
\text { guilt, self-blame, lack of trust in others, severe post-traumatic stress disorder, } \\
\text { some sexual dysfunction, or eating disorders. }\end{array}$ \\
\hline H3 & $\begin{array}{l}\text { Continued detrimental impact Evidenced by: } \\
\text { - difficulties with interpersonal relationships, occasional obsessive } \\
\text { compulsive and panic states, some post-traumatic stress disorder, occasional } \\
\text { sexual dysfunction, addiction to drugs, alcohol or substances, a long term } \\
\text { significantly disabling physical injury resulting from a defined sexual assault, } \\
\text { or lasting and significant anxiety, guilt, self-blame, lack of trust in others, } \\
\text { nightmares, bed-wetting, aggression, hyper-vigilance, anger, retaliatory rage } \\
\text { and possibly self-inflicted injury. }\end{array}$ \\
\hline H2 & $\begin{array}{l}\text { Some detrimental impact Evidenced by: } \\
\text { panic states, hyper-vigilance, retaliatory rage, depression, humiliation, loss of } \\
\text { self-esteem. } \\
\text { stress disorder, self-blame, lack of trust in others, and low self-esteem; and/or } \\
\text { several occasions and several symptoms of: anxiety, guilt, nightmares, bed- } \\
\text { wetting, aggression, panic states, hyper-vigilance, retaliatory rage, } \\
\text { depression, humiliation, loss of self-esteem. }\end{array}$ \\
\hline Modest Detrimental Impact Evidenced by: \\
\hline Occasional short-term, one of: anxiety, nightmares, bed-wetting, aggression, \\
\hline
\end{tabular}


(Chart reference: Independent 2011, 19)

The nature of harm described in this chart warrants a return to the different definitions of trauma and healing that I provided at the beginning of this chapter. The outcomes of residential school experiences are described through a specific symptomology that relies entirely on a Western conceptualization of individual pathology. Primarily, these symptoms demonstrate a PostTraumatic Stress typology that relies on a diverse symptomology that includes addiction, aggression, and anxiety as indicators of pathological behaviours. As I will argue below, the medicalization of individual pathology is particularly important to the therapeutic investment in compensation, because individual harm functions as an explanation for issues that are intimately connected to economic dependency and social inequality. This framework situates trauma as an Indigenous "problem" that can be resolved through the receipt of a monetary award. What is continuously obscured by this focus on harm is the role of the state in perpetuating this harm, through both historical and contemporary policies and practices.

The "medicalization thesis" identifies a reliance on the "medical frame...to understand or manage" various social problems (Conrad quoted in Cvetkovich 2010, 211). While I acknowledge that trauma and suffering should not be considered external to the domain of medicine, it is important to note how medicine perceives psychic trauma (harm) as a malady requiring medical diagnosis and intervention to ensure the individual's recovery. Anti-colonial and queer scholars have insisted that pain and suffering is a social phenomenon that adversely affects victims of violence and oppression in numerous ways (Ahmed 2005; Cvetkovich 2012; Cowlishaw 2003), which is particularly salient to understanding its level of frequency in Indigenous communities (see Adelson 2000; Alfred 2009 b; Kirmayer and Valaskasis 2008; Million 2013). 
A medical frame implies that individual "victims" are diagnosed as "suffer[ing] from an 'illness,' that can be 'cured' within existing or slightly modified structures of institutionalized medicine and psychiatry" (Tal 1996, 6). Medicalization may displace collective contestation of material inequality because it focuses on the diagnosis of individual symptoms and forms of treatment. Therefore, critics of the "medicalization thesis" instead argue that instances of depression or stress are socially manifested through inequitable socioeconomic relationships and are not an illness presented by an individual (Lupton 2003). The medicalization of trauma in the Independent Process is further enacted by a requirement that the claimant "describe the treatment you received for your physical injuries" (Independent 2011, 18) as a means of insisting on proof of "treatment," for which the claimant is then also required to amass accompanying documentation as proof. ${ }^{80}$ In disclosing their previous treatment, whether medical, counselling, or visitation to a "traditional healer," the claimant must participate in a process whereby they testify to their dysfunction and their need for help.

Compensation is bestowed by legal "experts" who rely on documentation from medical experts through techniques of categorization and quantification. This expertise is not an exercise of direct social control but "of enacting assorted attempts at the calculated administration of diverse aspects of conduct through countless, often competing, local tactics of education, persuasion, inducement, management, incitement, motivation and encouragement" (Rose and Miller quoted in Larner 2002, 653). For this reason, the subjectivities that are constructed through the compensation

80 Documentation includes: relevant treatment records such as clinical, hospital and medical records (but not counselling records); worker's compensation records (if your claim involves a physical injury); corrections records such as in-take assessments, medical records, psychiatric and psychological records, parole hearing records, discipline records and pre-sentencing reports (insofar as they relate to injuries or harms); income tax records; employment insurance records; Canada Pension Plan records; non-residential secondary school records; and postsecondary school records (see Independent 2011,38). 
process can be taken up elsewhere in society and applied to other forms of social management and social organization.

The emphasis on illness and symptoms that are persistent in the opening sections of the application are inherently linked to a therapeutic approach to the provision of compensation. Testifying to the experience of historical trauma is double-edged, in that it may de-stigmatize mental health issues associated with the abuse experienced by residential schools students and helps to affirm the suffering of claimants. However, in testifying, students must avow to (and prove) their injury in order to receive compensation, which lends their experiences to discourses of victimhood. The receipt of compensation is based on the recognition and verification of the harms experienced. While the collection of information concerning traumatic experiences may seem necessary to deliver appropriate compensation, I argue that the categories utilized in these forms enable the financialization of problematic histories and bodies through a medicalized lens. Since attention to systemic and ongoing forms of oppression is displaced by medicalized definitions of trauma, the meaningful nature of compensation may be sacrificed in the name of efficiency and universality, and under the guise of therapeutic intervention. As I will demonstrate in the next section, linking mental health to unemployment may help buttress ongoing presumptions that Indigenous peoples need to "get better" as a means to fulfil personal aspirations and contribute to the Canadian nation-state.

\section{Employing Trauma}

In the previous section, I noted how bureaucratic categories and methods of quantification work in tandem in order to individualize harm and loss in the Independent Assessment Process application forms. In the process, Indigenous claimants are constructed as medicalized subjects who are forced to testify to their own dysfunction to receive reparations. Throughout this process 
the systemic violence of the residential school system is obscured. In re-directing the locus of trauma from the individual to an examination of the social relations that they inhabit, queer scholars have suggested that constructions of normativity (primarily those created and maintained by dominant society) can be revealed. The authority to define and separate "normal" identities and behaviours from the "abnormal" or dysfunctional is a primary site of power for the settler state. The use of compensatory categories engenders a conceptualization of a normative citizen who must contribute to the wage economy and minimize their dependence on social services. Economic contribution and financial self-management is then equated with a healthy, functioning individual.

The Alternative Dispute Resolution Mechanism was described by Bob Watts, former counsel for the Assembly of First Nations, as a "very legalistic approach, almost like a worker's compensation approach to harm" (Spear 2014, 175). Given the similarities between the compensation frameworks, I assert that the Independent Assessment Process continued to impose this kind of categorization when assessing residential school claims. This section examines the consequences of equating the loss of work opportunity with a lack of self-esteem or psychological illness due to abuse at residential schools. Building on critiques of the medicalization thesis, I argue that a "workers' compensation" framework not only ignores the socio-economic constraints placed on Indigenous peoples through Indian Act governance, but it discounts the welldocumented inequalities Indigenous peoples experience based on their limited access to education, healthcare, housing, and even clean water, that may contribute to ill health in Indigenous communities (see Auditor General 2011).

Political economy of health scholars suggest that the medicalized definition of health is framed "as the ability to work," since the "healthy person is the person who produces" (Lupton 2003, 108; see also Orisini 2007, 349-50). For this reason, processes that establish ill health as a 
compensatory category may use economic indicators, particularly employment, as a measuring

stick to assess the extent of damage. Deborah Lupton (2003) suggests that the

institution of medicine exists to attempt to ensure that the population remains healthy enough to contribute to the economic system, as workers and consumers, but is unwilling to devote resources for those who do not respond to treatment and are unable to return to the labour market. Medicine thus serves to perpetuate social inequalities, the divide between the privileged and the underprivileged, rather than ameliorate them. (8)

Moreover, normative categories are established through indicators of "good" or "bad" health, since “[c]apacity and debility are seeming opposites generated by increasingly demanding neoliberal formulations of health" (Puar 2012, 153). ${ }^{81}$ Writing about the politics of the Alternative Dispute Resolution Mechanism, Carole Blackburn (2012) identifies how the enunciation and application of grievance is re-articulated through the neoliberal project:

Those who make claims on the state are judged negatively in relation to those who manage to pull themselves up by their bootstraps. This is not new, but in the current ascendancy of neoliberalism, good citizenship is increasingly defined as the duty of individuals "to reduce their burden on society," to maximize their individual capital and be "entrepreneurs of themselves." (Blackburn 2006, 75) ${ }^{82}$

\footnotetext{
${ }^{81}$ I argue that there is a correlation between the definition of those deserving of compensation and the way in which disabled persons are defined under the law as way to get receipt of tax or program benefits. For instance," $t$ t]o qualify for a disability benefit under the Canada Pension Plan (CPP), a disability must be both 'severe' and 'prolonged,' and it must prevent you from being able to work at any job on a regular basis. Severe means that you have a mental or physical disability that regularly stops you from doing any type of substantially gainful work. Prolonged means that your disability is long-term and of indefinite duration or is likely to result in death" (Canada 2015, n.pag.). Moreover, the Ontario Disability Support Program's definition of disability is explicitly related to work: "Person with a disability 4. (1) A person is a person with a disability for the purposes of this Part if, (a) the person has a substantial physical or mental impairment that is continuous or recurrent and expected to last one year or more; (b) the direct and cumulative effect of the impairment on the person's ability to attend to his or her personal care, function in the community and function in a workplace, results in a substantial restriction in one or more of these activities of daily living; and (c) the impairment and its likely duration and the restriction in the person's activities of daily living have been verified by a person with the prescribed qualifications" (n. pag.).

${ }^{82}$ While I assert that the medicalization of social problems has dire consequences, I also recognize that critique of medical or therapeutic models can be co-opted by the neoliberal logic. For instance, critics of the therapeutic such as James Nolan (1998) note that the medicalization of alcoholism or violent behaviour compromises an individual's ability to take "responsibility" for their actions. The language of responsibility denies the social causation of individual distress or pathological forms of coping, and more generally, leaves categories of dysfunction left unquestioned. Therefore, while the medical and therapeutic models are fundamentally refuted in this chapter, my analysis is based on queer and anti-colonial frameworks that situate trauma and suffering as socially constructed phenomena instead of relying on the categorization of disorders or the impact of character flaws.
} 
Reforming social welfare to reflect capitalist ideology is a distinctly neoliberal approach, since compensation is presented as a mechanism to ensure social mobility for "hard-working" individuals or their descendants. Barbara Cruikshank (1996) states that "[s]elf-fulfilment is no longer a personal or private goal. According to advocates, taking up the goal of self-esteem is something we owe to society, something that will defray the costs of social problems, something that will create a 'true' democracy" (232). In short, publicly feeling well is now the responsibility of the individual citizen, and if they are unable to achieve health and productivity on their own, then "feeling bad" is registered as a cost or a missed contribution.

Central to my analysis in this section is the examination of the conflation of injury and unemployment in the Indian Residential Schools Settlement Agreement's "loss of opportunity" criterion. Loss of opportunity is defined through the claimant's psychosocial debilitation assessed through their ability to obtain or sustain employment as a result of deteriorating mental health. As I demonstrated in the previous chapter, categories of unemployment reinforce the notion that Indigenous peoples are a "cost" to the settler state. Therefore, the co-constitutive categories of injury and worklessness (Brambra 2011) reify conceptualizations of Indigeneity as dysfunctional, and thereby legitimize prevailing assumptions about their inability to contribute to Canadian prosperity.

In the final section of the IAP application the claimant is required to provide "details of your formal education or training, or both" (Independent 2011, 20). The subsequent question asks the claimant to provide details of their "work history, including times of unemployment," as well as instances when the claimant was "employed" (Independent 2011, 20). In addition, "reasons for unemployment" are required, including details such as whether the claimant "quit" a job or was "fired" or "became ill (physically, emotionally, psychologically)" (Independent 2011, 20). 
Question 3 requires the claimant to identify “opportunities you may have lost because of the effects of your abuse" (Independent 2011, 20). Claimants are prompted by the language in the guide to provide rationales, such as "not being able to finish an educational program because of the effect(s) of the abuse you suffered at residential school" (Independent 2011, 20), to help guide the adjudicator. While these questions do not seem particularly relevant to the "rating" of residential school trauma, the IAP Guide notes that these answers are meant to "help the Adjudicator understand what income you may have lost because of your abuse" (Independent 2011, 20). Question 4 indicates that "[i]f you are claiming loss of opportunity or actual income loss, please check the appropriate box" (Independent 2011, 20). However, if the claimant is applying for actual income loss, they must demonstrate a "direct connection between the effects of the abuse you suffered and your inability to keep working" (Independent 2011, 22). At the same time, the claimant is reminded that "[t]his is sometimes difficult to do because other things could have made you unable to work" (Independent 2011, 22). While this information may provide some opening to acknowledge how Indigenous peoples have suffered joblessness for numerous reasons, it is clear that no action will be taken to rectify the situation. Taking this into account, the language of the form seemingly categorizes the individual claimant as lacking employment due to "dysfunction" rather than relating the experience of unemployment to ongoing structural inequalities. ${ }^{83}$

The categories utilized in the Independent Assessment Process identify dysfunction through medical documentation and missed work. These categories engender assumptions that

\footnotetext{
83 The Irish Redress Process identified "loss of opportunity" as a result of illiteracy, lack of identification or inability to gain employment due to "criminal" records. However, the Canadian compensation process offered the much broader categories that I have listed above. The primary difference is that loss of opportunity in the Irish compensation claim is based on poor education received from the school or as a result of harm. The broader Canadian categories may reflect a better and more important "classification," such as taking into account how the difficulty of working in an institutionalized environment, or problems with authority, could complicate job-seeking for Survivors of abuse (Compensation Advisory Board 2002, 73).
} 
those who were able to continue to work were not thoroughly traumatized by the residential school experience and, therefore, may be less entitled to compensation. The following chart is the final set of categories which the applicant is required to address on their application form:

\begin{tabular}{|l|l|}
\hline Level & Loss of Opportunity \\
\hline OL5 & Chronic Inability to get a job \\
\hline OL4 & Chronic Inability to keep a job \\
\hline OL3 & Periodic or occasional inability to get or keep a job \\
\hline OL2 & $\begin{array}{l}\text { Inability to start or finish education or training, resulting in underemployment } \\
\text { or unemployment }\end{array}$ \\
\hline OL1 & Reduced work capacity-physical strength, or attention span \\
\hline
\end{tabular}

(Chart taken: Independent 2011, 21)

The IAP Guide (2011) defines loss of opportunity as meaning that "the effects from the abuse you suffered have kept you from reaching a higher level of education or getting a better job" (21). Claimants are then asked to address and detail how they have been unsuccessful in obtaining education due to "trouble concentrating or listening to authority figures after what happened to you at Indian Residential School, or for some other reason" (IAP Guide 2011, 21). The AFN Report on the Response to the Alternative Dispute Resolution Mechanism (2004) suggested that "the consequences of the abuse must be weighted more heavily than acts of abuse in the compensation calculations" (4). Yet, if we are utilize the categories established by the Independent Assessment Process, the experiences of violence and the outcomes it produced are considered to be individual experiences to be accounted for within a system of points. By assessing residential school experiences in such a way, the IRSSA does not acknowledge the pervasive racist and 
discriminatory behaviour routinely enacted against Indigenous peoples in the public sphere. This calls into question the category of "lost" opportunities, since employment opportunities might more accurately be described as having been denied to Indigenous peoples.

Struggles for Indigenous peoples to retain employment in reserve communities due to acts of dispossession and impoverishment are documented by many scholars (see Alfred 2009 b; Irbacher-Fox 2008) and government departments (see Statistics Canada 2006). Therefore, I argue that the "loss of opportunity" criteria draws on "strategies which tend to direct attention away from the socio-economic factors causing the [medical] condition," which "helps legitimize and reproduce social class structure and the economic system" (Lupton 2003, 108) by ensuring that economic dependency in Canada is disguised as a problem of trauma. Discrimination against Indigenous peoples in the workplace has long been documented, and moreover, their participation in the mainstream economy has been vastly curtailed by a lack of economic development on reserves, which is imposed through Indian Act restrictions. The Royal Commission on Aboriginal Peoples Final Report (1996) asserts:

Racism and culturally alien environments have a chilling effect when reports of bad experiences circulate within the Aboriginal community, discouraging others from seeking employment in these workplaces. Added to these barriers are systemic barriers, such as artificial job requirements, lack of knowledge of how the recruitment and hiring systems work, and lack of personal networks to assist in finding job opportunities. Logistical barriers include distance from the job site, lack of work clothing, penalizing welfare regulations and, for reserve residents, the prospect of paying income tax. (Vol.2, 900)

This quote suggests that not only residential schooling, but larger structural issues have kept Indigenous peoples from employment positions. The stigmatization of unemployment has created prevailing myths about the "deserving" and "undeserving" poor, which reinforce Maaka and Fleras' (2005) salient claim that "[t]he problems that confront Indigenous peoples are, paradoxically, mainstream problems and solutions must be addressed accordingly. Indigenous 
peoples should not be framed as failures because of a social system that was unilaterally imposed and enforced upon them" (273). Therefore, the belief in economic viability as a means to unlock some sort of healing potential that is evident in the IAP process reproduces settler assumptions that Indigenous peoples are undeserving poor instead of a population that has been confronted with historically specific obstacles to obtaining meaningful work. What also needs to be addressed is how these discriminatory practices are held in check by both legislative and policy practice.

Assumptions that former students, crippled by historic or residential school trauma, are routinely unemployed have also been challenged. According to Breaking the Silence: An Interpretive Study of Residential School Impact and Healing as Illustrated by the Stories of First Nations Individuals (1994), ${ }^{84}$ the life of adult former IRS students are often characterized by feelings of "being lost," or "staying silent," but also of "working hard." Breaking the Silence examines how former students often shared their experience of career success, yet nonetheless noted that trauma and suffering were ever present. The report states:

For those who did survive, according to statistics, few completed high school and fewer still completed college and university programs. This does not mean that all individuals who left residential school failed to establish themselves in their own 'businesses' or in 'careers' of one kind of another. Some, for example, have certainly taken on leadership roles in their own communities, or in various provincial and national organizations. (Assembly of First Nations 1994, 83, emphasis Assembly)

In the case of former IRS students, guaranteed employment has not automatically equated to happiness; as Breaking the Silence (1994) goes on to suggest, employment may simply have reinforced the colonial logic former students were subjected to, with troubling results. The report states:

\footnotetext{
${ }^{84}$ Million (2013) notes that Breaking the Silence "is also a detailed plan for a movement to heal fragmentation in a spectrum that goes from individual to nations, and through the trajectory that echoes the familiar sequence of trauma, repression, resolution. However, the report calls for an Aboriginal sense of healing that is communal and defined locally" (168).
} 
The need for approval and recognition were issues that former students continued to struggle with for some time. One man who was having difficulty exercising moderation at work, so wanted recognition from his employers, that he ended up becoming a workaholic. Another man made certain that he performed to his highest potential in whatever job he took. However, but [sic] because of the sense of low self-esteem he developed during his attendance at residential school, succeeding in his job fails to make him feel good about himself. (Assembly of First Nations 1994, 98)

The valuable insights in Breaking the Silence (1994) show that the standardization of residential school survivor "trauma" through the lens of economic output in the compensatory framework is not applicable to the experience of everyone who applies. In all likelihood, many former students were gainfully employed or used employment as a means to escape difficult psychological symptoms, and may therefore have their experiences of pain or suffering denied in the legal process of compensation. If worklessness or joblessness can be attributed to medicalized problems inherited from residential school experiences, then compensation will not alleviate this burden of guilt from Canadian society, since discourses of resilience and "success" stories have been used to deny Indigenous peoples' experiences of oppression (see also Henderson 2013).

This section has examined how trauma and loss have been articulated through the category of "loss of opportunity." The categorization of loss generally refers to a loss of education or employment opportunities. I argue that framing individual trauma this way obscures the structural barriers that Indigenous peoples face when attempting to obtain meaningful work. By equating trauma with unemployment, Indigenous peoples who are gainfully employed are viewed as being "without trauma," a point of view that is disputed by the testimonies shared by the Assembly of First Nations. This categorization of Indigenous peoples' residential school experience also reinforces assumptions that Indigenous peoples are a "cost" to the state and that compensation becomes an investment in future employment. 
In the following section, I document how economic development policy and practice is mobilized by government and First Nations leaders to represent and enact reconciliation through the valorization of employment, thereby securing Indigenous peoples' healing as an investment for the settler state.

\section{Economic Development, Reconciliation and Healing}

To explore the concepts of therapy and healing in the contemporary climate of reconciliation, I turn to the speeches and addresses given by the Ministers of Aboriginal Affairs and Northern Development, as well as former National Chief Shawn Atleo of the Assembly of First Nations. These speeches given by Indigenous leaders and Ministers of Aboriginal Affairs are notable not only for their content but for their locations and audiences. Speeches are also an important political text which outline the official positions and goals of Indigenous and government organizations. For instance, in 2012, then INAC Minister John Duncan gave approximately 19 public addresses, of which 4 were directed to various Chambers of Commerce in large Canadian cities (Toronto, Edmonton, Calgary), venues that were then almost immediately visited by then AFN National Chief Shawn Atleo, who was highlighting his "Smashing the Status Quo" campaign. The Crown-First Nations Gathering in January 2012 heard Prime Minister Harper say that he expected "targeted investments in Aboriginal communities" in order to provide economic return for his government's efforts (AFN 2012 b). The language of targeted investments is politically salient for the settler state because it allows the government to take credit for dedicating funding to certain social issues in Indigenous communities, while at the same time obscuring the denial of jurisdiction to Indigenous peoples. ${ }^{85}$

\footnotetext{
${ }^{85}$ Despite the emphasis on investment, the Harper government introduced an Omnibus Budget Bill in April 2012 that led to the closure and de-funding of numerous Indigenous organizations and programs. Notable cuts were made to the health portfolio (explored further in Chapter Five), which became the subject of several critical interventions by parties of the Indian Residential School Settlement Agreement.
} 
In a speech to The Canadian Club of Toronto in 2012, National Chief Atleo's previous slogan "smashing the status quo" 86 gave way to the "economics of reconciliation." He noted that "[t]he apology offered by Prime Minister Harper in 2008 and now the Truth and Reconciliation Commission add another cornerstone to our foundation of renewal. We must recall also that this period of reconciliation is about healing and recovery for all of us, not just First Nations" (Atleo 2012,3). This shared narrative of healing and reconciliation can be misread, as it implies that experiences such as residential schooling have been traumatic for both Indigenous peoples and settlers. It furthermore fails to acknowledge how settlers have in fact enjoyed great prosperity from these practices. Gathering Strength (1998) emphasized reconciliation over renewal as a means to rebuild and re-shape Indigenous-settler relations, and a consequence of this is the dilution of the concept of healing that featured prominently in RCAP recommendations. Healing is a particularly powerful concept that emerged from RCAP's Final Report (1996) and is integral to understanding Indigenous conceptualizations of a decolonized Canada. The Royal Commission on Aboriginal Peoples Final Report (1996) offers a decolonized definition of healing:

Healing, in Aboriginal terms, refers to personal and societal recovery from lasting effects of oppression and systemic racism experienced over generations. Many Aboriginal people are suffering not simply from specific diseases and social problems, but also from a depression of spirit resulting from 200 or more years of damage to their cultures, languages, identities and self-respect. (Vol. 3, 109)

This description of healing politicizes and historicizes the psychic ramifications of colonial oppression, instead of simply reducing Indigenous peoples to addiction or mental health statistics. Furthermore, RCAP's definition of healing represented a demand for material restitution in lieu of historical injustice by stating that "[t]here are other dimensions to healing, not least of which is the

\footnotetext{
86 "Smashing the Status Quo" was a campaign slogan that was utilized by National Chief Shawn Atleo of the Assembly of First Nations. Interestingly, this campaign slogan is a re-articulation of Zeebedee Nungak's slogan "constructive damage to the status quo," used during the Section 37 Constitutional Talks (See Canadian Arctic Resources Committee).
} 
role of non-Aboriginal Canadians in gaining greater knowledge and understanding of the history and aspirations of Aboriginal people and acknowledging the errors of the past. We are calling for restitution, in particular of a land and resource base" (RCAP 1996 Vol. 5, 63). The demand for the restitution of a land and resource base is particularly important to conceptualizing the relationship between healing and restitution.

During his address to the Canadian Club, Atleo stated that "[i]nvesting in our communities is a strategic, long term stimulus plan for all of Canada" (Atleo 2012, 6), and that "[o]ur economic visions are not dissimilar to the rest of Canada — we envision sustainable communities with healthy families as central to our overall success" (Atleo 2012, 5). He later re-states this position in an address to the Vancouver Board of Trade: "I have called clearly and consistently for the relationship to be fundamentally transformed, to be re-set and to once and for all begin taking decisive action towards reconciliation. This starts with dialogue and it requires the effort and commitment to build trust" (Atleo 2013,2). He goes on to say that

[t]his is about economic development on our terms. But those terms can be good for everyone. And certainly good for business. Economic development is one key to unleashing the full potential of First Nations citizens and communities in a way that benefits the country as a whole. By investing in our people through education, skills training and employment opportunities, we can take significant strides together securing enhanced employment and participation and supporting Canada's competitiveness and productivity. (Atleo 2013, 4)

Atleo repeatedly references the work of the Truth and Reconciliation Commission of Canada as a means to establish a frame of reference for the renewing of Indigenous-settler relationships. The benefits of reconciliation and economic development outlined by AANDC and the AFN may be used to quiet the voices of the grassroots movements. Self-determining Indigenous communities are viewed by the settler state as disruptive to practices of accumulation by dispossession, which have reached ascendancy in an era of neoliberalism. This practice "involves the dispossession of 
people from their wealth," whether this is in the form of natural resources, land or access to government finances (Gordon 2010,36) and is accomplished by situating Indigenous peoples as fundamentally dysfunctional is only one of them (see also Blackburn 2012; Million 2013).

At the Regina Chamber of Commerce in August 2012, then Aboriginal Affairs Minister John Duncan acknowledged a fast-growing Aboriginal population and noted "that there is an opportunity here that must be seized. Doing nothing will subject another generation of Aboriginals to lives of poverty and dependency, while seizing on the untapped potential of the young Aboriginal population will allow us to break the cycle of dependency and meet the labour needs of Saskatchewan and Canada" (Office of the Minister of Aboriginal Affairs 2012, n. pag.). In this quote, dependency is articulated as an "economic cost" to the state, and Aboriginal youth should be treated as a resource to be extracted to offset this expense. Later, at the Edmonton Chamber of Commerce in September 2012, Minister Duncan encouraged attendees to "help more Aboriginal people get fulfilling jobs and start meaningful careers" (Office of the Minister of Aboriginal Affairs 2012, n. pag.). Even at the 250 year celebration of the Royal Proclamation in October 2013, current Aboriginal Affairs Minister Bernard Valcourt stated:

Our goal is to move forward to find joint solutions that help reconcile relationships, promote self-sufficiency, and unlock economic opportunities for Aboriginal people and communities. While progress is being made, we know there is much work to be done and that requires commitment and cooperation on all sides. We all want results that make a real difference. (Office of the Minister of Aboriginal Affairs 2013, n. pag.)

Economic prosperity for Indigenous peoples is repeatedly framed as the core framework for a reconciled Canada, and frequently situated as a helping narrative with paternalistic overtones. At the core of economic development policies is also a desire to create mutual beneficiaries, primarily through the shared windfall of resource extraction and by the production of labour. 
The quotes above are illustrative of how a focus on harm and suffering constructs Indigenous communities as both economically and emotionally depressed in media and popular representations. There is a long history of pathology as endemic to Indigenous communities. Dian Million (2013) suggests that Indigenous experiences are often categorized through social science terms such as anomie (see Alfred 2009 b), however, this concept "allows an analysis of Indian malady without attributing it to any national Indian policy, the failed attempts at assimilation, economic isolation and residential schooling" (8). The categorization of Indigenous peoples as endemically pathological bodies and communities through reconciliation processes is in itself a violent practice. If suffering is posited as endemic to Indigenous culture, then liberal (and neoliberal) rationale to extend a deliberate and ongoing form of dependency is supported by settlerCanadians (see also Alfred 2009 b). Economic well-being is tantamount to Indigenous peoples' health being equated with increasing employability (Million 2011, 325-6). Pursuing "careers" is a meaningful outlet for Indigenous peoples, and according to the Conservative rationale will only lead to the development of more economic and employment opportunities.

The same rationale was taken up by The Public Policy Forum's 2012 Report, Building Authentic Partnerships: Aboriginal Participation in Major Resource Projects, which states that "the need to achieve greater social, economic, and health outcomes in many [Aboriginal] communities is undeniable. Often, these issues are closely related to the lack of trust stemming from historical abuses; resolving them requires that healing processes be respected and facilitated (10). Social change is conceived through the implementation of large scale economic development projects:

Development offers many of these communities the chance to improve local economic and social conditions. Projects can lead to jobs, updated critical community infrastructure, and better education and health systems. Closer involvement in development projects will allow communities to lead efforts for long-term sustainability through greater oversight. 
This is a once-in-a-generation opportunity to propel First Nations, Inuit and Métis communities into leadership positions in the resource sector and related businesses, while securing Canada's economic prosperity well into the future. (Public Policy Forum 2012, 8)

Assumptions that capitalist economic development and monies will generate "healing" solutions to the problems of colonialism persist and must be questioned alongside colonial history in Canada. What is increasingly important to understand about the imposition of a therapeutic model of reconciliation is its dual nature. The imposition of the therapeutic ensures that wrongdoing is presented as cultural as well as presenting capital accumulation and economic success as emancipatory (Million 2013; Vrasti 2013). In the case of Indigenous peoples, employment guarantees stability, health and a "normal" Canadian existence. Therapeutic aspects have the tendency to situate pain as an individual experience that is undergone during individual circumstances, therefore requiring individual redress.

In this section, I have examined how access to autonomous and self-determining opportunities for economic development have been advocated for by Indigenous peoples and organizations. These appeals are routinely directed at the corporate and public policy sectors. Yet, as I noted in Chapter Two, when these appeals are re-articulated by these sectors, there is undue attention paid to community dysfunction as well as the emancipatory aspects of wage labour. These imagined narratives of Indigenous dysfunction justify assimilationist interventions and undermine advocacy for Indigenous rights and jurisdiction. I argue that the conflation of economic development and reconciliation may not have originated with the compensation frameworks of the Alternative Dispute Resolution Mechanism or the Independent Assessment Process, but they both reflect the same assumptions about the legitimacy of capitalist and settler authority and the necessity for assimilation to "normalize" Indigenous subjects.

\section{Conclusion}


In this chapter I have explored how a therapeutic ethos and the law overlap to discipline compensation claimants as dysfunctional individuals in need of repair from the state. To begin, I contested Michael Bay and Stephen Winter's assertions that law and therapy are separate endeavours that rarely work in tandem. In contrast, I argue that the legal tort practices of categorization and quantification exact the influence of therapeutic ethos within the context of the Independent Assessment Process. Compensation in this context functions as a therapeutic investment for the settler state because the adjudicative process diagnoses Indigenous peoples with individualized and dysfunctional symptomologies that have prevented former students from working and contributing to Canadian society. While therapeutic jurisprudence is meant to help personalize adjudication and justice-seeking, the use of a point system is used to "account" for Indigenous peoples' suffering further engenders impersonal calculations to ensure transparent bookkeeping for the state.

In accounting for suffering through the Independent Assessment Process normal behaviours are conflated with employment and abnormal behaviours are equated with worklessness. This facile use of therapeutic intervention denies the well-documented structural obstacles that Indigenous peoples must face to find meaningful work. For this reason, demands for economic development gain renewed purchase in public discourse to the point where they become synonymous with the act of reconciling. By situating compensation within an investment frame, the act of reconciling is used to reproduce the coloniality of power by emphasizing the necessity of "health and self-esteem," and to reinforce settler assumptions that Indigenous peoples require intervention in their everyday lives. In narrowing the parameters of health and normalcy, Indigenous peoples' pursuits for self-determination and control over economic development on their territories is curtailed (see Blackburn 2012). 
While this chapter has examined how techniques of accounting and therapeutic categories have been used to discipline individuals through the compensation process, the following chapter examines the application of auditing and evaluation is used to discipline Indigenous health organizations and health support programming. Like Indigenous individuals within the compensatory framework, Indigenous organizations are subject to intense scrutiny and processural control through various audits. As a result, organizational autonomy and the pursuit of decolonial goals are routinely compromised by the imposition of settler law and public policy. 


\section{Chapter 5: Dwindling Investments: Disinvestment, Reconciliation and Health Supports Provision}

The warrior spirit is the strong medicine we need to cure the European disease. (Alfred 2009 b, 29)

I feel it is important that our visions of justice as healing be founded upon our knowledge and language, and rooted in our experiences and feelings of wrongs and indignation. These emotions cannot be avoided in constructing our vision of justice. Our visions of justice are to be based on Aboriginal knowledge about the nature of humans, their society, and our linguistic mode of understanding the ecology. We cannot simply borrow the Eurocentric versions of human nature or psychology or society, since they are not based on our wisdom, knowledge, or language. They have never known who we are. (Henderson and McCaslin 2005, 6)

In 2006, the Aboriginal Healing Foundation's original endowment of 350 million dollars

had been exhausted and a "winding down" phase of the organization had begun. The organization fought to extend their mandate to ensure that health supports were available for former residential school students during the implementation of the Indian Residential School Settlement Agreement. The Aboriginal Healing Foundation Final Report (2006) stated that the

fundamental argument in favour of [funding] renewal is the evidence of severe unmet healing needs that help to maintain disadvantage in physical and mental health, education and economic development. The legacy of residential school abuse lies at the heart of troubled family relationships and the breakdown of community support systems. In six years of reflective practice the AHF has enabled tens of thousands of Aboriginal people to break through their silence and isolation, to begin healing their memories and reaching out to reestablish emotional and spiritual connections. The healing work is well begun but much remains to be done. (Castellano Vol. 1 2006, 211)

Demonstrating the need for continued health supports, the organization proposed that an "Investment in Healing" was necessary because "predictable support for an average of 10 years in a given community or community of interest is required to reach a level of wellness where crisis services and community supports are available to sustain gains achieved" (Castellano Vol.1 2006, 213). To ensure that healing services could be extended to former students, the Aboriginal Healing Foundation stated that the "financial resources to undertake and fulfil the renewed mandate be set at the level of $\$ 600$ million and made available as a one-time grant to be invested as an endowment 
to generate income and be fully expended over a 30-year span" (Castellano Vol. 1 2006, 219). ${ }^{87}$ As I argued in Chapter Two, the Aboriginal Healing Foundation was routinely hamstrung by a limited mandate, but their programming was also limited by policy and investment procedures and practices that they were required to comply with (see Spear 2014). The Aboriginal Healing Foundation also argued that the mandate should be opened to the exploration of "the social, psychological and spiritual injuries, including intergenerational impacts" of the residential schools; they should "complement and advance the interrelated goals of acknowledgement, redress, healing and reconciliation"; which would allow funding to be extended to public education and research projects (Castellano Vol. 1 20016, 219). The "investment in healing” outlined by the Aboriginal Healing Foundation here demonstrates a twofold demand: firstly, for the expansion of the organization's mandate and secondly, for a greater funding endowment.

The Aboriginal Healing Foundation's investment proposal was not approved by the Government of Canada; however, 125 million dollars was transferred to the organization through the Indian Residential Schools Settlement Agreement in 2006 and the mandate was extended for another four years. This renewed funding was only short-lived since the Harper Government chose not to renew funding to the Aboriginal Healing Foundation in 2010. The disinvestment in the organization resulted in the immediate closure of 134 healing programs in March of that year and the official closure of the organization in 2014. This chapter asks: What does the tension between investment and disinvestment in the Aboriginal Healing Foundation reveal about the settler state's role in managing reconciliation initiatives?

This chapter interrogates the institutional scrutiny and threats of funding cuts faced by Indigenous organizations and explores the effectiveness of health support reparations when they

\footnotetext{
${ }^{87}$ Funding was needed to continue "outreach," "support for funded projects," "documentation and evaluation of
} effective healing practices," and to "support self-determination and self-reliance" (Castellano Vol. 1 2006, 215). 
are delivered under such strict programmatic and funding parameters. The literatures on auditing help to illustrate how organizational practices are routinely and frequently "checked" and "surveyed" to ensure accountability and transparency. I also question who accountability and transparency criteria are applied to and through what mechanisms is compliance with this criteria assured. While accountability is integral to the provision of health supports to former residential schools students, Michael Power (2000) has argued, extensive audits and evaluations are detrimental to certain programs and institutions because they are costly and are enacted to retain "control of [the institution's] control" (113). By this I mean that the "state's overt concern may be less day to day direction than to ensure that internal controls, in the form of monitoring techniques, are in place" (Strathern 2000, 3-4). I assert that restrictions on Indigenous organizations are primarily enacted to marginalize the role of Indigenous knowledge in the public sphere and to impede the realization of Indigenous jurisdiction in the delivery of services.

To elucidate the relationship between health support provision and government oversight, I also examine the trajectory of the Indian Residential Schools Resolution Health Support Program. Originally called the Indian Residential Schools Mental Health Support Program, the program was initiated by the First Nations and Inuit Health Branch of Health Canada to provide health support services to support former residential school students who were participating in the Alternative Dispute Resolution Mechanism. After the closure of the Aboriginal Healing Foundation, the only health support network offering services to former students was funded and managed by the Government of Canada. Making a comparison between the two health support programs, this chapter asks: what does the disinvestment in a voluntary sector program reveal about the mobilization of settler and neoliberal projects in an era of reparations? 
To differentiate between Health Canada and Aboriginal Healing Foundation programs, I draw on documents outlining national strategies, frameworks and organizations to understand how mental health programming is operationalized and implemented in Canada as part of the reconciliation process. In order to examine the two programs, I also conducted several interviews with healing program personnel to understand the dimensions and parameters of service provision as well as the consequences of healing programs cuts and closure. To support my analysis, I also examine documents obtained from an Access to Information request to assess how the federal government investigated the gap in health services after the closure of the Aboriginal Healing Foundation.

While the previous chapter explores how the law disciplines individual Indigenous claimants through legal categories and accounting processes, this chapter examines how organizations and programs that provide reparations to former residential school students are disciplined by settler law and public policy. Firstly, I illustrate the relationship between public health rationale and auditing techniques within the current climate of Indigenous health in Canada. Secondly, I describe the two health support programs that are used to support former residential school students: the Aboriginal Healing Foundation and Health Canada's Indian Residential Schools Resolution Health Support Program. In so doing, I outline the differing approaches to programming, governance structures of government and voluntary sector programs. Lastly, I document the Aboriginal Healing Foundation's record of exemplary evaluation and compliance while comparing the dearth of auditing practicing used by Health Canada to evaluate health support provision.

Health, Audits, and the Shadow State 
Building on the previous chapter, I examine how health values and outcomes are routinely situated within capitalist paradigms, and are therefore shaped to reflect these values. I examine differences in health paradigms to illustrate the different standards and approaches to health delivery in the public and voluntary sectors. I also situate health support provision within the context of the "new public management", which is a term that describes how the application of private sector ideals and values to the public sector (see Lane 2000), to consider how and why Indigenous knowledge is marginalized and Indigenous jurisdiction is questioned in the public sector programing (see also Abele 2007; Tomiak 2011).

Firstly, it is important to look at the differences between Indigenous and mainstream health values. The Public Health Agency of Canada deploys a population health paradigm to realize a vision that "aims to improve the health of the entire population and to reduce health inequities among population groups" (Public Health Agency of Canada 2012, n. pag.). This paradigm also

recognizes that health is a capacity or resource rather than a state, a definition which corresponds more to the notion of being able to pursue one's goals, to acquire skills and education, and to grow. This broader notion of health recognizes the range of social, economic and physical environmental factors that contribute to health. (Public Health Agency of Canada 2012, n. pag.)

While the population health paradigm is mobilized to "broaden" the definition of health from a medical lens to encompass socio-economic aspects of society, the main entry point for health under this rationale is individual responsibility and choice. Therefore, this paradigm "empowers" the individual to acquire one's own health in the pursuit of economic sustainability for the state. Coburn et al. (2003) suggest that "what emerges from population health models verges on trickledown theories of economic prosperity. Trickle-down theories assume that all we have to worry about is economic growth, and human health and well-being will automatically follow" (394). Therefore, under this paradigm mental health supports function as a way to strengthen the economy 
and engender a return for the settler state by way of the wage economy. In this regard, the population health model mirrors the rationale deployed in the compensation frameworks that imply that "normal" citizenship is defined by a subject's economic contribution.

The voluntary sector has recently began to use the language of investment to situate the need for mental health supports to solicit funding and support from elite powers. For example, in 2011 the Canadian Mental Health Commission of Canada deployed the following "Call to Action" in its much anticipated Mental Health Strategy:

Now is the time to invest more, and more efficiently, in mental health. Investing more in mental health and making use of current investments to achieve the changes described in this this strategy are the right things to do. Reversing the many years of under-resourcing of the mental health sector and making the mental health system more efficient will enable tens of thousands of people to improve the quality of their lives it will also contribute to the economic prosperity of the country and to the sustainability of the healthcare system. (124-5 emphasis mine)

The rationale of investment in Mental Health Commission of Canada's appeal demonstrates how the demand for much needed resources is deployed alongside a promise of economic prosperity as an outcome of improved mental health. In responding to this appeal, the government can recoup the costs of a public investment in mental health supports by minimizing dependence on social services. I examine the Mental Health Strategy here because this document underscores the dominant strategies and discourses that are employed by the mental health sector in Canada.

Indigenous conceptualizations of health reflect different values, pertaining to the health of an individual and in regards to health delivery. Indigenous health paradigms perceive "the physical, mental, emotional and spiritual aspects of a human being are all interrelated," and therefore "weakness in any of those areas causes a person to become unbalanced" (Robbins and Dewar 2011,3). An emphasis on interrelatedness can be useful in identifying the causes and 
impacts of ill health. For instance, former President of Pauktuutit Inuit Women's Association

Martha Flaherty, notes in Towards Reconciliation (1992):

Governments should abandon, once and for all, the idea that society's problems can be separated, categorized, and ordered...the overall health and well-being of our people is intrinsically tied to the social, political and economic development of our communities. We can no longer afford to pay the price of dividing issues into manageable portfolios, programs and services. A holistic integrated approach is necessary at every level and in relation to every issue or problem. (28)

The definition of health found in Towards Reconciliation (1992) confronts the impacts of compartmentalizing health from other social issues such as housing, economic development, and Indigenous self-determination. ${ }^{88}$ I suggest that a holistic approach to health is threatening to both settler and neoliberal projects because it undermines the conflation of individual health and economic contribution by drawing attention to the structural violence embedded within capitalist economies that produce the conditions for poor health outcomes.

The differing conceptualizations of health that I have outlined here are central to the governance of health delivery. The Government of Canada has established numerous ways of regulating health delivery primarily to ensure the so-called efficiency, transparency and accountability of health programs. However, in examining the regulations and standards that are applied to health support programming, it was not always clear if accountability is enacted to ensure the safety of program recipients or if it is accountability to the settler state that is predominantly sought. To help understand the politics of regulating organizations, I draw on

\footnotetext{
88 In 2007, the First Nations and Inuit Mental Wellness Advisory Committee was formed by members of the Assembly of First Nations, Inuit Tapariit Kanatami and the First Nations and Inuit Health Branch to develop a mental health strategy. A mental health framework, officially released 8 years later in 2015, advocated for a systems approach. This approach "to addressing care is inclusive of the full range of services, supports, and partners who have a role in addressing mental wellness issues among First Nations peoples. This includes, for example, First Nations community based services and supports but also related partners and jurisdictions (e.g. housing, education, employment and federal correctional services). It is recognized that no single sector or jurisdiction can support individuals and their families alone" (First Nations Mental Wellness Continuum Framework 2015, 20).
} 
auditing literatures (Power 1997; 2000; Shore and Wright 2008; Strathern 2000) to examine how accountability is enacted by state authorities. According to Shore and Wright (2000), the audit "is essentially a relationship between scrutinizer and observed: the latter are rendered objects of information, never subjects of communication" (59). The power to audit fundamentally remains with the settler state, while the experience of being audited is reflective of funded organizations and individuals. Auditing includes various techniques of "checking and verification" that Michael Power (1997) has ironically described as "sometimes burdensome, and always costly" (1). So, while auditing is designed to ensure a guard against waste and inefficiency, the imposition of auditing practices is relatively cost ineffective.

Scholars have also noted a contradiction in the rationale and application of audit culture, suggesting that audits that are supposedly designed to engender transparency and accountability may actually obscure more than they reveal (Power 1997, 8). To clarify this point, I deploy a caveat extended by Michael Herzfeld who suggests that the "state's evasion of accountability includes a call to account of those institutions which it funds" (quoted in Strathern 2000, 5). The evasion of state accountability should be problematized in the context of democratic governance, because under such a lens, individuals and organizations are required to be accountable while the state is increasingly required to be less accountable. In keeping with my analysis of therapeutic investment as an example of neoliberal and settler governmentality, I echo Shore and Wright's (1998) suggestion that "policies also have a legitimizing function. Not only do they outline the course of action to be taken, they also serve to fix that course within the framework of a wider and more universal set of goals and actions" (11). However, these actions may not in fact benefit the goals of recipient organizations and be used to discipline organizations. For instance, the 2011 Auditor General's Status Report on Programs for First Nations on Reserve outlines four structural 
impediments that compromise programs and services delivered in Indigenous communities, namely, a "lack of clarity about service levels, lack of legislative base, lack of appropriate funding mechanisms," and a "lack of organizations to support delivery" (8). Furthermore, a lack of consultation and communication between government officials and Indigenous service organizations in the context of programming and funding is also duly noted.

Similar misgivings about the excessive monitoring of Indigenous health programs were raised in the external evaluations of Indigenous health programs. Several health programs such as the National Native Alcohol and Drug Program and the Labrador Comprehensive Healing Strategy were evaluated by external consultants to see how public monies were being spent and if programs were benefitting their primary recipients. Many of these reports came to the same conclusion as the Auditor General. For instance, an external evaluation of National Native Alcohol and Drug Program suggested that programs "cannot continue to lurch from financial crisis to financial crisis. Decisions need to be made to ensure that the system of the future is able to plan and operate on a sound basis within funding parameters. To achieve this principle decisions will need to be taken that resolve program issues with the issues of cost" (Health Canada 1998, 9). These reports and evaluations document an ongoing disregard for community autonomy alongside extensive fiscal constraints. The resources available to these communities are still well below provincial averages in the mainstream healthcare system, leaving program delivery in Indigenous communities compromised by contractual restrictions. These reports envision accountability to Indigenous communities through the lens of extended community control over health programming and resources, as opposed to subsuming health under a national paradigm that emphasizes individual lifestyle choice. In the evaluation of the Labrador Comprehensive Healing Strategy sponsored by Indian Affairs and Northern Canada, "the [report's] findings suggest that 
healing is a long-term, on-going, holistic and collaborative process. The key concern with respect to the application of healing principles is how the federal partners operationalize the concept of 'community healing' and about whether the comprehensive nature and scope of healing is actually reflected in the funded healing initiatives" (Indian Affairs and Northern Development 2009, 8). The evaluations I address above are examples of progressive auditing techniques and can be useful in identifying risks to programs and health delivery for Indigenous peoples. Yet, the nation-state is not bound to adhere to the recommendations of these evaluations and the only power they hold is their position on the public record.

Health supports were designed to facilitate "healing" in Indigenous communities, whether it be in the form of counselling, addictions programs or group conversations. Health support provisions for former IRS students are primarily delivered through contribution agreements administered in either the public or voluntary sectors, otherwise known as the shadow state. ${ }^{89}$ Funding and institutional continuity is dependent on the compliance with policy criteria. Julie Tomiak (2011) suggests that current policy mechanisms governing the provision of services to Indigenous communities constitute a form of "government at a distance" that is "based on contractual funding relationships, accountability and reporting frameworks, and the continued fragmentation of policy and legal landscapes" (5). Contractual relationships are generally characterized by mistrust because

[f]rom the government perspective, the mistrust is based on having limited control over the provider while remaining accountable for the appropriate expenditure of public funding and the overall quality and effectiveness of the services delivered. From the provider's perspective, the mistrust come from a limited ability to influence and structure the contractual environment to access resources in a way that better fits the population served and services delivered. (Lavoie 2005, 11)

89 Defined more clearly, the shadow state is a "para-state apparatus comprised or multiple voluntary sector organizations, administered outside of traditional democratic politics and charged with major collective service responsibilities previously shouldered by the public sector, yet remaining in the purview of state control" (Jennifer Wolch quoted in Tomiak 2011, 55). 
These mechanisms are mobilized by the state to determine program outcomes and to ensure fewer expenditures for the state. Therefore, an investment in Indigenous mental health supports is constituted by both settler and neoliberal ideologies to the detriment of community authority and autonomy. Lavoie (2005) concludes her assessment of contracts by stating that "[a]lthough the Health Transfer Policy has created opportunities for self-administration, these opportunities have been limited to the administration and delivery of pre-existing services as determined by Health Canada" (21). These interventions call into question the potential for achieving reciprocal relationships through contractual health supports because investment is tied to settler ideologies that favour assimilationist and neoliberal rationale that ultimately benefit the state.

These constraints placed on community programs are primarily imposed through the use of funding contracts called contribution agreements enacted by Health Canada (Lavoie 2005, 11). These contracts govern investments made to Indigenous communities to support healthcare provision. The First Nations and Inuit Health Branch website states:

Through contribution agreements, the Government of Canada provides funding that must be spent according to agreed upon conditions. Spending is monitored and reviewed to ensure that these conditions are met. For many years Health Canada has provided direct health care services to First Nations and Inuit people of Canada. Beginning in the 1970s, government policies advocated more direct control by First Nations and Inuit communities of their own health services delivery. As a result, new health programs called for mechanisms to enable First Nations and Inuit communities to manage and control the delivery of health services to their members. (Health Canada 2012, n. pag.)

This statement equates contribution agreements to consensual partnerships designed to expand First Nations control over health services. However, the state's retention of control over programming can be read as way to contain and secure the settler state's investment in Indigenous health. Programmatic restraints can be read as a way in which public policy investments are rendered certain and determined to minimize risk. 
In contrast to contractual health support provision, not-for-profit sector organizations provide health support funding to Indigenous communities, particularly in the promotion of the healing movement. Scholarly approaches to neoliberalism suggest that under this economic system, the downloading of funding and responsibility to the voluntary and not-for-profit sector is a common state approach to effectively managing the cost of service provision (Larner 2000; Peck and Ticknell 2004; Tomiak 2011). In Canada, the creation of foundations and "arm's length organizations" reached ascendancy in the 1990s to help reduce the cost burdens of public sector service delivery. Wayne K. Spear (2014) notes that under the Chretien government, which lasted nearly a decade, the "use of shared governance corporations" functioned as "a favoured instrument...to achieve [the] government's policy objectives" (123). While still hamstrung by extensive accountability and reporting requirements, "a foundation may draw its operational funds as well as its project disbursements from the interest generated by an endowment, [and] it has the capacity to grow its initial government investment. A foundation may furthermore operate in perpetuity, without the need for additional investments [from the government]" (Spear 2014, 123). Therefore, to some degree there is more community autonomy at the community level when programs are funded through the voluntary sector.

Nonetheless, the shadow state or the not-for-profit sector has been theorized by several scholars as a representative example of co-opted community services that operationalize neoliberal logic at the community level (Wolch 1990; Gilmore 2007). Even as power is being extended to non-governmental actors, "governments rely upon hierarchical authority to implement their policies, and because even when the governments choose to govern in alternative ways, the state remains the pivotal player in establishing and operating governance strategies and partnerships" (Bell and Hindmoor 2010,3). Constraints placed on these organizations include the limitation of 
autonomous decision-making related to hiring processes, advocacy, and the parameters of eligible programming and funding criteria. Despite the popularity of arm's length organizations under the Liberal government, Spear $(2014,124)$ goes on to note that by 2005 , the Auditor General of Canada had deemed these foundations "untenable" in her annual reports. Her assertion was supported by two points:

The first was that the government funded arms-length foundation might weaken parliamentary accountability over the use of public funds. The second was that the manner in long-term visions and short-term politics which the government accounted for these expenditures did not reflect the real-time dispositions of public money. At the core of the Auditor General's critique was a technical argument about the ways in which government went about its bookkeeping. The report advocated strengthening the integration of delegated funding arrangements (such as foundations and crown corporations) into government departments and moving as soon as possible to accrual, or real-time, accounting. (Spear 2014, 124-5)

This quote demonstrates how the Auditor General sanctioned the government for counting nonfor-profit investments as a government investment. The question of real-time accounting is central to jurisdiction because it refers not only to what money is being spent on, but to who is deciding how the money is spent. ${ }^{90}$ Spear (2014) astutely points that the Auditor General's sanction against government downloading was interpreted by the media as a critique of the Foundation itself.

Differentiating between the shadow state and the public sector is an important consideration when analyzing the autonomy of Indigenous communities in designing and implementing health programming. I assert in this section that the provision of mental health supports to former IRS students incorporates a policy apparatus and methods of program delivery that are firmly embedded within the coloniality of power. In contrast to Health Canada driven health supports, the Aboriginal Healing Foundation funded a multitude of projects within its funding criteria, ensured programs with multi-year funding, and had fewer reporting criteria, all of

\footnotetext{
${ }^{90}$ Real-time accounting generally refers to up-to-date accounting that occurs on a daily basis as opposed to quarterly or annual reporting (see Trigo et al. 2014).
} 
which are suggestions that have been drawn from Indigenous health organization strategies (see AHF Program Handbook 1999; Castellano Vol 1 2006). While investments in health supports were meant to represent a commitment to reparative strategies and extension of jurisdiction, these investments enacted relationships that solidified state authority over program parameters (although to a lesser extent in the not-for-profit sector) and professionalized programs and initiatives that Indigenous communities had already created.

\section{Indigenous-Settler Relations: Mental Health Supports}

Western conceptualizations of health, such as the population health model, coincide with neoliberal rationale in dictating that it is an individual's personal and civic responsibility to be healthy. According to the population health paradigm, the "healthy" citizen utilizes far fewer social services and contributes to the economy more than what they extract from taxpayer funded programs. In contrast to this logic, a holistic approach to health would provide the means to deliver culturally appropriate services to a diversity of peoples, thereby supporting community autonomy and even working to extend jurisdiction to Indigenous peoples. Indigenous health paradigms and a social determinants of health model help to engender "some way of accounting for colonization as a crucial contributor to Indigenous people's present health statuses"; and is therefore more accountable because "[f]or Aboriginal peoples, colonialism is considered a social determinant of health" (Nelson 2012, 1). This section examines two national programs that deliver mental health supports to Indigenous communities as part of the ongoing process of Indigenous-settler reconciliation, and have been at the forefront of delivering mental health supports: the Aboriginal Healing Foundation, created in 1998, and the Indian Residential Schools Resolution Health Support Program (formerly the Indian Residential Schools Mental Health Framework) created in 2002. 
Several organizations have documented the ongoing needs of mental health and addictions support for Indigenous communities, in particular, shortages of mental health supports were identified at the Special Chiefs Assembly in 2010 (see Assembly of First Nations 2011) and by the Truth and Reconciliation Commission of Canada's Interim Report (2012). In order for reconciliation processes to be accountable to Indigenous peoples, the reports stipulated that the mental health of former residential school students and their families needed to be a priority. Instead, as I will demonstrate in the following sections attempts to remain accountable to former students were hamstrung at the organizational level due to settler state control imposed on the health support programs by the nation-state.

\section{The Aboriginal Healing Foundation}

As I noted in Chapters Two and Three, the Aboriginal Healing Foundation was designed to provide funding to Indigenous communities engaged in healing projects. Few scholars have examined Aboriginal Healing Foundation programs but where they have been examined, analyses generally fall into two categories. The first set of scholarship celebrates the novelty, ingenuity and necessity of the organization and its programming (see Castellano 2010; Robbins and Dewar 2011; Degagne 2008; Spear 2014; Wadden 2009), most often written by former employees of the Foundation. Other scholarship seeks to examine the therapeutic aspects of the organization's programs as well as their vulnerability for co-optation by neoliberal rationale (see Green 2012; Million 2013; Molema 2011). My analysis cuts both way, in that I acknowledge the organization's problematic deployment of neoliberal and therapeutic rationale in its programs, but I also believe that the organization offered an important model for Indigenous organizations operating at the national level in its strategic resistance to settler state authority. 
The Aboriginal Healing Foundation advanced a holistic approach to health by focusing on the Ojibway Medicine Wheel, "which describes the separate dimensions of the self-mental, physical, emotional, and spiritual —as equal and as parts of a larger whole" in order to outline the epistemology of its healing programs (McCormick 2009, 338). The emphasis on histories of violence of residential schooling as well as its intergenerational legacy coincides with an Indigenous approach to health. Stated more clearly, the role of colonization in producing and reproducing trauma amongst Indigenous peoples was a central component to the organization's approach to programming. According to the Aboriginal Healing Foundation Evaluation, "[t]he most frequently used interventions to support personal healing were: healing/talking circles, Legacy education, workshops and ceremonies" (Castellano 2010, 23). Also important was an emphasis on community programming that encouraged "residential school survivors to become 'Survivors as Healers,' who are then capacitated to share healing remedies with other survivors, or to help people who are intergenerationally impacted by the legacy of residential schools within their own families and communities" (Molema 2011, 5-6). The importance of Survivors helping Survivors was emphasized to strengthen the community from within, as opposed to relying on outside "experts" that could impose or specific healing programs that lacked appropriate cultural practices or approaches to cultural safety. To build on this idea of community autonomy, I cite a voluntary sector employee at length:

It is really a question of the value of being able to solve problems on your own. If I were to say to you, ask you to solve a problem and gave you the resources to solve that problem. Said that you could come up with [the solutions], there are some restrictions on how you solve this problem, but you can come up with your own ways of doing it and solve it on your own and take full credit or full blame with whatever the outcome is. That is suddenly in your hands. If, however, the same problem existed and I gave the money to someone else, maybe your parents, and asked them to hire you to implement their solution....well, right away you can see the difference in those two things. (Voluntary Health Sector interviewee, 2011) 
The question of value in this quote is particularly important with reference to governance and community autonomy, but it is also important in terms of access to resources because it gestures to the organization's interest in bolstering community decision-making, which is a central component in extending jurisdiction.

Indigenous communities healing interventions are not new or uncommon. Healing projects have been organized ad hoc or in partnership for several decades without the need for government intervention. Dian Million (2009) notes that "[a] range of therapeutic interventions had grown in the Indian communities over the 1970s; Alcoholics Anonymous, along with community health discussions on alcohol abuse and incest in rural areas, offered individuals new possibilities and language to narrate life experience" (56). In battling addictions, Indigenous communities' development and use of non-state funded programs has yielded impressive results. For instance, Arie Molema (2011) notes that "Alkali Lake, a Secwepemc First Nation in British Columbia, developed a successful and widely emulated treatment program for alcohol abuse, pairing rehabilitation and cultural rediscovery and popularizing the notion that 'culture is treatment.' Twenty years later, the funded projects of the Aboriginal Healing Foundation built upon the understanding that "culture is good medicine"” (2). Therefore, community health supports and community health programming were not invented with the creation of the Aboriginal Healing Foundation. The AHF's programs were designed to increase the potential for Indigenous communities to create autonomous programming.

The popularity of healing circles or therapeutic counselling interventions did not dissuade communities from establishing different approaches that privileged community selfdetermination. Marlene Brant Castellano (2010) states that for First Nations communities,

recovering their language was a profoundly healing experience....For Inuit, going out on the land and engaging in traditional survival and harvesting activities was often key to 
healing. In Métis projects people researched their history and found that making contact with their relations was transforming. (26) ${ }^{91}$

Therefore, cultural revitalization was a central component to health support provision in community programs. The emphasis on community participation in many AHF programs is an important contradistinction to government programs because "one-on-one therapies by mental health professionals are by themselves inadequate to respond to the pervasiveness and trauma that continues to reverberate in Aboriginal communities" (Castellano 2010, 27). The Aboriginal Healing Foundation also funded creative programming which initiated art projects and land-based programming. Moreover, the specificity of language and cultural loss cannot be fully encapsulated through either a psychotherapeutic perspective or solely through individual interventions. There needs to be a systemic component to understanding and confronting how this type of loss determines the collective health of Indigenous peoples. One way in which the organization approached a systemic critique was through the creation of a robust research framework (Voluntary Health Sector interviewee). The Aboriginal Healing Foundation created a substantive archive of public documents regarding the experiences of trauma, healing and best practices. The organization also researched the experiences of receiving reparations and generated several edited volumes on reconciliation that contained contributions by academics, leaders and practitioners. While the research strategy was very successful, it was limited by policy guidelines that limited voluntary organization's capacity for advocacy. ${ }^{92}$

\footnotetext{
${ }^{91}$ Program descriptions for all funded programs can be found online at the AHF website, and the feedback received from these projects can be found in the three-volume Evaluation that was conducted by AHF staff during the initial wind-down time in 2006. Transparency and Accountability were central to the governance of the Aboriginal Healing Foundation and even in 2014, four year after its closure, all publications and reports are available online.

92 The Canada Revenue Agency enforces the "10\% rule" which means that only this percentage of organizational funds can be spent on advocacy projects and strategies (Calgary Chamber of Voluntary Organizations 2012, n. pag.).
} 
The Aboriginal Healing Foundation was first and foremost an organization that provides funding to communities to support their own programming. Community autonomy and accountability was prized by the Aboriginal Healing Foundation and was an organizing component of the application for funding which was originally extended to communities (Aboriginal Healing Foundation 1999, 7). In applying for funding, the language of accountability to community members was privileged. The application form states that "accountability refers to the kinds of reports, information, meetings, updates and other kinds of communication you will use to be accountable to these 3 groups (referring to other organizational linkages) ${ }^{93}$ In other words: What information will you share? When will you share it? How will you share it?" (Aboriginal Healing Foundation 1999, 7). The form also asks the applicant to describe how the project will be accountable to "people who have survived the residential school system; the community where the project will take place; and the target group who will benefit from the project" (Aboriginal Healing Foundation 1999, 7). Applications without at least three letters of support from residential school survivors are considered incomplete, and the application form demands that letters should describe "how each survivor will be involved in the project, how each survivor will benefit from the project, and the name of the Survivor and residential school attended" (Aboriginal Healing Foundation 1999, 7). I draw attention to the description of accountability in this application form because it is directed at the recipients and partners of the program, as opposed to demanding how the programs is going to be held accountable to its funders. The Aboriginal Healing Foundation required far less reporting (annual reports only) and negotiated many multi-year funding agreements to recipient communities. This is fundamentally different to the funding approaches utilized by Health Canada programs, which I will examine in the following section.

\footnotetext{
${ }^{93}$ Under Linkages, applicants are asked to "Please list the organizations, agencies, services or communities your proposed project will link with (AHF Program Handbook 1999, 7).
} 
The politics of investment is crucial to understanding to accountability and transparency in the provision of health supports to former residential school students. While the Aboriginal Healing Foundation needed to be accountable to recipients, they also needed to be accountable to the state. In this book, Full Circle: The Aboriginal Healing Foundation and The Unfinished Work of Hope, Healing and Reconciliation $(2014,75)$, Wayne K. Spear notes that, from the original contribution agreement, the Government of Canada imposed prohibitive restrictions on Aboriginal Healing Foundation investments. Stated more clearly, the original endowment of 350 million dollars that was received by the Aboriginal Healing Foundation was intended to run the organization and fund healing programs in community for approximately 10 years. Yet, in order to ensure the longevity of the programs, the endowment required investments to grow capital to support the administrative organization. He goes on to suggest that the 350 million dollar endowment that was received only allowed the organization to invest in

banker's acceptances, bank certificates of deposit, commercial paper, bonds and notesissued and guaranteed by the federal government, provincial governments, territorial governments, municipal governments and corporations-government and corporate strip bonds, deposits at deposit-taking institutions in Canada, the commercial paper or shortterm securities which have a credit rating of at least aa, asset-backed securities, and collateralized mortgage obligations, with a maximum remaining term to maturity of eight years. (Spear 2014, 75)

These limits on the investment policy were imposed due to the risk of funding loss. Also, there was a fear that the investments would be mismanaged and that the endowment would be squandered through bad decisions or economic downturns. This fear played into the settler assumptions about Indigenous peoples' dysfunction and inability to govern themselves that are so prevalent in discourses of victimhood (see Blackburn 2012). Mike DeGagne, former Executive Director of the Aboriginal Healing Program, was perturbed by the lack of investment opportunities to ensure the sustainability of the organization and the healing programs: 
Growing the money and changing the [investment] conditions of the money was a key question in my interview when I was hired. So within a month of my hiring I had talked to some people from the Privy Council Office, and when I asked them about this they said, "This is not going to go anywhere. We are not prepared to give you that much autonomy. To be frank, we'll be grateful if you just don't run off with the money." It was like they were worried we'd become some sort of political pain in the ass, so there had to be a leash there that we would always feel. (Spear 2014, 76)

I use this quote to contextualize how shadow state investments are governed. At the same time, the quote is important for contextualizing investment rationale writ large, because the assumption is that it is the investor who has autonomy and the ability to make decisions. However, in this case study, the Aboriginal Healing Foundation is treated like the investee and the settler state remains the investor since they were the provider of the original endowment. The control over how the endowment is managed occurs at a distance through a series of policy initiatives. Despite the restrictions imposed on the Aboriginal Healing Foundation, "over 107 million dollars would be yielded from investments, enough to pay administration costs and commit over 10 million dollars beyond what was provided by government to the AHF”' (Spear 2014, 75). This means that nearly all the endowment was used to fund the healing programs and operational costs were covered by the interest. However, as Spear $(2014,77-8)$ argues most persuasively, with a less conservative investment agreement, the Aboriginal Healing Foundation may have been able to extend its operations for a much longer time period. ${ }^{94}$

The politics of investment do not end here, since the Aboriginal Healing Foundation was not simply an investee, but its role as a funding body also made it an investor. Spear notes that the Aboriginal Healing Foundation employees and board members were excited by the prospect of receiving such a large endowment from the government, yet after the first round of proposals,

\footnotetext{
${ }^{94}$ The Funding Agreement that was originally created between the Government of Canada and the Aboriginal Healing Foundation was enshrined in the Indian Residential School Settlement Agreement as 'Schedule M' (see Indian Residential Schools Settlement Agreement 2006 b, n.pag.).
} 
approximately 1 billion dollars had been requested from Indigenous communities and the amount of money provided to fill this need was not available (Spear 2014, 99). This overwhelming need and demand for resources is indicative of the ongoing structural violence inflicted against Indigenous peoples during the late $90 \mathrm{~s}$, the poverty of public investment, and government inaction in addressing these needs.

The politics of investment, however, do not flow only one way. The Aboriginal Healing Foundation was forced to make tough decisions of their own. Former board member Kitstabish remembers the difficulty in deciding which community projects would receive funding and which ones did not. I quote him at length to demonstrate the complicated nature of providing funds:

These moments were painful. These painful moments lasted throughout a couple of years, up until reason took over. You know, the way we accepted the decision, the formula we agreed upon, one needed to understand it, to dissect it, to explain it. And that's how I was able to survive that period. Talking to administrators, accountants - accountants have no heart. Finance people have no heart, no feelings, nothing. They are cold. They explain things straight, direct, like a surgeon. When a surgeon discovers cancer, there is no fooling around on his part. He says, "I operate, take it out, and you have no chance to survive even if I do it in 30 seconds." When my wife got her diagnosis on July 7, 1997, the surgeon told her, "We can't operate the type of cancer you have. Your cancer has spread about 75\%. You have a brain lesion. We'll do radiation treatment on the brain lesion, but for the rest, we can't do anything, it's terminal." Your life in thirty-five seconds. How about that, eh! A hell of a thing. I had the same feeling, so I took the position of the surgeon and the finance people to tell people "that's how it is." Try saying that with no feelings, heartlessly. Well, it had to be done, so I did it. And I was happy after a few years, happy for the experience. It made me take tougher stands, hardened my heart, but it increased my capacity to approach things on a more intellectual, rational basis, to reason things out looking for solutions. (quoted in Spear 2014, 99)

In this quote, I draw attention to how the investor, the accountant and the surgeon are characterized by their lack of emotion, which speaks to a form of governance with is depersonalized that seemingly contradicts an organizational mandate highlighting community programming. Moreover, I am interested in how the speaker's "hardened heart" was deemed beneficial to the future tasks of "governing." 
In recent years health support programming, including that of the Aboriginal Healing Foundation, has been theorized through the lens of biopolitics (see Million 2013; Molema 2012) to demonstrate how healing programs represent a form of governance where lives are produced according to a particular set of values (see Million 2013, 148). The rationale of healing defined by the Aboriginal Healing Foundation is generally enunciated from "a huge litany of familiar symptoms, which alcohol and sexual abuse lead [sic] to the now also familiar diagnosis of trauma" (Million 2013, 148). Million suggests that while trauma exists in these communities, the emphasis on trauma and healing encourages participation in government programs that emphasize the emancipatory outcomes of the wage economy and economic development projects. These healing programs are theorized as an exercise in "self-management," where Indigenous peoples are "compelled to heal" for reconciliatory purposes such as economically enhanced communities and national well-being. This is a noteworthy argument that is central to my overall analysis, but I also take into account Julie Tomiak's $(2011,55)$ analysis of the urban Indigenous voluntary sector by questioning the premise of the complete co-optation of Indigenous health supports. I argue that limitations imposed on government endowments and funding have also ushered a neoliberal ideology into the programming. Nonetheless, the Indigenous voluntary sector has managed to assert autonomy and jurisdiction despite the constraints placed on their programming. In addressing the role of urban Indigenous organizations, Tomiak (2011) argues that

the Indigenous voluntary sector should not be seen as fully incorporated in the neoliberal model insofar as pursuing the mandates of Indigenous organizations under conditions of neoliberalism does not inevitably entail co-optation. To some extent, neoliberalization has created the conditions that have allowed for collective action in urban settings and challenges to settler state hegemony based on Indigenous rights. In other words, the downloading of programs and services and the responsibilization of urban Indigenous organizations has increased the capacity of urban Indigenous communities to constitute spaces and pursue strategies beyond the confines of neoliberal prescriptions. (55) 
While Tomiak address urban governance, I believe her analysis also applies to the Aboriginal Healing Foundation in that this organization challenged settler state approaches to programming by supporting community based healing programs that foreground Indigenous health paradigms and recipient accountability as opposed to simply imposing programmatic accountability on communities. Nonetheless, I acknowledge that the organization was disciplined by public policy and the legal parameters of the IRSSA, especially in limiting investment options that would have ensured the continuity of the organization's funding. Therefore, the fate of health support programming always ultimately remained in the hands of the state because the capacity to invest was curtailed. Despite the Aboriginal Healing Foundation's limited mandate to create diverse healing programs and an extended public research portfolio being undercut by limitations of advocacy, the Aboriginal Healing Foundation did feature programs that emphasized arts therapy, land-based healing and research based healing projects that incorporated far more Indigenouscentered programming than the programs that are enacted through Health Canada.

\section{The Indian Residential Schools Resolution Health Support Program}

The First Nations and Inuit Health Branch of Health Canada operates as a funding and service provider to Indigenous communities. This department is also responsible for shaping public policy related to Indigenous health and mental health through the implementation of national health "initiatives." ${ }^{95}$ One of the first mental health strategies deployed in Indigenous communities by Health Canada's mental health was the National Native Alcohol and Drug Abuse Program

\footnotetext{
${ }^{95}$ It should be noted that my reference to national here refers to the nation-state as opposed to the constitutional nation-to-nation relationship that I have advocated throughout this dissertation. The emphasis on national programming in this context requires problematisation because of the varied approaches to mental health amongst Indigenous communities in Canada.
} 
(NNADAP) ${ }^{96}$ This program, created in 1981, oversees both residential treatment facilities and community-based programs that are governed by contribution agreements between the Health Canada and local service providers. Mental health and healing programs were generally subsumed under the addictions intervention umbrella until the creation of the Indian Residential Schools Mental Health Framework in 2002. Framing the issue in this way, individual lifestyle choice, as opposed to structural problems such as oppression and marginalization, are assumed to be the cause of mental health problems in Indigenous communities (see also de Leeuw et al. 2010). Following an external evaluation of the NNADAP program (Health Canada 1998) -which provided 37 recommendations about how to improve these services - programs dedicated to other health issues such as residential school mental health, suicide prevention and maternal/child health began to emerge. ${ }^{97}$

Healthcare provision in Indigenous communities is often referred to as the fourth sector, which means that the services provided to Indigenous communities are constituted as external to the three main health sectors which have been identified by scholars and practitioners as: government, not-for-profit and non-governmental service providers. The fourth sector is governed by the 1979 Indian Health Policy and by the 1986 Health Transfer Policy, both of which were designed to highlight a commitment by the settler state to implement further control over healthcare in Indigenous communities. Despite its commitment to extending Indigenous jurisdiction in health portfolios, the Romanow Report (2003) described the fourth sector as "a confusing mix of federal, provincial and territorial programs and services as well as services

\footnotetext{
96 This program is still considered a mainstay in the mental health programming in Health Canada and should not be confused with the National Native Addictions Partnership Foundation (NNAPF), a national advocacy group funded by Health Canada and Aboriginal Affairs and Northern Development Canada.

${ }^{97}$ Some of these programs include: Brighter Futures, Building Healthy Communities, National Youth Solvent Abuse Program.
} 
provided directly by some Aboriginal communities" (Ashton and Duffie-Ashton 2008, 53). This jurisdictional quagmire complicates the transfer of authority to Indigenous peoples because different sectors impose different constraints on healthcare provision. Moreover, the fourth sector has become a site where settler governmentality is operationalized through jurisdictional control. Decision-making authority is retained by the nation-state despite the extension of funding for “community programming."

The Indian Residential Schools Resolution Health Support program is the primary public sector health support program for Indian residential School survivors. Originally entitled, the Indian Residential Schools Mental Health Framework, this framework was designed to support "claimants" who were participating in the government sponsored Alternative Dispute Resolution program. The IRS Mental Health Framework (2004) stated that "Canada has heard from many former students, their families and communities that disclosures of abuse are often emotionally traumatic, and as such mental health supports should be made available and accessible for all those IRS students who are actively resolving their IRS legal claim (hereafter referred to as "claimants"” (Health Canada 2004 a 1, emphasis mine). Health supports were available to ADR claimants during the process; however, these health supports were not easily accessed by all claimants, as health support practitioners were relatively few and the process was drawn out over many months.

Not unlike the Alternative Dispute Resolution process itself, the Indian Residential Schools Mental Health Program was critiqued by Indigenous peoples for its lack of accountability to former students participating in the compensation process. A government representative stated that three main changes were made to the program after the settlement of the Indian Residential Schools Settlement Agreement in 2006: a) the program name changed to the Indian Residential Schools Resolution Health Support Program, b) changes were made to eligibility standards, and c) the 
implementation of a cultural support component (Government of Canada Interviewee March 2011). For instance, the current iteration of this program opened services not only to former students, compensation claimants and those participating in the Truth and Reconciliation Commission, but also to their immediate family members. From its inception, the program's attention to those "actively resolving" their reparations and healing processes should be read as problematic given that this program is only open to those former students who voluntarily participate in the official reconciliation process administered by the Indian Residential Schools Settlement Agreement. This program also excludes those who did not attend an institution that appears on the Official Schools list (Independent Assessment Adjudication Secretariat 2011, 404), with the stipulation that only those who are healing through a government endorsed program have a legitimate claim and access to supports. Government sponsored health support programs function to contain the number of people who can access health support program, and due to the influence of a population health model, the preferred outcome of health supports is wage employment.

The Indian Residential Schools Resolution Health Support Program (IRSRHSP) combines numerous programs and services. According to the Assembly of First Nations, the IRSRHSP program is designed

to help former students and their family safely through issues related to the Indian residential schools as well as the disclosure of abuse during the Settlement Agreement. Subsumed under the health support framework for the Indigenous-settler reconciliation process is a $24 \mathrm{hr}$ telephone crisis hotline which is available to those experiencing immediate crisis. In accessing these services Health Canada "coordinates and funds" the following services: "individual and family counseling; emotional support; cultural support; and assistance with the cost of transportation." (Assembly of First Nations Mental Health Addictions IRS Update 2009, n. pag.)

Former students and potential clients were encouraged to contact Health Canada Regional Offices by phone in order to find the closest support available to them, or to contact the Emergency health 
line to recommend immediate services. ${ }^{98}$ The services provided by this program are primarily limited to one-on-one counselling, event and process support and the emergency hotline. This means that the resources and services available to former students are directed towards individuals and are applied to all Indigenous communities through a universal/homogenous model.

Claimants of the Indian Residential Schools Resolution Health Support Program can access support from one of three different types of service providers: Resolution Health Support Workers, Professional Counselling and Cultural Support. ${ }^{99}$ Emotional support is provided by Resolution Health Support Workers "to help former students and their families safely address issues related to the negative impacts of the Indian Residential Schools as well as the disclosure of abuse during the Settlement Agreement process" (Health Canada 2013, n. pag.). Primarily, emotional support is provided at events or during compensation processes, and can be accessed by clients as followup sessions if support workers are available directly in the community. The Resolution Support worker may travel to various communities should funding support from federal government programs and their organization of employment be made available.

The Indian Residential School Resolution Health Support Program also provides a professional counselling option that allows former students to seek the help of "psychologists and other mental health professionals (i.e. social workers) that are registered with Health Canada and have experience working with Aboriginal people. A professional counsellor will talk, listen, assist individuals to find way of healing from IRS experiences" (Health Canada 2013, n.pag.). ${ }^{100}$ A travel

\footnotetext{
${ }^{98}$ Health Canada currently has an Atlantic Region office, as well as one for Ontario, the North, Quebec, Manitoba, Saskatchewan, Alberta and British Columbia.

${ }_{99}$ Originally, the Indian Residential Schools Mental Health Framework on offered on the two former services, and the latter form of support was added after the implementation of the IRSSA.

${ }^{100}$ It should be noted that qualification for professional counselling is based on professionalization. These standards have been carried over by the Indian Residential School Mental Health Framework. Qualification includes: Registration as a psychologist in the province/territory in which service is being provided with clinical or counselling orientation; Registration as a social worker in the province/territory in which service is being provided (MSW or PhD
} 
grant is also available to claimants where services may not exist in their community. This program emphasizes culturally sensitive one-on-one or small group counselling because service providers generally rely on psychotherapeutic approaches to healing, and health practitioners are required to be a member of a mainstream professional association. Therefore, familiarization with Indigenous mental health practice is part of a practitioner's "expertise" and does not necessarily meet the criteria of "cultural safety" where community specific practices are employed to ensure accountability to Indigenous claimants (see Adelson 2000; Gone 2010).

Since the need for cultural sensitivity and cultural safety has been thoroughly documented by Health Canada (see Health Canada 2015), a new type of support was introduced to the Indian Residential School Resolution Health Support program after the IRSSA was negotiated. Cultural Support, usually conducted or overseen by Elders or "traditional healers," is "determined by the needs of the individual and includes dialogue, ceremonies, prayers, or traditional healing" (Health Canada 2013, n.pag.). ${ }^{101}$ A representative from the voluntary sector noted why cultural support was important, since health support practitioners

have to be trained, this is almost always by a Western person, approved psychologist or approved social worker. That is fine, but there aren't many of them...they don't have a way of conceiving traditional education, and how elders are recognized in the community and how their ability and talents can be recognized, and that is where you get the financial compensation disparity. (Voluntary health sector interviewee January 2011)

The interviewee not only notes that training marginalizes Indigenous worldviews in the provision of health supports under the government model, but also indicates that these support workers do not obtain the same respect or financial compensation that is provided to a professional counselor.

\footnotetext{
in social work with clinical orientation); and a member in good standing with his/her provincial/territorial College of Association (Health Canada 2004 a, 9-10).

101 In an email I received from Health Canada on October 24, 2012, concerning accurate and updated numbers of IRS RHSP services providers, there was a stipulation that stated "Resolution Health Support Workers (RHSWs) and Cultural Support Providers (CSPs) are not employees of Health Canada, but are employed by community-based Aboriginal organizations."
} 
The Indian Residential Schools Resolution Health Support Program is operated in a similar way to the Aboriginal Healing Foundation programs. The government provides funds to community organizations to mobilize the provision of health supports for former residential school students (and their families) in a particular community. Not unlike the Aboriginal Healing Foundation, the government of Canada uses a contribution agreement to outline the requirements that program administrators are required to fill. The Recipient Guide to Health CanadaContribution Agreements defines a contribution in this way:

A contribution is a conditional transfer of funds to an individual, organization or other level of government to reimburse some portion of the costs incurred in carrying out a worthy project that the Government of Canada wishes to support: The conditions of payment are specified in a Contribution Agreement; The recipient must account for the use of funds and report on results attained from their use; The contribution is subject to being accounted for and audited. (Health Canada 2004 b, n. pag.)

By entering into an agreement with Health Canada, organizations must provide a "description of the project's objectives, measurable results, activities and timelines; the project budget, including a cash flow forecast" (Health Canada 2004 b, n. pag.). Tips for ensuring that your project is wellmanaged include: "have a competent manager and bookkeeper, establish strong internal management systems and procedures, provide leadership and promote team work, develop a strategy for managing change, establish a mechanism for resolving disputes and know where you stand with your partners, choose consultants carefully, communicate about what you are doing and closing out the project" (Health Canada 2004 b, n. pag.). While my comparison of the application form for funding and the actual contribution agreement may not be accurate, the differences in audience and language draw attention to the threat of risk associated with applying to Health Canada programs. The list of "tips" to ensure that the project is well-managed illustrates a desire to eliminate risk through the establishment of particular mechanisms. 
In this section, I have outlined the type of programming provided by two national healing strategies, one administered by the public health sector and one administered by the voluntary health sector. Both programs have approached healing supports in paradigmatically different ways: the Aboriginal Healing Foundation privileges community projects that address the health impacts of colonization on Indigenous peoples, while government programs privilege psychotherapeutic interventions that rely on individual assessment and counselling. The community-oriented focus of the Aboriginal Healing Foundation has left programming open to the majority of community members and does not discriminate on the basis of eligibility criteria like the Indian Residential School Health Support Program does. This means that First Nations, Inuit and Métis communities have had access to resources that have been denied through the Indian Residential Schools Settlement Agreement, and, in some Métis communities, these healing projects may have been the only type of reparation they received from the Government of Canada. As I note above, accountability to Indigenous communities and former students of the residential school system is emphasized far more in Aboriginal Healing Foundation projects. While Health Canada emphasizes the importance of incorporating Indigenous practitioners and ensuring cultural safety for clients, these programs also privilege a population health paradigm that employs psychotherapeutic paradigms and a medicalized diagnostic. The accountability criteria for these programs also emphasizes compliance to contribution agreements that are primarily deployed to minimize risk to the settler state.

\section{Analyzing Disinvestment}

In March 2010, the federal government announced that the Aboriginal Healing Foundation would not receive a replenishment of funding in the upcoming federal budget, and the 125 million dollars received as part of the Indian Residential Schools Settlement Agreement was to be the final 
investment that the organization received. When the funding cuts to the Aboriginal Health Foundation were announced, many Indigenous organizations contested the closure of the institution. For instance, on September 28, 2010 a Standing Senate Committee on Aboriginal Peoples meeting was held on Parliament Hill to address "the progress made on the commitments endorsed by parliamentarians of both chambers since the government's apology to former students of Indian residential schools" (Standing Senate Proceedings 2010, n. pag.). Witness Charlene Belleau, Manager of the Residential Schools Unit at the Assembly of First Nations, stated:

Funding cuts have left a void that is not being fully addressed by Health Canada. Health Canada received $\$ 95$ million over six years [to administer the IRSRHSP]. They were over budget by the time the allocation of $\$ 65.9$ million was made in the 2010-11 budget for a two-year timeframe. Again, that is inadequate to meet the needs of the former students and their families. Health supports are critical to the IAP, TRC and commemoration processes. (Standing Senate Proceedings 2010, no pag.)

Belleau was a witness for the Standing Senate Committee's review of Canada's commitment to the 2008 apology to former residential school students. The lack of health supports was the central to commentary on the AHF's closure. In February of 2012, the Truth and Reconciliation Commission's Interim Report (2012) reiterated the same notion of shortage in regards to health support provision. The Report states:

Survivors have told the Commission repeatedly of their urgent need for specialized health supports available near where they live. This need is especially acute in the northern and more isolated regions of Canada. In those regions, the per-capita number of residential school survivors and the critical need for health support are higher than in the rest of the country. (Truth and Reconciliation Commission of Canada 2012, 8)

By emphasizing the need for health supports, supporters of the Aboriginal Healing Foundation used discourses of need to shame the Harper government into reconsidering their decision to cut funds to the organization.

Supporters and detractors of the organization participated in a lengthy Emergency Debate in the House of Commons (March $30^{\text {th }}, 2010$ ) that focused the closure of the Aboriginal Healing 
Foundation. Many Liberal and NDP members supported the continuation of funding based on the "quality of programming" and the use of Indigenous healing paradigms to facilitate programming. MP Carol Hughes made perhaps the most controversial comment by drawing a correlation between health support availability and the policies that governed residential schooling:

The hon. minister said that the Conservatives were willing to provide services to aboriginal people [sic] in their communities, and if this is not possible, they would be willing to pay for those people to travel. Once again, we see that the government wants to take these individuals out of their communities and provide services elsewhere. Yet that is exactly what happened with residential schools. They took aboriginal [sic] people out of their communities and that is not what they want. Aboriginal people want to receive services in their communities. (Proceedings Parliament of Canada 2010, n. pag.)

The statement made by the NDP representative was met with loud "shames" from the Conservative stocks, indicating that the MP from Algoma had "gone too far" in comparing the policy of residential school to disinvestment in the Aboriginal Healing Foundation. But her statement addresses a larger problem with healthcare provision in Indigenous communities: that accessing "proper" healthcare for Indigenous peoples often requires travel or, as I have argued above, compliance the narrow parameters of the Health Canada programs.

The theme of compliance was central to the narratives of support for the Aboriginal Healing Foundation at the Emergency Debate. In 2009, the Aboriginal Healing Foundation was evaluated by two external bodies: the Institute on Governance, an Ottawa based non-governmental organization that specializes on evaluating governance, and the Department of Indian and Northern Affairs. A Legacy of Excellence: Best Practices Board Study: Aboriginal Healing Foundation (2009, 36-7) outlines the key indicators of success in their evaluation: the AHF Board mirrors the mission; the AHF Board guides a pan-Aboriginal organization that is very cohesive; the AHF Board has facilitated excellent relationship-building; The AHF Board has achieved admirable transparency and accountability; and the AHF Board has effectively managed a half billion dollars. 
Foundation: Final Report (2009), conducted by the department of Indian Affairs and Northern

Development, concluded:

Given the Settlement Agreement commitment by the GOC [Government of Canada], and keeping in mind the assessments of the number of survivors and intergenerationally impacted who are anticipated to need support; and the fact that Health Canada support programs are designed to provide specific services that are complementary but different to those of the AHF; and the reported numbers of survivors seeking help from AHF and Survivor Societies, the logical course of action for the future would seem to be continuation of support for the AHF, at least until the Settlement Agreement compensation processes and commemorative initiatives are completed. Expert key interviewees note that there is no equivalent alternative that could achieve the desired outcomes with the rate of success the AHF has achieved. (Graham and Mitchell 2009, 55)

This report was written and released in December of 2009, only four months before all funding was cancelled. This report noted that the Aboriginal Healing Foundation had complied with all criteria that had been outlined by the government. In fact, the AHF had exceeded expectations in levels of performance, transparency and accountability. Both evaluations gave glowing recommendations for the programs and recommended an extension of funding to fulfil the need for health supports for former residential school students and their families. In contrast, very little analysis of the Indian Residential School Resolution Health Support Program has been conducted, and in fact, as of yet no evaluations exist on the public record. ${ }^{102}$ In fact, very few details about the program are even publicly available. While the Health Canada website provides access to Compendiums, the information about the programs is very minimal.

\footnotetext{
102 In October 2012, I emailed Health Canada Media Enquiries to ask if an external audit or review had ever been conducted on the Indian Residential School Resolutions Health Support Program and, if so, was the review public? To this email, I received the following answer on November 2, 2012: "Recipients of Health Canada funding are bound by the terms and conditions of contribution agreements which require regular submissions of activity and financial reporting which ensures accountability for public funds." At the same time, there was no indication that service providers had ever been asked if the IRS RHSP program had helped them meet expectations and demands at the community level. Given that the program has been running for nearly 12 years, the level of reporting seems to benefit the state far more than the program personnel and "client" base. As contribution agreements are primarily focused on funding expectations and program outcomes, contribution agreements appear to be a limited "assessment" of the program's efficacy.
} 
In 2010, following the closure of the Aboriginal Healing Foundation, Health Canada officials made an announcement at the Assembly of First Nations Special Chiefs Assembly that a gap analysis report designed to document the loss of AHF programs would be conducted (Assembly of First Nations 2010 b, n. pag.). A gap analysis would evaluate the need for health support provision in Aboriginal Community, the loss of services that was engendered after the closure of the Aboriginal Healing Foundation, and offer strategies to ensure the needs were met despite the loss of AHF programming. Health Canada representatives relayed that this information would be shared publicly so as to demonstrate that healing support provision had not been disrupted despite the loss of AHF programming. After waiting for several months for its release, I began contacting Health Canada officials and was unable to get access to the report. Moreover, people seemed confused about what report I was talking about. Eventually, in 2011, I grew impatient and filed an Access to Information Request to obtain the report that I sought. After considerable back and forth with Health Canada Information officers, I soon realized that no report had in fact been written. In light of this information, I filed another Access to Information request that asked for any documentation or proof that any such analysis had taken place. I received 700 pages of information that included tables that recorded the number of practitioners in each region, as well as conversations between Health Canada employees, their regional counterparts and interactions with other ministerial departments, especially AANDC (or at the time of the gap analysis INAC). ${ }^{103}$ Finally, in the Fall of 2012, after a significant time lapse - almost a year from

\footnotetext{
${ }^{103} \mathrm{My}$ original request for information was denied, and a follow-up request was sent that narrowed my parameters significantly. This request came with the price tag of $\$ 1800.00$ and was likely to take an incredible amount of time. I was then contacted by the Information Officer by phone and asked if I wanted documentation from First Nations communities about their responses because, since this would require third-party permission, it would take longer and be more expensive. If I only wanted Health Canada's records, this information would be given to me for free. In hindsight, I wish that I had been more persistent and asked for a student discount, or applied for other funding to obtain this material.
} 
making my AI request-I contacted the Assembly of First Nations, who confirmed that a gap analysis report had still not be released and would never be released. Even if the announcement of the proposed gap analysis was premature, its necessity was vital. Therefore, what troubles me about this issue is not that a gap analysis report was announced and not released, but because a gap analysis was seemingly not conducted at all.

Despite blatant issues relating to Health Canada's lack of compliance in regards to accountability to former residential school students, the lack of a proper gap analysis report is problematic for the following reasons:

1) In the absence of a report, Health Canada did not inform the governing councils (Resolution Health Support Advisory Committee) to which the Indian Residential Schools Resolution Health Support program is beholden about the gaps in services. In conversation with two members of the RHSAC, I was informed that a copy of anything resembling a "gap analysis report" was not provided to supporting organizations and that any information collected by Health Canada about program shortages was simply incorporated within the department's yearly "work plan and strategies."

2) An assessment of the "gap" between health support programs can be read as methodologically unsound because the mere incorporation of findings into Health Canada "strategies" means a lack of reporting to communities from whom they extracted sensitive information.

3) If communities and Aboriginal organizations are under the impression that a gap analysis has been conducted then perhaps they would be dissuaded from conducting their own audits. ${ }^{104}$ Many governments and organizations have been funded through both programs and could offer important documentation and comparisons.

To adequately assess the gap in provision between the services provided during the Aboriginal Healing Foundation's tenure as well as the Indian Residential School Resolution Health Support Program, the number of healthcare professionals and monies spent must be assessed. In 2010, according to an Assembly of First Nations Resolution submitted by Indigenous communities, “only 134 Resolution Health Support Workers, 221 Cultural Support Workers, and 1,264 Service

\footnotetext{
${ }^{104}$ After I was unable to track down a gap analysis report conducted by Health Canada, I began contacting other organizations such as the National Metis Nation, the Chiefs of Ontario, the Nunatsiavut Government, Inuit Tarapiriit Kanatami, the National Association of Friendship Centres and the Assembly of Manitoba Chiefs (AMC). I received responses from all but the AMC, and none of the organizations had conducted a gap analysis report.
} 
Providers have been nationally provided by Health Canada. This level of resources is totally inadequate for former IRS students and families" (Assembly of First Nations 2010 a, 1). The total number of healthcare providers is 1,619 , which means that one healthcare provider is responsible for the healthcare of 49 survivors (if this number should include one family member per Survivor, also entitled to access these health supports, the ratio grows to 1:98). More optimistic numbers were provided by Health Canada in November of 2012 on the subject of health support provision. Numbers grew substantially to a total of 2,179 practitioners, with 286 Resolution Health Support Workers, 403 Cultural Support Workers and 1,487 Service Providers (email from Health Canada). ${ }^{105}$ The 2012 numbers are more promising in that the health provider/Survivor ratio registers at 1:36. ${ }^{106}$ An increase in health support workers from 2010 to 2012 was expected due to the creation of the Truth and Reconciliation Commission, which required health supports at all national and community events, and requested that additional health supports remain in communities following the closure of the events. The overall ratios that I have provided above are further complicated by several factors related to the narrow parameters and categories constructed the by Indian Residential School Settlement Agreement eligibility “class” (see Chapter Three). For instance, these numbers do not take into account the exclusion of certain survivors should their school not appear on the Official Schools List. ${ }^{107}$ Moreover, this number is further skewed by the

\footnotetext{
${ }^{105}$ The provision of these numbers came with certain stipulations. Firstly, that Cultural Support Workers were not employed on a full-time basis and that Service Providers are "registered Service Providers within Health Canada's Non-Insured Health Benefits (NIHB) Program, and are compensated on a fee-for-service basis."

${ }^{106}$ Upon closer look at service provision in the, the ratio for health support providers is $1: 44$. In the North there is a particular shortage of health providers, especially with the ending of residential school survivors. The Truth and Reconciliation Commission notes in their Interim Report (2012) that "In many cases, a single mental-health nurse in the North is expected to service a region that is the geographic size of an entire province. They do this without the benefit of road transportation or colleagues" $(2012,8)$.

107 Approximately 24,000 applications to CEP were rejected primarily because the school they attended did not appear on the Official Indian Residential School List (Aboriginal Affairs 2016). Also, many applicants were only granted compensation after applying for reconsideration or going through the appeal process, which are both timely processes. Therefore, claimants whose applications to CEP were delayed may have been unable to access mental health care through the Health Canada program.
} 
geographical inequity of service provision, which inevitably places remote communities, particularly those in the North, at further disadvantage since healthcare shortages in these communities already prevail.

One must keep in mind that the loss of the Aboriginal Healing Foundation did not only result in the loss of healing programs, but in the loss of employment for all those who worked in those programs. News sources covering the closure of the Aboriginal Healing Foundation cite the loss of 2/3 of all staff who worked at many of these funded programs. ${ }^{108}$ An email from Executive Director Mike DeGagne stated: "When we were told that our funding would not be renewed, we had to close 135 projects within a two month period. We estimated at that time that approximately 950 jobs would be eliminated. Normally we don't talk much about job loss. It is critically important but it also feeds our detractors agenda that suggests that the 'Aboriginal industry' is only concerned with jobs and not healing" (email correspondence, October 27, 2012). Dr. Degagne's assessment of the attitudinal biases related to AHF job loss is prevalent amongst Health Canada employees. In an email obtained from a Health Canada employee who was conducting a gap analysis report of Health Canada programming in the Manitoba region, the subject of job loss is broached. The Health Canada employee states:

Regardless of the amounts of money spent for services through the AHF, the effects are the same with regard to Survivors. To date we have only heard from a few individuals who are being affected by job loss from the closure of the AHF. It almost seems like the main concern is "jobs" lost and not the "services." (email obtained from ATIP May 17 2010)

\footnotetext{
108 In an article by Maya Roblin-Ghanie (2011, n. pag.) there is reference to job loss after the cuts to AHF funded programs. Citing the Native Women's Shelter in Montreal, she states “In response to the cuts, many staff at the Shelter have taken a pay cut, while at the same time taking on extra responsibilities. Two clinical supervisors are now sharing a salary, and the program coordinator has been laid off indefinitely. The Shelter is no longer able to pay elders to lead workshops, nor can it keep its art therapist". These job statistics are decidedly grim, but she goes on to write that "The Recovery and Wellness Centre in Gordon First Nation is facing similar cutbacks. At the end of March 2010, staff took a 50 per cent pay cut for the remaining three months of the Centre's operation" (RoblinGhanie no pagination).
} 
Given that this email was written on May 17, 2010, not even two months after the closure of programs, it is possible that many programs had not managed to contact Health Canada for funding support. Many programs were also granted a three month emergency grant by the AHF to wind down services in a realistic manner, and contact with Health Canada may not have yet been made. The loss of these jobs along with the closure seemingly flies in the face of the prevailing language of reconciliation used by the Harper Government: since discourses of reconciliation and healing are repeatedly conflated with participation in the wage economy and economic development, it is ironic that the closure of these programs actually contributed to economic loss. ${ }^{109}$

\section{Conclusion}

In this chapter, I have documented how terrain of health supports for Indigenous peoples in Canada has been defined through two dominant narratives: need and compliance (see also Spear 2014). Despite numerous reports demonstrating the need for Aboriginal Healing Foundation services and their exceptional record of compliance, the organization was subjected to disinvestment. Once AHF programs were de-funded, the only health support programs that remained were housed within Health Canada. These programs attempted to incorporate cultural safety mechanisms and Indigenous forms of health delivery, however, there was still an emphasis on psychotherapeutic approaches and contractual obligations to settler state. In this chapter, I address how Health Canada programs follow the same funding and policy strategies that have been

\footnotetext{
${ }^{109}$ Funding cuts in the health research and services would only deepen in the March 2012 budget, despite the Prime Minister's and Minister of Indian Affairs, John Duncan's, affirmation of commitments to the health and well-being of Indigenous peoples at the Crown-First Nation Gathering in January of that year. The release of the federal government's budget saw the extensive slashing of health budgets for Indigenous organizations. The Assembly of First Nations, Inuit Tapariit Kanatami, Native Women's Association, and Pauktuutit Women's Association saw their health budgets cut by $40 \%$. The Nation Aboriginal Health Organizations and the First Nations Statistical Research Unit were reduced to half their funding for the 2012-2013 year, and then these organizations were de-funded altogether the following budgetary year.
} 
critiqued by major health organizations over the past decade (Health Council of Canada 2011; Inuit Tapiriit Kanatami 2007; National Native Addictions Partnerships Foundation 2012). I also note that despite the excessive auditing of the Aboriginal Healing Foundation, the Indian Residential Schools Resolution Health Support Program has neither received an external evaluation nor did they conduct an official gap analysis report after the closure of the Aboriginal Healing Foundation. This leaves me to conclude that the well-documented shortage of health support programming and a lacking accountability to Indigenous communities in the delivery of health support services jeopardizes the settler state's commitment to reconciliation.

I also acknowledge that disinvestment in the Aboriginal Healing Foundation also seems to contradict the tenets of neoliberalism that insist on the creation of public-private partnerships, the downloading of services onto the voluntary sector and the reduction of government programs (see Tomiak 2011). While I believe that the neoliberal and colonial approaches to health support programming are entangled, a question for further exploration is how and why settler demands for control and Indigenous compliance are invoked even when they are more costly to the state. ${ }^{110}$ Does this imply a hierarchy of values embedded within the delivery of public sector programs in Indigenous communities? How have these values shifted over time under different government policy regimes?

In conclusion, I agree with scholars who outline the vulnerability of the Aboriginal Healing Foundation to neoliberal rationale, however, I think the organization introduced new and dynamic forms of governance and reporting that challenged government surveillance and enhanced the potential for community control over programming. While I agree with scholars who address the

\footnotetext{
110 Ghassen Hage (1998) has made a similar argument about refugees in Australia, where he suggests that xenophobic policy and the demand for separation is actually far more costly to the Australian government than a robust settlement policy.
} 
limitations of Aboriginal Healing Foundation programming imposed by neoliberal policy and rationale (see Million 2013; Molema 2011); the organization worked against the conflation of healing and economic development that was so prevalent in other compensatory mechanisms administered by the Indian Residential Schools Settlement Agreement. The importance of Indigenous jurisdiction and community autonomy was a central goal of the Aboriginal Healing Foundation and is more akin to decolonial politics. Where these scholarly critiques are fundamentally important to my analysis is how they identify discourses of trauma and healing as a means to appeal to settler interests (see Million 2013). Building on this critical point, the following chapter examines the pitfalls of requiring settler participation and partnership to facilitate reconciliation. 


\section{Chapter 6: "It's not like we are asking you to marry the government": The Politics of Partnership at the Truth and Reconciliation Commission of Canada}

Litigation creates adversaries, not partnerships. Litigation can be crippling because it forces us into positions we can defend rather than issues we can resolve (DIAND 2000, 6).

And when I hear about love today, because I've learned how to love myself, I'm so happy when I see my brothers and sisters and I meet them on the streets, it's like my heart...I can feel that love and I know we're not afraid to look at each other [Indigenous peoples] anymore (Joyce Labillis Atlantic TRC Event Transcripts 461).

During the Montreal Truth and Reconciliation National Event (April 2013), a Town Hall was held to elicit settler responses to the history of residential schooling. ${ }^{111}$ Describing the difficult task of creating a dialogue between the various IRSSA parties, TRC Commissioner Murray Sinclair jokingly remarked that while discussion was necessary and productive, the Commission was "not asking you [survivors] to marry the government" (personal transcript April 2013). While Commissioner Sinclair suggests that an intimate relationship is not required between Indigenous peoples and the Canadian state, he does insist that co-existence is necessary. Outlined in its mandate, one of the main principles of the Truth and Reconciliation Commission of Canada is to facilitate the "rebuilding and renewing of Aboriginal relationships and the relationship between Aboriginal and non-Aboriginal Canadians" (Indian Residential Schools Settlement Agreement 2005 a). This chapter asks: What role does the Truth and Reconciliation Commission of Canada play in facilitating and encouraging Indigenous-settler partnerships? Despite the tacit potential of Indigenous-settler partnerships, this chapter also asks: What do the politics of partnership obscure and what do the politics of partnership produce when performed in a neoliberal context?

There is little evidence to support the assumption that establishing partnerships with the settler state is a primary goal of Indigenous peoples during the reconciliation process. Many

\footnotetext{
111 According to the Montreal National Event's program, the It Matters to Me portion of the program is described as "Take part in a moderated dialogue about reconciliation and why it matters to each of us. Special guests will begin the discussion. After that, the microphone is open and you're invited to have your say" (TRC 2013, 31).
} 
Indigenous organizations have been averse to reproducing narratives of national public intimacy that are bolstered by the language of partnership. In fact, Indigenous organizations and grassroots leaders outside of the Truth and Reconciliation movement have demanded that decolonized relationships should be realized through the affirmation of Indigenous difference and the official acknowledgement of Indigenous peoples' jurisdiction. This chapter argues that the discourse of partnership functions as a therapeutic investment for the settler state and settler Canadians, and is used to situate economic success and national belonging as a vehicle for healing.

In this chapter I document how distinct meanings of partnership have been circulated to secure different outcomes for different actors in negotiating Indigenous-settler reconciliation. For instance, the Royal Commission on Aboriginal Peoples' Final Report (1996) envisioned partnership through the key principle of sharing, a concept that "calls for the giving and receiving of benefits in fair measure" (Nation to Nation 1996, n. pag.). However, discourses of partnership circulated by the Mulroney and Chretien governments were deeply influenced by an investment rationale that situated partnerships as a pathway to mutual economic benefits (see Chapter Two). As I discussed in chapter Four, the Harper Government conflated Indigenous-corporate and Indigenous-state partnerships with the act of reconciling. To counter the politics of partnership, Indigenous survivors and social movements have advocated for addressing relationships through strategic partnerships that seek to establish and strengthen intra-Indigenous relationships that can contribute to self-determination.

To examine the politics of partnership at Truth and Reconciliation National events, I examine a specific form of recurrent programming that requires the participation of former students and parties to the IRSSA, entitled Expressions of Reconciliation. As an actual (and virtual) attendee at Truth and Reconciliation National events, I was witness to the speeches and 
testimony where partnership was circulated as a primary discourse. While this chapter ultimately concludes that National Events help to perpetuate the belief that "rebuilding and renewing relationships" is synonymous with realizing a just Canada, I also point out the Commission's limitations in shaping a coherent or ideological public message concerning what it means to reconcile.

This chapter examines how discourses of partnership are used to mask the exploitative aspects of settler colonialism and neoliberalism through the truth telling process. Expressions of Reconciliation function as a therapeutic investment that can be inadvertently used to bolster settler and neoliberal projects through the deployment and celebration of partnership. The mechanisms that are used to publicly account for historical injustice are also used to reproduce the authority of the settler state and settler institutions. Firstly, I examine how relationship building and partnership is imagined as an important component of reconciliation for both settler and Indigenous institutions, albeit in very different ways. Secondly, I examine how these differing conceptualizations of partnership present challenges to settler participation in TRC programming. Lastly, I examine if and how discourses of partnership are deployed during "Expressions of Reconciliation" at Truth and Reconciliation National Events to bolster neoliberal projects that engender economic downloading.

\section{Settling Participation}

The Truth and Reconciliation Commission of Canada is the most well-known and wellresearched reparation strategy that has emanated from the Indian Residential Schools Settlement Agreement. Considered the most visible component of the IRSSA due to its participatory mandate, the TRC is meant to engage Indigenous and non-Indigenous peoples in a discussion about the legacy of residential schooling, and about the possible futures that can be imagined from 
reconciliatory goals. In the absence of retributive punishment for perpetrators, the Truth and Reconciliation Commission enacts a particular form of commemorative and testimonial justice. Therefore, the Truth and Reconciliation Commission of Canada should be understood as merely a means to decipher a pathway to justice, and should not be misconstrued as an end in itself. ${ }^{112}$

Truth and Reconciliation Commissions have been implemented all over the world as a means of dealing with the aftermath of state violence or warfare between actors. Commissions, like compensatory adjudication, are informal mechanisms of justice used to facilitate restorative and transitional models of justice. Originally constructed as a mechanism to advance liberal democracy after dictatorial rule, truth commissions "would, first, repair the psychic damage caused by repression and, second, prevent such repression from occurring in the future" (Grandin 2005, 47). Prior to the design and implementation of the South African Truth and Reconciliation Commission that took place in the 1990 s, public commissions that investigated the nature and extent of state violence often utilized punitive approaches to enacting justice. For instance, in Latin America, public inquiries were endowed with the authority to imprison or at least unseat dictatorial leaders, nonetheless, these decisions were predominantly made behind closed doors and outside the purview of a public who had been directly harmed and terrorized by state violence (see Grandin 2007). Of late, contemporary truth commissions are predominantly quasi-judicial and lack the power to incarcerate or punish offenders. They proffer a form of social accounting for wrongdoing by archiving documents and testimony and by initiating public dialogue between victims,

112 The Canadian Truth and Reconciliation was devised from a recommendation made by the Royal Commission of Aboriginal Peoples to hold a public inquiry into the history of the residential schools. Subsequently, both the Law Commission (2000) and the Assembly of First Nations (2004) insisted on restorative approach to redress and reparation. Through a series of roundtable discussions with First Nations and Inuit Survivors, TRC methodologies and programming were discussed and debated. While the feedback received from these consultative meetings was not always utilized, the Truth and Reconciliation Commission ensured ongoing Survivor input through the appointment of a Survivor Committee which was established from several representatives from every province (see Nagy 2014). 
perpetrators and bystanders of political violence (Ahmed 2005; Hamber 2009; Kennedy 2012; Mamdani 2005). The scholarly literature on truth commissions overwhelmingly focuses on acts of witnessing and testifying to political violence (Angel 2012; Hayner 2010; Moon 2008; Ross 2003). However, I assert that scholarly examinations of perpetrator participation are integral to analyzing the role of truth commissions for realizing justice, especially in the context of settler societies (see Ahmed 2005; Kennedy 2012).

The politics of partnership are of particular importance to the Truth and Reconciliation Commission of Canada since the voluntary participation of settler-Canadians is relied upon to complete its mandate. Kimberly Stanton (2010) foresaw potential problems in settler participation, in part because

the TRC will be faced with the need to prompt Canadians to invest in and take ownership of a process that they did not instigate. That is, the TRC was not created out of a groundswell of concern about IRS survivors by the public; rather it was agreed to by their government's legal advisers in order to settle costly litigation. Were it not for the enormous financial cost to the government of continuing to defend against the class actions, the TRC would not exist in Canada. (4)

Stanton outlines the lack of political will for settler-Canadians to reconcile with First Nations, Inuit and Métis survivors. According to her, the motivation to create a Truth and Reconciliation process is rooted in an unwillingness to pay a higher prices for reparations to former residential school students.

Settler participants may feel excluded from participating in the reconciliation process due to assumptions that the TRC is a therapeutic exercise, which should be dedicated to Indigenous peoples who can "talk" through past traumas and experiences. Nonetheless, the ability to "talk" openly and honestly about this history has been curtailed by the Canadian Truth and Reconciliation 
Commission itself because participants are told to refrain from naming abusers ${ }^{113}$ (generally former caretakers, but also former students) in their testimony, unless the person has been convicted in a court of law (see Niezen 2013; Regan 2010; Stanton 2010). ${ }^{114}$ Understandably, the decision to keep perpetrator testimony to a minimum may reduce public accusations of studenton-student abuse that could unsettle community healing and reconciliation (see Niezen 2013). Yet, as a result, perpetrator participation remains almost absent at national events, perhaps so as not to disrupt proceedings by making former students feel uncomfortable by the possibility of facing their aggressors.

The potential social and legal perils of perpetrator participation in the Truth and Reconciliation process are well-documented, but in the absence of perpetrator participation, it seems as though any insistence that former students should focus on reconciling with the state or settler society may be construed as irrelevant. Commissioner Murray Sinclair addressed this issue at Assembly of First Nations Annual General Meeting in July 2012:

When it comes to reconciliation...we need to think about the question of whether we should be addressing the healing of family first, before we go forward, before we can even begin to have a conversation about reconciliation with other members of society, before we can even begin to engage in acts of reconciliation with the government or with those who worked in the schools or those in other places in society. (Sinclair Assembly of First Nations Annual General Meeting August 2012, n. pag.)

The imposition of a mandate that privileges forgiving perpetration is construed as problematic by Sinclair because family and community rebuilding should take precedent over reconciling with the settler state. However, the lack of attention paid to the beneficiaries of colonialism could produce

\footnotetext{
113 The long wait in instituting the Truth and Reconciliation has also meant that many of the perpetrators have already passed away.

${ }^{114}$ The mechanisms to decide culpability were markedly criticized in certain reconciliation proceedings (i.e. in Chile and Argentina) because much of the testimony and document investigation was conducted behind closed doors and by unknown officials (see Grandin 2005). The South African Truth and Reconciliation Commission established a pronounced measure of transparency; however, the process was critiqued for offering amnesty to low-ranking officials who exacted violence in exchange for their public testimony (see Mamdani 2005).
} 
apathetic attitudes in settler-Canadians regarding the history of residential schools, reproducing myths of Indigenous privilege and increasing settler animosity. Taking this into account, the Truth and Reconciliation Commission needed to grapple with how to reduce settler apathy and settler animosity without sacrificing care for former students. In the sections that follow I suggest that creation and renewal of Indigenous-settler partnerships is how settler participation in instituted into TRC programming. These partnerships are either established tangibly through individuals or organizations, or are posited as an abstract objective of the process.

\section{Reconciliation Talk}

Scholars (Grandin 2005; Moon 2008; Nagy 2012) imagine Truth Commissions as a space where testimony is both given and received. As I note in the Introduction to this chapter, the National Events of Canada's Truth and Reconciliation Commission have been used as way to encourage discussion and debate surrounding the nature of reconciliation, its meanings and its outcomes. The opening of this space of conversation and debate is important, because despite the pervasive circulation of reconciliation, "[I]ndigenous peoples and central authorities make repeated references to reconciliation, but mean something different by it, with the result that they literally end up talking past each other" (Maaka and Fleras 2005, 289). In this chapter I focus particularly on the way that reconciliation is deployed by settler-Canadians, settler institutions and the settler state. Carole Blackburn (2007) examines how "reconciliation talk" is used by settler authorities to "emphasize modernist themes and modern temporality, involving the progressive movement away from the past into an improved future built on enlightenment values" (622). She suggests that "reconciliation talk links political legitimacy with the state's ability to recognize and overcome its colonial history, but leaves out the exclusionary tendency at the heart of modernity" (Blackburn 2007, 622). Blackburn's insistence that reconciliation may function as a way to obscure 
ongoing processes of exclusion and marginalization enacted through settlement calls into question the influence of restorative justice in providing reparations.

The implementation of a Truth and Reconciliation Commission was understood as a central restorative component of the Indian Residential School Settlement Agreement. Jennifer Llewellyn (2008) warns that restorative justice should not be viewed as a return or a restoration of past harmonious relationships, because the aim of this model "is to realize an ideal of human relationships" and is, therefore, occupied with "ensuring equality in social relationships, not intimate relationships, between individuals" (189, emphasis Llewellyn). Despite the potential for enhancing social relationships through restorative measures, Sara Ahmed (2005) cautions that "what is presumed in the literature on restorative justice is that injustice is caused by the failure of the social bond. The restoration of the social bond (the family, the community, the nation) is hence read as a sign of justice. Justice is also assumed to be about 'having' good relationships" (81). She goes on to note that what is sacrificed in the pursuit of relationship-building is the "right of others not to enter into relationships," and the search for justice requires parties to "feel good (about each other)" (Ahmed 2005, 81). In privileging the construction (or re-building) of social bonds, any desire for Indigenous peoples' autonomy or jurisdiction may be undermined or under-valued. When opposition to partnership is cited by Indigenous peoples, settler-Canadians may assume Indigenous peoples are clinging to past hurts when, in reality, many are demanding decolonized relationships.

While the Truth and Reconciliation process provides an opening for public discussion of what it means to reconcile for Indigenous peoples and for settlers, the Truth and Reconciliation Commission of Canada has also been understood by scholars as an exercise in "talk therapy." The assumption underlying talk therapy is that a person who has been harmed or injured psychically 
by a traumatic experience must undergo the therapeutic technique of "talking" through it. This comes from the Freudian method, called "the talking cure," which implies that a victim needs to remember and narrate their trauma in order to heal. "Talking" helps to bring painful experiences into the light and undermines the power of secrecy and internalized pain, thus minimizing suffering for the individual. Whether or not the person is conscious of the damaging effects of this experience, their access to memory is often compromised due to a disruption in the chronology of remembrance (see Caruth 1994; Leys 2000; Schwab 2006). Through the act of talking about traumatic events, the alignment of these events into a linear narrative helps to restore a sense of normalcy that has been disrupted through the experience of trauma. Instead, other scholars have identified how the Truth and Reconciliation Commission as a place of re-storying, as a forum to explore "counter-narratives of diplomacy, law, and peacemaking practices — as told by Indigenous peoples themselves" (quoted in Corntassel, Chaw-win-is, T'lakwadzi 2009, 138). This kind of restorying is necessary for decolonization processes, lest colonization "be the only story of Indigenous lives" (Corntassel et al. 2009, 139). Nonetheless, dominant discourses and values can be also be reproduced through testimonial exchange at these events (Corntassel et al. 2009). This chapter examines the role of truth commissions and settler testimony in reproducing these dominant ideas, while at the same time examining strategies that might help move beyond this framework.

\section{Indigenous-Settler Partnerships}

As I have argued throughout this dissertation, Indigenous-settler relationships have been fraught due to a history of colonial violence enacted primarily through residential school education, through the coercive domination of Indian Act (1876) governance and through the routine exploitation of Indigenous territory by state and corporate actors. Indigenous peoples' 
demands to relinquish or reform these relationships are primarily met with encouragement from the state to build self-sustaining communities, where partnerships govern the extension and receipt of funding and jurisdiction for social programming, infrastructure and economic development. Nonetheless, the politics of partnership are contested. Outside of the political sphere, some scholars have endorsed the establishment of partnership in Indigenous communities by "creating new models of self-determination through market partnerships designed to improve socioeconomic conditions" (Slowey 2008, xviii). In response to the optimistic embrace of partnership that may yield some positive results for Indigenous peoples, Julie Tomiak (2011) reminds us that "the reality is that the nature of partnerships continues to be unilaterally determined by the federal government. Given the profound unwillingness of the state to relinquish jurisdiction, neoliberalization hardly constituted a reversal of the colonial logic of settler state intervention" (53-54). For this reason, Tomiak cautions that the concept of partnership within Indigenous-settler relationships is defined by inequity and restrictive parameters that are imposed on First Nations communities. Concepts of partnership are also primarily deployed as mechanisms to curb government spending and attract corporate investment.

Indigenous scholars have expressed concern that settler-Canadians regard reconciliation as a re-establishment of historical relationships that have been disrupted by residential schooling, as an exercise in misplaced benevolence. Chrisjohn and Wasacase (2009) note a profound misunderstanding of the history of Indigenous-settler relationships, as well as the process of reconciliation. They critique the marriage metaphor, often used to describe conflict resolution, for likening Indigenous-settler relations to a strained but meaningful relationship such as a marriage, where "the path of true love rarely runs smoothly, and the union may be dissolved for one reason or another. There is and has been for centuries any number of interventions (....) aimed at healing 
the rift, whatever its basis. Reconciliation, then, is the success of these enterprises, a restoration to the earlier condition of a single, shared and combined effort" (Chrisjohn and Wasacase 2009, 221 author emphasis). John Amagoalik (2012) dismisses assumptions that relations between Indigenous peoples and settler Canadians were at one time harmonious. Instead, he states that the "[t]he history of this relationship is marked by crushing colonialism, attempted genocide, wars, massacres, theft of land and resources, broken treaties, broken promises, abuse of human rights, relocations, residential schools and so on" (35). Narratives of partnership and accord can be used to minimize the history of violence enacted against Indigenous peoples by the settler state, and thereby serve as an impediment to achieving justice for those upon whom this violence is inflicted.

The Royal Commission on Aboriginal Peoples imagines Indigenous-settler state relationships through a model of sharing. This principle is described as

the basis on which Canada was founded, for if Aboriginal peoples had been unwilling to share what they had and what they knew about the land, many of the newcomers would not have lived to prosper. The principle of sharing is central to the treaties and central to the possibility of real equality among the peoples of Canada in the future. (People to People 1996, n. pag.)

The concept of sharing, as it is deployed here, functions as a reminder of the role that Indigenous peoples have played in the survival and enrichment of their settler-Canadian counterparts. The fact that this survival and enrichment came at the expense of Indigenous peoples' prosperity is not inconsequential. Sharing in this context carries with it a desire for social justice and redistribution of resources and power, which requires the recognition of jurisdiction (implemented through treaty sovereignty) to instigate and support economic equality for, and decision-making capacity to, Indigenous peoples. With the release of Gathering Strength: Canada's Aboriginal Action Plan (1998), Indigenous-settler relationships were conceived of through the idea of partnership, which required 
celebrating our [Canada's] diversity while sharing common goals. It means developing effective working relationships with Aboriginal organizations and communities. Above all, it means all levels of government, the private sector, and the individuals working together with Aboriginal people on practical solutions to address their needs. Our common aim should be to strengthen Aboriginal communities and economies and overcome the obstacles that have slowed progress in the past. (n. pag.)

This description of Indigenous-settler relationships noticeably undermines the decolonial goal of extended jurisdiction and the possibility for redistribution. By conceptualizing Indigenous-settler relations in such a way, Indigenous peoples are placed in a position where the help of the settler state is needed. There is a difference between assuming that the disruption of these relationships has resulted in Indigenous dysfunction and viewing Indigenous dysfunction as the result of these relationships. Moreover, these relationships were fraught long before the establishment of the residential school system.

The prospect of "renewing the partnership" was initiated to help establish "the preservation and promotion of Aboriginal languages; increased public understanding of Aboriginal traditions and issues; inclusion of Aboriginal partners in program design, development and delivery; government willingness to explore how existing systems might be improved; and addressing the needs of urban Aboriginal people more effectively" (Hurley and Wherrett 2000, n. pag.). Nonetheless, the prospect of modern "partnership" requires problematization since this term has also been a mainstay of neoliberal economic policy. Partnership under these conditions is premised on the possibility of generating prosperity for the nation-state, and Indigenous peoples are only entitled to become a mutual beneficiaries. The discursive politics of partnership becomes relevant to the official reconciliation process when, as Jane Stewart notes in her 1998 Statement of Reconciliation,

[i]n renewing our partnership, we must ensure that the mistakes which marked our past relationship are not repeated. The Government of Canada recognizes that policies that sought to assimilate Aboriginal people, women and men, were not the way to build a strong 
country. We must instead continue to find ways in which Aboriginal people can participate fully in the economic, political, cultural and social life of Canada in a manner which preserves and enhances the collective identities of Aboriginal communities, and allows them to evolve and flourish in the future. Working together to achieve our shared goals will benefit all Canadians, Aboriginal and non-Aboriginal alike. (n. pag.)

The need for Indigenous and non-Indigenous peoples to work in some aspects is not absent from demands for jurisdiction and self-determination (see Maaka and Fleras 2005). However, partnership can easily slip into a quest for mutual beneficiaries and a means to instigate economic development. For example, Charles Coffey of the Royal Bank of Canada refers to the importance of establishing partnerships with relation to the Royal Commission's theme of "the cost of doing nothing" by stating: "These costs are significant and serious. They concern us deeply-as individual citizens who care about the society we live in and as corporate citizens concerned with broad and sound public policy. But, our interest in and advocacy about relationships between Aboriginal peoples and Corporate Canada go beyond corporate citizenship and public policy. Good relationships are also smart business" (Coffey 1998, n. pag.). This quote reinforces the need for Indigenous peoples to participate in the wage economy and contribute to Canadian society, revealing the underlying logic of the convergence of partnership and reconciliation. What remains unsaid in the quotes above is perhaps the biggest obstacle to establishing appropriate partnerships: that is, the incommensurability of Indigenous peoples' and settler goals. For instance, the expressed desire to construct a framework for self-determining communities may in fact be antithetical to the realization of settler goals.

In an official statement, read by Commissioner Sinclair in September $2010,{ }^{115}$ he noted that the "Truth and Reconciliation Commission is a cornerstone of the Indian Residential School

\footnotetext{
115 On September 28, 2010, the Truth and Reconciliation Commission of Canada attended the Standing Senate Committee on Aboriginal Peoples, in order to give testimony detailing any progress made since Stephen Harper's 2008 apology to residential School Survivors.
} 
Agreement" and that "[t]his agreement [IRSSA] gave Canadians a new beginning and an opportunity for Aboriginal and non-Aboriginal people to move forward, together, in partnership" (Standing Senate Proceedings 2010, 2 emphasis mine). While he did not elaborate further on the parameters of Indigenous-settler partnership, he maintained that the Commission is "charged with capturing and preserving more than a century of Canadian history, and bringing about healing through education and reconciliation" (Standing Senate Proceedings 2010, 2). In this context, partnership is more akin to a shared accountability, where settler-Canadians and Indigenous peoples work together to ensure that historical injustice is acknowledged.

During Truth and Reconciliation events, the discourse of partnership is generally maintained through the construction of formal and informal practices of "sharing," pedagogy, and truth-telling that are operationalized through individual testimony and witnessing. Yet, at the Opening Ceremonies of the Winnipeg National Event of the Truth and Reconciliation Commission, then Minister of INAC, Chuck Strahl, stated:

We're here today at the first of seven national TRC events, which are geared to working toward new partnerships and a stronger, respectful relationship amongst all people. These are important gatherings; they're bringing people together in a spirit of reconciliation and engagement. It starts today and continues on for the next several years. Events such as this one - public ones, private meetings - all of them are important in this ongoing journey toward healing and reconciliation and they're all steps that will help us to open a new era founded on renewed hope, faith, mutual respect and trust. (Office of the Minister of Indian Affairs 2010, n. pag.)

While facilitating dialogue and relationship-building are explicit goals outlined in the mandate of the TRC, these objectives cannot be separated from political and economic partnerships central to the policy apparatus maintained by the settler society.

In this section I have identified the different conceptualization of partnerships that have been deployed by Indigenous peoples and by settler-Canadians. The fundamental difference is that one notion of partnership was already extended to settler-Canadians at the moment of contact, at 
which point it was exploited to ensure material gain for one group, and oppression for others. The trivial deployment of partnership after such historical violence compromises the spirit of reconciliation, justice and decolonization.

\section{Expressing Reconciliation}

The archive that I examine in this section of the chapter consists of what are generally referred to as "gestures of reconciliation," offered to former students or the Truth and Reconciliation Commission during special sessions known as Expressions of Reconciliation. These sessions are described as an opportunity for "individual organizations and representatives of the parties to the Residential Schools Settlement Agreement" to approach the Commission and "make statements, presentations, or apologies directly to Survivors" (Truth and Reconciliation Commission of Canada "Expressions", n. pag.). These sessions generally include visitations from dignitaries and officials who have asked to make a gesture prior to the event's commencement. I only note this because, unlike most events, the Expressions of Reconciliation are planned, and therefore, the statements provided are generally scripted for this portion of the TRC's programming. ${ }^{116}$ At these sessions, the media is visibly present and all three Commissioners are in attendance. ${ }^{117}$ Indigenous and non-Indigenous peoples are invited to offer gestures during these sessions, but settler participation is generally more visible in these sessions than in any other event

\footnotetext{
${ }^{116}$ The provision of testimony, for example, is only decided the day of (or the day before) its witnessing. While some of the testimony is written out ahead of time, much of the testimonies are told as narratives that are articulated on the spot.

${ }^{117}$ I mention this because the larger the events grow, the fewer the occasion when the Commissioners appear together. This is primarily because of the number of participants who wish to share their stories. I know at the Saskatoon event, there were four simultaneous sharing circles which were led by the Commissioners and two lead by the Survivor Committee. This is fundamentally different than the first National event which was held in Winnipeg in June 2010, where all three Commissioners participated in sharing circles (except in gender specific circles). This event engendered an enormous amount of anxiety about people having the chance to speak or people being cut off. In Winnipeg, people were allowed to speak for approximately 5-7 minutes, in Saskatoon everyone was given 15 minutes.
} 
(even more so that in the Town Hall Forums or Circles of Reconciliation). ${ }^{118}$ The time slots earmarked for these sessions highlight the importance of this formal programming, as they were generally scheduled for times when a larger audience would be present. They rarely took place when concurrent sessions were planned.

Expressions of Reconciliation generally occur once daily at the national events and are guided by a specific ceremonial protocol. Each gesture or expression of reconciliation is associated with a tangible object which is placed into the Bentwood Box-a carved wooden box that travels with the TRC to all national events ${ }^{119}$ - by the TRC Commissioners. All objects are then placed in the Bentwood box with all giving and receiving parties touching the object, including the three Commissioners. As outlined at the Northern National Event, the Expressions of Reconciliation are conducted "in the presence of witnesses and the Survivor Committee" (Truth and Reconciliation Commission of Canada "Bentwood Box", n.pag. ). ${ }^{120}$ The contents of the box will become a part of the Truth and Reconciliation Commission's archives, which is to be housed at the University of Manitoba. The Expressions of Reconciliation portion of the programming is generally hosted by the Truth and Reconciliation Commission's Survivor Committee, ${ }^{121}$ since expressions are almost always presented to TRC Commissioners.

\footnotetext{
${ }^{118}$ While "expressions" or "gestures" of reconciliation may have been offered at the Winnipeg event, they were not officially named as this portion of programming did not exist. However, I will reference one "gesture" in particular, initiated by then Minister the Hon. Chuck Strahl, who was consequently later made an Honourary witness at the Vancouver National Event. The Expressions of Reconciliation portion of the Inuvik event were held each day after the opening ceremonies in Sir Alexander Mackenzie School which was the main site of public testimony at the multibuilding event. At the Atlantic event in Halifax, the Expressions of Reconciliation generally took place at the evening ceremonies at the end of the day and on a large stage situated in the Conference Centre. In Montreal, Expressions of Reconciliation were generally offered first thing in the morning.

${ }^{119}$ At the Northern National Event, the history of the Bentwood Box was provided. It arrived at the Ottawa Office on April 27, 2009 from Vancouver Island, British Columbia. It was steamed and bent from one piece of red cedar by Coast Salish artist, Luke Marsden. The carvings represent the artist's grandmother's experiences at the Cooper Island residential school (see Truth and Reconciliation Commission of Canada "Bentwood Box", n. pag.).

${ }^{120}$ I have outlined the role of Honourary Witnesses and the TRC Survivor Committee in Chapter Two.

${ }^{121}$ The Truth and Reconciliation Commission's Survivor Committee is a ten person advisory committee (made up of five women and five men) with members chosen to represent the major regions of Canada where Survivors currently
} 


\section{Investing in Affective Partnerships}

This section analyzes a few Expressions of Reconciliation that were narrated at Truth and Reconciliation National events. I characterize these expressions in a way that is similar to settler expressions of regret in the Sorry Book campaign in Australia (see Kennedy 2011; Ahmed 2005). What I observe in these settler expressions is the deployment of reparation displacement, which Matt James' (2009) suggests "works subtly, redirecting understandings of responsibility" and "occurs when questions of cause, blame, and obligation are shunned away, more or less systematically, from a community that ought properly to be asked them" (364). Therefore, unlike the medicalization of compensation, the politics of partnership is noteworthy for what it obscures rather than what it produces. While compensation produces discourses of emancipatory capitalism, the politics of partnership obscures the history of capital in suppressing Indigenous peoples.

On October 29, 2011, University of Manitoba President, David Bernard, made an official apology for the university's role in the Indian Residential School System at the Atlantic National event of Canada's Truth and Reconciliation Commission. In a statement conveyed as an "Expression of Reconciliation" on behalf of the university, Bernard stated that "the University of Manitoba wishes to take a leadership role in helping expose the national shame of the Indian Residential School system, and the consequences of such a system." The public statement was delivered to a sizable audience at the opening of the second day of TRC programming. Dr. Bernard stated:

Our institution failed to recognize or challenge the forced assimilation of Aboriginal peoples and the subsequent loss of their language, culture and traditions. That was a grave mistake. It is our responsibility. We are sorry. The university has a responsibility to acknowledge the harm inflicted on First Nations, Métis and Inuit survivors, their families and their communities. (Atlantic Event Transcripts 2011, 177)

reside. They attend all National events, as the Committee is often responsible for maintaining Sharing Panels so that the Commissioner's Circle does not become overwhelmed. They are also front and center at many formal events, both at National Gatherings and at other ceremonial or conference-oriented events. 
His apology represents a complex issue regarding not only the history of residential schooling but also to Canada's role as colonizing power, where these logics may be reflected in all public institutions. As a university administrator, he acknowledged an institutional failure that led to the education and training of staff who taught and administered the IRS system. Moreover, since federal-Indigenous relations dominate reconciliation processes in Canada, this gesture introduced a wider perspective of culpability that speaks to issues of settler apathy in regards to residential schooling. More importantly, the apology remains unique as it acknowledges a wider institutional culpability in perpetuating assimilationist policies. Since the state or church entities are routinely placed in positions of blame and responsibility, widening the purview of those who actively participated in maintaining colonial logic is required for reconciliation and decolonization to occur.

In taking the transformative pedagogy of the Truth and Reconciliation Commission of Canada as its central goal, Dr. Barnard noted that this practice would be extended at the University of Manitoba:

At the University of Manitoba, we have a positive story to share about Indigenous achievement. The University of Manitoba believes that education has a transformative power for students, their families and communities. We will work to ensure the values of First Nations, Métis and Inuit cultures and communities are included in scholarship and research across the university. In order to take the next step in advancing Indigenous scholarship and the success of Indigenous people, collectively as well as individually, we must acknowledge our mistakes, learn from them, apologize and move forward in the spirit of reconciliation. (Atlantic Event Transcripts 2011, 181)

In the same speech, the shame of the institution's past is then morphed into the positive contribution the institution is now making in the lives of its Indigenous students. In this sense, the "politics of bad feeling" that Ahmed (2005) suggests blend seamlessly into the politics of love in 
this speech, since pride in the institution must be re-instated. ${ }^{122}$ In his speech, Dr. Barnard notes the intergenerational "transformative" power of education for Indigenous peoples. The importance of the educational component of the compensation process was an opportunity for social "betterment" and increased contribution for Indigenous peoples in Canadian society. The TRC functions as the predominant pedagogical institution that preserves the history of residential schooling; moreover its key representatives and Commissioners have gone to great lengths to ensure curricular change in the elementary and secondary school systems ${ }^{123}$ as well as establishing a National Research Centre (NRC). Yet, anti-colonial scholars have critiqued the limitations of pedagogy and have advocated for a need to move beyond the "decolonizing one's mind and the rest will follow" approach (Tuck and Yang 2012, 20). ${ }^{124}$ I challenge conceptualizations of reconciliation that suggest that simply "knowing" about historical injustice is tantamount to structural change or decolonization. While "knowing" about historical injustice is central to linking these occurrences to contemporary conflict and social injustice, it does not ensure a critique of racism or capitalism that holds these structures in check.

Since voicing this apology, the University of Manitoba has been asked to house the Truth and Reconciliation Commission's National Research Centre, which is viewed as a central component of the TRC's mandate. The Mandate for the Truth and Reconciliation Commission "Schedule N" suggests that one of the TRC's responsibilities is to "establish a research center and

\footnotetext{
122 The University of Manitoba provided their apology on Oct 29, 2011, however, there was some skepticism since this event followed so closely behind their dismal ranking in the MacLean's University Rankings, which was released on Oct. 26, 2011 (see Blaze Carlson n. pag.).

${ }^{123}$ It is important to note that the Northwest Territories was the first provincial or territorial government to construct and implement curriculum that documents the history of residential schooling. This was announced at a March 2011 conference in British Columbia that was hosted by the Truth and Reconciliation Commission of Canada.

${ }^{124}$ For this reason, I also reject (alongside Andrea Smith) reductive pedagogical approaches that imply "if people simply understood Native peoples better, Natives would then become fully human" (Smith 2010, 42).
} 
ensure the preservation of its archives" (Indian Residential Schools Settlement Agreement $2006 \mathrm{c}$,

4). The research center is described as follows:

A research center shall be established, in a manner and to the extent that the Commission's budget makes possible. It shall be accessible to former students, their families and communities, the general public, researchers and educators who wish to include this historic material in curricula. For the duration of the term of its mandate, the Commission shall ensure that all materials created or received pursuant to this mandate shall be preserved and archived with a purpose and tradition in keeping with the objectives and spirit of the Commission's work. The Commission shall use such methods and engage in such partnerships with experts, such as Library and Archives Canada, as are necessary to preserve and maintain the materials and documents. To the extent feasible and taking into account the relevant law and any recommendations by the Commission concerning the continued confidentiality of records, all materials collected through this process should be accessible to the public. (TRC 2012, 10)

The National Research Center has been a cornerstone of the TRC's mandate primarily because it is representative of the Commission's main legacy. Moreover, it constitutes a continuing archive that is defined by expert personnel and existing spatial integrity.

A Signing Ceremony was held on June 21, 2013 where Commissioner Sinclair stated: "It began with the President's apology in October 2011, an academic institution taking responsibility for their part in the education [and assimilation process]," which Sinclair suggests "was a factor that showed us that there was a very strong commitment here to truth and reconciliation, and the proposal by the $\mathrm{U}$ of $\mathrm{M}$ stood head and shoulders above the other proposals because it was also national in its scope" (Centre for Human Rights Research, n. pag.). Therefore, the apology or "expression of reconciliation" led to a political partnership that was constructed to share the responsibility of commemorating or archiving testimonial materials to ensure that knowledge of the IRS histories are open to the public. In a presentation by University of Manitoba, Dr. Bernard presented a commitment to fund three positions (Director, Head of Research, and Archivist) for 10 years, as well as administrative and IT support, with a promise to create and renovate space for the Centre to exist (Centre for Human Rights Research, n. pag.). The University of Manitoba also 
outlined that a Governing Circle would be established, made up of seven people (three of whom must be a Survivor or a descendant of a Survivor). Moreover, several partners were named, such as University of British Columbia, Lakehead University, University of Winnipeg, University College of the North, University de Saint-Boniface, Red River College, and the Legacy of Hope Foundation. Typical of most public institutions, the University of Manitoba used this opportunity to brand itself as an institution that housed ground-breaking programs, particularly in the field of Indigenous Studies. This is a familiar narrative, a practice of innovative entrepreneurship that is so prevalent in neoliberal times.

What these celebratory partnerships disguise is the de-funding of both the university sector and the national library system, as well as the general dismantling of research prospects, by the Harper government. Paulette Regan (2010) notes that the History Wars in both Australia and Canada represent a struggle over the meaning of history in a settler society (73-4). Contestations over the erasure of Indigenous histories and the sanitization of settler histories were central for 'warring' historians, archivists and librarian struggling to construct multicultural and inclusive histories that enabled and advanced the cause of reconciliation. In a 2013 blog post on ActiveHistory.ca, Sean Kheraj states that, unlike Australia, the meaning of history is not the source of the history wars in Canada, but it is "battles over public financing of historical research and historical preservation" (n. pag.). The dearth of public monies dedicated to archive (and research in general under the Harper government) impacts of historical preservation highly undermines the state's commitment to reconciliation and expanding historical consciousness. It also undermines the rhetoric of partnership that is repeatedly deployed by the government in relation to reconciling with Indigenous peoples. A specific case study where the concept of partnership and historical preservation has been mired in conflict and mismanagement is the government's relationship with 
The Truth and Reconciliation Commission. Understood as a predominant pedagogical institution, the TRC has gone to great lengths to ensure curricular change and also to establish a National Research Centre. The challenges in creating this Center mirror the larger policy implications of public archives and research. The government's commitment to commemorating residential schooling was called into question in terms of its inability to provide appropriate documentation to the Truth and Reconciliation Commission of Canada so they could conduct proper research.

The government's commitment to archiving and commemorating residential schooling was called into question in terms of its inability to provide appropriate documentation to the Truth and Reconciliation Commission of Canada so employees could conduct proper research. In 2012, a lawsuit was filed against the Government of Canada that stipulated that required documents were not provided to the Truth and Reconciliation Commission. The Truth and Reconciliation Commission's Interim Report (2012) cited two main problems with document retrieval, lack of cooperation and cost-related issues, both of which

have placed the Commission's ability to fulfill its mandate in jeopardy. They also threaten to undermine the National Research Center that the parties have called on the Commission to establish. Having tried unsuccessfully to informally resolve these issues, the Commission has determined that it must seek judicial guidance. The Commission will be referring these matters to the supervising court for advice and guidance on how best to ensure timely compliance by all parties with their document production obligations. (17)

In Chapter 6 "Creating a Historical Record of the Indian Residential Schools" of the 2013 Auditor General Report, the Government of Canada was accused of neglecting their duty to provide appropriate documents for researcher purposes (1-27). Whereas the TRC was censured for not establishing further clarity on what constituted a "necessary" document from the Library and Archives Collections (Auditor General 2013, 1-27). The Auditor General's report highlights frayed institutional communication as an obstacle to the realization of the TRC's mandate in a timely manner. The Report's interpretation of the lack of partnership between the Government of Canada 
and the Truth and Reconciliation Commission is particularly salient given the TRC mandate which highlights sharing and exchange. The settler state's denial of responsibility to provide documents to the TRC calls into question the commitment to historical and financial accountability to the TRC proves contradictory to the demands for partnerships routinely noted in Indigenous-settler relations. The lack of "partnership" that has been described here is of particular importance not only for the Truth and Reconciliation Commission's mandate, but for the reconciliation process writ large.

Next to the settler state, the primary beneficiary of partnership in the settler society is the corporate sector. Corporate actors did not readily participate in Expressions of Reconciliation, but they were not absent from the Truth and Reconciliation Commission National Events. They were primarily silent partners who "sponsored" events, in which promotional videos were often shown. At the Saskatoon event on June 22, 2012, former National Chief Phil Fontaine gave an Expression of Reconciliation as a representative of the Royal Bank of Canada:

It's critical that we continue along this journey educating Canada about the history of Residential Schools and the impacts it has had on Aboriginal children and their families. Through the telling of their stories and experiences, truth will be known, healing will begin, and sincere reconciliation made possible. As Special Advisor for the Royal Bank of Canada, I provide advice and counsel to RBC's Canadian businesses to help the company deepen its relationships with Aboriginal governments, communities, and businesses in Canada. We, together as fully engaged partners, work closely with Aboriginal communities to move along a path of learning and understanding with the shared goal of making a positive difference. (Saskatoon Transcripts 203-4)

He then pledged $\$ 100,000$ for the next two years in support of the Truth and Reconciliation Commission of Canada. That same month, the Royal Bank of Canada released the Aboriginal Partnerships Report, which is released annually, detailing the extensive programs that the bank has undertaken with Indigenous peoples. The former National Chief had an entire page dedicated to him in the 24-page brochure, accompanied by the following text: 
As a young boy growing up on-reserve in Manitoba, Phil Fontaine had a tough life. His experience, unfortunately, was far from unique due to the same extreme poverty plaguing many other First Nations. Later in life, breaking the cycle of First Nations poverty and creating opportunities for the next generation became a mission for Fontaine, especially during his former public role as National Chief of the Assembly of First Nations (AFN). As he moved into the private sector, he concluded one of the best ways he could continue to help eradicate First Nations poverty was through RBC. RBC was one of the first companies, and the only bank, to join the AFN's Corporate Challenge by signing a Memorandum of Understanding agreeing to establish, enhance and increase their activities with First Nations governments and businesses. (Royal Bank of Canada 2013, 7)

Phil Fontaine's life relays a bittersweet entrepreneurial story where poverty is transformed into corporate success. The commitment to partnership is primarily validated through the acknowledgement of Indigenous peoples' vulnerability. As an architect of the Indian Residential School Settlement Agreement, Phil Fontaine's endorsement of RBC partnerships is pertinent to the influence of economic development rationale and policies that are applied in Indigenous communities.

By using one of the main proponents of the Indian Residential Schools Settlement Agreement to deploy the narrative of bootstrap capitalism, the Royal Bank is easily able to assert their influence over economic development projects. This is consistent with what Ruth Wilson Gilmore (2009) has identified as an "“infrastructure of feeling' otherwise known as the way that feeling is manipulated and substituted to create investments in different political projects"(n.pag.). This infrastructure of feeling is primarily built on sentimentality, which Lauren Berlant describes as

the means by which subaltern pain is advanced in the dominant public sphere, as the true core of national collectivity. It operates when the pain of intimate others turns into the consciousness of classically privileged national subject, in such a fashion that they feel the pain of flawed or denied citizenship. (qted in Kennedy 2012, 257)

Yet, the inability of the Royal Bank to recognize their role in the operationalization of coloniality, even if their participation in the residential schools was "minimal," the narration of Fontaine's 
biography can be understood as an example of "cold intimacy" (Illouz 2007) where highly emotive narratives are bolstered by the supposition of commercial and entrepreneurial benevolence. The Partnerships report (2013) also suggests that

[a]t RBC, we recognize and respect the desires of Aboriginal peoples in Canada for selfdetermination and self-sufficiency. We take pride in our support for programs that enhance the economic, social and physical well-being of Aboriginal communities and individuals. In this regard, our priorities include youth education and literacy, cultural expression and clean drinking water. (5)

Investment in the publication of glossy magazines to celebrate the promise of healing and wellbeing through economic development is not uncommon.

In fact the TRC itself has been sponsored by corporations directly responsible for the destruction of Indigenous peoples territory such as Syncrude, BC Hydro, CIBC, and Enbridge. As a result of these political partnerships, the TRC has been subject to some controversy. For example, an event in Vancouver in the Fall of 2013 fell under some scrutiny because it was being funded by Kinder Morgan. More than just another example of neoliberal co-optation of reconciliation processes, it also reveals the deeply structural, economic and continuing nature of settler exploitation. Intercontinental Cry Blogger Khelsiem Rivers wrote "The Residential School system had sought (among many things) to displace Indigenous peoples from our homelands; yet again, these companies are seeking to displace our peoples from our homelands to reap the benefit at our expense" (Rivers 2013, n. pag.). Appealing to settler elites who are enacting oppression and dispossession in real time warrants a significant degree of reflection. The question of who should be invited to the table to discuss and enact reconciliation remains an important one.

Another illustrative example of the concealment of histories of violence through the notion of partnership is the expression of reconciliation provided by the Royal Canadian Mounted Police. At the Atlantic National Event, Deputy Commissioner Steve Graham from the Royal Canadian 
Mounted Police delivered a presentation of the summary of a research project that "documented" the institution's involvement in the residential school system:

Although the research found that the RCMP was not an active participant in the school system, it did conclude that the RCMP assumed a responsible law enforcement role within the system. Our role included transporting children to the schools at the request of the school administrators and Indian Agents, assisting and looking for and returning runaway children to the schools, locating parents who refused to send their children to school and informing them of their obligations under the Indian Act. (Atlantic National Event Transcript 2011,575)

Many participants claim that their first memory of residential schooling is the arrival of the police in their community to escort the children to school. This non-apology (James 2008) can be read as way of absolving the RCMP of its responsibility, firstly for enacting the violence of removal against children and their families, and then for their negligible response to reports of abuse.

The 463-page report ${ }^{125}$ stated that the RCMP were heavily involved in the removal of children from their homes and the delivery of students to the schools, yet the RCMP concludes that they had no involvement with the administration of the schools and could not have known about the crimes because the "Indian Residential Schools were essentially a closed system. As a result, the problems within the schools didn't attract police attention or police intervention because they were dealt with, for the most part, internally" (Atlantic National Event Transcript 2011, 576). What is particularly interesting about the Executive Summary of this report is the use of affect to absolve the RCMP's lack of intervention in the residential school system. The Summary states:

Many interviewees said they learned to fear and not trust the RCMP over the years. The police were not perceived as a source of help but rather as an authority figure who take members of the community away from the reserve or makes arrests for wrong-doing. As a result, many students did not even try to contact the police. Fear, feelings of guilt and shame and perceptions that they would not be believed played a strong part in not revealing their experiences. A minority of students did, however, indicate they talked among themselves

\footnotetext{
125 The Report was conducted through an internal audit by employees of the Royal Canadian Mounted Police. Moreover, while an executive summary of the document is found online, the full document is not and one must contact the RCMP to get access to the document. Although some were made available at the Atlantic National event, I did not see them made available at the following even that I attended.
} 
looking for support and relief. (RCMP Report 2011, n. pag.)

Here the presumed guilt and shame of "vulnerable" survivors who have suffered "abuse" is used to explain the RCMP's lack of intervention in the schools. Moreover, the coloniality of power was well-maintained on reserves by the presence of the RCMP, whereas the threat they posed to Indigenous people historically are positioned as "perceived" threats. As new information about policy brutality, ${ }^{126}$ police complacency, ${ }^{127}$ and the history of standoffs in Indigenous communities becomes documented, the act of reducing Indigenous "fears" to a matter of perception can hardly be considered a reconciliatory commitment.

Upon closer inspection of their website, the Royal Canadian Mounted Police dedicate one of their five strategic priorities to policing in Indigenous communities. It reads as follows:

Our shared and unique history with Canada's Aboriginal peoples provides an environment in which we can work collaboratively to improve community health and wellness. We are committed to continue building upon these relationships as we encourage, sustain and foster honest and open dialogue among our Aboriginal partners. As we work together, the RCMP is in a position to assist and advocate for Aboriginal communities at a local and national level. (RCMP Strategic Priority n. pag.)

Contrast the partnership outlined in this "priority" to the experiences of members of the Mik'maq Nation at Elsipotog in the Fall of 2013. Less than two years after their "expression of reconciliation", on the very same territory where the RCMP Report was provided, a standoff occurred where anti-corporate protesters experienced not only aggressive attacks from RCMP forces, but Indigenous treaty rights were questioned and derided outright by RCMP officers.

${ }^{126}$ RCMP officers in the Western provinces of Canada have been repeatedly rebuked for practices involving Aboriginal deaths in custody, often referred to in the media as "Starlight Tours." On more than one occasion, Aboriginal men (often homeless) have been taken out into the country and "dropped off," only to die of exposure (see Razack 2014).

${ }^{127}$ The RCMP recently called for a National Inquiry into Murdered and Missing Aboriginal women, when a leaked RCMP report revealed that 1186 Aboriginal women had gone missing or murdered in the last 30 years. The Native Women's Association tried to keep a database of those cases reported to police and had reached approximately 800 names. It should be noted that the RCMP were NWAC's main detractors in keeping this database, suggesting that they had "over inflated" the numbers (Do 2014, n. pag). 
Officers were recorded uttering racist slurs against Indigenous protesters and denying any "Indigenous claims to the land" (CBC News 2013 b, n.pag.). I present this juxtaposition to illuminate how the politics of partnership and the politics of reconciliation are used to insist that violence no longer exists or never existed between Indigenous peoples and settler institutions.

In other examples, the politics of partnership is meant to minimize the autonomy of Indigenous nations. Shelagh Rogers, a $\mathrm{CBC}$ national radio personality and Honourary Witness to the TRC, offered her gesture at the Halifax National Event to the Commission, as the Ambassador at Large for the Canadian Canoe Museum. She begins her gesture by noting that the former director of the Canadian Canoe Museum's had "many Aboriginal friends" and that many of the canoes in the museum are "Aboriginal." By advancing notions of settler innocence (Tuck and Yang 2012, 16), a distance can be created between the settler and the guilt or hostility associated with colonization through the suggestion of "Aboriginal" friends. Rogers' focus on harmonious relationships moves beyond the narrative of "self-reliance" that is often generated by therapeutic narratives, and the emphasis on Indigenous-settler relationships affirms the official "narration of Native 'community' (Rifkin 2011,173). Rogers uses the image of the canoe to introduce the notion of the Two-Row Wampum, and to summon the importance of nation-to-nation relationships.

Her recognition of the Wampum was well-received and was arguably an important intervention for a settler participant. Dale Turner (2006) states that "the main political significance of the wampum was to represent—materially—the normally binding nature of an agreement or promise. This was a way of sanctifying one's words in practice... Wampum belts were exchanged in the context of reciprocity and renewal — two concepts of Iroquoian thought—which meant that normative terms of political agreement were renewed in the context of peace, respect, and friendship" (47). Yet, the symbol of the Two-Row Wampum is immediately followed by Rogers' 
reading of a poem, entitled Re-canoe-conciliation, written by the Executive Director of the Museum, James Raffan. The poem reads:

First of all, before. Before in this nation of rivers the canoe, a gift from the land, brought people side-by-side, Aboriginal and non-Aboriginal, in the same boat pulling together from sea to sea to sea.

Now in this nation that cries out for healing the canoe, a gift of First Nations, holds the same promise, Aboriginal and nonAboriginal, in the same boat pulling together from sea to unity.

Then, in a nation renewed, the canoe we build together will carry out past and remind us as Canadians that being in the same boat pulling together opens new horizons (Atlantic National Event Transcript 584-5).

The poem uses the trope of the canoe to cultivate an imagined historical moment where Indigenous peoples and settlers were at peace, a moment which can be re-created through the reconciliation process. ${ }^{128}$ While the poem asserts a narrative of sovereignty by addressing the two canoes, at the conclusion of the poem the characters are in the same boat, which erases the reference to selfdetermination that the image of two canoes side-by-side represents. Quoting Akwesasne Grand Chief Michael Mitchell, the wampum belt is described as having a bed of white beads and two rows of purples beads (Turner 2006, 48). The organization of the beads has great significance:

The two rows symbolize two paths or vessels, travelling down the same river together. One, a birch bark canoe, will be for the Indian people, their laws, their customs and their ways. The other ship, will be for the white people and their laws, their customs and their ways. We shall each travel the river together, side by side, but in our boat. Neither of us will try to steer the other's vessel. (Mitchell quoted in Turner 2006, 48)

\footnotetext{
128 In another presentation an Elder, Elsie Charland from Cold Lake, Alberta (Dene) and a non-Aboriginal woman named Anne Taylor, show a video depicting a healing program. Taylor states "I just want to say that Elise and I stand here as evidence of what reconciliation can create. She's like a mother to me and I'm blessed, deeply, as a nonAboriginal person to be able to stand with her as-, with deep respect and gratitude, and we want to let you know that our process is what is creating, for us, a partnership, a new conversation and a new possibility for the future" (Atlantic National Event Transcript 2011, 588). The video depicts many first person narratives describing one's healing journey and ends by playing "Love Can Build a Bridge."
} 
Given that self-determination is so deeply linked to land and territory, the fact that the poem ends with the vision of sharing space neglects the history of violence the poem is purportedly trying to address, while at the same time dismissing the importance of sovereignty that is at the crux of the wampum narrative.

In this section, I have argued that settler expressions of reconciliation are often deployed as a means to obscure the ongoing machinations of settler and neoliberal projects. This tactic has been labelled "reparation displacement" (James 2009) and can be used to bolster investment discourse, and is circulated as a means to contain demands for decolonization and restitution which are seen as threats to the nation-state and corporate investment.

\section{Forgetting Partnership}

In the preceding section I problematized the politics of partnerships as a key discourse akin to investment. The mainstream conceptualization of partnership stabilizes ongoing settler and neoliberal projects which legitimize and protect processes of settlement in Canada. Nonetheless, beneficial and respectful partnerships are not impossible and, as the wampum narrative demonstrates, are sometimes even necessary. What I am suggesting is that it is the framework under which these partnerships are constructed that requires analysis. The partnerships I examine in the previous section are constructed through settler and neoliberal values. On the other hand, partnerships established by Indigenous participants in the Truth and Reconciliation process have proven to reveal practices of containment in the Indian Residential Schools Settlement Agreement and the ongoing colonization of Indigenous peoples. I assert that these partnerships are conceived within the framework of a politics of strategic partnerships.

In an FYI page on the Aboriginal Affairs and Northern Development website, there is a page dedicated to "Gestures of Reconciliation." The AANDC response to the question: "will the 
government provide a gesture of reconciliation at every event?" was: "Reconciliation is something that is very important to the Government of Canada and we will continue to examine ways in which we can promote reconciliation and move forward in partnership with Aboriginal people across Canada, not just at TRC events, but whenever opportunities present" (Aboriginal Affairs 2013, n. pag.). Expressions of Reconciliation are central to establishing partnerships between the government and stakeholders in the TRC. At the Winnipeg National event in June 2010, Chuck Strahl announced that "the Harper government would ask parliament to repeal eight sections of the Indian Act that forced all [A]boriginal students to attend and allowed truant officers to forcibly remove children from their homes. The symbolic gesture of reconciliation won a round of applause from the crowd" (quoted in Green 2012, 143). Despite this gesture and many gestures that came afterward, at the Montreal Truth and Reconciliation event nearly three years later the legislation has yet be repealed officially.

On October 29, 2012, a gesture was made by Aborginal Affairs Minister John Duncan, who introduced the Harper government's pledge to install a stained-glassed window in Centre Block to commemorate the experience of former students of the residential school system. Using Commissioner Wilton Littlechild as a credible source due his being a former MP, Minister Duncan assures the audience that the window would be placed in a very visible place on Parliament Hill. The Aboriginal Affairs and Northern Development website states: "A permanent commemoration of the legacy of Indian Residential Schools and of the historic Apology will encourage Parliamentarians, as well as visitors to Parliament for generations to come, to learn about the history of Indian Residential Schools and Canada's reconciliation efforts" (Aboriginal Affairs 2013, n.pag.). When framed in this way, the stained glass window functions as a way to celebrate the Harper government's commitment to reconciliation and apology, almost more than as a way 
to remember the history of residential schooling. ${ }^{129}$ Since the majority of the IRSSA's negotiation took place before the Harper government was elected, and Indigenous peoples were responsible for negotiating the terms of their redress, this gestures towards scholarly speculation which interprets reconciliation as an exercise in public relations (Simpson 2012). At the end of his presentation, Minister Duncan states: "I want to close by acknowledging the former students and their families who are here with us today. I'm committed to working in partnership with First Nation, Inuit and Métis on this continuing path" (Atlantic National Event Transcripts 2011, 5701). Minister Duncan's gesture of reconciliation detailed a catalogue of the government's commitments to Indigenous peoples and the process of reconciliation.

What I find especially interesting about the stained glass window gesture is how it unpredictably played out in a live broadcast at the unveiling. The stained glass window is named Giniigaaniimenaaning (Belcourt 2012, n.pag.). The Métis artist who designed the window-a symbolic gift that would not necessarily be recognizable to Canadians, except for those who visit Parliament Hill—Christi Belcourt made an impression statement at the window's unveiling. After thanking the minister's office, the TRC and other dignitaries, she said: "The stories of residential school students were never heard in this building, so I'm going to tell you one now." As she recounted the story of Lucille Kelly-Davis, she suggested that she designed the window to reflect "hope" as opposed to "genocide":

\footnotetext{
129 The dedication of the stained glass window precedes the narration of a long list of financial investments that the Harper government has made towards ensuring the reconciliation process is a success, namely large travel grants for Indigenous survivors to attend national events. According to the AANDC website entitled "Gestures of Reconciliation", "the provision of over $\$ 1$ million to help support travel and accommodation for former students attending national events" (Aboriginal Affairs 2013, n.pag). However, upon closer inspection of the monies provided through the Advocacy and Public Information program, (most of the figures are often taken credit for twice), were actually quite minimal. For instance, on Key Milestones of Reconciliation, the website states that "Recognizing the logistical challenges for former students to travel to Inuvik, AANDC contributed $\$ 400,000$ to six northern Aboriginal organizations to support travel and accommodations for more than 170 former students to attend the Inuvik event" (Aboriginal Affairs 2013, n. pag.). This would amount to $1 / 13$ of all monies donated towards APIP "partners" being spent on 170 people attending at Truth and Reconciliation National event.
} 
I wish I could show the government that reconciliation has the potential to be so much more. I wish I could convince them that reconciliation is not an unattainable goal if there's the will and the courage to discard old paternalistic ways of thinking and of behavior. We need action and where we need action, don't meet us with silence. Where we need support, don't accuse us of being a burden. It doesn't serve anyone, it doesn't serve the country and it doesn't serve the future to put us down. We have emerged from generation after generation of assault to our sovereignty as nations and our dignity as human beings. (Belcourt 2012, n. pag.)

The importance of taking up affective strategies as part of a politics of decolonization is highlighted by Eve Tuck (2009) who argues "that a desire-based framework is an antidote to damage-centred research" (416). An analytic framework based on a politics of love works as just such an antidote because it "stops and counteracts the effects of a poison, and the poison I am referring to here is not the supposed damage of Native communities, urban communities, or other disenfranchised communities but frameworks that position these communities as damaged" (Tuck $2009,416)$. What is brought to the fore in these and other texts by Indigenous feminists is an affirmation of the relationship between feeling and self-determination, particularly through the emotion of love (Baker 2005). The politics of feeling is, in this sense, much less akin to the politics of partnership and importantly focuses on establishing Indigenous self-determination.

At the Halifax event, Expressions of Reconciliation by settlers/settler organizations were intermittently made along with Indigenous expression of reconciliation. Likely, in an attempt to engender a certain degree of "parity," settler expressions were generally followed by Indigenous expressions of reconciliation. Following the presentation by the RCMP, Shirley Flowers from Nunasiavut gave her gesture of reconciliation. She told the audience that, in order for reconciliation to be understood by all and "to regain a prominent place in our country, Aboriginal people have to reclaim or get back the leadership and the affairs of our Nations. And this implies that, if we have to work to get back something, somebody has to let go" (Atlantic National Event Transcript 2011, 579). Many survivors from Nunatsiavut have been excluded from the IRRSA in terms of 
compensation and health supports, but the TRC has enabled them to secure funding to attend events through the deployment of travel grants through APIP funds. As the delegation from Nunatsiavut took the stage, the audience was immediately reminded of the problematic and unjust exclusion of certain survivors from the IRSSA. Social and Health Minister of the Nunatsiavut Government, Patricia Kemuksigak, stated:

I would like to submit things into the Bentwood Box. There's three green documents. There are legal documents that were prepared by the Nunatsiavut Government and they're entitled, "The Request by the Government of Nunatsiavut to Add Additional Schools to the List of Recognized Residential Schools," and, "Schedule F," and they were submitted in 2007 and 2008. They were both rejected by the federal government but we would still like them to be submitted into the Bentwood Box so they will be a part of the national archives of the Truth and Reconciliation permanently so people will know our plight. I would like to also submit our video that was produced in Hopedale, Nunatsiavut entitled, "The Courage to Remember" (...) These items will now be a permanent record of the Labrador Inuit experience and will be part of the National Research Centre. We all need to stand together - and I'm glad that we're all here together - and we all need to stand together so that the Labrador experiences of Residential Schools are acknowledged, recognized, and we too have an apology of the injustices that happened in the Residential Schools. Our trauma, abuses and losses in Residential Schools are real, true, and we need that acknowledgment. (Atlantic National Event Transcript 2011, 600-601)

Following the presentation of materials for the Bentwood Box, the entire Nunatsiavut delegation was invited onto the stage, where they proceeded to sing a hymn in Inuktitut. While starting off discretely and quietly, after each verse the song became louder and more powerful. This was one of the most moving expressions of reconciliation that I have ever witnessed. It is also an example of how the TRC can be used to contest the exclusionary practices of reconciliation compensation, reminding all those who attend that reconciliation—or at least the appeals to it—have been applied unevenly.

The IRSSA's multi-pronged approached can be used to create opportunity for those who have been excluded from material reparations such as compensation. For instance, the mandate of the Truth and Reconciliation Commission stipulates that the Commission will host seven national 
events and attempt to visit every region of the country. A document addressed to the Nunatsiavut Government from Health Canada suggests that

the service gap [between AHF and $\mathrm{HC}$ ] is particularly concerning in light of up-coming Truth and Reconciliation Commission (TRC) events in which the Labrador Inuit-Day School scholars and their families will be invited to participate. It is possible that these events may re-traumatize some individuals who are still engaged in the process of healing. As such, HC's RHSP will provide mental health and emotional support services at events for participants include the Labrador Inuit, however, services will not be made available for this group before of after the events. (HC Document-Nunatsiavut Gov obtained through ATIP)

In 2012, I contacted an employee of the Health Unit in the Nunatsiavut government and during this phone interview, I learned that in November 2011 Health Canada monies were provided for a Resolution Health Support Worker, because under the provisions of the IRS RHSP, follow-up counselling is required for former residential school student who had attended TRC events. In addition, through an application to the Advocacy and Public Information Program, a group of people from the Nunatsiavut region were able to send a delegation of 23 participants (to the Inuvik National event) and 28 participants (to the Halifax National Event), despite their exclusion. Two community events were held in the Nunatsiavut region in the Fall of 2011, one in Hopedale and one in Happy Valley-Goose Bay. ${ }^{130}$ As the TRC exercises and fulfills its mandate, a door has been left open to communities that had recently lost healing funds due to the closure of the AHF in March 2010. It should be made clear that only one position was funded and while the Nunatsiavut government was given the funds to pay the salary of the Resolution Health Support Worker (who now resides in Happy Valley-Goose Bay), the transportation funding-only provided to those former students who are eligible under IRSSA provision-leaves those living in remote communities, or those who choose to receive their counselling on the land, at a stark disadvantage when it comes to obtaining health supports or counselling.

\footnotetext{
${ }^{130}$ According to my interviewee, she estimated that approximately 40-60 Survivors attended each of these events.
} 
The Expressions of Reconciliation that were described in this section offer an alternative to the market-driven conceptualizations of partnership. By asserting the need for decolonized partnerships, the Expressions of Reconciliation are also used to critique dominant structures by revealing inequitable Indigenous-settler relationships bolstered by modes of containment and the desire for surplus return (both affective and material). The establishment of strategic partnerships are necessary to fill the gaps of reparations and reconciliation administered by settler law.

\section{Conclusion}

In this chapter, I argue that the Truth and Reconciliation Commission of Canada must struggling with how to incorporate settler-Canadian participation in their programming in a meaningful way. Some scholars have demonstrated how settler engagement in reconciliation events can contribute to the decolonization of Indigenous-settler relations (Regan 2010). Nonetheless, this chapter has also identifies how decolonial goals risk being bypassed when an appeal to settler participants is routinely emphasized by reconciliation institutions. In previous chapters, I emphasize how affect has exacted bureaucratic controls over bodies and individual through the law, however in this chapter, I examine how testimony can be used to re-frame histories of violence and to legitimize ongoing unequal relationships. In particular, the conflation of emotions with capitalist rhetoric routinely structures settler "expressions of reconciliation" to emphasize the need for Indigenous-settler partnership. At the same time, I explored how powerful emotions strategically enacted dissent from dominant and elite values in different contexts when expressed and circulated by Indigenous participants.

The Expressions of Reconciliation programming at the Truth and Reconciliation National Events foregrounds settler participation and emphasizes communicative exchange. What the Expressions of Reconciliation programming lacks is a meaningful exploration of the histories of 
violence and oppression between Indigenous peoples and their relationship to contemporary relations between government institutions and corporate bodies. The glossing over of these histories of violence devalues the accountability required to make the reconciliation process consequential, especially in regards to perpetrator culpability (see Henderson and Wakeham 2009). Moreover, in failing to connect historical and contemporary assaults on Indigenous peoples, the creation of partnerships is a central tactic for settler state's pursuit of economic investment, which has historically resulted in social and environmental degradation in Indigenous territories (Huseman and Short 2012; Preston 2013) and the dispossession of Indigenous peoples (Gordon 2010). The emphasis on partnership in the Expressions programming renders the Truth and Reconciliation Commission complicit in perpetuating celebratory narratives of partnership as a mainstay of Indigenous-settler reconciliation.

My chapter notes a contradistinction between the approaches to Expressions of Reconciliation by settler participants and by Indigenous participants. While the former is often accompanied by emotional outpouring, the strategic partnerships (or refusal of partnerships) enacted by Indigenous participants are fundamentally rooted in the request for material commitments. Therefore, I argue there is a need for further examination of how affect is exaggerated in settler expressions of reconciliation. I would like to consider how the display of emotion on the part of settler participants in the TRC forums squares with prevailing assumptions about Indigenous peoples' "irrationality," dysfunction and inability to govern themselves (see Blackburn 2012). 


\section{Conclusions: Settler Accounting}

I do not owe you a complete breakdown of my ancestry. I do not keep a blood quantum chart sketched out on my palm like crib notes for an exam. I do not have to tell you where my mother was born or what substance forms my father. I don't have to justify the place of my birth, necessarily off-reservation because my tribe has none, all of our land taken from us. I cannot stop you when your gaze searches my face, gouges out my eyes, and roughs up my cheekbones, but I don't have to respond when you offer your assessment. I don't measure my blood in pints and quarts, and I will not spill it at my feet for you (This Indian Does Not Owe You, Elissa Washunta).

In this dissertation I have examined the circulation of investment discourses in reconciliation processes, particularly in the context of reparations that have been extended through the Indian Residential Schools Settlement Agreement. In this project I have defined investment rationale as the settler state's attempt to contain and limit reparations and demand financial (and affective) returns from the process. As the basis of my analysis, I build on scholars who assert that in liberal societies reconciliation replaces restitution in the wake of historical injustice (see also Alfred 2009; Coulthard 2014; Henderson 2013; Mackey 2013; Martin 2009). Reconciliation has been theorized as a co-opted project that benefits the settler state more than the Indigenous peoples it is designed to redress (Green 2012; Henderson and Wakeham 2009; Turner 2013; James 2013). For instance, reconciliation processes have been theorized as a mechanism to produce positive public relations for the nation-state (Blackburn 2009; Mackey 2013) or as a political process that is used to nullify Indigenous peoples' demands, grievances and resistance upon payment of reparations (Simpson 2012). While these insights are of fundamental importance to my work, I assert the endgame of reconciliation operationalized by the settler state is the assimilation of Indigenous peoples into a neoliberal Canada.

I have identified the way that investment rationale has been deployed by Indigenous peoples and progressive organizations to ensure accountability for historical and ongoing acts of injustice and oppressive policies directed towards Indigenous peoples. I then traced how the settler state has reframed these demands within market relations and neoliberal ideology to avoid 
culpability (see also Regan 2010). For this reason, I theorize investment as a pervasive rationale that has no particular point of origin but is primarily beneficial to state and corporate powers. The machinations of investment rationale are revealed in my analysis of accounting practices, the imposition of audits and the valorization of partnership. The application of these techniques and the circulation of these discourses are deployed under the auspices of accountable restitution, transparency, consultation and equitable power relations, but in fact, are mobilized by state and corporate authority to block the extension of Indigenous jurisdiction and the affirmation of the nation-to-nation relationship. In this sense, investment rationale is operationalized as a settler and neoliberal governmentality whose primary objective is to disguise the power of the settler state.

As I noted in the Introduction, the bureaucratic character of genocidal and colonial policies has been well-documented (see Neu and Therrien 2003; Blackburn 2005; Woodward 2009) and the extension of monetary reparations has come to signify justice. For this reason, I argue that the law as a bureaucratic purveyor of reparation payments is particularly susceptible to investment rationale.

\section{Rule of Law}

One of distinguishing factors of liberal democratic governance is the approach to conflict resolution. There is pervasive condemnation of public violence in liberal societies, and therefore, conflict is primarily negotiated and managed by the rule of law. Legal processes function as wellpracticed and universal procedures upheld to extend reparation and punishment with impartiality. In Canada, Indigenous peoples have often used the law as a tool to affirm the right to territory, resources and jurisdiction, often benefitting from legal resolutions far more than from political negotiations (see Tomiak 2011). In this dissertation I have challenged the assumption that the law is immune to the influence of settler and neoliberal projects. In fact, I assert that the very basis of Canadian law rests on colonial and racist doctrine. For this reason, I have explored how the law 
both disciplines subjects and is itself disciplined by public policy and political practices. I have documented how these forms of discipline are enacted towards individuals, organizations, and social relations writ large.

This assessment of the law is of particular importance to the reconciliation process in Canada and the extension of reparations through the Indian Residential Schools Settlement Agreement. In particular, I take issue with Diane Nelson's (2015) statement that reparations function as a "one-way valve" where monies flow to recipients of harm and violence. Instead, my analysis of investment rationale reveals the perpetrator's demand for "return" from the reparative process. I argue that strategies of containment, the "control" of organizational investments, and the creation of compensatory categories are direct pathways through which the settler state achieves a return on reparative investments. Yet, I have also documented how investment rationale has been employed indirectly through compensation processes by categorizing Indigenous peoples as dysfunctional or pathological and wage employment as emancipatory, imposed extensive auditing of Indigenous voluntary organizations under the guise of common-sense governance and, by observing how quasi-judicial commissions appeal to elite interests. The common denominator amongst all of these disciplinary tactics is a conflation of accounting and accountability.

\section{Accounting and Accountability}

The demand for accountability is linked to the process of democratization whereby decision-making and public spending is open to the scrutiny of the public. Yet, under the Harper Government, a political party that was elected on promises of transparency, increasingly Canadian citizens were rendered transparent and the government was rendered more opaque. Nowhere is this more obvious in the context of settler colonialism than it is in the imposition of the First Nations Transparency Act that reached Royal Assent in 2013, and has most recently been revoked 
by the incoming Liberal Government. ${ }^{131}$ Historically, Indigenous peoples have routinely been presented as delinquent communities incapable of governing themselves, and ultimately, as wasting taxpayer money. These beliefs continue to be circulated by the settler state despite the 2011 Auditor General's Report which indicated that Indigenous communities and services were some of the most highly regulated and highly scrutinized in the country. These assumptions were taken up by the Harper Government to legitimize the imposition of this legislation. The First Nations Transparency Act is but one example of the settler state's imposition of investment rationale (see Henderson 2012). I have demonstrated in this dissertation how the settler state has consistently operationalized a reversal of accountability in the context of "governing" Indigenous peoples. Through the legal process, Indigenous claimants are subjected to the politics of doubt while colonial violence is left unexamined; Indigenous organizations are subjected to intense scrutiny while government programs continue in perpetuity without evaluation; and partnerships are celebrated and at times, imposed without recognition of inequitable power dynamics embedded within them. Claims of historical violence resulting in a documented debt to Indigenous peoples (see RCAP Final Report 1996) are reformulated to require Indigenous peoples to be accountable for reparations received.

\footnotetext{
131 The First Nations Financial Transparency Act requires that 581 First Nations, defined as an Indian band under the Indian Act, make their audited consolidated financial statements and a Schedule of Remuneration and Expenses of chief and council available to their members as well as publish it on a website. These financial documents include:

- $\quad$ audited consolidated financial statements

- $\quad$ the Schedule of Remuneration and Expenses

- $\quad$ the auditor's written report respecting the consolidated financial statements

- the auditor's report or the review engagement report, as the case may be, respecting the Schedule of Remuneration and Expenses

Furthermore, starting in 2014-2015 and in compliance with the legislation, the Minister of Indigenous and Northern Affairs is now required to publish, on the departmental website, the audited consolidated financial statement and the Schedule of Remuneration and Expenses of chief and council for each First Nation, when received (Aboriginal Affairs 2015, n. pag.).
} 
In this dissertation I have argued that the conflation of accountability with accounting mechanisms through the law and public policy has contributed to the consolidation of settler and neoliberal projects and reinforced the power of the state. Nonetheless, on June 2 2015, the CBC released an article, entitled "Truth and Reconciliation Commission: By the numbers," which covers the reported findings of the Commission's final report. The article breaks down the history of residential schooling through categories and calculations regarding the character and administration of the residential school system. ${ }^{132}$ Following this, the article provides ratios for the possibility of student deaths, ${ }^{133}$ and then a series of numbers concerning the receipt of compensation is provided, ${ }^{134}$ as well as a summary of the performance of the Truth and Reconciliation Commission itself. ${ }^{135} \mathrm{I}$ draw attention to this article by Canada's national broadcaster because alongside the deployment of numbers there is minimal analysis of the numbers, or any indication as to why these categories were chosen. I argue that this article illustrates the pervasiveness of the assumption that numbers "speak for themselves" by bearing witness to pain and verifying the need for reparations. More importantly, the $\mathrm{CBC}$ article merely followed the format of the Truth and Reconciliation Commission's multi-volume Final Report (2015). Throughout these volumes, statistics are routinely placed alongside former student testimony to document the pain of residential schooling and its intergenerational legacy.

\footnotetext{
${ }^{132}$ Categories included: "total number of schools over time"; "peak number of schools operating at the same time", share of schools operated by the various churches; number of children in the schools and the estimated student deaths at residential schools.

133 Categories are: "odds of a student dying over the life of the program" and "odds of a residential school student dying in the early years of the program".

${ }^{134}$ This categories include: "Claims resolved by the independent assessment process", "claims in progress", "total compensation paid", "share of claims for compensation for abuse compared to the number of former students who were eligible to make such claims".

135 The following categories were included "the number of statements received by the TRC, number of national events", "hours of recorded testimony", and the "number of recommendations."
} 
As the most visible component of the Indian Residential Schools Settlement Agreement and as the most definitive archive of residential schooling available to settler-Canadians, I believe that this juxtaposition of cold statistics and emotional testimony requires further problematization. To engage in further research, I suggest that the very basis of the final report-i.e. counting and accounting methodologies—-should be interrogated, especially considering the failure of other Truth Commissions (South African Truth Commission Final Report 1996; Guatemala: Memory of Silence 1999) to enact structural change through similar numerical methodologies. It is also important to revisit the shortcomings of the methodology used by the Royal Commission of Aboriginal Peoples. Interviews with higher-ranking members of the Truth and Reconciliation Commission about this methodological approach would be instructive, as would a thorough examination of witnessing and testimony literatures alongside accounting literatures. Important questions include: How do numbers bear witness to trauma? Are numbers deployed to signify trauma in this context because it is a familiar vocabulary, used by appeal to settler elites?

\section{Appealing to Settler Elites}

In this project I have documented how reconciliation processes have been designed to appeal to settler elites. As an exercise in legitimizing for the taxpayer the extension of reparations to Indigenous people, reconciliation processes work to construct Indigenous subjects as damaged or dysfunctional, and therefore, costly to the state. One alternative to such narratives of dysfunction was the Idle No More movement that began at the end of 2012. I address how this resistance movement, which refused to appeal to settler and elite interests by situating the settler state's practices as costly and destructive, drew substantive media attention and settler allies to Indigenous causes. While residential schooling and its legacy was not absent from the movement's discourse, 
the ongoing economic exploitation of Indigenous peoples was foregrounded by its leaders and supporting activists. The Idle No More Manifesto (2012) states:

The state of Canada has become one of the wealthiest countries in the world by using the land and resources. Canadian mining, logging, oil and fishing companies are the most powerful in the world due to land and resources. Some of the poorest First Nations communities (such as Attawapiskat) have mines or other developments on their land but do not get a share of the profit. (n. pag.)

While the manifesto may not be an outright rejection of economic development or the accumulation of capital, the movement prioritizes environmental sustainability and Indigenous sovereignty over the prospects of extracting and "sharing" resources for economic gain. This means that the conflation of economic development with reconciliation and partnership was revealed as a less than ideal goal.

The Idle No More movement was initiated by four Saskatoon-based First Nations activists: Sheela McLean, Sylvia McAdams, Nina Wilson, and Jessica Gordon. This movement, along with Attawapiskat Chief Theresa Spence's well-publicized Ottawa protest, gained public traction very quickly. While Spence's hunger strike and Idle No More remained independent movements, the ideas and issues addressed by these respective leaders began to dovetail at many junctures. In addition to protesting the Omnibus bills, the movement fought for the "stabilization of emergency situations in First Nations communities such as Attawapiskat, accompanied by an honest, collaborative approach to addressing issues relating to Indigenous communities and selfsustainability, land, education, housing, healthcare, among others," and "a commitment to a mutually beneficial nation-to-nation relationship between Canada, First Nations (status and nonstatus), Inuit, and Métis communities based on the spirit and intent of treaties and a recognition of inherent and shared rights and responsibilities as unique and equal partners" (Kino-nda-niimi 
Collective 2014, 22). ${ }^{136}$ The INM movement employed various political strategies, from critical pedagogical engagement through teach-ins to direct action such as hosting rallies, blockades, flash mobs and round dances in public spaces. ${ }^{137}$

On January 2013, an editorial by Lloyd Axworthy, President of the University of Winnipeg, and Wab Kinew, Director of Indigenous Inclusion at the same university, appeared in The Globe and Mail responding to the INM movement's protests and direct action. Writing as Indigenous and non-Indigenous allies, the piece warned Canadians "not to get too caught up in the bickering [over the movement's meanings] to ignore the broader opportunity that Idle No More offers us: the chance to engage in nation-building, to make the country we love stronger. Canada's future is strongly tied to the well-being of its indigenous peoples [sic]" (n. pag. emphasis mine). The authors' imagination of Canada's future as a strong nation-state, with recognition of equitable standards for all its citizens, is a meaningful gesture. At the same time, they note:

Some Canadians may fear that they'll be worse off or face a higher tax burden if indigenous people do better. But the nation's well-being is not a zero-sum game. Right now, there are thousands of young indigenous people who face much longer odds on the road to success than the average child. If we help them better fulfill their potential, they'll eventually contribute more to our society. As the first peoples do better, we'll all do better. (Axworthy and Kinew 2013, n. pag.)

\footnotetext{
${ }^{136}$ Chief Theresa Spence began a hunger strike on December 11, 2012 to force a meeting with Prime Minister Stephen Harper and Governor-General David Johnson to re-open discussion around Canada's treaty relationship so that socio-economic disparities between Indigenous and non-Indigenous peoples could be addressed. Prime Minister Harper's refusal to meet with Spence bolstered support for the already growing Idle No More protests from Indigenous peoples and settler allies across Canada and around the world surrounding the passing the Omnibus Budget Bills. Indigenous peoples' marginalization from legal, economic and political decision making has led to institutional and grassroots social movements to address both pressing and long-term issues. Therefore, while Idle No More represents an emergent movement, it also remains part of a longer trajectory of organized Indigenous contestation of state policies.

137 Political sites such as Parliament Hill or provincial legislatures were not the only public locations targeted for direct action as shopping malls were key areas to hold public round dances. These demonstrations functioned as sites of consciousness-raising that also lead to the peaceful disruption of commerce during the busy Christmas season.
} 
The quote reformulates settler indebtedness through the language of investment. Axworthy and Kinew (2013) appear to be sensitive to the assumptions that settler-Canadians are threatened by restitution and redistribution, and they encourage settlers to recognize that "Indigenous people are standing up for themselves, but they're also standing up for the benefit of all Canadians" (n. pag.). This statement is reminiscent of the Royal Commission of Aboriginal Affairs recommendations that advocated for a social investment in Indigenous communities as a means to benefit the entire nation-state through a reduction of conflict and economic costs.

The above statement by Kinew and Axworthy, two well-known advocates for Indigenous rights, demonstrates the pervasive reach of investment rationale within the reconciliation process - and the popular imagination — in Canada. Throughout this dissertation I have examined how relations, and more accurately reparations, are changed fundamentally through the incorporation of settler participation. My contention is that Idle No More was able to demonstrate a possible pathway to the realization of decolonial change. Nonetheless, the power of settler authority operates in numerous, shape-shifting ways. What is necessary is both the assertion of Indigenous demands but also the disclosure of settler authority through explorations of the myriad ways that it is operationalized and mobilized in the public sphere. Ultimately, the appeal to settler elites is a failing endeavor and hastens the co-optation and re-articulation of much needed decolonial ideals and strategies. The need to make settler "comfortable" with decolonization and the extension of jurisdiction (see also Mackey 2014; Bell 2008) is a fallacy given the history of injustice and violence and experienced by Indigenous peoples. For true reconciliation to take place, it must be accompanied by substantive reparative strategies designed to produce material equity and the conditions for the extension of Indigenous jurisdiction. 


\section{APPENDIX A: Interview Chart}

\begin{tabular}{|c|c|c|}
\hline Date & Organization & Length \\
\hline December 9, 2010 & $\begin{array}{l}\text { Voluntary health sector } \\
\text { organization, }\end{array}$ & $1 \mathrm{hr} .4$ minutes \\
\hline January 12,2011 & Voluntary health sector, male & 36 minutes \\
\hline January 26, 2011 & $\begin{array}{l}\text { Government of Canada, } \\
\text { female }\end{array}$ & 43 minutes \\
\hline February 2, 2011 & $\begin{array}{l}\text { Voluntary Indigenous } \\
\text { organization, female }\end{array}$ & 33 minutes \\
\hline March 25, 2011 & Government of Canada, male & 41 mins. \\
\hline August 16, 2011 & $\begin{array}{l}\text { Government of Canada, } \\
\text { female }\end{array}$ & $1 \mathrm{hr} .40$ minutes. \\
\hline October, 62011 & $\begin{array}{l}\text { Indigenous Voluntary Sector, } \\
\text { male }\end{array}$ & 43 minutes \\
\hline November 9, 2011 & $\begin{array}{l}\text { Indigenous Voluntary Sector, } \\
\text { Female }\end{array}$ & 41 mins. \\
\hline October 24,2012 & $\begin{array}{l}\text { Indigenous Government } \\
\text { Representative, Female }\end{array}$ & 18 mins. \\
\hline
\end{tabular}




\section{References}

Abele, Frances. 2007. "Between Respect and Control: Traditional Indigenous Knowledge in Canadian Public Policy" in Michael Orsini and Miriam Smith (eds.), 233-256. Critical Policy Studies: Contemporary Canadian Approaches. Vancouver: UBC Press.

Aboriginal Affairs and Northern Development Canada. 2012. "Remembering the Past: A Window to the Future". 26 November 2012.

$<$ http://www.aadnc-aandc.gc.ca/eng/1332859355145/1332859433503>

- 2013. "Frequently Asked Questions: Canada's Gestures of Reconciliation"

Last updated: 27 Mar 2014.

$<$ http://www.aadnc-aandc.gc.ca/eng/1314831168708/1314831372522>

-

$2013<$ http://www.aadnc-aandc.gc.ca/eng/1332953263668/1332953559387\#y2011> -2015. "First Nations Transparency Act", Last Updated: 18 Dec 2015

$<$ https://www.aadnc-aandc.gc.ca/eng/1322056355024/1322060287419>

----------. 2016. "Statistics on the Implementation of the Indian Residential Schools

Settlement Agreement", Ottawa: Aboriginal Affairs and Northern Development. Last Updated: March 21, 2016.

$<$ https://www.aadnc-aandc.gc.ca/eng/1315320539682/1315320692192>

Aboriginal Healing Foundation. "About Us" http://www.ahf.ca/about-us

Foundation. 1999. Program Handbook, $2^{\text {nd }}$ Edition. Ottawa: Aboriginal Healing 2008. From Truth to Reconciliation: Transforming the Legacy of

Residential Schools. Marlene Brant Castellano, Linda Archibald, Mike DeGagne (eds.) Ottawa: Aboriginal Healing Foundation.

------- 2009. Response, Responsibility, and Renewal: Canada's Truth and

Reconciliation Journey. Gregory Younging, Johnathan Dewar, Mike DeGagne (eds.) Ottawa: Aboriginal Healing Foundation.

Co10. The Indian Residential Schools Settlement Agreement's Common Experience Payment and Healing: A Qualitative Study Exploring Impacts on Recipients. Ottawa: Aboriginal Healing Foundation.

------------ 2011. Cultivating Canada: Reconciliation through the Lens of Cultural Diversity. Ashok Mathur, Jonathan Dewar and Mike DeGagne (eds.) Ottawa: Aboriginal Healing Foundation.

Aboriginal Peoples' Television Network. 2011. "Kelly Busch: Residential School Students Say They've Been Hurt by Law Firm", 29 November 2011.

$<$ http://aptn.ca/news/2011/11/29/kelly-busch-residential-school-students-say-theyve-been-hurtby-residential-school-2/>

Adelson, Naomi. 2000. "Re-Imagining Aboriginality: An Indigenous Peoples' Response to Social Suffering", Transcultural Psychiatry 34, (1): 11-34

Ahmed, Sara. 2005. "The Politics of Bad Feeling," Australian Critical Race and Whiteness Studies Association Journal 1, (1): 72-84.

Alberta Justice and Solicitor General. 2016. "Process of Justice in Civil Law". Edmonton: Justice and Solicitor General of Alberta.

$<$ https://justice.alberta.ca/programs_services/public_education/Pages/civil law.aspx $>$

Alfred, Taiaiake. 2005. Wasase: Indigenous Pathways to Freedom. Toronto: University of Toronto Press. 
-2009 a. "Restitution." Eds. G Younging, J Dewar, M DeGagné, Response, Responsibility and Renewal: Canada's Truthand Reconciliation Journey, 179-191. Ottawa: Aboriginal Healing Foundation.

----------2009 b. "Colonialism and State Dependency" Journal of Aboriginal Health 5, (2): 4260 .

Alfred, Taiaiake and Jeff Corntassel. 2005. "Being Indigenous: Resurgences against Contemporary Colonialism", Government and Opposition 40, (4): 597-614.

Amagoalik, John. 2012. "Reconciliation or Conciliation: An Inuit Perspective" in Mike Degagne, Sheila, Jonathan Dewar (eds) Speaking My Truth: Reflections on Reconciliation \& Residential Schools Ottawa: Aboriginal Healing Foundation.

Angel, Naomi. 2011. "Before Truth: The Labors of Testimony and the Canadian Truth and Reconciliation Commission", Culture, Theory and Critique 53 (2): 199-214.

Ashton, C.W. and D. Duffie-Ahston. 2008. "Achieving Equity in Aboriginal Healthcare Resource Allocation: The Case for a Formula Approach", Bancroft: Ontario Metis Family Records Center.

Assembly of First Nations. 1994. Breaking the Silence: An Interpretive Study of Residential School Impact and Healing as Illustrated by the Stories of First Nations Individuals. Ottawa: Assembly of First Nations.

--- 2004. Report on Canada's Dispute Resolution Plan to Compensate for Abuses in Indian Residential Schools. Ottawa: Assembly of First Nations.

-----------. 2009. Mental Health Addictions Indian Residential Schools Update. Ottawa: Assembly of First Nations.

------.-. 2010 a. "Resolution 6/2010" Annual General Assembly, Winnipeg, July 2010.

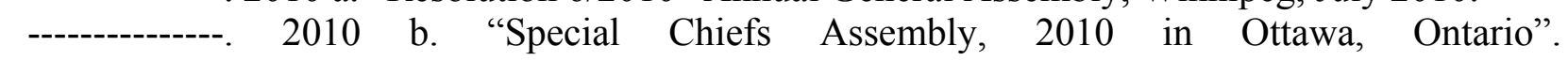
$<\mathrm{http} / / /$ www.afn.ca/en/special-chiefs-assembly-2010>

--------. 2011. Assembly of First Nations Annual Report: Honouring Our Traditions: Achieving Action for our Future, 2011-2012. Ottawa: Assembly of First Nations.

----- 2012 a. Crown-First Nations Gathering Backgrounder. $<$ http://www.afn.ca/en/newsmedia/latest-news/crown-first-nations-gathering-backgrounder>

-----------2012 b. "Prime Minister Harper's address to the Crown-First Nations' Gathering".

$<$ http://www.afn.ca/uploads/files/cfng/pm-cfng.pdf $>$

----. 2012 c. Assembly of First Nations Annual Report 2011-12. Ottawa: Assembly of First Nations.

------. 2015. "Fact Sheet: Personal Credits for Education”, Ottawa: Assembly of First Nations.

$<$ http://www.afn.ca/uploads/files/afn_personal_credit_fact_sheet_january_2015.pdf $>$

Atleo, Shawn. 2012. "The Economics of Reconciliation", Speech Given to The Canadian Club, Toronto April $23 \mathrm{http}: / / \mathrm{www}$. afn.ca/uploads/files/nc/notescdnclub.pdf

----------. 2013. "Resources, Risks, and Responsibilities: A First Nations Perspective on Canada's Resource Agenda" Speech given at the Vancouver Board of Trade, 27 Sept 2013. Axworthy, Lloyd and Wab Kinew "Canada's Future: Let's Be Divided No More" The Globe and Mail 11 Jan 2013. < http://www.theglobeandmail.com/globe-debate/canadas-future-letsbe-divided-no-more/article7199421/>

Baker, Emerance. 2005. "Loving Indianess: Native Women's Storytelling as Survivance", Atlantis: Critical Studies in Gender, Culture and Social Justice 29, (2): 111-121 
Bambra, Clare. 2011. Work, Worklessness and the Political Economy of Health. Oxford: Oxford University Press.

Battiste, Marie. 2000. "Maintaining Aboriginal Identity, Language and Culture," Reclaiming Indigenous Voice and Vision. Ed. Marie Battiste, 192-208. Vancouver: UBC Press.

Barkan, Elazar. 2001. The Guilt of Nations: Restitution and Negotiating Historical Injustices. Baltimore and London: The Johns Hopkins University.

Baxter v. Canada. 2006. Charles Baxter Sr. \& Elijah Baxter et al. v. Attorney General of Canada et al. Ontario Superior Court of Justice court file no 00-CV-192059CV, December 15, 2006 (26 p). Winkler J.

Bay, Michael. 2013. “An Experiment in Therapeutic Jurisprudence: Reflections on the Residential Schools Compensation Process" Journal of Ethics in Mental Health 8, (1): 1-5.

Beauchamp, Paula. 2007. "First Nations targeted by markets; Retailers see windfall in residential school payouts" Ottawa Citizen 7 October 2007

Bell, Avril. 2008. "Recognition or Ethics?: De/Centering and the Legacy of Settler Colonialism", Cultural Studies 22, (6): 850-869.

Bell, Stephen and Andrew Hindmoor. 2009. Rethinking Governance: The Centrality of the State in Modern Society. Cambridge: Cambridge University Press.

Benjamin, Bret. 2007. Invested Interests: Capital, Culture, and the World Bank. Minneapolis: University of Minnesota Press.

Berlant, Lauren. 2008. The Female Complaint: The Unfinished Business of Sentimentality in American Culture. Durham NC: Duke University Press.

----------. 2011. Cruel Optimism. Durham: Duke University Press.

Bird, Brian. 2010. 'Federal power and federal duty: reconciling sections 91(24) and 35(1) of the Canadian constitution', Policy Options: 1-4.

$<$ http://policyoptions.irpp.org/magazines/afghanistan/federal-power-and-federal-duty-

reconciling-sections-9124-and-351-of-the-canadian-constitution/>

Blackburn, Carole. 2005. "Searching for Guarantees in the Midst of Uncertainty: Negotiating Aboriginal Rights and Title in British Columbia", American Anthropologist, 107, (4): 586 $-596$.

2007. "Producing legitimacy: reconciliation and the negotiation of Aboriginal rights in Canada", Journal of the Royal Anthropological Institute 13, (3): 621-638

2012. "Culture Loss and Crumbling Skulls: The Problematic of Injury in Residential School Litigation.” PoLAR: Political and Legal Anthropological Review 35, (2): 289-307.

Blaze Carlson, K. "University's residential school apology raises eyebrows," The National Post. 27 Oct 2011

$<$ http://news.nationalpost.com/2011/10/27/universitys-residential-school-apology-raiseseyebrows/>

Borrows, John. 2001. "Domesticating Doctrines: Aboriginal Peoples after the Royal Commission" McGill Law Journal. 46: 615-661

-------------. 2002. Recovering Canada: The Resurgence of Indigenous Law. Toronto: University of Toronto Press, 2002.

Bourdieu, Pierre. 1977. Outline of a Theory of Practice. Cambridge: Cambridge University Press. Bowlus, Audra, Katherine McKenna, Tanis Day and David Wright. 2003. The Economic Costs of Child Abuse in Canada. Report to the Law Commission of Canada. 
Braithwaite, John. 2002. "Restorative Justice and Therapeutic Jurisprudence", Criminal Law Bulletin, 244-262.

002.pdf>

$<$ http://www.anu.edu.au/fellows/jbraithwaite/_documents/Articles/Restorative_Justice_2

Brasfield, CR. 2001. "Residential School Syndrome" British Columbia Medical Journal 43, (1): 78-81

Brave Heart, Maria Yellow Horse, 2003. "The Historical Trauma Response among Native and Its Relationship with Substance Abuse: A Lakota Illustration" Journal of Psychoactive Drugs, 35, (1): 7-13.

Brown, Wendy. 2006. Regulating Aversion: Tolerance in the Age of Identity and Empire. Princeton: Princeton University Press.

Calgary Chamber of Voluntary Organizations. 2012. "CRA's Rule for Advocacy by Charities". Calgary: Calgary Chamber of Voluntary Organizations.

$<$ https://www.calgarycvo.org/cras-rules-for-advocacy-by-charities/>

Canada. 1983. First Ministers Conference on Aboriginal Constitutional Affairs, 1983. Verbatim Transcript.

1984. First Ministers Conference on Aboriginal Constitutional Affairs, 1984. Verbatim Transcript

1985. First Ministers Conference on Aboriginal Constitutional Affairs, 1985. Verbatim Transcript.

1987. First Ministers Conference on Aboriginal Constitutional Affairs, 1987. Verbatim Transcript.

1998 a. Gathering Strength: Canada's Aboriginal Action Plan. Ottawa: Supply and Services Canada.

-------.1998 b. Address by the Honourable Jane Stewart Minister of Indian Affairs and Northern Development on the occasion of the unveiling of Gathering Strength - Canada's Aboriginal Action Plan.

$<$ https://www.aadnc- aandc.gc.ca/eng/1100100015725/1100100015726>

---------. 2004. Strengthening the Relationship: Report on the Canada-Aboriginal Peoples Roundtable, Ottawa 19 April 2004.

--.2015. Canada Pension Plan Disability Benefit-Overview. Ottawa: Retirement and Pensions. $<$ http://www.esdc.gc.ca/en/cpp/disability/index.page>

Canadian Arctic Resources Committee. 1987. Aboriginal Self-Government and Constitutional Reform: Setbacks, Opportunities and Arctic Experiences. Ottawa: Canadian Arctic Resources Committee.

Canadian Bar Association. 2005. The Logical Next Step: Reconciliation Payments for All Indian Residential School Survivors. Toronto: Canadian Bar Association.

Canadian Executive Services Organization. 2007. Planning Your Future: Information for Managing Residential School Settlements Brochure.

Canadian Executive Services Organization. 2008. Annual Report: Building Capacity, Changing Lives 2007-2008. Toronto: CESO

Canadian Mental Health Association. Changing Directions, Changing Lives: The Mental Health Strategy for Canada. 2012. Toronto: Mental Health Commission of Canada.

Cantillon, Bea and Wim Van Lancker. 2013. "Three Shortcomings of the Social Investment Perspective", Social Policy and Society 12, (4): 553-564. 
Caruth, Cathy (ed.). 1995. Trauma: Explorations in Memory. Baltimore: Johns Hopkins University Press.

Castellano, Marlene Brant. 2006. Final Report of the Aboriginal Healing Foundation. Volume I A Healing Journey: Reclaiming Wellness. Ottawa: Aboriginal Healing Foundation.

Castellano, Marlene Brant. 2006. Final Report of the Aboriginal Healing Foundation. Volume II Measuring Progress: Program Evaluation. Ottawa: Aboriginal Healing Foundation.

Castellano, Marlene Brant. 2006. Final Report of the Aboriginal Healing Foundation. Volume III Promising Healing Practices in Aboriginal Communities. Ottawa: Aboriginal Healing Foundation.

Castellano, Marlene Brant. 2010. "Healing residential school trauma: The case for evidence based policy and community-led programs", Native Social Work Journal 7: 11-31

CBC News. 2005. "Ottawa not fully liable for residential school claims: Supreme Court”, $C B C$ News 21 Oct 2005

$<$ http://www.cbc.ca/news/canada/ottawa-not-fully-liable-for-residential-school-claims-

supreme-court-1.543349>

----------. 2009. “Indian day school survivors launch \$15B lawsuit”, CBC News 31 Jul 2009. http://www.cbc.ca/news/canada/manitoba/indian-day-school-survivors-launch-15blawsuit-1.843896

----------. 2011. "Labrador Residential School Lawsuit Approved”, CBC News 22 Dec 2011.

$<$ http://www.cbc.ca/news/canada/newfoundland-labrador/labrador-residential-school-

lawsuit-approved-1.1026425>

-----------. 2013 a. "Residential School Survivor says Compensation Process Failed him", $C B C$

News. 12 Feb. 2013.

$<$ http://www.cbc.ca/news/canada/north/residential-school-survivor-says-compensationprocess-failed-him-1.1411981>

------------2013 b. "First Nations say Reclaiming Crown land a 'desperate move"”, CBC News 01 Nov 2013.

$<$ http://www.cbc.ca/news/canada/new-brunswick/first-nations-say-reclaiming-crownland-a-desperate-move-1.2325052>

-------------. 2014. "Residential School Survivors: Education Credit a New Lesson”, CBC News 18 May 2014.

$<\underline{\text { http://www.cbc.ca/news/canada/british-columbia/residential-school-survivors-education-credit- }}$ a-new-lesson-1.2646894>

-----------. 2015. “Truth and Reconciliation Commission: By the Numbers”, CBC News. 2 June 2015.

$<$ http://www.cbc.ca/news/aboriginal/truth-and-reconciliation-commission-by-the-

numbers-1.3096185>

Centre for Human Rights Research. 2013. "Truth and Reconciliation," Winnipeg: University of Manitoba. < http://chrr.info/truth-a-reconciliation>

Cherrington, Mark. 2011. “Oh, Canada!”, Cultural Survival 31, (3): no pagination

$<$ https://www.culturalsurvival.org/publications/cultural-survival-quarterly/canada/ohcanada $>$

Chrisjohn, Roland and Sherri L. Young. 1997. The Circle Game: Shadow and Substance in the Indian Residential School Experience in Canada. Penticton B.C.: Theytus Books

Clark, David S.(ed.) 2007. "Class Action Lawsuits", Encyclopedia of Law and Society, 188-9. Thousand Oaks: Sage Publications. 
Coburn, David, Keith Denny, Eric Mykhalovskiy, Peggy McDonough, Ann Robertson, Rhonda Love. 2003. "Population Health in Canada: A Brief Critique", American Journal of Public Health 93, (3): 392-396

Coffey, Charles S. 1997. "The Cost of Doing Nothing: A Call to Action", An address by former RBC Vice-President at the Royal Bank of Canada and the Council for the Advancement of Native Development Officers Conference.

$<$ http://www.rbcroyalbank.com/commercial/aboriginal/rr-speech.html $>$

Compensation Advisory Board. 2002. Towards Redress and Recovery: Report to the Minister of Education and Science. Residential Institutions Redress Bill, 2001. Dublin: Compensation Advisory Committee.

$<$ http://www.rirb.ie/documents/cac_report2002.pdf $>$

Corntassel, Jeff. 2009. "Indigenous Storytelling, Truth-telling, and Community Approaches to Reconciliation" ESC: English Studies in Canada 35, (1): 137-159

Coulthard, Glen. 2008. "Beyond Recognition: Indigenous Self-Determination as Prefigurative Practice", Lighting the $8^{\text {th }}$ Fire: The Liberation, Resurgence, and Protection of Indigenous Nations, Leanne Simpson (ed), 187-204. Toronto: Arbeiter Ring Press. 2014. Red Skins, White Masks: Rejecting the Colonial Politics of Recognition. Minneapolis: University of Minnesota Press.

Cruikshank, Barbara. 1996. "Revolutions within: self-government and self-esteem," Foucault and Political Reason: Liberalism, Neo-liberalism and rationalities of Government. Andrew Barry, Thomas Osborne and Nikolas Rose (eds), 231-252. Chicago: The University of Chicago Press.

Cowlishaw, Gillian. 2003. "Disappointing Indigenous People: Violence and the Refusal of Help" Public Culture 15 (1): 103-125

Cvetkovich, Ann. 2003. An Archive of Feelings: Trauma, Sexuality and Lesbian Public Cultures. Durham, NC : Duke University Press.

Press.

Curry, Bill. 2011. "Cost to Redress Native Residential School Abuse Set to Pass \$5-billion”, The Globe and Mail. 18 November 2011

$<$ http://www.theglobeandmail.com/news/politics/cost-to-redress-native-residential-

school-abuse-set-to-pass-5-billion/article4251765/>

Das, Veena. 2007. Life and Words: Violence and the Descent into the Ordinary. Berkeley; London; Lost Angeles: University of California Press.

Deer, Sarah. 2004. “Towards an Indigenous Jurisprudence of Rape”, Kansas Journal of Law and Public Policy 14: 121-154.

Deibel, Linda. 2010. "No Truth, No Reconciliation for aging residential school survivors", The Toronto Star 23 July 2010

DeGagne, Mike. 2008. "Administration in a National Aboriginal Organization: Impacts of Cultural Adaptation", Canadian Public Administration 50, (4): 659-672

De Grieff, Pablo. 2006. Justice and Reparations: The Handbook of Reparations. Oxford: Oxford University Press.

De Leeuw, Sarah. 2007. Artful Places: Creativity and Colonialism in British Columbia's Indian Residential Schools. Unpublished Dissertation. Kingston: Department of Geography, Queen's University 
De Leeuw, Sarah, Emilie Cameron and Margo Greenwood. 2010. "Deviant Constructions: How Governments Preserve Colonial Narratives of Addictions and Poor Mental Health to Intervene into the Lives of Indigenous Children and Families in Canada", International Journal of Mental Health and Addiction 8, (2): 282-295

Delgado, Richard. 1997. Alternative Dispute Resolution: Conflict as Pathology: An Essay for Trina Grillo", Minnesota Law Review 81:1391-1412.

Department of Indian Affairs and Northern Development Canada. 2000. Alternative Resolution Strategies for Dealing with Residential School Claims. Ottawa: Minister of Public Works and Services.

Diabo, Russ. 2013. 'Harper Launches Major First Nations Termination Plan as Negotiating Tables Legitimize Canada's Colonialism', The Socialist Project, No 756, 2013, available at: http://www.socialistproject.ca/bullet/756.php. Retrieved: 13 April 2015.

Do, Trinh Theresa. 2014. "RCMP Confirm more than 1,000 Murdered Aboriginal Women", $C B C$ News. 2 May 2014.

$<$ http://www.cbc.ca/news/politics/rcmp-confirm-report-of-more than-1-000-murderedaboriginal-women-1.2630456>

Duggan, Lisa. 2004. The Twilight of Equality?: Neoliberalism, Cultural Politics, and the Attack on Democracy. Boston: Beacon Press.

Duran, Eduardo. 2006. Healing the Soul Wound: Counseling with American Indians and Other Native Peoples. New York, New York: Teachers College Press.

Earnscliffe and Pollara. 2000. "Residential School Survey" $<$ http://publications.gc.ca/collections/Collection/PF4-10-2001E.pdf $>$

Eng, David and David Kazanjian. 2003. Loss: The Politics of Mourning. Berkley and Los Angeles: University of California Press.

Episkenew, Jo Ann. 2009. Taking Back Our Spirits: Indigenous Literatures, Public Policy and Healing. Winnipeg: University of Manitoba Press.

Erskine, Sarah. 2011. "The Use of Matrix Settlements in Canadian Class Actions", Canadian Class Action Review 7, (1): 57-34.

Falzon, Mark Anthony. 2009. "Introduction: Multi-Sited Ethnography", in Multi-sited Ethnography: Theory, Praxis and Locality in Contemporary Research. Mark-Anthony Falzon (ed.), 1-24. London: Ashgate Publishing.

Farrow, Trevor CW. 2014. "Residential Schools Litigation and the Legal Profession", The University of Toronto Law Journal 64, (4): 596-619.

Fassin, Didier and Richard Rechtman. 2009. The Empire of Trauma: An Inquiry into the Condition of Victimhood. Princeton: Princeton University Press.

Feldthusen, B. O. Hankivsky and L. Greaves. 2000. "Therapeutic Consequences of Civil Actions for Damages and Compensation Claims by Victims of Sexual Abuse", Canadian Journal of Women and the Law 12, (1): 166-116

Ferguson, James. 2005. "Seeing Like an Oil Company: Space, Security, and Global Capital in Neoliberal Africa" American Anthropologist 107, (3): 377-382

Fiske, Jo-Ann. 2008. "Placing Violence against First Nations Children: The Use of Space and Place to Construct the (In)credible Violated Subject", Healing Traditions: The Mental Health of Aboriginal Peoples in Canada. Laurence Kirmayer and Gail Guthrie Valaskakis (eds.), 140-159. Vancouver: University of British Columbia Press.

Fontaine, Phil and Bernie Farber. 2013. "What Canada committed against First Nations was Genocide. The UN should recognize it", The Globe and Mail. 14 Oct 2013 
$<\mathrm{http} / /$ www.theglobeandmail.com/opinion/what-canada-committed-against-first-nations was-genocide-the-un-should-recognize-it/article14853747/>

Fontaine, Phil, Michael Dan and Bernie Farber. 2013. "A Canadian Genocide in Search of a Name", The Toronto Star. 19 Jul 2013.

$<$ http://www.thestar.com/opinion/commentary/2013/07/19/a_canadian_genocide_in_sear ch_of_a_name.html>

Freisen, Joe and Anne O'Neill. 2007. "Businesses take aim at native's settlement money," The Globe and Mail. Toronto: 6 December 2007.

Funk-Unrau, Neil and Anna Snyder. 2007. "Indian Residential School Survivors and state designed ADR: A Strategy of Co-optation?" Conflict Resolution Quarterly 24, (3): 285 $-304$

Furniss, Elizabeth. 1992. Victims of Benevolence: Discipline and Death at the Williams Lake Indian Residential School, 1891-1920. Williams Lake, B.C.: Cariboo Tribal Council.

Galhofer, Sonja and Andrew Chew. 2000. "Introduction: Accounting and Indigenous Peoples", Accounting, Auditing and Accountability Journal 13, (1): 256-267

Galhofer, Sonja and Jim Haslam. 2005. Accounting and Emancipation: Some Critical Interventions. Routledge Studies in Accounting. London and New York: Routledge Books.

Galloway, Gloria. 2012. "Residential school abuse claims surpass federal estimates," The Globe and Mail 23 July 2012

$<$ http://www.theglobeandmail.com/news/politics/residential-school-abuse-claims-

surpass-federal-estimates/article4436981/>

Gibson, Kathy. 2000. "Accounting as a Tool for Aboriginal Dispossession: Then and Now", Accounting, Auditing, and Accountability, 13, (3): 289-306.

Gibson-Graham, J.K. 2006. A Postcapitalist Politics. Minneapolis: University of Minnesota Press.

Gilmore, Ruth Wilson. 2007. "From Black Awakening in Capitalist America, in The Revolution Will Not Be Funded: Beyond the Non-Profit Industrial Complex. Incite! Women of Color Against Violence (Eds.) Cambridge: South End Press.

--on Should Fire Our Political Imagination", Faultlines: News and Notes from the Center for Race and Gender. Berkeley: University of California, Berkeley.

$<$ http://crg.berkeley.edu/content/life-hell-how-capitalim-aving-capitalim-capitalim-

should-fire-our-political-imagination>

Gone, Joseph. 2009. "A Community-Based Treatment for Native American Historical Trauma: Prospects for Evidence-Based Practice," Journal of Consulting and Clinical Psychology. 77, (4): 751-762.

Gordon, Todd. 2010. Imperialist Canada. Winnipeg: Arbeiter Ring Publishing.

Graeber, David. 2011. Debt: The First 5,000 Years. Brooklyn: Melville House.

Graefe, Peter. 2005. "Roll-out Neoliberalism and the Social Economy", Paper prepared for the Annual Meeting of the Canadian Political Science Association, University of Western Ontario.

Graham, John and Laura Mitchell. 2009. A Legacy of Excellence: Best Practices Board Study on Aboriginal Healing Foundation. Ottawa: Institute on Governance. $<$ http://www.ahf.ca/downloads/legacy-of-excellence-full-report.pdf $>$ 
Grandin, Greg. 2005. "The Instruction of Great Catastrophe: Truth Commissions, National History, and State Formation in Argentina, Chile, and Guatemala", The American Historical Review 110, (1): 46-67

Grant, Agnes. 1988. No End of Grief: Indian Residential Schools in Canada. Winnipeg: Pemmican Publishing.

Green, Joyce. 2001. "Canaries in the Mines of Citizenship: Indian Women in Canada," Canadian Journal of Political Science, 34, (4): 715-738.

---------. 2003. “Colonization, Decolonization and Recolonization in Canada", In Changing Canada. Political Economy as Transformation, ed. Wallace Clement and Leah Vosko, 51-78. Montreal/ Kingston: McGill-Queen's University Press.

Green, Robyn. 2012. "Unsettling Cures: The Possibilities and Limitations of the Indian Residential School Settlement Agreement." Canadian Journal of Law and Society 27 (1): 129-148.

----------------. 2014. “Recovering Space: Trauma, Education and The Lesser Blessed" Canadian Literature and Cultural Memory, 354-372. Toronto: Oxford University Press.

--------------. 2015. "The Economics of Reconciliation: Tracing Investment in Indigenous-Settler Reconciliation", The Journal of Genocide Research 17, (4): 473-493.

Greer, Susan and Chris Patel. 2000. "The Issue of Australian Indigenous World-making and Accounting", Accounting, Auditing, and Accountability 13, (3): 289-306.

Grillo, Trina. 1991. "The Mediation Alternative: Process Dangers for Women" The Yale Law Journal 100, (6): 1545-1610.

Grosfoguel, Ramon. 2007. "The Epistemic Decolonial Turn: Beyond Political Economy Paradigms," Cultural Studies 21, (2-3): 211-223.

Guterson, Hugh. 1998. "Studying Up Revisited" PoLar: Political and Legal Anthropological Review. 20, (1): 114-119.

Hage, Ghassen. 1997. White Nation: Fantasies of White Supremacy in a Multicultural Society. Canberra: Pluto Press.

Hamber, Brandon. 2000. "Repairing the Irreparable: Dealing with the double-binds of making reparations for crimes of the past," Ethnicity and Health 5 (3-4): 215-226

-------------. 2009. Transforming Societies after Political Violence: Truth, Reconciliation, and Mental Health. London: Springer Press.

Hankivsky, Olena. 2004. Social Policy and the Ethic of Care. Vancouver: UBC Press.

Harvey, David. 2005. A Brief History of Neoliberalism. Oxford: Oxford University Press.

Hayner, Pricilla. 2010. Unspeakable Truths: Transitional Justice and the Challenge of Truth Commissions. $2^{\text {nd }}$ Ed. New York: Routledge.

Health Canada. 1998. "National Native Alcohol and Drug Abuse Program Review", Ottawa: Health Canada. eng.php $>$

$<$ http://www.hc-sc.gc.ca/fniah-spnia/pubs/substan/_ads/1998_rpt-nnadap-pnlaada/index-

--------------. 2004 a. Indian Residential School Mental Health Framework. Ottawa: Health Canada.

$<$ http://www.hc-sc.gc.ca/ahc-asc/pubs/_contribution/agreement_accord/index-eng.php>

Health Canada. 2012. "Contribution Agreements", Ottawa: First Nations and Inuit Health Branch http://www.hc-sc.gc.ca/fniah-spnia/finance/agree-accord/index-eng.php

Last updated: 2015-12-22 
---------. 2013. Indian Residential School Resolution Health Support Program.

Last updated March 2013

$<$ http://www.hc-sc.gc.ca/fniah-spnia/services/indiresident/irs-pi-eng.php $>$

-2015. First Nations Mental Wellness Continuum. Ottawa: Health Canada.

$<$ http://health.afn.ca/uploads/files/24-14-1273-fn-mental-wellness-framework-

en05_low.pdf $>$

Health Council of Canada. 2011. Understanding and Improving Aboriginal and Child Maternal Health in Canada, Ottawa: Health Council of Canada.

Herman, Judith. 1992. Trauma and Recovery: The Aftermath of Violence-From Domestic Abuse to Political Terror. New York: Perseus Books.

Henderson, Jennifer and Pauline Wakeham. 2009. "Colonial Reckoning, National Reconciliation?: Aboriginal Peoples and the Culture of Redress in Canada" English Studies in Canada. 35, (1): 1-26

Henderson, Jennifer. 2012. "Transparency, Spectatorship, Accountability: Indigenous Families in Settler-State 'Postdemocracies", ESC: English Studies in Canada 38, (3-4): 299-330 (1) Child: Discursive Exchanges of (Neo)liberal Axioms in the Culture of Redress" Jennifer Henderson and Pauline Wakeham (eds).Reconciling Canada: Critical Perspectives in Canada, 63-86. Toronto: University of Toronto Press.

Henderson, Sa'ke'j. 2013. "Incomprehensible Canada", Reconciling Canada: Critical Perspectives in Canada. Jennifer Henderson and Pauline Wakeham (eds), 115-128. Toronto: University of Toronto Press.

Henderson, Youngblood and Wanda D. McCaslin. 2005. "Exploring Justice as Healing”, Justice as Healing Indigenous Ways: Writings on Community Peacemaking and Restorative Justice, Wanda D McCaslin (ed.), 3-12. St. Paul, MN: Living Justice Press.

Holder, Cindy. 2014. "Reasoning like a State: Integration and the Limits of Official Regret", in On the Uses and Abuses of Political Apologies in M. Mihai and M. Thaler (eds), 203-219. London: Palgrave Macmillan UK.

Hopwood, Anthony and Peter Miller. 1994. Accounting as Social and Institutional Practice. Cambridge studies in Management. Cambridge UK: Cambridge University Press.

Humphrey, Michael. 2005. "Reconciliation and the Therapeutic State", Journal of Intercultural Studies 26, (3): 203-220.

Hurley, Mary C. and Jill Wherrett. 2000. Report of the Royal Commission on Aboriginal Peoples. Ottawa: Library of Parliament.

$<$ http://www.lop.parl.gc.ca/content/lop/researchpublications/prb9924-e.htm>

Huseman, Jennifer and Damien Short. 2012. "A Slow Industrial Genocide: Tar Sands and the Indigenous peoples of Alberta", International Journal of Human Rights 61, (1): 216-237.

Idle No More. 2013. "Manifesto". < http://www.idlenomore.ca/manifesto>

Illouz, Eva. 2007. Cold Intimacies: The Making of Emotional Capitalism. Cambridge: Polity Press.

Indian Affairs and Northern Development Canada. 2003. Resolving Aboriginal Claims: A Practical Guide to Canadian Experiences. Ottawa: Indian Affairs and Northern Development.

< http://www.aadnc-aandc.gc.ca/eng/1100100014174/1100100014179>

Innu Comprehensive Healing Strategy. Ottawa: Minister of Public Works and Services. 
2010. Evaluation of Community-Based Healing

Initiatives Supported through the Aboriginal Healing Foundation. Ottawa: Minister of

Public Works and Services.

$<$ https://www.aadnc-aandc.gc.ca/eng/1328551234085/1328552330777>

Indian Residential Schools Adjudication Secretariat. 2011. Guide to the Independent Assessment

Process Application Guide. Guide version 3.0. Ottawa: Indian Residential Schools Adjudication Secretariat.

Adjudicator to the Independent Assessment Process Oversight Committee", Ottawa: Indian Residential Schools Adjudication Secretariat. http://www.iap-pei.ca/information/publication/pdf/pub/ar2012-eng.pdf

Ottawa: Indian Residential Schools Adjudication Secretariat. November 2013.

$<$ http://www.iap-pei.ca/us-nous/us-nous-eng.php>

Indian Residential Schools Settlement Agreement. 2006 a. "Schedule: 'J' Commemoration Policy Directive", Ottawa: Indian Residential Schools Settlement Agreement

2006 b. "Schedule: 'M' Funding Agreement between Aboriginal Healing Foundation and the Government of Canada", Ottawa: Indian Residential Schools Settlement Agreement.

----or 2006 c. "Schedule 'N": Truth and Reconciliation Commission of Canada Mandate", Ottawa: Indian Residential Schools Settlement Agreement.

Indian Residential Schools Settlement Agreement. 2006 d. "Authorized Court Agreement", Ottawa: Indian Residential Schools Settlement Agreement.

Inuit Tapiriit Kanatami. 2007. Alianait Inuit Mental Wellness Action Plan. $<$ https://www.itk.ca/publication/alianait-inuit-mental-wellness-action-plan $>$

----------. 2012. "Nunatsiavut Inuit-One Step Closer," January 18, 2012

$<$ https://www.itk.ca/blog/6/mary-simon/2012/jan/nunatsiavut-inuit-one-step-closer>

- 2012. Mary May Simon's Blog. 9 Feb 2012

Irlbacher-Fox, Stephanie. 2009. Finding Dahshaa: Self-Government, Social Suffering, and Aboriginal Policy in Canada. Vancouver and Toronto: University of British Columbia Press.

James, Matt. 2006. "Do Campaigns for Historical Redress erode the Canadian welfare state?" in Multiculturalism and the Welfare State: Recognition and Redistribution in Contemporary Democracies. Keith Banting and Will Kymlicka (eds.), 222-247. Oxford: Oxford University Press.

----one 2008. "Wrestling with the Past: Apologies, Quasi-apologies, and Non-apologies in Canada", The Age of Apology: Facing Up to the Past. Mark Gibney, Rhoda E. Howard Hassman, Jean-Marc Coicaud and Niklaus Steiner (eds.), 137-153. Philadelphia: University of Pennsylvania Press.

----------. 2009. "Scaling Memory: Reparation Displacement and the Case of BC", Canadian Journal of Political Science. 42, (2): 363-386

---------. 2013. "Neoliberal Heritage Redress", in Jennifer Henderson and Pauline Wakeham (eds). Reconciling Canada: Critical Perspectives in Canada, 31-46. Toronto: University of Toronto Press.

Jenson, Jane and Denis Saint-Martin. 2003. 'New routes to social cohesion?: citizenship and the social investment state', The Canadian Journal of Sociology, 28, (1): 77-99. 
Joseph, Miranda. Debt to Society: Accounting for Life. Minneapolis: University of Minnesota Press.

Jung, Courtney. 2009. "Canada and the Legacy of the Indian Residential Schools: Transitional Justice for Indigenous People in a Nontransitional Society" Social Science Research Network. < http://papers.ssrn.com/sol3/papers.cfm?abstract_id=1374950>

Kheraj, Sean. 2013. "The New History Wars?: Avoiding Fights of the Past", ActiveHistory.ca $<$ http://activehistory.ca/2013/05/11059/>

King, Thomas. 2012. The Inconvenient Indian: A Curious Account of Native People in North America. Toronto: Doubleday Canada.

Kino-nda-niimi Collective. 2014. The Winter We Danced. Winnipeg: Arbeiter Ringer Publishers.

Kirmayer, Laurence J. and Gail Guthrie Valaskakis (eds). 2008. Healing Traditions: The Mental Health of Aboriginal Peoples in Canada. Vancouver: University of British Columbia.

Kuokkanen, Rauna. 2006. "The logic of the gift_reclaiming Indigenous peoples' philosophies," in T. Botz-Bornstein (ed.), Re-ethnicizing the mind?: Cultural Revival in Contemporary Thought Amsterdam \& New York: Rodopi.

Ladner, Kiera L. 2006. "Indigenous Governance: Questioning the Status and the Possibilities for Reconciliation with Canada's Commitment to Aboriginal and Treaty Rights", Ottawa: National Centre for First Nations Governance.

Ladner, Kiera L. and Caroline Dick. 2008. "Out of the Fires of Hell: Globalization as a Solution to Globalization: An Indigenist Perspective" Canadian Journal of Law and Society 23, (1-2): 63-91

Ladner, Kiera and Leanne Simpson. 2010. This is an Honour Song: Twenty Years since the Blockades. Winnipge: Arbeiter Ring Publishers.

Lane, Jan-Erik. 2000. New Public Management. London and New York: Routledge Books.

Larner, Wendy. 2000. "Neo-liberalism: Policy, Ideology, Governmentality" Studies in Political Economy. 63: 6-25.

----------------. 2002. "Globalization, Governmentality and Expertise: Creating a Call Centre Labour Force”, Review of International Political Economy 9, (4): 650-674.

LaRocque, Emma. 1997. "Re-examining Culturally Appropriate Models in Criminal Justice Applications," Aboriginal and Treaty Rights in Canada: Essays on Law, Equality, and Respect for Difference. Michael Asch (ed.), 75-96. Vancouver: University of British Columbia Press.

Lasky, Jacqueline. 2011. "Indigenism, Anarchism, Feminism: An Emerging Framework for Exploring Post-Imperial Futures" Affinities: A Journal of Radical Theory, Culture, and Action 5, (1): 3-36

Lavoie, Josee G. 2004. "Governed by Contracts: The Development of Indigenous Primary Health Services in Canada, Australia and New Zealand", Journal of Aboriginal Health.1,(1): 6-24

Lawrence, Bonita. 2003. "Gender, Race, and the Regulation of Native Identity in Canada and the United States: An Overview." Hypatia 18, (2): 3-31

Law Commission of Canada. 1998. Needs and Expectations for Redress of Victims of Abuse. Toronto: Law Commission of Canada, 1998.

2000. Restoring Dignity: Responding to Child Abuse in Canadian Institutions. Toronto: Law Commission of Canada.

Lebeuf, Marcel-Eugene. 2011. "Executive Summary" in The Role of the Royal Canadian Mounted Police During the Indian Residential School System. Ottawa: Royal Canadian Mounted Police. <http://www.rcmp-grc.gc.ca/aboriginal-autochtone/irs-spi-eng.htm> 
Legacy of Hope Foundation. 2010. Hope and Healing. Ottawa: Legacy of Hope.

$<$ http://www.legacyofhope.ca/downloads/hope-and-healing.pdf $>$

Leys, Ruth. 2000. Trauma: A Genealogy. Chicago: University of Chicago Press.

Lindroth, Marjo. 2014. "Indigenous Rights as Tactics of Neoliberal Governance: Practices of Expertise in the United Nations" Social and Legal Studies 23, (3): 341-360

Lipsitz, George. 2006. The Possessive Investment in Whiteness: How White People Profit from Identity Politics. Philadelphia: Temple University Press.

Llewellyn, Jennifer. 2003. "Dealing with the Legacy of Native Residential School Abuse in Canada: Litigation, ADR, and Restorative Justice," The University of Toronto Journal of Law 52, 3: 253-300

2008. "Bridging the Gap between Truth and Reconciliation: Restorative and the Indian Residential School Truth and Reconciliation Commission", M. Brant Castellano, L. Archibald, M. DeGagne eds., From Truth to Reconciliation: Transforming the Legacy of Residential Schools, 183-204. Ottawa: Aboriginal Healing Foundation.

Lupton, Deb. 2003. Medicine as Culture. $2^{\text {nd }}$ Ed. London: Sage Publications.

Maaka, Roger and Augie Fleras. 2005. The Politics of Indigeneity: Challenging the State in Canada and Aotearoa New Zealand. Dunedin: University of Otago.

MacDonald, David B. 2015. "Canada's history wars: Indigenous Genocide and Pubic Memory in the United States, Australia and Canada", Journal of Genocide Research 17, (4):411-433.

Mackey, Eva. 1999. The House of Difference: Cultural Politics and National Identity. London: Routledge.

2013. "The Apologizer's Apology," Reconciling Canada: Critical Perspectives in Canada. Jennifer Henderson and Pauline Wakeham (eds), 47-63. Toronto: University of Toronto Press.

------- 2014. 'Unsettling expectations: (un)certainty, settler states of feeling, law, and decolonization', The Canadian Journal of Law and Society 29, (2): 235-252.

Maldonado-Torres, Nelson. 2007. "The Coloniality of Being: On the Development of Concept." Cultural Studies 21, (2-3): 240-270

Mamdani, Mahmood. 2005. "Amnesty or Impunity?: A Preliminary Critique of the Report of the Truth and Reconciliation Commission of South Africa", Diacritics 32, (3-4): 33-59

Marcus, George E. 1995. "Ethnography in/of the World System: The Emergence of Multi-Sited Ethnography." Annual Review of Anthropology 24: 95-117

Martin, Emily. 1994. Flexible bodies: tracking immunity in American culture from the days of polio to the age of AIDS. Boston: Beacon Press.

Martin, Keavy. 2009. "Truth, Reconciliation, and Amnesia: Porcupines and China Dolls and the Canadian Conscience", ESC: English Studies in Canada. 35, (1): 47-65.

Martin, Nick. 2011. "Tears, Flow from U of M apology: First Institution to apologize for role in residential schools" Winnipeg Free Press 28 October 2011

$<$ http://www.winnipegfreepress.com/local/tears-flow-from-u-of-m-apology-132767768.html>

Marx, Karl. 1967. Capital: a critique of political economy. New York: International Publishers.

Matsuda, Mari. 1987. "Looking to the Bottom: Critical Legal Studies and Reparations" Harvard Civil Rights-Civil Liberties Law Review 22: 323-400

Mauss, Mauss. 1954. The Gift: Forms and Functions of Exchange in Archaic Societies. Mansfield Center, CT: Martino Publishing.

McCormick, Rob. 2008. "Aboriginal Approaches to Counselling" Healing Traditions: The Mental Health of Aboriginal Peoples in Canada Laurence J. Kirmayer and Gail Guthrie 
Valaskakis (eds), 337-354. Vancouver and Toronto: University of British Columbia Press, 2010.

McGrath, Carla. 2000. "Using Alternative Dispute Resolution to Respond to Indian Residential School Abuse", Dispute Resolution in Law Studies Award Papers. Canadian Forum on Civil Justice, 1-45. http://www.cfcj-fcjc.org/sites/default/files/docs/hosted/17421-adr residential schools.pdf

McNally, David. 2006. Another World is Possible: Globalization and Anti-Capitalism. Winnipeg: Arbeiter Ring Publishing.

Mental Health Commission of Canada. 2012. Changing Directions, Changing Lives: The Mental Health Strategy of Canada. Toronto: Mental Health Commission of Canada.

Metis National Council. 2013. Metis Residential and Day School Scholars Speak. 6 June 2013

$<$ http://www.metisnation.ca/index.php/news/metis-residential-and-day-school-survivors-speak $>$

Middleton, Elisabeth. 2010. "A Political Ecology of Healing," Journal of Political Ecology

17:1-28< http://jpe.library.arizona.edu/volume_17/Middleton.pdf?>

Mignolo, Walter. 2007. "De-linking: The Rhetoric of Modernity, the Logic of Coloniality and the Grammar of De-coloniality," Cultural Studies 21, (3-4): 449-514

2011. The Darker Side of Western Modernity: Global Futures, Decolonial Options. Durham: Duke University Press.

Miller, J.R. 1996. Shingwauk's Vision: A History of Native Residential Schools. Toronto University of Toronto Press.

Million, Dian. 2009. "Felt Theory: An Indigenous Feminist Approach to Affect and History." Wicazo Sa Review, 24, (2): 53-76.

2013 a. "Trauma, Power and the Therapeutic: Speaking Psychotherapeutic Narratives in an era of Indigenous Human Rights" in Reconciling Canada: Critical Perspectives on the Culture of Redress, Jennifer Henderson and Pauline Wakeham (Eds), 159-180, Toronto: University of Toronto Press.

------------- 2013 b. Therapeutic Nations: Healing in an Age of Indigenous Rights. Tucson: University of Arizona Press 2013.

Milloy, John. 1999. A National Crime: The Canadian Government and the Residential School System, 1879 to 1986. Winnipeg: University of Manitoba Press.

Minow, Martha. 1998. Between Vengeance and Forgiveness: Facing History after Genocide and Mass Violence. Boston: Beacon Press.

Mitchell. Timothy. 2006. "Society, Economy, and the State Effect." The Anthropology of the State, Aradhana Sharma and Akhil Gupta (eds.), 169-186. Malden, MA; Oxford: Blackwell Publishing.

Molema, Arie. 2011. "Manufacturing the Self-Healing Subject: Aboriginal Health Funding in Canada's Era of 'Truth and Reconciliation'" Munk School Briefings, Comparative Program on Health and Society Lupina Foundation Working Paper Series, 2011-2012. http://munkschool.utoronto.ca/cphs/wp-content/uploads/2013/02/Molema-11-12.pdf

Moon, Claire. 2008. Narrating Political Reconciliation: South Africa's Truth and Reconciliation Commission. Plymouth, U.K: Lexington Books.

2009 "Healing Past Violence: Traumatic Assumptions and Therapeutic Interventions in War and Reconciliation”, Journal of Human Rights 8: 71-91.

2012. "Who'll Pay Reparations on My Soul? Compensation, Social Control and Social Suffering”, Social and Legal Studies 21, (2): 1-14. 
Monaghan, Jeff. 2013. "Settler Governmentality and Racializing Surveillance in Canada's North-West", Canadian Journal of Sociology 38, (4): 487-508

Moran, Mayo. 2014. "The role of Reparative Justice in Responding to the Legacy of Indian Residential Schools", The University of Toronto Law Journal 64, (4): 529-565

Moreton-Robinson, Aileen. 2007. "Writing Off Indigenous Sovereignty: The discourse of Security and Patriarchal White Sovereignty", Sovereign Subjects: Indigenous Sovereignty Matters, Aileen Moreton-Robinson (ed), 86-105. Crow's Nest: Allen and Unwin.

Pathology of Patriarchial White Sovereignty", Cultural Studies Review 15, (2): 61-79.

Morrissette, Patrick and Alanaise Goodwill. 2013. "The Psychological Cost of Restitution: Supportive Intervention with Canadian Indian Residential School Survivors", Journal of Aggression, Maltreatment \& Trauma 22, (5): 541-558

Mosby, Ian. 2013. "Administering Colonial Science Nutrition Research and Human Biomedical Experimentation in Aboriginal Communities and Residential Schools, 1942-1952", Histoire sociale/Social history. 46, (91): 145-172

Moses, A. Dirk. 2004. "Genocide and the settler society in Australian History", Genocide and Settler society: Frontier Violence and Stolen Indigenous Children in Australian History A. Dirk Moses (ed.)., 3-49 New York; Oxford: Bergahan Books.

Moten, Fred and Stefano Harney. 2012. "Debt and Study" E-Flux Journal.

$<$ http://www.e-flux.com/journal/debt-and-study/>

Nagy, Rosemary. 2012. "The Scope and Bounds of Transitional Justice and the Canadian Truth and Reconciliation Commission", The International Journal of Transitional Justice 7, (1): $52-73$.

-----------. 2014. "The Truth and Reconciliation Commission of Canada: Genesis and Design", Canadian Journal of Law and Society 29, (2): 199-217.

-------------. 2015. “Truth, Trauma, Agency”, International Journal of Transitional Justice, 9, (3): $527-538$

Narine, Shari. 2013. "Judge dismisses Métis residential students' class-action lawsuit" Windspeaker 9, (31): no pagination.

$<$ http://www.ammsa.com/publications/saskatchewan-sage/judge-dismisses-m\%C3\%A9tisresidential-students\%E2\%80\%99-class-action-lawsuit\#sthash.Udh8ZNQq.dpuf>

Nadar, Laura. 1990. Harmony Ideology: Justice and Control in a Zapotec mountain village. Stanford Calif.: Stanford University Press.

-------------.2003. “Departures from Violence: Love is not Enough”, Public Culture 15, (1): 195 $-197$.

Nadasdy, Paul. 2003. Hunters and Bureaucrats: Power, Knowledge, and Aboriginal-state Relations in the Southwest Yukon. Vancouver; Toronto: University of British Columbia Press.

National Native Addictions Partnerships Foundation. 2012. Honouring Our Strengths: A Renewed Framework to Address Substance Abuse Issues among First Nations People in Canada, Ottawa: National Native Addictions Partnerships Foundation

National Residential School Survivors' Society. A Preliminary Report Regarding the Implementation of the Indian Residential School Settlement Agreement. $3^{\text {rd }}$ Draft 12 November 2007.

Nelson, Diane M. 2010. "Reckoning the After/math of War in Guatemala", Anthropological Theory 10, (1-2): 87-95 
2015. Who Counts?: The Mathematics of Death and Life after Genocide. Durham and London: Duke University Press.

Nelson, Sarah. 2012. "Challenging Hidden Assumptions: Colonial Norms as Determinants of Aboriginal Mental Health," National Collaborating Centre for Aboriginal Health.

$<$ http://www.nccah-

ccnsa.ca/Publications/Lists/Publications/Attachments/70/colonial_norms_EN_web.pdf>

Neu, Dean. 2000 a. "Accounting and Accountability Relations: Colonization, Genocide and Canada's First Nations" Accounting, Auditing and Accountability, Vol. 13, (1): 268-288.

---- 2000 b. "'Presents' for the 'Indians': Land, Colonialism and Accounting in Canada", Accounting, Organizations and Society 25, (2): 163-184.

Neu, Dean and Richard Therrien. 2003. Accounting for Genocide: Canada's Bureaucratic Assault on Aboriginal People. Winnipeg: Fernwood Books.

Neu, Dean and Monica Heincke. 2004. "The Subaltern Speaks: Financial Relations and the Limits of Governmentality", Critical Perspectives on Accounting. 15, (1): 179-206.

Niezen, Ronald. 2013. Truth and Indignation: Canada's Truth and Reconciliation Commission on Indian Residential Schools. Toronto: University of Toronto Press.

Nolan, James. 1998. The Therapeutic State: Justifying Government at Century's End. New York and London: Ney York University Press.

O’Malley, Pat. 2006. "Risk and restorative justice: governing through the democratic minimization of harms. In Institutionalizing Restorative Justice, Ivo Aertsen, Tom Daems and Luc Robert (Eds.), 216-236. UK: Willan Publishing.

Office of the Auditor General of Canada. 1998. "Chapter 14: Indian and Northern Affairs Canada Comprehensive Land Claims", 1998 September Report of the Auditor General of Canada. Ottawa: Minister of Public Works and Services.

-2011. "Chapter 4: Programs on First Nations Communities," 2011 Report of the Office of the Auditor General. Ottawa: Minister of Public Works and Services.

--------. 2013. "Chapter 6: Creating a Historical Record of Indian Residential Schools", 2013 Report of the Office of the Auditor General. Ottawa: Minister of Public Works and Services.

Office of the Minister of Aboriginal Affairs and Northern Development. 2012. Address to the Crown-First Nations Gathering. January 242012.

2012. Speech delivered by Honourable John Duncan, PC, MP Minister of Aboriginal Affairs and Northern Development Calgary Chamber of Commerce, Aboriginal-Business Connection Series Calgary, Alberta, March 20

$<$ https://www.aadnc-aandc.gc.ca/eng/1332427340050/1332427397185>

--------. 2012. Regina Chamber of Commerce. Notes for an address by the Honourable John Duncan, PC, MP Minister of Aboriginal Affairs and Northern Development. August 2

$<$ https://www.aadnc-aandc.gc.ca/eng/1344015218110/1344015276952> Honourable John Duncan, PC, MP, Minister of Aboriginal Affairs and Northern Development Sept. 11

$<$ https://www.aadnc-aandc.gc.ca/eng/1347459538949/1347459567923

Treaties" Symposium 7 Oct 2013

$<$ http://www.aadnc-aandc.gc.ca/eng/1381156885861/1381156990723> 
Ontario Disability Support Program. "Eligibility”. Toronto: Ministry of Community and Social Affairs.

http://www.mcss.gov.on.ca/en/mcss/programs/social/odsp/income_support/IS Eligibility.aspx

Opekokew, Delia. 1987. The Political and Legal Inequities among Aboriginal Peoples in Canada. Kingston: Institute of Intergovernmental Relations.

Orsini, Michael. 2007. 'Discourses in Distress: from 'Health Promotion' to 'Population Health' to 'you are responsible for your own health'”, Critical Policy Studies, Miriam Smith and Michael Orsini (eds), 347-367. Vancouver: University of British Columbia Press.

Oxford English Dictionary. "Investment", available at www.oed.com

Quijano, Anibal. 2000. "Coloniality of Power and Eurocentrism in Latin America," International Sociology 15 (2): 215-232

Park, Augustine. 2015. "Settler Colonialism and the Politics of Grief: Theorising a Decolonising Transitional Justice for Indian Residential Schools", Human Rights Review. Vol. 16, (3): 273-293

Pasternak, Shiri 2014. Jurisdiction and Settler Colonialism: The Algonquins of Barriere Lake against the Federal Land Claims Policy. Unpublished Dissertation. Toronto: Department of Geography, University of Toronto.

Peck, Jamie and Adam Ticknell. 2002. "Neoliberalizing Space” Antipode 34 (3): 380-404

Petoukhov, Konstantin. 2011. "Locating a Theoretical Framework for the Canadian Truth and Reconciliation Commission: Charles Taylor or Nancy Fraser?" International Indigenous Policy Journal 3, (2): 1-18.

Popic, Linda. 2007/2008. “Compensating Canada's 'Stolen Generations' Indigenous Law Bulletin 7, (2): 14-18

Power, Michael. 1997. The Audit Society: Rituals of Verification. Oxford: Oxford University Press. Auditing 4: 111-119.

Prentice, Jim (Hon). "Getting to 'Yes': Aboriginal Canadians and the Next Wave of Nation Building in Canada" Presentation made to the Assembly of First Nations in Whitehorse, YK 16 July 2013.

$<$ https://www.cibc.com/ca/pdf/investor/afn-distribution-july16-en.pdf $>$

Preston, Jen. 2013. Neoliberal Settler Colonialism, Canada and the Tar Sands", Race and Class 55, 2: 42-59.

Proceedings of the Standing Senate Committee on Social Affairs, Science and Technology. Issue 23 Evidence June 21, 2005

Proceedings of the Standing Senate Committee on Social Affairs, Science and Technology. Issue 27 Evidence September 20, 2005.

Proceedings of the Standing Parliamentary Committee on Aboriginal Affairs and Northern Development. 2007. Evidence 20 March 2007, 39 ${ }^{\text {th }}$ Parliament, $1^{\text {st }}$ Session. -.2008. Evidence April 2008, 39 $9^{\text {th }}$ Parliament, 1rst Session.

Proceedings of the Parliament of Canada. 2010. "Emergency Debate: Closure of Aboriginal Healing Foundation." April 30 30 th 2010.

Public Health Agency. 2012. "What is the Population Health Approach?” Ottawa: Health Canada $<$ http://www.phac-aspc.gc.ca/ph-sp/approach-approche/index-eng.php $>$ Last Updated 2012-02-07 
Public Policy Forum. 2012. Building Authentic Partnerships: Aboriginal Participation in Major Resource Development Opportunities. Ottawa: Public Policy Forum.

Puar, Jasmine. 2012. "Coda: The Cost of Getting Better: Suicide, Sensation, Switchpoints" GLQ 18, (1): 149-58.

Quijano, Anibal. 2000. “Coloniality of Power and Eurocentrism in Latin America.” International Sociology 15, (2): 215-232.

Razack, Sherene. 2002. Race, Space and Law: Unmapping a White Settler society. Toronto: Between the Lines.

----------. 2014. “'It Happened More than Once: Freezing Deaths in Saskatchewan”, Canadian Journal of Women and the Law 26, (1): 51-80

Rifkin, Mark. 2009. Manifesting America: The Imperial Construction of U.S. National Space. Oxford: Oxford University Press.

2011. "Settler States of Feeling: National Belonging and the Erasure of Native American Presence" Caroline Levander and Robert Levine (eds), 342-355. A Companion to American Literary Studies. Malden, MA: Blackwell Publishing.

---------. 2013. "Settler common sense” Settler Colonial Studies. 3, (3-4): 322-340

Regan, Paulette. 2010. Unsettling the settler within: Indian residential schools, truth telling, and Reconciliation in Canada. Vancouver: University of British Columbia Press.

Rivers, Khelsilem. 2013. "Big Oil Funds Reconciliation in Vancouver", Intercontinental Cry Magazine 11 Sept 2013.

Roach, Kent. 2014. "Blaming the Victim: Canadian Law, Causation, and Residential Schools", University of Toronto Law Journal, 64, (4): 566-595

Roberson, L.H. 2006. "The Residential School Experience: Syndrome or Historic Trauma", Pimatisiwin 4, (1): 1-28

Robbins, Julian A. and Jonathan Dewar. 2011. "Traditional Indigenous Approaches to Healing and the modern welfare of Traditional Knowledge, Spirituality and Lands: A Critical Reflection on Practices and Policies taken from the Canadian Indigenous Example", The International Indigenous Policy Journal 2, (4): 1-17.

Roblin-Ghanie, Maya. 2010. "Healing Denied: Native-run Healing Centres Forced to Close", Briarpatch Magazine. Regina. 9 Sept 2010.

Rose, Nikolas. 1999. Powers of Freedom: Reframing Political Thought. Cambridge U.K; New York, NY: Cambridge University Press.

Ross, Fiona. "On having voice and being heard some after-effects of testifying before the South African Truth and Reconciliation Commission", Anthropological Theory 3 (3): 325-341.

Ross, Rupert. 2006. Returning to the Teachings: Exploring Aboriginal Justice. Toronto: Penguin Canada.

Royal Bank of Canada. 2013. A Chosen Journey: RBC Aboriginal Partnership Report. Toronto: Royal Bank of Canada.

$<$ http://www.rbcroyalbank.com/commercial/aboriginal/pdf/57482\%20Aboriginal\%20Report_E.p df $>$

Royal Canadian Mounted Police. 2011. The Role of the Royal Canadian Mounted Police during the Residential School System. Ottawa: Royal Canadian Mounted Police.

Royal Canadian Mounted Police. 2014. "Strategic Priority: Aboriginal Communities" Ottawa: Royal Canadian Mounted Police.

$<$ http://www.rcmp-grc.gc.ca/aboriginal autochtone/prior-eng.htm> 
Royal Commission on Aboriginal Peoples. 1992. Towards Reconciliation. Ottawa: Supply and Services Canada 1993. Path to Healing: report of the National Round Table on Aboriginal Health and Social Issues. Ottawa: Supply and Services Canada Relationship. Ottawa: Supply and Services Canada.

996. Final Report Volume 2: Restructuring the 1996. "Health and Healing," Final Report Volume 3: Gathering Strength. Ottawa: Supply and Services Canada. -1996. People to People: Nation to Nation: Highlights on the Royal Commission of Aboriginal People. Ottawa: Canada Publishing Group. 1996. Final Report Volume 5: Renewal A Twenty Year Commitment. Ottawa: Supply and Services Canada.

Rymhs, Deena. 2006. "Appropriating Guilt: Reconciliation in an Aboriginal Context", ESC: English Studies in Canada 32, (1): 105-123.

Samson, Colin and Elizabeth Cassell. 2013. 'The Long Reach of Frontier Justice: Canadian Land Claims "Negotiation" Strategies as Human Rights Violations', International Journal of Human Rights 17, (1), 2013: 35-55.

Samson, Colin. 2014. "Dispossession and Canadian Land Claims: Genocidal implications of the Innu Nation Land claim" in Colonial Genocide in Indigenous North America, Andrew Woolford, Jeff Benvenuto and Alexander Laban Hinton (eds), 246-270. Durham: Duke University Press.

Saragiacomo, Massimo et al., 2014. 'Accounting for natural disasters and humanitarian intervention', Critical Perspectives on Accounting 25, (7): 576-58.

Saukko, Paula. 2003. Doing Research in Cultural Studies: An Introduction to Classical and New Methodological Approaches. London; Thousand Oaks, Calif.: Sage Publishers.

Schwab, Gabriele. "Writing against Memory and Forgetting", Literature and Medicine 25, (1): 95 $-121$

Sennett, Richard and Johnathan Cobb. 1972. The Hidden Injuries of Class. London: Billings and Sons Ltd.

Scott, James C. 1998. Seeing like a State: How Certain Schemes to Improve the Human Condition have Failed. New Haven and London: Yale University Press.

Shamir, Ronen. 2008. "The Age of Responsibilization: On Market-Embedded Morality", Economy and Society 37, (1): 1-19.

Shore, Cris and Susan Wright. 1997. "Policy: A new field in Anthropology", The Anthropology of Policy: Critical Perspectives on Governance and Power, 3-33. London and New York: Routledge Publishers.

-- 2000. "Coercive Accountability" in Audit Cultures: Anthropological Studies in Accountability, Ethics and the Academy. Marilyn Strathern (ed.), 57-89. London and New York: Routledge Books.

Short, Damien. 2005. "Reconciliation and the Problem of Internal Colonialism", Intercultural Studies 26, (3): 267-282.

Simpson, Leanne. 2011. Dancing on Our Turtle's Back: Stories of Nishnaabeg Re-creation, Resurgence and a new Emergence. Winnipeg: Arbeiter Ring Publishing.

Sinclair, Justice Murray. 2012. "Address at the July 2012 Assembly of First Nations AGA, Winnipeg Manitoba", Winnipeg: July 24 2012. (Accessed through webcast and transcribed by Robyn Green). 
Smith, Andrea. 2010. "Queer Theory and Native Studies: The Heteronormativity of Settler Colonialism", GLQ: A Journal of Lesbian and Gay Studies 16, (1-2): 42-68.

Spade, Dean. 2011. Normal Life: Administrative Violence: Critical Trans Politics and the Limits of the Law. New York: South End Press.

Spear, Wayne K. Full Circle: The Aboriginal Healing Foundation and the Unfinished Work of Hope, Healing and Reconciliation. Ottawa: Aboriginal Healing Foundation.

Stanton, Kim. 2010. "Canada's Truth and Reconciliation Commission: Settling the Past?" Indigenous Policy Journal. 2, (3): 1-18

Statistics Canada. 2006. "Employment," Aboriginal Statistics at a Glance, 2006.

$<$ http://www.statcan.gc.ca/pub/89-645-x/2010001/employment-emploi-eng.htm>

Stimson, Adrian. 2009. "Used and Abused", Kennedy, Roseanne, Lynne Bell and Julia Emberley (Eds), Special Issue: Decolonising testimony: on the possibilities and limits of witnessing Humanities Research 15, (3): 71-80

Stoesz, David. 2000. A Poverty of Imagination: Bootstrap Capitalism, Sequel to Welfare Reform. Madison: The University of Wisconsin Press.

Strathern, Marilyn. 2000. Audit Cultures: Anthropological Studies in Accountability, Ethics and the Academy. London and New York: Routledge Books.

Tal, Kali. 1996. Worlds of Hurt: Reading the Literatures of Trauma. Cambridge: Cambridge University Press.

Thielen-Wilson L. 2012. White Terror, Canada's Indian Residential Schools and the Colonial Present: From Law towards a Pedagogy of Recognition. Unpublished Dissertation. Toronto: University of Toronto.

Thobani, Sunera. 2007. Exalted Subjects: Studies in the Making of Race and Nation. Toronto: University of Toronto Press.

Tomiak, Julie-Ann. 2011. Indigenous Self-Determination, Neoliberalization, and the Right to the City: Rescaling Aboriginal Governance in Ottawa and Winnipeg. Unpublished Dissertation. Ottawa: School of Canadian Studies, Carleton University.

Torpey, John. 2006. Making Whole What Has Been Smashed: On Reparation Politics. Cambridge and London: Harvard University Press.

Trigo, Antonio, Fernando Belfo and Raquel Pérez Estébanez. 2014. "Accounting Information Systems: The Challenge of Real-Time Reporting", Procedia Technology 16: 188-27.

Troniak, Shauna. 2011. Addressing the Legacy of Residential Schools. Ottawa: Library of Parliament Social Affairs Division.

Tsing, Anna. 2005. Friction: An Ethnography of Global Connection. Princeton: Princeton University Press.

Truth and Reconciliation Commission of Canada. Missing Children and Unmarked Burials: Research Project

$<$ http://www.trc.ca/websites/trcinstitution/File/pdfs/Working_group_on_Mis_7456E0.pdf $>$

. "Bentwood Box arrives at TRC" Winnipeg: Truth and Reconciliation Commission of Canada. $<$ http://www.trc.ca/websites/trcinstitution/index.php?p=42> . "Expressions of Reconciliation" Winnipeg: Truth and Reconciliation Commission of Canada. http://www.trc.ca/websites/reconciliation/index.php? $\mathrm{p}=348$ Winnipeg: Truth and Reconciliation Commission of Canada.

Winnipeg: Truth and Reconciliation Commission of Canada. 
2011 b. "Concept Paper: Atlantic National Event". Winnipeg: Truth and Reconciliation Commission of Canada.

.--. 2012. Truth and Reconciliation Commission of Canada: Interim Report. Winnipeg: Truth and Reconciliation Commission of Canada.

--onsts: Saskatoon National Event, June 21-24, 2016", Winnipeg: Truth and Reconciliation Commission of Canada.

2013. Quebec National Event, April 24-27, 2013 Program. Winnipeg:

Truth and Reconciliation Commission of Canada.

2015. Truth and Reconciliation Commission of Canada: Final Report.

Winnipeg: Truth and Reconciliation Commission of Canada.

Tuck, Eve. 2009. "Suspending Damage: A Letter to Communities", Harvard Educational Review $79,(3): 409-427$.

Tuck, Eve and Wayne Yang. 2012. "Decolonization is not a Metaphor", Decolonization: Indigeneity, Education and Society 1, (1): 1-40

Turner, Dale. 2006. This is not a peace pipe: towards critical Indigenous philosophy. Toronto: University of Toronto.

---on 2013. “On the Idea of Reconciliation”, in Jennifer Henderson and Pauline Wakeham (eds). Reconciling Canada: Critical Perspectives on the Culture of Redress. Toronto: University of Toronto Press.

Union of British Columbia Indian Chiefs. "Certainty: Canada's Struggle to Extinguish Aboriginal Title". <http://www.ubcic.bc.ca/Resources/certainty.htm\#axzz480EPxvK0>

University of Manitoba. 2013. "Strategic Planning Framework: Aboriginal Achievement", Winnipeg: University of Manitoba

$<$ http://umanitoba.ca/admin/president/strategic_plan/2295.html>

Ventura, Patricia. 2012. Understanding Neoliberal Culture: Living with American Neoliberalism. Surrey, U.K.: Ashgate Publishing Ltd.

Vrastri, Wanda. 2013. "“Caring' Capitalism and the Duplicity of Critique”, Theory and Event 14, (4): no pagination.

Wadden, Marie. 2008. Where the Pavement Ends. Vancouver/Toronto: Douglas\& McIntyre.

Walker, Julien. 2009. The Indian Residential School Truth and Reconciliation Commission. Ottawa: Parliamentary Information and Research Service.

Washuta, Elissa. 2014. “This Indian Does Not Owe You”, BuzzFeedNews. 22 Sept 2014. $<$ https://www.buzzfeed.com/elissawashuta/this-indian-does-not-owe-

you?utm_term=.vw2141Y4\#.llqO5OV5>

Waslander, Bert. 1997. "Government Expenditures on Aboriginal People: The Costly Status Quo", Canadian Tax Journal 45, 5: 959-978.

Wente, Margaret. 2008. "Whose truth? What reconciliation?" The Globe and Mail. 12 June 2008.

$<\mathrm{http} / / / \mathrm{www} \cdot$ theglobeandmail.com/news/national/whose-truth-what-

reconciliation/article720209/>

Wesley-Esquimaux, Cynthia and Magdalena Smolewski. 2004. Historic Trauma and Aboriginal Healing. Ottawa: Aboriginal Healing Foundation.

Wexler, David. 2005. "Therapeutic Jurisprudence: An Overview," Thomas M. Cooley Law Review 17: 125-134

Wherry, Aaron. The Commons: Way to go, Skippy. MacLean's Magazine. 12 June 2006. $<$ http://www2.macleans.ca/2008/06/12/the-commons-way-to-go-skippy-2/> 
Widdowson, Frances. "The Aboriginal Healing Boondoggle" The National Post. 2 January 2010, A5

Williams, Fiona. 2012. "Care relations and public policy: social justice claims and social investment frames," Families, Relationships and Societies 1, (1): 103-19

Winter, Stephen. 2011. "Legitimacy, Citizenship and State Redress" Citizenship Studies 15, (6-7): $794-811$

Wolch, Jennifer. 1989. "The Shadow State: Transformation in the Voluntary Sector" in Power of Geography: How Territory Shapes Social Life in Jennifer Wolch and Michael Dear (eds.), 197-221. New York: Routledge Ltd.

Wolfe, Patrick. 2006. "Settler Colonialism and the Elimination of the Native." Journal of Genocide Research. 8, (4): 387-409

Woodward, Kathleen. 2009. Statistical Panic: Cultural politics and poetics of the emotions. Durham: Duke University Press.

Woolford, Andrew. 2004. "Negotiating Affirmative Repair: Symbolic Violence in the British Columbia Treaty Process." The Canadian Journal of Sociology 29, (1): 111-144.

-.-- 2005. "Ontological Destruction: Genocide and Aboriginal Peoples in Canada." Genocide Studies and Prevention 4, (1): 81-97.

Woolford, Andrew and R.S. Ratner. 2003. Nomadic Justice?: Restorative Justice on the Margins of Law", Social Justice 30, (1): 177-194

----onfortict Resolution in Median, Restorative Justice and Reparations. New York: Routledge-Cavendish.

Woolford, Andrew and Jeff Buenevento. 2015. "Canada and Colonial Genocide", Journal of Genocide Research, 17, (4): 373-391.

Wotherspoon, Terry and Victor Satzewich. 2001. First Nations: Race, Class and Gender Relations. Regina: Canadian Plains Research Centre. (Reprint) 